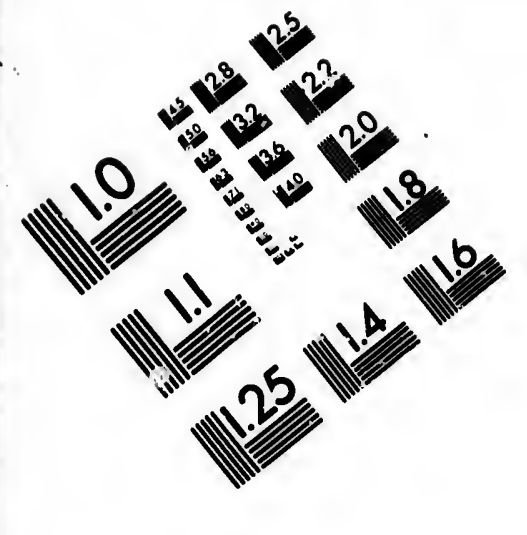

IMAGE EVALUATION

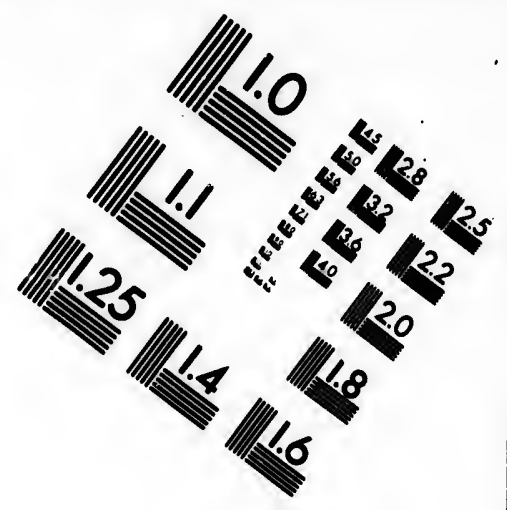

TEST TARGET (MT-3)
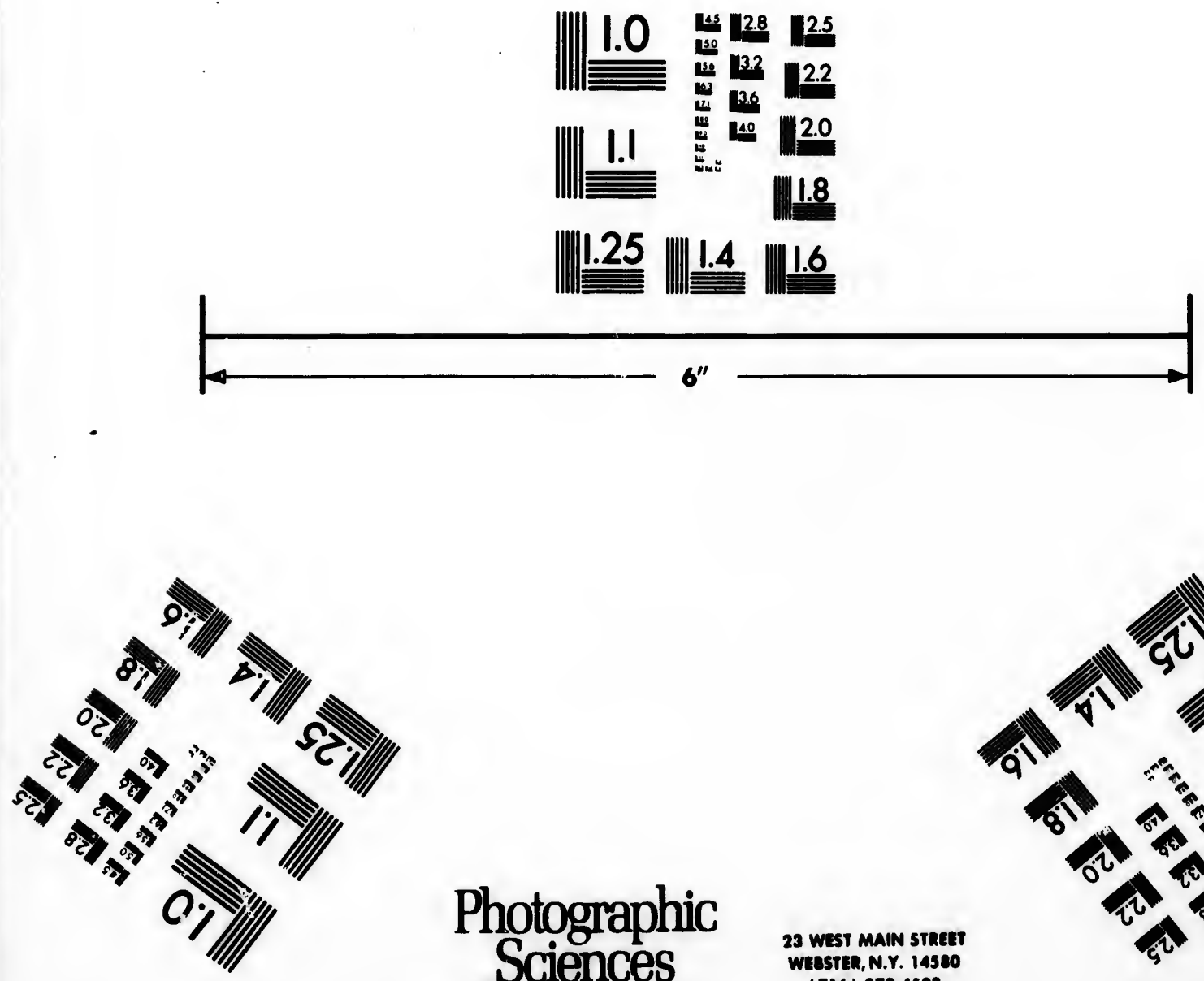

Photographic Corporation

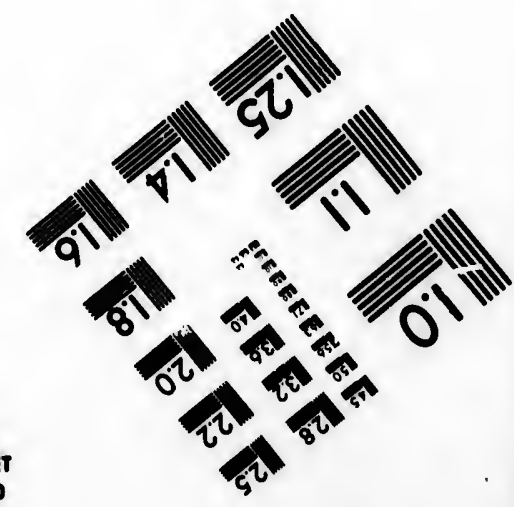




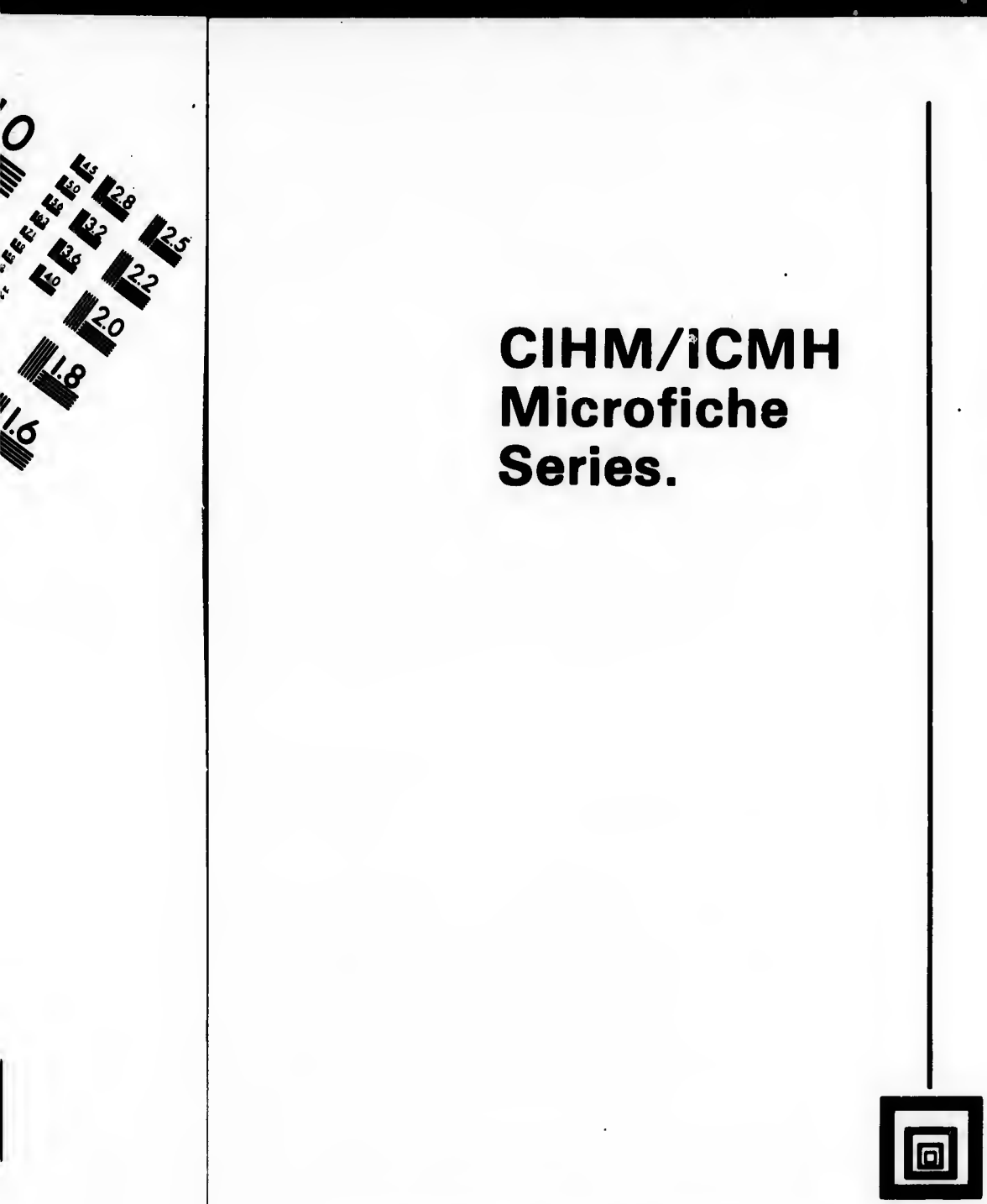

Canadian Institute for Historical Microreproductions / Institut canadien de microreproductions historiques
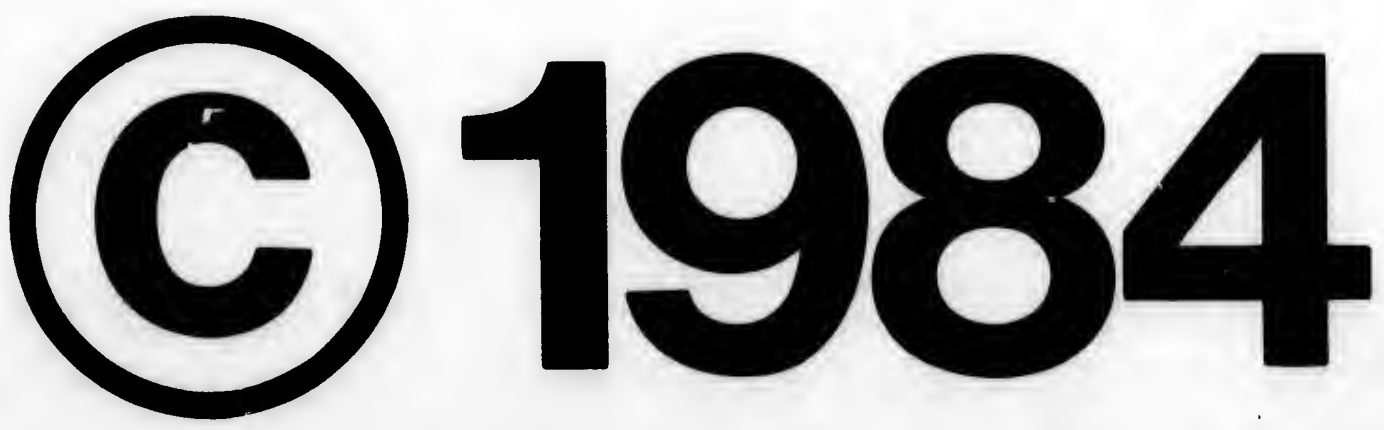
The Institute has attempted to obtain the best original copy avallable for filming. Features of this copy which may be bibliogrephically unique. which may alter any of the images in the reproduction, or which may signiflcantly change the usual method of filming, are checked below.

Coloured covers/

Couverture de couleur

Covers damaged/

Couverture endommagée

Covers restored and/or laminated/

Couverture restaurbe et/ou pelliculce

Cover title missing/

Le titre de couverture manque

Coloured mapa/

Cartes gbographiques en couleur

Coloured ink (i.e. other than blue or black)/

Encre de couleur (i.e. autre que bleue ou noire)

Coloured plates and/or illustrations/

Planches et/ou illustrations en couleur

Bound with other material/

Relis avec d'autres documents

Tight binding may cause shadows or distortion atong interior margin/

La reliure serrée peut causer de l'ombre ou de la distortion le long de la marge intérioure

Blank leaves added during restoration may appear within the text. Whenever possible, these have been omitted from filming/

II se peut que certaines pages blanches ajoutces lors d'une restauration apparoissent dans le texte, mais. lorsque cela stait possible, ces peges n'ont pas ete filmeses.

Additional comments:/

Commentaires supplómentaires:
L'Institut a microfilmb lo molllour exemplaire qu'll lui a etó posalble de se procuror, Les dótails de cet exemplalre qui sont pout-stre uniques du point de vus blbllographlque, qul pouvent modifier une image reproduite, ou qul peuvent exiger une modification dens la muthodo normale de filmage sont indiquos cl-dossous.

Coloured payed

Pages do coulour

Pages damagod/

Pages endommageses

Pages restored and/or laminated/

Pages restaurces ot/ou pelliculies

Pages discoloured, stained or foxed/

Pages dícolorkes, techotbes ou piqudes

\section{Pages dotechod/}

Pages dótachios

Showthrough/

Treneparence

Quality of print varies/

Qualite Incoale do I'Impression

Includos supplomentory matorial/

Comprend du matórlel supplémentaire

Only edition avellable/

Soule Gdition disponible

Pages wholly or partlally obscured by errata elips, tisesues, otc., have been rofilmed to ensure the beot posalble image/

Les pages totaloment ou partiallement obscurcies par un foulllet d'errata, une pelure. etc., ont bté fllimbes nouveau de façon a obtenir le mollleure image posalble.

This item is filmed at the reduction ratio chocked bolow/ Ce documsnt est fllmé au taux de réduction indique cl-dossous.

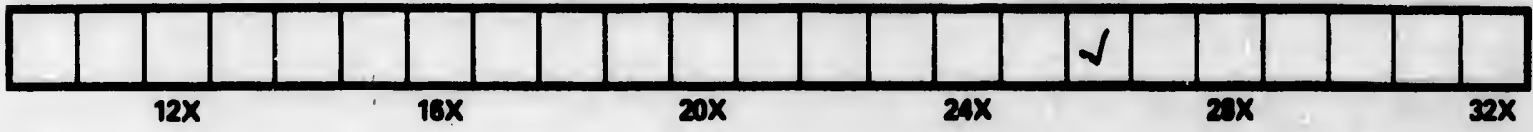


The copy filmed here has been reproduced thanks to the generoolty of:

University of British Columbia Library

The imeges appearing hare are the beat quality poselble conoldoring the condition and logibility of the original copy and in keoping with the filming contract apecifications.

Original coples in printed papar covers are filmod boginning with the front cover and ending on the last pege with a printed or llluatrated impreeslon, or the beck cover when eppropriate. All other original copice are filmed beginning on the firot peos with a printed or illustrated Impres. alon, and ending on the last page with a printed or llilustrated impresaion.

The laat recorded frame on each microfiche shall contain the symbol $\rightarrow$ Imoaning "CONTINUED"), or the aymbol $\nabla$ (meaning "END"). whichover applies.

Mape, plates, charts, otc., may bo filmed at different reduction ratios. Those too large to be ontirely included in one exposure are filmed beginning in the upper loft hand cornor, loft to right and top to bottom, as many frames as required. The following dlagrems illustrote the mochod:
L'oxomplaire fllms fut reproduit iortee $t$ ia óncrosito do:

Univarsity of British Columbia Library

Lee imagee sulvantes ont bth reproduitee avec is plus grand soln, compto tenu do la condition ot do le nottots de l'exemplaire filmb. ot en conformits avec les conditions du contrat de filmage.

Les exomplaires originaux dont la couverture on papier eat imprimco sont filmce on commencant par lo premier plat ot on torminant solt par la dernibre page qui comporte une empreinte d'impression ou d'illustration, solt par le second plat, selon lo ces. Tous les autres exemplairee originaux sont filmbe on commoncant per la promidre page quil comporte une ampreinte d'Impression ou d'illustration ot on torminant par la dornidere page qui comporte une telle emprointe.

Un des aymboles suivante apparaitre sur la dernierre image do chaque microficho, selon lo cas: lo oymbolt $\rightarrow$ signifia "A SUIVRE", lo symbole $\nabla$ signifie "FIN".

Les c эrtes, plenches, tableaux, etc. pouvent otre filmbe \& des toux do réduction differents. Loreque lo document est trop grend pour stre reproduit on un eoul clichb, il eat filmb a partir de l'angle suporiour gauche, do gauche d droite. ot do haut on bas. en pronant lo nombre d'images nocesesire. Lee diagrammes suivants lllustront le muthode.
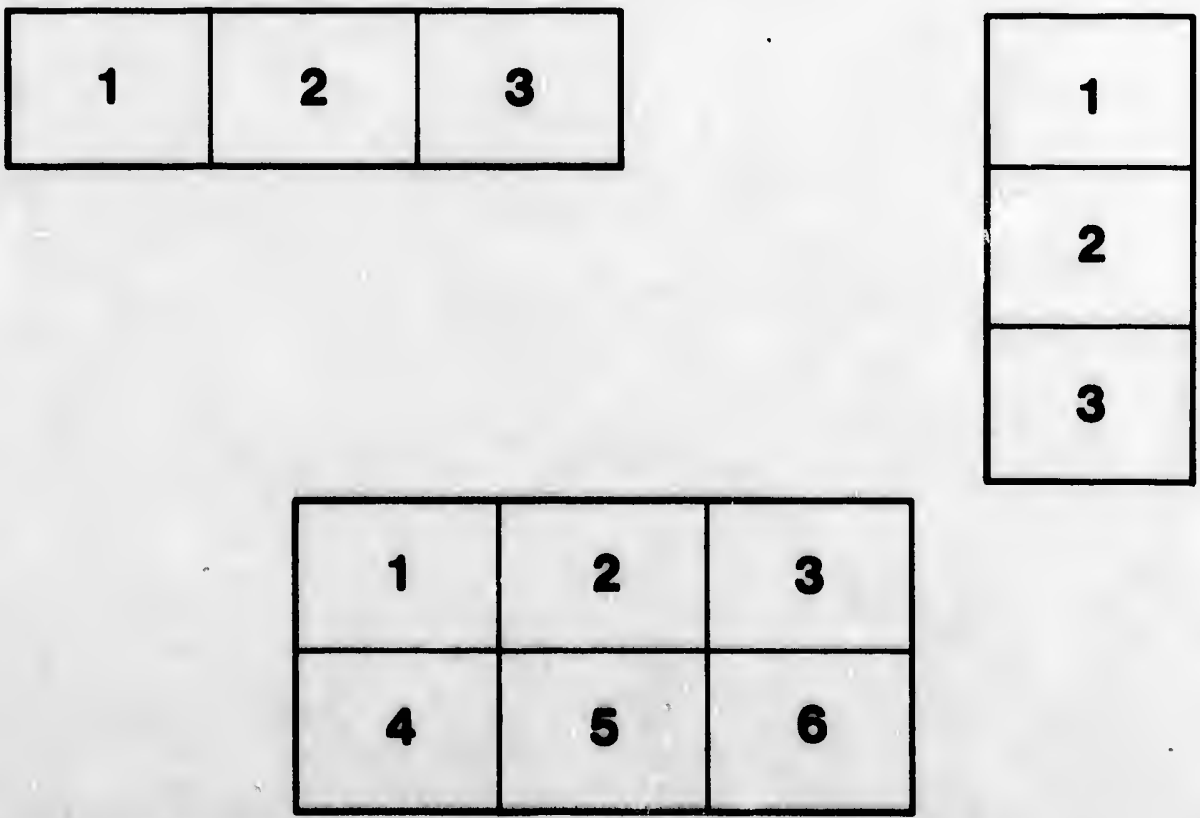


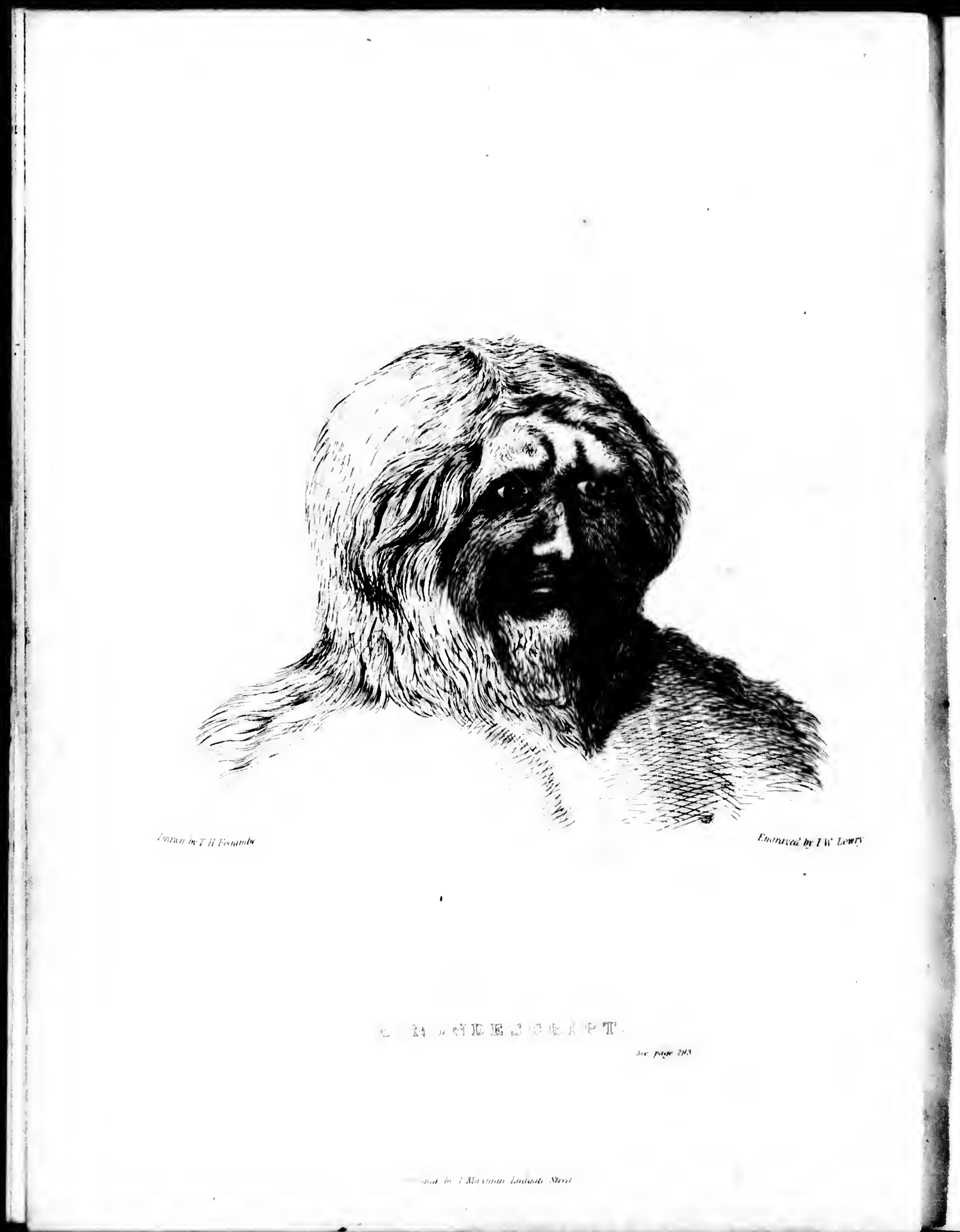




\title{
WANDERINGS
}

\author{
IN \\ SOUTH AMERICA, \\ THE

\section{NORTH-WEST OF THE UNITED STATES,}

\section{And the antilles,}

IN THE YLARS 1812, 1816, 1820, AND 1824.

WITH ORIGINAL INSTRUCTIONS FOR THE PIRFECT PRESERVATION OF BIRDS, \&c. FOR CABINETS UF NATURAL HISTORY.

BY CHARLES WATERTON, ESQ.

LONDON :

PRINTED FOR J. MAWMAN, LUDGATE-STREET.

1825. 


\section{P R E F A C E.}

I OFFE R this book of " Wanderings" with a hesitating hand. It has little merit, and must make its way through the world as well as it can. It will receive many a jostle as it goes along, and perhapsis destined to addone more to the number of slain, in the field of modern criticism. But if it fall, it may still, in death, be useful to me; for should some accidental rover take it up, and, in turning over its pages, imbibe the idea of going out to explore Guiana, in order to give the world an enlarged description of that noble country, I shall say, " fortem ad fortia misi," and demand the armour; that is, I shall lay claim to a certain portion of the honours he will receive, upon the plea, that $I$ was the first mover of his discoveries; for, as Ulysses sent Achilles to Troy, so I sent him to Guiana. I intended 
to have written much more at length ; but days, and months, and years have passed away, and nothing has been done. Thinking it very probable that I shall never have patience enough to sit down and write a full account of all 1 saw and examined in those remote wilds, I give up the intention of doing so, and send forth this account of my "Wanderings," just as it was written at the time.

If critics are displeased with it in its present form, I beg to observe, that it is not totally clevoid of interest, and that it contains something useful. Several of the unfortunate gentlemen who went out to explore the Congo, were thankful for the instructions they found in it; and Sir Joseph Banks, on sending back the journal, said in his letter, "I return your journal, with abundant thanks for the very instructive lesson you have favoured us with this morning, which far excelled, in real utility, every thing I have hitherto seen." And in another letter he says, "I hear with particular pleasure your intention of resuming your 
interesting travels, to which natural history has already been so much indebted." And again, "I am sorry you did not deposit some part of your last harvest of birds in the British Museum, that your name might become familiar to naturalists, and your unrivalled skill in preserving birds, be made known to the public." And again, " You certainly have talents to set forth a book, which will improve and extend materially the bounds of natural science."

Sir Joseph never read the third adventure. Whilst I was engaged in it, death robbed England of one of her most valuable subjects, and cleprived the Royal Society of its brightest ornament. 


\section{WA NDER I N G S}

\section{IN \\ S O U T H A M E R I CA.}

" nec herba, nec latens in asperis
Radix fefellit me locis."

$I_{N}$ the month of April, 1812, I left the town of Stabroek, Finst to travel through the wilds of Demerara and Essecpuibo, Jovasex. a part of ci-der'ant Dutch Guiana, in South America.

The chief objects in view, were to collect a quantity of Its object. the strongest Wourali poison; and to reach the inland frontier fort of Portugnese Guiana.

It would be a tedious journey for him who wishes to travel through these wilds, to set out from Stabroek on foot. The sun would exhaust him in his attempts to wade through the swamps; and the mosquitos at night would deprive him of every hour of sleep. 


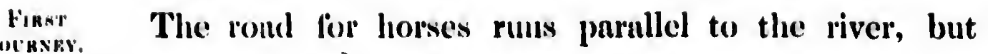
Joenses. it cxteuds "very little way, and even ends before the cultivation of the phuntutions censes.

The only mode then that remuins, is to proceed by writer; and when you come to the high lunds, you muy mulic your why through the forest on foot, or continue your route on the river.

line of the

After pussing the third island in the river Demerarn, there ure few phuntatious to be seen, and those not joining on to onc another, but sepurited by lurge tricts of wood.

The Loo is the lust where the sugar-eme is growing. The grenter part of its negroes have just been ordered to another estute; and cre a few months shall have clapsed, all signs of eultivation will be lost in underwood.

Higher up stand the sugar-works of Amelin's Wanrd, solitary and abaudoned! and after passing these, there is not a ruin to inform the traveller, that either coffec or sugar have ever been cultivuted.

From Amelia's Wuard, an umbroken range of forest covers ench bank of the river, saving here and there where a hut discovers itself, inhabited by free people of colour, with a rood or two of bared ground about it; or where the wood-cutter has erected himself a dwelling, and cleared i few acres for pasturage. Sometimes you see level ground on each side of you, for two or three hours at a stretch; at other times, a gently sloping hill 
presents itself; and often, on turning a point, the eye is plensed with the contrast of an almost perpendicular Firet height jutting into the water. The trees put you in mind of an eternal spring, with summer and antumn kindly blended into it.

Here you may sec a sloping extent of noble trees, whose folinge displays a charming varicty of every shade, from the lightest, to the darkest green and purple. The tops of some are crowned with bloom of the loveliest hue; while the boughs of others bend with a profusion of sceds and fruits.

Those whose heads have been bared by time, or blasted by the thunder-storm, strike the cye, as a mournful sound does the ear in music; and seem to beckon to the sentimentul traveller to stop a moment or two, and see that the forests which surround him, like men and kingdoms, lave their periods of misfortune and decay.

The first rocks of any considerable size, that are ob- Rocks. served on the side of the river, are at a place called Saba, from the Indian word, which means a stone. They appear sloping down to the water's edge, not shelvy, but smocth, and their exuberances rounded off, and, in some places, deeply furrowed, as though they had been worn with continual floods of water.

There are patches of soil up and down, and the huge stones amongst them produce a pleusing and novel effect. 
Finst You see a few coffee-trees of a fine luxuriant growth;
Jocnsey. and nearly on the top of Saba, stands the house of the postholder.

Nesidenec of the postholder.

He is appointed by government to give in his report to the protector of the Indians, of what is going on anongst them; and to prevent suspicious people from passing up the river.

When the Indians assemble here, the stranger may have an opportunity of seeing the Aborigines, dancing to the sound of their country music, and painted in their native style. They will shoot their arrows for him with an unerring aim, and send the poisoned dart, from the blow-pipe, true to its destination : and here he may often view all the different shades, from the red savage to the white man; and from the white man to the sootiest son of Africa.

Beyond this post, there are no more habitations of white men, or fiec people of colour.

Trees. In a comtry, so cxtensively covered with wood as this is, having every advantage that a tropical sun, and the richest mould, in many places, can give to vegetation, it is natural to look for trees of very large dimensions. But it is mre to meet with them above six yaris in circumference. If larger have ever existed, they have fallen a sacrifice, either to the axe or to fire.

If, however, they disuppoint you in size, they make ample muends in height. Heedless, and bankrupt, in all 
curiosity must he be, who can journey on without stopping Finst
Jotrney. to take a view of the towering mora. Its topmost branch, when naked with age, or dried by accident, is the favourite resort of the toncan. Many a time has this singular bird felt the shot finintly strike him, from the gun of the fowler beneatl, and owed his life to the distance betwixt them.

The trees which form these far-extending wilds, are as useful as they are omamental. It would take a volume of itself to describe them.

The green-heart, famous for its hardness and durability; the lackea, for its tonghness; the ducalabali, surpassing malnogany; the ebony and letter-wood, vieing with the choicest woods of the old world; the locusttree, yielding copal; and the hayawa and olon-trees, furnishing a sweet smelling resin, are all to be met with in the forest, betwixt the plantations and the rock Saba.

Beyond this rock, the country has been little explored; but it is very probable that these, and a vast collection of other kinds, and possibly many new species, are scattered up and down, in all directions, through the swamps, and hills, and savamnas of ci-devant Dutch Guiami.

On viewing the stately trees around him, the naturalist will observe many of them bearing leaves, and blossoms, and fruit, not their own.

The wild fig-trce, as large as a common English apple- The wild tree, often rears itself from one of the thick branches at fig-tree. the top of the mora; and when its fruit is ripe, to it the 
$\underset{\text { Jovkesy. birds resort for nourishment. It was to an indigested }}{\text { Fras }}$ seed, pussing through the body of the bird which had perehed on the inorn, that the fig-tree first owed its elevated stntion there. The sap of the mora raised it into full bearing ; but now, in its turn, it is doomed to contribute n portion of its own sap and juices towards the growtl of different species of vines, the seeds of which, also, the birds deposited on its branches. These soon vegetatc, and leenr finit in great quantities; so what with their usurpution of the resources of the fig-tree, and the fig-tree of the morn, the mora, unable to support a churge which unture never intended it should, languishes and dies under its burden; and then the fig-tree, and its usurping progeny of vines, receiving no more succour from their lnte fonter parent, droop and perish in their tum.

The bushrope.

A vine called the busli-rope by the wood-cutters, on aecount of its use in lunuling out the heaviest timber, has a singular appenrance in the forests of Demerara. Sometimes you see it nenrly as thick as a man's body, twisted like a corkscrew round the tnllest trees, and rearing its hend high ubove their topss. At other times, three or four of then, like strands in a eable, join tree and tree, and branch and branch together. Others, descending from on high, take root us soon as their extremity touches the ground, and nppenr like shrouds and stays supporting the maimmust of $n$ linc of battle ship; while others, 
sending out paral! oblique, horizontal, and perpendicular shoots in all clire tions, put you in mind of what travellers First
Journey. call a matted forest. Oftentimes a tree, above a hundred feet high, uprooted by the whirlwind, is stopped in its fall by these amazing cables of nature; and hence it is that you account for the phenomenon of seeing trees, not only vegetating, but sending forth vigorous shoots, though far from their perpendicular, and their trunks inclined to every degree from the meridian to the horizon.

Their heads remain firmly supported by the bush-rope; many of their roots soon refix themselves in the earth, and fiequently a strong shoot will sprout out perpendieularly from near the root of the reclined trunk, and in time become a fine tree. No grass grows under the trees; and few weeds, except in the swamps.

The high grounds are pretty clear of underwood, and with a cutlass to sever the small bush-ropes, it is not clifficult walking among the trees.

The soil, chiefly formed by the fallen leaves and de- soils. cayed trees, is very rich and fertile in the vallies. On the hills, it is little better than sand. The rains seem to have carried away, and swept into the vallies, every particle which nature intended to have formed a mould.

Four-footed animals are searce, considering how very Four-footed thinly these forests are inhabited by men.

Several species of the animal, commonly called tiger, though in reality it approaches nearer to the leopard, are 
Finst found here; and two of their diminutives, named tiger Jounsey. cats. The tapir, the lobba, and deer, afford excellent food, and chiefly frequent the swamps and low ground, near the sides of the river and ereeks.

In stating that four-footed animals are scarce, the peccari must be excepted. Three or four hundred of them herd together, and traverse the wilds in all clirections in quest of roots and fallen seeds. The Indians mostly shoot them with poisoned arrows. When wounded, they run about one hundred and fifty paces; they then drop, and make wholesome food.

The red monkey, erroneously called the baboon, is heard oftener than it is seen; while the common brown monkey, the bisa, and sacawinki rove from tree to tree, and amuse the stranger as he journies on.

A species of the polecat, and another of the fox, are destructive to the Indian's poultry; while the opossum, the guana, and salempenta, afford him a delicious morsel.

The small ant-bear, and the large one, remarkable for his long, broad, bushy tail, are sometimes seen on the tops of the wood ants' nests; the armadillas bore in the sand hills, like rabbits in a warren ; and the porcupine is now and then discovered in the trees over your head.

The sloth. This ton, is the native eountry of the sloth. His looks, his gestures, and his cries, all conspire to entreat you to take pity on him. These are the only weapons of 
defence which nature hath given him. While other animals assemble in herds, or in pairs range through these boundless wilds, the sloth is solitary, and almost stationary; he cannot escape from you. It is said, his piteous moans make the tiger relent, and turn out of the way. Do not then level your gun at him, or pierce him with a poisoned arrow; - he has never hurt one living creature. A few leaves, and those of the commonest and coarsest kind, are all he asks for his support. On comparing him with other animals, you would say that you could perceive deficiency, deformity, and superabundance in his composition. He has no cutting teeth, and though four stomachs, he still wants the long intestines of ruminating animals. He has only one inferior aperture, as in birds. He has no soles to his feet, nor has he the power of moving his toes separately. His hair is flat, and puts you in mind of grass withered by the wintry blast. His legs arc too short; they appear deformed by the manner in which they are joined to the body, and when he is on the ground, they secm as if only calculated to be of use in climbing trees. He has forty-six ribs, while the elephant has only forty; and his claws are disproportionably long. Were you to mark down upon a graduated scale, the different claims to superiority amongst the fourfooted animals, this poor, ill-formed creature's claim would be the last upon the lowest degree.

Demerara yields to no country in the world in her Birls. 
Fres wonderful and beautiful productions of the feathered JouRnex. race. Here the finest precious stones are fur surpassed by the vivid tints which adorn the birds. The naturalist may exclaim, that nature has not known where to stop in forming new species, and painting her requisite shades. Almost every one of those singular and elegant birds described by Buffon as belonging to Cayenne, are to be met with in Demerara; but it is only by an indefatigable naturalist that they are to be found.

The scarlet curlew breeds in innumerable quantities in the muddy islands on the const of Pomauron; the egrets and erabiers in the same place. They resort to the mudflats at ebbing water, while thousands of sandpipers and plovers, with here and there a spoonbill and flumingo, are scen amongst them. The pelieans go farther out to sea, but return at sundown to the courada trees. The humming-birds are chiefly to be found near the flowers at which each of the species of the genus is wont to feed. The pie, the gallinaceous, the columbine, and passerine tribes resort to the fruit-bearing trees.

The vulture. You never fail to see the common vulture where there is carrion. In passing up the river there was an opportunity of sceing a pair of the king of the vultures; they were sitting on the naked branch of a tree, with about a dozen of the common ones with them. A tiger had killed a goat the day before; he had been driven away in the act of sucking the blood, and not finding it safe or 
red

sed

list

top

les.

irds

be

able

in

rets

ud-

and

go,

; to

The

rers

ed.

ine

ere

or-

hey

out

had

vay

or prudent to return, the goat remained in the same place where he had killed it; it had begun to putrefy, and the vultures had arrived that morning to claim the savoury morsel.

At the close of chy, the vampires leave the hollow the trees, whither they had fled at the morning's dawn, and scour along the river's banks in quest of prey. On waking from sleep, the astonished traveller finds his hammock all stained with blood. It is the vampire that hath sucked him. Not man alone, but every unprotected animal, is exposed to his depredations; and so gently does this nocturnal surgeon draw the blood, that instead of being roused, the patient is lulled into a still profounder sleep. There are two species of vampire in Demerara, and both suck living animals : one is rather larger than the common bat; the other measures above two feet from wing to wing extended.

Snakes are frequently met with in the roods betwixt Snikes. the sea-coast and the rock Saba, chiefly near the creeks, and on the banks of the river. They are large, beautiful, and formidable. The rattlesnake seems partial to a tract of ground known by the name of Canal No. 3 ; there the effects of his poison will be long remembered.

The Camoudi suake has been killed from thirty to forty feet long; though not venomous, his size renders him destructive to the passing animals. The Spaniards in the Oroonoque positively affirm that he grows to the c 2
Firgt

JOURNEY. vampire. 
Finst length of seventy or eighty feet, and that he will destroy JOURNBY. the strongest and largest bull. His name seems to confirm this; there he is called " matntoro," which literally means " bull-killer." Thus he may be ranked amongst the deadly snakes; for it comes nearly to the same thing in the end, whether the victim dies by poison from the fings, which corrupts his blood and makes it stink horribly, or whether his body be erushed to mummy, and swallowed by this hideons beast.

The whipsnake of a beautiful changing green, and the coral with alternate brond traverse baris of black und red, glide from bush to bush, and may be handled with sufety; they are harmless little creatures.

The Labarri snake is speckled, of a dirty brown colour, and ean searcely be distinguished from the gromed or stump on which he is coiled up; he grows to the length of about cight feet, and his bite often proves futal in a few minutes.

Unrivalled in his display of every lovely colour of the rainbow, and unmatehed in the effects of his deadly poison, the coumacouchi glides undaunted on, sole monarch of these forests; he is commonly known by the name of the bush-master. Both man and beast fly before him, and allow him to pursue an undisputed path. He sometimes grows to the length of fourteen feet.

A few sinall caimen, from two to twelve feet long, may be observed now and then in passing up and down the 
river; they just keep their heads above the water, and a stranger would not know them from a rotten stump.

Finst

JotrNey.

Lizards of the finest green, brown, and copper colour, Lizarls. from two inches to two feet and a half long, are ever and anon rustling among the fallen leaves, and crossing the path before you; whilst the chameleon is busily employed in chasing insects round the trunks of the neighbouring trees.

The fish are of many different sorts, and well-tasted, Fish. but not, generally speaking, very plentiful. It is probable that their numbers are considerably thinned by the otters, which are much larger than those of Europe. In going through the overflowed savanuas, which have all a communication with the river, you may often see a dozen or two of them sporting amongst the sedges beforc you.

This warm and humid climate seems particularly adapted Insects. to the producing of insects; it gives birth to myriads, benutiful past description in their variety of tints, astonishing in their form and size, and many of them noxious in their qualities.

He whose eye can distinguish the various beauties of uncultivated nature, and whose ear is not shut to the wild sounds in the woods, will be delighted in passing up the river Demerara. Every now and then, the maam or tinamou sends forth one long and plaintive whistle from the depth of the forest, and then stops; whilst the yelping 
Funs of the toucan, and the shrill voice of the bird called

Jounary. Pi-pi-yo, is heard during the interval. The Campanero never fails to attract the attention of the passenger; at a distance of nearly three miles, you may hear this snowwhite bird tolling every four or five minutes, like the distant convent bell. From six to nine in the morning, the forests resound with the mingled cries and strains of the feathered race; after this, they gridually die away. From eleven to three all nature is hushed as in a midnight silence, and scarce a note is heard, saving that of the campanero and the pi-pi-yo; it is then that, oppressed by the solnr heat, the birds retire to the thickest shade, and wnit for the refreshing cool of evening.

At sundown the vampires, bats, and goat-suckers dart from their lonely retreat, and skim along the trees on the river's bank. The different kinds of frogs almost stun the ear with their hourse and hollow sounding croaking, while the owls and goat-suckers lament and mourn all night long.

About two hours before daybreak, you will hear the red monkey moaning as though in deep distress; the houtou, a solitary bird, and only found in the thickest recesses of the forest, distinctly articulates, " houtou, houtou," in a low and plaintive tone, an hour before sunrise; the maam whistles about the same hour; the hannaquoi, pataca, and maroudi announce his near approach 
to the eastern horizon, and the parrots and paroquets confirm his arrival there.

The crickets chirp from sunset to sunrise, and often during the day, when the weather is cloudy. The beterouge is exceedingly numerous in these extensive wilds, and not only man, but beasts and birds, are tormented by it. Mosquitos are very rare after you pass the third island in the Demerara, and sand-flies but seldom appear.

Courteous reader, here thon hast the outlines of an amazing landscape given thee; thou wilt see that the principal parts of it are but faintly traced, some of them searcely visible at all, and that the shades are wholly wanting. If thy soul partakes of the ardent flame which the persevering Mungo Park's did, these outlines will be enough for thee; they will give thee some idea of what a noble country this is ; and if thou hast but courage to set about giving the world a finished picture of it, neither materials to work on, nor colours to paint it in its true shades, will be wanting to thee. It may appear a diffieult task at a distance; but look close at at, and it is nothing at all; provided thou hast but a quiet mind, little more is necessary, and the genius which presides over these wilds will kindly help thee through the rest. She will allow thee to slay the fawn, and to cut down the mountain-cabbage for thy support, and to select from every part of her domain whatever may be necessary for the work thou art about; but having killed a pair of doves in order 
Fuss to enable thee to give mankind a true and proper deJotnasy. seription of them, thou must not destroy a thircl through wantonness, or to show what a good morksman thou art; that would only blot the picture thou art finishing, not colour it.

Though retired from the haunts of men, and even without a friend with thee, thou wouldst not find it solitury. The crowing of the hamaguoi will sound in thine cars like the duybreak town clock; and the wren and the thrush will join with thee in thy matin hymn to thy Creator, to thank him for thy night's rest.

At noon the Genius will lead thee to the troely, one leaf of which will defend thee from both sun mil ruin. And if, in the cool of the evening, thou hast been tempted to stray too fur from thy place of abode, and art deprived of light to write down the information thou hast collected, The fire-fly, the fire-fly, which thou wilt see in uhnost every bush uround thee, will be thy candle. Hold it over thy pocketbook, in any position which thon knowest will not hurt it, and it will afford thee ample light. And when thou hast done with it, put it kindly back again on the next branch to thee. It will want no other reward for its services.

When in thy hammock, should the thought of thy little crosses and disappointments, in thy ups and downs through life, break in upon thee, and throw thee into a The owl. pensive mood, the owl will bear thee company. She will 
tell thee thint hard has been her fite too ; and at intervals, "Whip-poor-Will," and "W Willy come go," will take up the tale of sorrow. Ovid has told thee how the owl once bonsted the human form, and lost it for a very small offence ; and were the poet nlive now, he would inform thee, that "Whip-poor-Will," and “Willy come go," are the shades of those poor African and Indian slaves, who died worn out and brokenhented. They wail and ery, " Whip-poor-Will," " Willy come go," all night long; and often, when the moon shines, you see them sitting on the green turf, near the houses of those whose ancestors tore them from the bosom of their helpless fumilies, which all probably perished through grief and waut, after their support was gone.

About an hour above the rock of Saba, stands the Simon'shut. habitation of an Indian, called Simon, on the top of a hill. The side next the river is almost perpendicular, and you may ensily throw a stone over to the opposite bank. Here there was an opportunity of seeing man in his rudest state. The Indiuns who frequented this habitation, though living in the midst of woods, bore evident marks of attention to their persons. Their hair was neatly collected, and tied up in a knot; their bodies fancifully painted red, and the paint was scented with hayawa. This gave them a gny and animnted appearance. Some of them had on necklnces, composed of the tecth of wild boars slain in the chase; many wore rings, and 
First others had an ornament on the left arm, midway betwixt Jounser. the slioulder and the elbow. At the close of day, they regularly bathed in the river below ; and the next morning seemed busy in renewing the faded colours of their fuces.

One day there came into the hut a form which literally might be ealled the wild man of the woods. On entering, le laid down a ball of wax, which he had collected in the forest. His hammock was all ragged and torn; and his bow, though of good wood, was without any ormament or polish ; " crubuit domino, cultior esse suo.", His face was mengre, his looks forbidding, and his whole appearance neglected. His long black hair hung from his head in matted confusion; nor had his body, to all appearance, ever been painted. They gave him some cassava bread and boiled fish, which he ate voracionsly, and soon after left the hut. As he went ont, you could observe no traees in his countenanee or demeanour, which indicated that he was in the least mindful of having been benefited by the society he was just leaving.

The Indians said that he had neither wife, nor child, nor friend. They had often tried to persuade him to come and live amongst them; but all was of no avail. He went roving on, plundering the wild bees of their honey, and picking up the fallen unts and fruits of the forest. When he fell in with game, he procured fire from two sticks, and cooked it on the spot. When a hut hap- 
twixt

they

corn-

their

rally

ring,

d in

orn ;

any

no."

hole

from

0 all

some

usly,

ould

lour,

ll of

ig.

hild,

$n$ to

vail.

their

the

from

hap- pened to be in his way, he stepped in, and asked for something to ent, and then months elapsed ere they saw Jounney. him again. They did not know what had caused him to be thus unsettled; he had been so for years; nor did they believe that even old age itself, would change the habits of this poor, harmless, solitary wandercr.

From Simon's, the traveller may reach the large fall, with ease, in four days.

The first falls that he meets are merely rapids, scarce a stone appearing above the water in the rainy season; and those in the bed of the river, barely high cnough to arrest the water's course, and by causing a bubbling show that they are there.

With this small change of appearance in the stream, the stranger observes nothing new, till he comes within eight or ten miles of the great fall. Each side of the river presents an uninterrupted range of wood, just as it did below. All the productions found betwixt the plantations and the rock Saba, are to be met with here.

From Simon's to the great fall, there are five habitations of the Indians. Two of them close to the river's side; the other three a little way in the forest. These Indlian habihabitations consist of from four to eight huts, situated on about in acre of ground, which they have cleared from the surrounding woods. A few pappaw, cotton, and mountain cabbage-trees, are scattered round them.

At one of these habitations, a small quantity of the D 2 
Fısт wournli pois(un was procured. It was in a little gourd. Wourali The Indinn who hund it, saicl that he had killed a number poison. of wild hogk with it, mid two tapirs. Appearances seemed to confirm whint he naid ; for on one side it had been nearly taken out to the bottom, nt different times, which probably would not lunve be(') the cane, had the first or second trial fuiled.

Itsstrength. Its strongtli wis proved on a middle-sized dog. He was wounderl in the thigh, in order 'that there might be no possibility of tomching a vital part. In three or four minutex la lsegun to le nffected, smelt at every little thing on the gromud momul him, and looked wistfully at the wombled punt. Soun after this he staggered, laid himself down, musl mever rose more. He barked once, though not as if' in puin. His voice was low and weak; and in a second nttemp)t it quite fuiled lim. He now put his hend betwixt his lone: legrs, and raising it slowly ugain, he fell over on his sick. His eye immediately became fixed, and thongh his extremitices every now and then shot convulsively, he nev(I) showed the least desire to raise up his hend. His lenert fluttered nuch from the time he luid down, Iunl ut intervuls bent very strong; then stopped for 11 moment (or two ; and then beat again, and continued fnintly houting wovernl minutes, after every other part of his body necumed dend.

In a funitel" of "III hour ufter he had received the poison he was guite motionless. 
ourd.

A few miles before you reach the great fall, and which, Firss indeed $_{2}$ is the only one which can be called a fall, large $\frac{\text { Jounswr. }}{\text { The great }}$ balls of froth come floating past you. The river appears full. beautifully marked with streaks of foan, and on your nearer approach the stream is whitened all over.

At first, you behold the fall rushing down a bed of rocks, with a tremendous noise, clivided into two foamy streams, which, at their junction again, form a small island covered with wood. Above this island, for a short space, there appears but one stream, all white with froth, and fietting and boiling amongst the liuge rocks which obstruct its course.

Higher up it is scen dividing itself into a short channel or two, and trees grow on the rocks which caused its separation. The torrent, in many places, has eaten deep into the rocks, and split them into large fragments, by driving others against them. The trees on the rocks are in bloom and vigour, though their roots are half bared, and many of them bruised and broken by the rushing waters.

This is the general appearance of the fall from the level of the water below, to where the river is smooth and quiet above. It must be remembered, that this is during the periodical rains. Probably, in the dry season, it puts on a very different appearanee. There is no perpendicular fall of water of any consequence throughout it, but the dreadful roaring and rushing of the torrent, down a 
Finst long, rocky, and moderately sloping channel, has a fine JOURNEY. effect; and the stranger returns well pleased with what he has seen. No animal, nor craft of any kind, could stem this downward flood. In a few moments the first would be killed, the second dashed in pieces.

The Indians have a path along-side of it, through the forest, where prodigious crabwood trees grow. Up this path they drag their canoes, and launch them into the river above; and on their return, bring them down the same way.

Iubitation of : $:$ in Acoway chief.
About two hours below this fall, is the habitation of an Acoway chief called Sinkerman. At night you hear the roaring of the fall from it. It is pleasantly situated on the top of a sand-hill. At this place you have the finest view the river Demerara affords : three tiers of hills rise in slow gradation, one above the other, before you, and present a grand and magnificent scene, especially to him who has been accustomed to a level country.

Here, a little after midnight, on the first of May, was heard a most strange and unaccountable noise; it seemed as though several regiments were engaged, and musketry firing with great rapidity. The Indians, terrified beyond description, left their hammocks, and crowded all together, like sheep at the approach of the wolf. There were no soldiers within three or four hundred miles. Conjecture was of no avail, and ull conversation next morning on the subject was as useless and unsatisfactory as the dead silence which succeded to the noise. 
a fine what could first the this river way. of an the d on inest rise and him was uned etry ond gerere ure on ead
He who wishes to reach the Macoushi country had better send his canoe over land, from Sinkerman's to the Essequibo.

There is a pretty good path, and meeting a creek about three quarters of the way, it eases the labour; and twelve Indians will arrive with it in the Essequibo in four days.

The traveller need not attend his canoe; there is a shorter and a better way. Half an hour below Sinkerman's, he finds a little creek on the western bank of the Demerara. After proeeeding about a couple of hundred yards up it, he leares it, and pursues a west-nortl-west direction by land for the Essequibo. The path is good, though somewhat rugged wi? the roots of trees, and here and there obstructed by fallen ones ; it extends more over level ground than otherwise. There are a few steep ascents and descents in it, with a little brook running at the bottom of them; but they are easily passed over, and the fallen trees serve for a bridge.

You may reach the Essecpuibo with ease in a day and a half; and so matted and interwoven are the tops of the trees above you, that the sun is not felt once all the way, saving where the space which a newly fallen tree occupied lets in his rays upon you. The forest contains an abundance of wild hogs, lobbas, acouries, powisses, maams, maroudis, and waracabas, for your nourishment, and there are plenty of leaves to cover a shed, whenever you are inclined to sleep. 


\section{Firkt Jotrney. \\ The Essequibo.}

The soil has three fourths of sand in it, till you come within half an hour's walk of the Essequibo, where you find a red gravel and rocks. In this retired and solitary tract nature's garb, to all appearanec, las not been injured by fire, nor her productions broken in upon by the exterminating hand of man.

Here the finest green-heart grows, and wallaba, purpleheart, siloabali, sawari, buletre, tauronira, and mora, are met with in vast abundance, far and near, towering up in majestic gran.icur, - traight as pillars, sixty or seventy feet high, without a knot or branch.

Traveller, forget for a little while the idea thon hast of wandering farther on, and stop and look at this grand picture of vegetable nature; it is a reflection of the crowd thou hast lately been in, and though a silent monitor, it is not a less cloquent one on that account.-See that noble purple-heart before thee! Nature has been kind to it. Not a hole, not the least oozing from its trunk, to show that its best days are past. Vigorous in youthful bloom and beauty, it stands the omanent of these sequestered wilds, and tacitly rebukes those base ones of thine own species, who have been hardy enough to deny the existence of Him who ordered it to flourish here.

Behold that one next to it !-Hark! how the hammerings of the red-headed woodpecker resound through its distempered boughs! See what a quantity of holes he has made in it, and how its bark is stained with the drops 
coine

you

litary

been

n by

Iple-

, are

up in

feet

hast

rand

rowd

re, it

that

id to

, to

thful

hese

as of

leny

ner-

its

ise

rops which trickle down from them. The lightuing, too, has blasted one side of it. Nature looks pale and wan in its leaves, and her resources are nearly dried up in its extremities; its sap is tainted; a mortal sickness, slow as a consumption, and as sure in its consequences, has long since entered its frame, vitiating and destroying the wholesome juices there.

Stcp a few paces aside, and cast thine eye on that remnant of a mora behind it. Best part of its branches, once so high and ornamental, now lic on the ground in sad confusion, one upon the other, all shattered and fungus-grown, and a prey to millions of insects, which are busily employed in clestroying them. One branch of it still looks healthy! Will it recover? No, it cannot; nature has already rum her course, and that healthylooking branch is only as a fallacious good symptom in him who is just about to die of a mortification, when he feels no more pain, and fancies his distemper has left him ; it is as the momentary glean of a wintry sun's ray close to the western horizon. See! while we are speaking a gust of wind has brought the tree to the ground, and made room for its successor.

Come further on, and examine that apparently luxuriant tauronira on thy right hand. It boasts a verdure not its own; they are false ornaments it wears : the bush-rope and bird-vines lave clothed it from the root to its topmost branch. The succession of fruit which it hath 
Finst borne, like good eheer in the houses of the great, has Jocnney. invited the bircls to resort to it, and they have disseminated beautiful, thougl destructive, plunts on its branches, which, like the distempers viee brings into the human frame, rob it of all its health and vigour; they have shortened its days, and probably in another year they will finally kill it, long before nature intended that it shoukl die.

Ere thou leavest this interesting scene, look on the ground around thee, and see what every thing here below must come to.

Behold that newly fallen wallaba! The whirlwind has uprooted it in its prime, and it has brought down to the ground a dozen small ones in its fall. Its bark has already begun to drop off'! And that heart of mora elose by it is fast yielding, in spite of its firm, tough texture.

The tree which thou passed but a little ago, and which perhaps has laid over youder brook for years, can now harclly support itself, and in a few months more it will have fallen into the water.

Put thy foot on that large trunk thou seest to the left. It secms entire, amid the surrounding fragments. Mere outward appearance, delusive phantom of what it once was! Tread on it, and like the fuss-ball, it will break into dust.

Sad and silent mementos to the giddy traveller as he wanclers on! Prostrate reinnants of vegetable nature, how incontestably ye prove what we must all at last come 
to, and how plain your mouldering ruins show that the firmest texture avails us naught when Heaven wills that we should cease to be!-

\footnotetext{
"The eloud-eapt towers, the gorgeous palaces, The solemn temples, the great globe itself, Yea, all which it inhabit, shall dissolve, And, like the baseless fabric of a vision, Leave not at wreck behind."
}

Cast thine cye around thec, and see the thousands of nature's productions. Take a view of them from the opening seed on the surface, sending a downward shoot, to the loftiest and the largest trees, rising up and blooming in wild luxuriance; some side by side, others separate; some curved and knotty, others straight as lanees; all, in beautiful gradation, fulfilling the mandates they had received from heaven, and though condemned to die, still never failing to keep up their species till time shall be no more.

Reader, canst thou not be induced to dedieate a few months to the good of the public, and examine with thy scientific eye the productions which the vast and wellstored colony of Demerara presents to thee?

What an immense range of forest is there from the rock Saba to the great fall! and what an uninterrupted extent before thee from it to the banks of the Essequibo! No doubt, there is many a balsam and many a medicinal root yet to be discovered, and many a resin, gum, and oil 
Finst yet umnoticed. Thy work would be a pleasing one, and JOUNEY. - thou mightest make several useful observations in it.

Would it be thought impertinent in thee to hazard a conjecture, that with the resources the government of Demerara has, stones might be conveyed from the rock Sabn to Stabrock, to stem the equinoctial tides, which are for ever sweeping away the expensive woolen piles round the mounds of the fort? Or would the timbermerchant point at thee in passing by, and call thee a descendant of La Manchn's knight, because thou maintainest that the stones which form the rapids might be removed with little expense, and thus open the navigation to the wood-cutter from Stabrock to the great fall? Or wouldst thou be deemed enthusiastic or biassed, because thon givest it as thy opinion that the climate in these high lands is exceedingly wholesome, and the lands themselves (apable of nourishing and maintaining any number of settlers? In thy dissertation on the Indians, thou mightest hint, that possibly they could be induced to help the new settlers a little; and that finding their labours well requited, it would be the means of their keeping up a constant commumicntion with us, which probably might be the means of laying the first stone towards their christianity. They are a poor, laarmless, inoffensive set of people, and their wandering and ill-provided way of living secms more to ask for pity from us, than to fill our heads with thonghts that they would be hostile to us. 
What a noble ficld, kind render, for thy experimental First philosopliy und speculations, for thy learning, for thy JoURnRY.

Ird a perseverance, for thy kind-heartedness, for every thing that is great and good within thee!

The aceidental traveller who has journied on from Stabrock to the rock Saba, and from thence to the banks of the Essequibo, in pursuit of other things, as he told thee at the begiuning, with but an indifferent interpreter to talk to, no firiend to converse with, and totally unfit for that which he wishes thee to do, can merely mark the outlines of the path he has trodden, or tell thee the sounds he has heard, or faintly describe what he has seen in the environs of lis resting-places; but if this be enough to induce thee to undertake the journey, and give the world a deseription of it, he will be amply satisfied.

It will he two days and a half from the time of entering the path on the western bank of the Demerarn till all be ready, and the canoe fairly afloat on the Essequibo. The new rigging it, and putting every little thing to rights and in its proper place, cannot well be done in less than a day.

After being night and day in the forest impervious to the sum and moon's rays, the sudden transition to light has a fine heart-checring effect. Welcome as a lost friend, the solar beam makes the frame rejoice, and with it a thousand enlivening thoughts rush at onee on the soul, and disperse, as a vapour, every sad and sorrowful 
Finar iden, which the deep gloom hind helped to collect there.

JoURNEr. In comning out of the woods, you see the westem bank of the Essequibo before you, low and flut. Here the river is twothirds as brond as the Demerarn at Stabrock.

$\begin{aligned} & \text { Face of the } \\ & \text { country. }\end{aligned}$
To the northward there is a hill higher than any in the Demerara ; and in the south-south-west quarter a mountain. It is fur awny, and appears like a bluish cloud in the horizon. There is not the lenst opening on either side. Hills, vallies, and lowlands, are all linked together by n chain of forest. Ascend the highest momntain, climb the loftiest tree, as fur as the eye can extend, which ever way it directs itself, all is luxuriant aud umbroken forest.

In about nine or ten hours from this, you get to un Indian habitation of three huts, on the point of an island. It is suicl that a Dutch post once stood here. But there is not the smallest vestige of it remaining, and, except that the trees appear younger than those on the other islands, which slows that the place has been cleared some time or other, there is no murk left by which you can conjecture that ever this was a post.

Islands. The many islands which you meet with in the way, enliven and change the seene, by the avenues which they make, which look like the mouths of other rivers, and break that long-extended sameness, which is seen in the Demerara.

Fills and rapicls.

Proceeding onwards, you get to the falls and rapids. In the rainy season they are very tedions to pass, and 
often stop your course. In the dry season, by stepping from rock to rock, the Indinns soon manage to get a canoe over them. But when the river is swollen, as it was in Mny, 1812, it is then a diflicult task, and often a dangerous one too. At that time many of the islunds were overflowed, the rocks covered, and the lower branches of the trees in the water. Sometimes the Indians were obliged to take every thing out of the canoe, cut a passage through the brunches, which linng over into the river, und then drag up the conoe by main force.

At one place, the fills form an oblique line cuite across the river, impassuble to the ascending cumoe, and you are forced to have it dragged four or five hundred yards by land.

It will take you five duys, from the Indian habitation, on the point of the island, to where these falls and rapids terminate.

There are no huts in the way. You must bring your own Cassava bread along with you, hunt in the forest for your ment, and make the night's shelter for yourseli.

Here is a noble range of hills, all covered with the Irills. finest trees, rising majestically one above the other, on the western bank, and presenting as rich a scene as ever the eye woul wish to look on. Nothing in vegetable nature i i conceived onore charming, grand, and luxuriant.

How the heart rejoices in viewing this beautiful land- 
First seape! when the sky is serene, the air cool, and the sum Jocrsex just sunk behind the mountain's top.

The hayawa tree perfumes the woods around: pairs of searlet Aras are continually crossing the river. The maan sends forth its plaintive note, the wren chants its evening song. The caprimulgus wheels in busy flight around the canoe, while "Whip-poor-Will" sits on the broken stump near the water's elge, complaining as the shades of night set in.

Rochs. A little before you pass the last of these rapids, two immense rocks appear, nearly on the summit of one of the many hills which form this firr-extending range, where it begins to fall off gradually to the south.

They look like two ancient stately towers of some (iothic potentate, rearing their heads above the surrounding trees. What with their situation, and their shape together, they strike the beholder with an idea of antipuated grandeur, which he will never forget. He may trasel far and near and see nothing like them. On looking at them through a glass, the summit of the southern one appeared crowned with bushes. The one to the north was quite bare. The Indians have it from their ancestors, that they are the abode of an evil genius, and they pass in the river below, with a reverential awe.

River Apourit-

In about seven hours from these stupendous sons of poura. the hill, you leave the Essequibo, and enter the river Apoura-poura, which falls into it from the south. The 
Apoura-poura is nearly one third the size of the Demerara at Stabroek. For two days you see nothing but level ground, richly clothed in timber. You leave the SipaJovrNeY. airs The romi to the right hand, and on the third day come to a little hill. The Indians have cleared about an acre of ground on it, and erected a temporary shed. If it be not intended for provision ground alone, perhaps the next white man who travels through these remote wilds will find an Indian settlement here.

Two days after leaving this, you get to a rising ground on the western bank, where stands a single hut; and about half a mile in the forest there are a few more; some of them square, and some round, with spiral roots.

Here the fish called Pacou is very plentiful : it is perhaps the fattest and most delicious fish in Guiana. It does not take the hook, but the Indians decoy it to the surfice of the water by means of the seeds of the crabwood tree, and then shoot it with an arrow.

You are now within the borders of Macoushia, inha- Mincousli bited by a different tribe of people, called Macoushi Indians; uncommonly dexterous in the use of the blowpipe, and famous for their skill in preparing the deadly vegetable poison, commonly called Wourali.

It is from this country that those beautiful paroquets, named Kessi-kessi, are procured. Here the crystal mountains are found; and here the three different species of 
Finst the Arn are ncell in grent abundance. Here, too, grows

Journer. the tree from which the gum-elastic is got : it is large, and as till as lilly in the forest. The wood has much the appeumuce of sycamore. The gum is contained in the bark: "low that is cut through, it oozes out very freely : it in quitc whitc, and looks as rich as cream : it hardens nlmost immedintely as it issues from the tree; so that it is very c'iny to collect a ball, by forming the

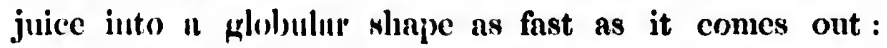
it becomes ncurly bluck by being exposed to the air, and is renl Indiun mubler without undergoing any other process.

The eleginit crented bird ealled Cock of the roek, admirubly described by Buflon, is a native of the woody ınountuius of Mucouslin. In the daytime, it retires amongst the diurkent rocks, and only comes out to feed a little before sumrine, nud nt sumset : he is of a gloony disposition, und, like the Houton, never associntes with the other birels of the forest.

The Indiuns, in the just mentioned settlement, seemed to alepend more on the wournli poison for killing their game, thaı щృon mıy thing else. They had only one gun, and it "ppeured lusty und neglected; but their poisoned Indian
blow-pipe. weapons were in finc order. Their blow-pipes lung from the roof of the liut, carcfully suspended by a silk grass cord; and on tuling " nearer view of them, no dust seemed to hinve collected there, nor had the spider spun 
the smallest web on them; which showed that they were in constant use. The quivers were close by them, with Jounnex. the jaw-bone of the fish Pirai tied by a string to their brim, and a small wicker-basket of wild cotton, whic'. hung down to the centre: they were nearly full of poisoned arrows. It was with difficulty these Indians could be persuaded to part with any of the wourali poison, though a good price was offered for it : they gave to understand that it was powder and shot to them, and very difficult to be procured.

On the sccond day after leaving this settlement, in passing along the Indians show you a place where once a white man lived. His retiring so far from those of his own colour and acquaintance secmed to carry something extraordinary along with it, and raised a desire to know what could have induced him to do so. It seems he had been unsuceessful, and that his creditors had treated him with as little merey as the strong generally show to the weak. Seeing his endeavours daily frustrated, and his best intentions of no avail, and fearing that when they had taken all he had, they would probably take his liberty too, he thought the world would not be hardhearted enough to condemm him for retiring from the evils which pressed so heavily on him, and which he had done all that an honest man could do, to ward off. He left his creditors to talk of him as they thought fit, and, bidding adicu for ever to the place in which he had once r 2 
Frrst seen better times, he penetrated thus far into these Journey. remote and gloomy wilds, and ended his days here.

Accorling to the new map of South America, Lake Purima, or the White Sca, ought to be within three or four days' walk from this place. On asking the Indians whether there was such a place or not, and deseribing that the water was fresh and good to drink, an old Indian, who appeared to be about sixty, said that there was such a place, and that he had been there. This information would have been satisfuctory in some degree, had not the Indians carried the point a iittle too far. It is very large, said another Indian, and ships come to it. Now, these unfortumate ships were the very things which were not wanted: had he but kept then out, it might have done, but his introducing them was sadly against the lake. Thus you must either suppose that the old savage and his companion had a confused idea of the thing, and that probably the Lake Parima they talked of was the Amazons, not far from the city of Para, or that it was their intention to deceive you. You ought to be cantions in giving credit to their stories, otherwise you will be apt to be led astray.

Many a ridiculous thing concerning the interior of Guiana has been propagated and received as true, merely because six or seven Indians, questioned separately, have agreed in their narrative.

$\Lambda$ sk those who live high up in the Demerarn, and they 
will, every one of them, tell you that there is a nation of Indians with long tails; that they are very malicious, cruel, and ill-natured; and that the Portuguese have been obliged to stop them off in a certain river, to prevent their depredations. They have also dreadful stories concerning a horrible beast, called the Water-mamma, which, when it happens to take a spite against a canoe, rises out of the river, and in the most unrelenting manner possible carries both canoe and Indians down to the bottom with it, and there destroys them. Ludicrous extravagances! pleasing to those fond of the marvellous, and excellent matter for a distempered brain.

The misinformed and timid court of policy in Deme- Aneclote. rara, was made the dupe of a savage, who came down the Essequibo, and gave himself out as king of a mighty tribe. This naked wild man of the woods seemed to hold the said court in tolerable contempt, and demanded immense supplies, all which he got; and moreover, some time after, an invitation to come down the ensuing year fo: more, which he took care not to forget.

This noisy chieftain boasted so much of his dynasty and donain, that the government was induced to send up an expedition into his territories to see if he had spoken the truth, and nothing but the truth. It appeared, however, that his palace was nothing but a hut, the monarch a needy savage, the heir-apparent nothing to inherit but his father's club and bow and arrows, and his officers of 
Frass state wild and uncultivated as the forests through which Journer. they strayed.

There was nothing in the hut of this savage, saving the presents he had reeived from government, but what was barely sufficient to support existenee; nothing that indicated a power to collect a hostile force; nothing that showed the least progress towards civilisation. All was rude and barbarous in the extreme, expressive of the utmost poverty, and a scanty population.

You may travel six or seven days without seeing a hut, and when you reach a settlement, it seldom contains more than ten.

The further you advance into the interior, the more you are convinced that it is thinly inhabited.

The day after passing the place where the white man lived, you see a creek on the left hand, and shortly after the path to the open country. Here you drag the canoe up into the forest, and leave it there. Your baggage must now be carried by the Indians. The creek you passed in the river, intersects the path to the next settlement; a large mora has fallen across it, and makes an excellent bridge. After walking an hour and a half, you come to the edge of the forest, and a savanua unfolds itself to the view.

The finest park that England boasts, falls far short of this delightful scene. There are about two thousand acres of grass, with here and there a clump of trees, and 
a few bushes and single trees, scattered up and down by the hand of nature. The ground is neither hilly nor level, but diversified with moderate rises and falls, so Jounkey. gently running into one another, that the eye cannot distinguish where they begin, nor where they end; while the distant black rocks have the appearance of a herd at rest. Nearly in the middle there is an eminence, which falls off gradually on every side; and on this the Indians have erected their huts.

To the northward of them the forest forms a circle, as though it had been done by art; to the eastward it hangs in festoons; and to the south and west it rushes in abruptly, clisclosing a new scene behind it at every step as you advance along.

This beautiful park of nature is quite surrounded by lofty hills, all arrayed in superbest garb of trees ; some in the form of pyramids, others like sugar-loaves, towering one above the other, some rounded off, and others as though they had lost their apex. Here two hills rise up in spiral summits, and the wooded line of communication betwixt them sinks so gradually, that it forms a crescent; and there the ridges of others resemble the waves of an agitated sea. Beyond these appenr others, and others past them; and others still farther on, till they can scarcely be distinguished from the clouds.

There are no Sand-flies, nor Bete-rouge, nor Mosquitos in this pretty spot. The Fire-flies, during the night, vie 
$\underset{\text { Jovrer }}{\text { Fre numbers and brightness with the stars in the firma- }}$ JOURNEY. ment above; the air is pure, and the north-cast breeze blows n refreshing gale throughout the day. Here the white-crested Maroudi, which is never found in the Demerara, is pretty plentiful; and here grows the tree which produces the moran, sometimes called balsamcirivi.

Route. Your route lies south from this place; and at the extremity of the savamna, you enter the forest, and journey along a winding path at the foot of a hill. There is no habitation within this day's walk. 'The traveller, ns usual, must sleep in the forest; the path is not so good the following day. The hills, over which it lies, me rocky, steep, and rugged; and the spaces betwixt them swanpy, and mostly knee-deep in water. After eight hours' walk, you find two or three Indian huts, surrounded by the forest; and in little more than half an hour from these, you come to ten or twelve others, where you pass the night. They are prettily situated at the entrance into a savanna. The eastern and western hills are still covered with wood; but on looking to the south-west quarter, you perceive it begins to die away. In these forests you may find plenty of the trees which yield the sweet-smelling resin called Acaiari, and which, when pounded and burnt on charcoal, gives a delightful fragrance.

From hence you proceed, in a south-west direction, through a long swampy savanna. Some of the hills which 

huge stones on them; nt ${ }^{1}$ ers quite wooded; others with their summits crowned, and their base quite bare ; and others again with their summits bare, and their base in thickest wood.

Half of this day's march is in water, nearly up to the knees. There are four ereeks to pass : one of them has a fullen tree across it. You must make your own bridge across the other three. Probably, were the truth known, these apparently four creeks are only the meanders of one.

The Jabiru, the largest bird in Guiana, feeds in the The Jabiru. marshy savamna through which you have just passed. He is wary and shy, and will not allow you to get within gunshot of him.

You sleep this night in the forest, and reach an Indian settlement albout three o'clock the next evening, after walking one third of the way through wet and miry ground.

But bad as the walking is throngh it, it is easier than where you cross over the bare hills, where you have to tread on sharp stones, most of them lying edgewise.

The ground gone over these twc last days, seems condemned to perpetual solitude and silence. There was not one four-footed animal to be scen, nor even the marks of one. It would have been as silent as midnight, and all as still and ummoved as a monument, had not the Jabiru 
Finss in the marsh, and a few vultures sonring over the mounJounxey. tain's top, shown that it was not (puite deserted by animated nature. There were no insects, execpt one kind of fly, about one fourth the size of the common house fly. It bit cruelly, and was much more tormenting than the mosepuito on the sen-const.

Arrow-root. This secms to be the native country of the Arrow-root. Wherever you passed through a patch of wood in a low situation, there you found it groving luxuriantly.

The Indian place you are now at, is not the proper place to have come to, in order tu rench the Portuguese frontiers. You have advanced too much to the westward. But there was-no alternative. The ground betwixt you and another small settlement (which was the right place to have gone to) was overflowed ; and thus, instead of procecding southward, you werc obliged to wind along the foot of the western hills, quite out of your way.

But the grand landscape this place affords, makes you ample amends for the time you have spent in reaching it. It would require great deseriptive powers to give a proper idea of the situation these people have chosen for their dwelling.

The hill they are on is steep and high, and full of immense rocks. The huts are not all in one place, but dispersed wherever they have found a place level enough for a lodgement. Before you ascend the hill, you see at intervals an acre or two of wood, then 
an open space, with a few huts on it ; thell wood again, and then an open space; and so on; till the intervening FIR8T
JoUnNEY. of the western hills, higher and steeper still, and crowded with trees of the loveliest shades, closes the enchanting scene.

At the base of this hill stretches an immense plain, Immense which appears to the eye, on this clevated spot, as level as a bowling-green. The mountains on the other side are piled one upon the other in romantic forms, and gradually retire, till they are undiscernible from the clouds in which they are involved. To the south-south-west this far-extending plain is lost in the horizon. The trees on it, which look like islands on the ocean, add greatly to the beauty of the landscape; while the rivulet's course is marked out by the Eta trees which follow its meanders.

Not being able to pursue the direct course from hence to the next Indian habitation, on account of the floods of water which fall at this time of the year, you take a circuit westerly along the mountain's foot.

At last a large and deep creek stops your progress : it Creek. is wide and rapid, and its banks very steep. There is neither curial nor canoe, nor purple-heart tree in the neighbourhood to make a $>$ ood skin to carry you over, so that you are obliged to swim across; and by the time you have formed a kind of raft, composed of boughs of trees and coarse grass, to ferry over your baggage, the day will be too far spent to think of proceeding. You 
Finst must be very eautious before you venture to sivim neross JounNEY.

this ereck, for the alligators are numerous, and near twenty feet long. On the present occasion, the Indians took uncommon precautions, lest they should be devoured by this eruel and vorneious reptile. They cut long sticks, and examined closely the side of the ereek for half a mile above and below the place where it wis to be crossed; and as soon as the boldest had swam over, he did the same on the other side, and then all followed.

After passing the night on the opposite bank, which is well wooded, it is a brisk walk of nine hours before you reach four Inclian luts, on a rising ground, a few lnundred paees from a little brook, whose bauks are covered with Concourite and Fita trees.

This is the place you onght to have come to, two days ngo, had the water permitted you. In crossing the plain at the most advantageous place, you are above ankle-deep in water for three hours; the remainder of the way is dry, the ground gently rising. As the lower parts of this spacious plain put on somewhat the appeurunce of a lake, during the periodieal rains, it is not improbable but that this is the place which hath given rise to the supposed cxistence of the famed Lake Parima, or El Dorado; but this is mere eonjecture.

Deer. A few cleer are feecling on the coarse rough grass of this far-extending plain; they keep at a clistance fiom you, and are continually on the look out. 
The spur-winged plover, and a species of the curlew, Finst black, with a white bar across the wings, nenrly as large Jocnser. ngain as the searlet eurlew on the sea-const, frequently rise before you. Here, too, the Moscovy duck is nuinerous: and large flocks of two other kinds whecl round you as you pass on, but kecp out of gunshot. The milk-white Egrets, and Jubirus, are distinguished at a grent distance ; and in the Fta and Concourite trees, you may observe flocks of scarlet and blue Arns feeding on the sceds.

It is to these trees that the largest sort of Toucan TheTournu. resorts. He is remarkible by a large black spot on the point of his fine yellow bill. He is very scaree in Demerarn, and never seen except near the sen-const.

'The nuts' nests linve a singular appenrnnce on this Ants' nests. plain; they are in vast abundance on those parts of it fiee from watcr, and are formed of an excecling laned yellow clay. They rise eight or ten fect from the ground, in a spiral form, impenetrable to the rain, and streng enough to defy the severest tomado.

The wourali poison, procured in these last-mentioned huts, secmed very good, and proved nfterwards to be very strong.

There are now no more Indian settlements betwixt you portugucse and the Portuguese frontiers. If you wish to visit their fort, it would be advisable to send an Indian with a letter from henee, und wait his return. On the present occasion a very fortumate circumstnnce occurred. The Portuguese 
Firet JoURNEY.

commander, had sent some Indians and soldiers to build a canoe, not far from this settlement; they had just finished it, and those who did not stay with it, had stopped here on their return.

The soldier who commanded the rest, said, he durst not, upon any account, convey a stranger to the fort : but he added, as there were two eanoes, one of them might be despntched with a letter, and then we could proceed slowly on in the other.

About three hours fiom this settlement, there is a river called Pirarara; and here the soldiers had left their canoes while they were making the new onc. From the Pirarara you get into the river Maou, and then into the Tacatou; and just where the Tacatou falls into the Rio Braneo, there stands the Portuguese frontier fort, exdled Fort St. Joachim. From the time of cmbarking in the river Pirnrara, it takes you four days before you reach this fort.

There was nothing very remarkable in passing down these rivers. It is an open country, producing a coarse grass, and interspersed with clumps of trees. The banks have some wood on them, but it alpears stinted and crooked, like that on the bleak hills in kingland.

The Tapir frequently plunged into the river; he was by no means shy, and it was easy to get $n$ shot at him on land. The Kessi-kessi paroquets were in great abundance; and the fine scarlet Aras innumerable in the Coucourite trees at a distance from the river's bauk. In 
the Tacatou was seen the Troupiale. It was charming to hear the sweet and plaintive notes of this pretty songster of the wilds. The Portuguese call it the nightingale of Guiana.

Towards the close of the fourth evening, the camoe, Message which had been sent on with a letter, met us with the lourtuguese commander's answer. During its absence, the nights commaniler. had been cold and stormy, the rain had fallen in torrents, the days clondy, and there was no sun to dry the wet hammocks. Exposed thus, dlay and night, to the chilling blast and pelting shower, strength of constitution at last failed, and a severe fever came on. The commander's answer was very polite. He remarked, he regretted much to say, that he had received orders to allow no stranger to enter the fronticr, and this being the case, he hoped I would not consider him as uncivil : however, continued he, I have ordered the soldier to land you at a certain distance from the fort, where we can consult together.

We had now arrived at the place, and the canoe which brought the letter returned to the fort, to tell the commander I had fallen sick.

The sun had not risen above an hour the morning after, when the Portuguese officer came to the spot where we had landed the preceding evening. He was tall and spare, and appeared to be from fifty to fifty-five years old; and though thirty years of service under an equa- 
First torial sum hud burnt und slurivelled up his face, still there JotrNEY. was something in it so inexpressibly affable and kind, that it set you immedintely at your ease. He came elose up to the liummock, and taking hold of my wrist to feel the pulse, "I IIn sorry, sir," said he, " to see that the fever hins tuken such hold of you. You shall go directly with me," continued he, " to the fort ; and though we have no cloctor" there, I trust," added he, " we shall soon bring youi nbont ngnin. The orders I have received forbidding the ndmission of strangers, were never intended to be put in lin'ec uguinst a sick English gentleman."

As the crmoc win proceeding slowly down the river towards the fort, the commander asked, with mueh more interest thun 1 question in ordinary eonversation is asked, where wis I on the night of the first of May? On telling him that I was "t In Indiun settlement a little below the great full in the Demerim, nud that a strange and sudden noise lund ulurued all the Indiuns, he said the sume astonishing noine luml roused every man in Fort St. Jonehim, nut thur they remained under arms till morning. He olsserved, thut he lind been quite at a loss to form any iden whut could huve caused the noise; but now learning that the mume noise had been heard at the same time fur awny from the Rio Branco, it struck him there must have becu nu enrthquake somewhere or other.

Good nomrishment und rest, und the unwearied attention and kindness of the Portuguese commander, stopped 
the progress of the fever, and enabled me to walk about in six days.

Fort St. Joachim was built about five and forty years ago, under the apprehension, it is said, that the Spaniards were coming from the Rio Negro to settle there. It has been much neglected; the floods of water have carried away the gate, and destroyed the wall on each side of it; but the present commander is putting it into thorough repnir. When funished, it will mount six nine, and six twelve pounders.

In a straight line with the fort, and within a few yards of the river, stand the eommander's house, the barracks, the chapel, the father confessor's house, and two others, all :. 1:ile intervals from each other ; and these are the onl bitlings at Fort St. Joachim. The neighbouring extensive plains aftord good pasturage for a fine breed of cattle, and the Portuguese make enough of butter and cheese for their own consumption.

On asising the old officer if there were such a place as Lake Parima, or El Dorado, he replied, he looked "pon it as imaginary altogether. "I have been above forty years," added he, " in Portuguese Guiana, but have never yet met with any body who has seen the lake."

So much for Lake Parima, or El Dorado, or the White Sea. Its existence at best seems cloubtful ; some aflirm that there is such a place, and others deny it.

" Grammatici certant, et adhuc sub judice lis est." 
Finst JoURNeY. Wourali poison.

Having now reached the Portuguese inland fiontier, and collected a sufficient quantity of the wourali poison, nothing remains but to give a brief aceount of its composition, its effects, its uses, and its supposed antidotes.

It has been ulready remarked, that in the extensive wilds of Demerarn and Essequibo, far awny from any European settlement, there is $\mathbf{n}$ tribe of Indians who are known by the name of Macoushi.

Though the wourali poison is used by all the South American savages betwixt the Amazons and the Oroonoque, still this tribe makes it stronger than any of the rest. The Indians in the vicinity of the Rio Negro are aware of this, and come to the Macoushi country to purchase it.

It effects. Much has been said concerning this fatal and extraordinary poison. Some have allirmed that its effects are almost instant:uneous, provided the minutest particle of it mixes with the blood; and others again have maintuined that it is not strong enongh to kill an animal of the size and strength of a man. The first have erred by lending a too willing ear to the marvellous, and believing assertions without sufficient proof. The following short story points out the neessity of a cautious examination.

Aneclote. One day, on asking an Indian if he thought the poiscn would kill a man, he replied, that they always go to battle with it; that he was standing by, when an Indian was shot with a poisoned arrow, und that he expired 
almost immediately. Not wishing to dispute this apparently satisfactory information, the subject was dropped. However, about an hour after, having purposely asked JOURNEY. him in what part of the body the said Indian was wounded, he answered, without hesitation, that the arrow entered betwixt his shoulders, and passed quite through his heart. Was it the weapon, or the strength of the poison, that brought on immediate dissolution in this case? Of course, the weapon.

The second have been misled by disappointment, caused by neglect in kecping the poisoned arrows, or by not knowing how to use them, or by trying inferior poison. If the arrows are not kept dry, the poison loses its strength, and in wet or damp weather it turns mouldy, and becomes quite soft. In shooting an arrow in this state, upon examining the place where it has entered, it will be observed that, though the arrow has penetrated deep into the flesh, still by far the greatest part of the poison has shrunk back, and thus, instead of entering with the arrow, it has remained collected at the mouth of the wound. In this ease the arrow might as well have not been poisoned. Probably, it was to this that a gentleman, some time ago, owed his disappointment, when he tried the poison on a horse in the town of Stabrock, the capital of Demerara; the horse never betrayed the least symptom of being affected by it.

Wishful to obtain the best information concerning this u 2 
Finss poison, and as repeated inquiries, in lieu of dissipating Jocksex. the surrounding shade, did but tend more and more to darken the little light that existed; I determined to penetrate into the country where the poisonous ingredients grow, where this pernicious composition is prepared, and where it is constantly used. Sucess nttended the adventure; and the information acquired, made amends for one hundred and twenty days passed in the solitudes of Guiana, and afforded a baln to the wounds and bruises which every traveller must expect to receive, who wanders through a thorny and obstructed patl..

Thou must not, courteous reader, expedt a disscrtation on the manner in which the wourali poisin operates on the system ; a treatise has been already written on the subject, and after all, there is probably still reason to doubt. It is supposed to affect the nervons system, and thus destroy the vital functions; it is also said to be perfectly larmless, provided it does not touch the blood. However, this is certain, when a suflicient quantity of it enters the blood, death is the incvitable consequenee; but there is no alteration in the colour of the blood, and hoth the blood and flesh may be eaten with safety.

All that thou wilt find here is a concise, unadomed account of the wourali poison. It may be of service to thee some time or other, shouldst thou ever travel through the wilds where it is used. Neither attribute to cruclty, nor to a want of feeling for the sufferings of the 
inferior animals, the ensuing experiments. The largel Finst animals were destroyed in order to have proof positive of Jouksw. the strength of a poison which hath hitherto been doubted; and the sumaller ones were killed with the hope of substantiuting that, which has commonly been supposed to be an antidote.

It makes a pitying heart ache to see a pool creature in distress and pain ; and too often has the ec....ssionate traveller occasion to heave a sigh as he journies on. However, here, though the kind-liearted will be sorry to read of an unoffending animal doomed to death, in order to satisfy a doubt, still it will be a relief to know that the victim was not tortured. The wourali poison destroys life's action so gently, that the victim appears to be in no pain whatever; and probably, were the truth known, it feels none, saving the momentary smart at the time the arrow enters.

A day or two before the Macous: Tndian prepares his poison, he goes into the forest in qu's if the ingredients. A vine grows in these wilds, which is called wourali. It is from this that the poison takes its name, and it is the principal ingredient. When he has procured enough of this, he digs ul) a root of a very bitter taste, ties them together, and then iolis about for two kinds of bulbous plants, which contain a green and glutinous juice. He fills a little quake, which he carries on his back, with the stalks of these; and lastly, ranges up and down till he 
Finst finds two species of ants. One of them is very large and Jounser. black, and so venomous, that its sting produces a fever: it is most commonly to be met with on the ground. The other is a little red ant, which stings like a nettle, and generally has its nest under the leaf of a slirub. After obtaining these, he has no more need to range the forest.

A quantity of the strongest Inclian pepper is used; but this he has alrealy planted round his hut. The pounded fungs of the Labarri suake, and those of the Counacouchi, are likewise added. These he commonly has in store; for when he kills a suake, he generally extracts the fungs, and keeps them by him.

Preparntion
of the woulof the won-
rali poison.

Having thus found the necessury ingredients, he scrapes the wourali vine and bitter root into thin shavings, and puts them into a kind of colander made of leaves : this he holds over an earthen pot, and pours water on the shavings: the liquor which comes through has the appearance of coffec. When a suflicient quantity has been procured, the shavings are thrown aside. He then bruises the bulbous stalks, and squeezes a proportionate quantity of their juice through his hands into the pot. Lastly, the suakes' fangs, ants, and pepper are bruised, and thrown into it. It is then placed on a slow fire, and as it boils, more of the juice of the wourali is added, according as it may be found necessary, and the scum is taken off with a leaf: it remains on the fire till rectuced 
to a thick sirup of a decp brown colour. As soon as it has arrived at this state, a few arrows are poisoned with First
Journay. it, to try its strength. If it answer the expectntions, it is poured out into a enlabash, or little pot of Indian manufacture, which is carcfully covered with a couple of leaves, and over them a piece of decr's skin, tied round with a cord. They keep it in the most dry part of the hut; and from time to time suspend it over the fire, to comrteract the effects of dampness.

The act of preparing this poison is not considered as a common one; the savage may shape his bow, fasten the barb on the point of his arrow, and make his other implements of destruction, either lying in his hnmmock, or in the midst of his family; but, if he has to prepare the wourali poison, many precautions are supposed to be necessary.

The women and young girls are not allowed to be Yabahou, or present, lest the Yabahou, or evil spirit, should do them evil spirit. harm. The shed under which it has been boiled, is pronounced polluted, and abandoned cver after. He who makes the poison must eat nothing that moming, and must continue fasting as long as the operation lasts. The pot in which it is boiled, must be a new one, and must never have held any thing before, otherwise the poison would be deficient in strength : add to this, that the operator must take particular care not to expose himself to the vapour which arises from it while on the fire. 
Firar Though this and other precnutions are tuken, such as Joukser. fiecunently wushing the finee und hands, still the Indians think that it nffects the health; and the operntor either is, or what is more probuble, supposes himself to be, sick for some days after.

Thus it appenrs that the muking the wournli poison is considered as a gloony und mysterious operation; and it would seem that they imngine it afficets others as well as him who boils it ; for nn Indian ngreed one evening to make some for me, but the next morning he declined having any thing to do with it, alleging that his wife was with child!

Here it might be asked, are all the ingredients just mentioned necessary, in order to produce the wourali poison? Though our opinions und conjectures may militate against the absolute necessity of some of them, still it wonld be hardly finir to pronounce them added by the hand of superstition, till proof positive can be obtained.

We might argue on the subject, and by bringing forward instances of Indian superstition, draw our conclusion by inference, and still remain in doubt on this head. You know superstition to be the offspring of ignorance, and of course that it takes up its abode amongst the rudest tribes of uncivilized man. It even too often resides with man in his more enlightened state.

The Augustan age furnishes numerous examples. A 
bone snatched from the jaws of a fisting bitch, and a fenther from the wing of a night owl,_" ossa ab ore Finst
Jothier. raptn jejwnre canis, plumamque nocturnae strigis," -were necessary for Cimidin's incmitutions. And in aftertimes, parson Evans, the Welshman, was treated most ungenteelly by inn enraged spirit, solely because he had forgotten a fumigntion in his witcli-work.

If, then, enlightened man lets his better sense give way, and believes, or nllows himself to be persuaded, that certain substamees and actions, in reality of no avail, possess a virtue which renders them useful in produeing the wished for effecet; may not the wild, untunght, unenlightened savage of Guima, add an ingredient which, on acconut of the ham it does him, he fincies mny be useful to the perfection of his poison, though in fact it be of no use at all? If $a$ bone suatched from the jaws of a fasting bitch be thought necessary in incautution ; or if witeheraft luve recourse to the raiment of the owl, becnuse it resorts to the tombs and inausoleums of the dead, and wails and hovers about at the time that the rest of animated nature sleeps ; certainly the savage may imagine that the imts, whose sting enuses a fever, and the tecth of the Labarri and Counacouchi snakes, which convey death in a very short spnee of time, are essentially necessary in the composition of his poison; and being once impressed with this idea, he will add them every time he makes the poison, and transmit the absolute use of them to his posterity. 
Funs The question to be answered scems not to be, if it is Jоскек. natural for the Indians to mix these ingredients, but, if they are essential to make the poison.

So much for the prepming of this vegetnble essence; terrible importer of denth, into whatever animal it enters. Let us now sec how it is used; let us examine the weapons which bear it to its destinntion, and take a view of the poor victim, from the time he receives his wound, till drath comes to his relief.

When a native of Macoushia goes in quest of feathered game or other birds, he seldom carries his bow and arrows.

Description of the blowpipe.

It is the blow-pipe he then uses. This extrnordinary tube of clenth is, perhaps, one of the grentest natural curiosities of Guiann. It is not found in the country of the Mncoushi. Those Inclians tell you that it grow's to the south-west of them, in the wilds which extend betwixt them and the Rio Negro. The reel must grow to an amazing length, as the part the Inclians use is from ten to eleven feet long, and no tapering can be perceived in it, one end being as thick as the other. It is of a bright yellow colour, perfectly smooth both inside and out. It grows hollow; nor is there the leust appenrnuce of a kuot or joint throughout the whole extent. The natives call it Ournh. This, of itself, is too slender to nuswer the end of $n$ blowpipe; but there is a species of Palmn, larger and stronger, and common in Guiann, and this the Indians make use of as a case, in which they put the Ourah. It is brown, 
susceptible of a fine polish, and apwenes as if it had joints five or six inches from ench other. It is called Samourah, and the pulp inside is easily extracted, by stecping it for a few days in water.

Thus the Ourah and Samourah, one within the other, form the blow-pipe of Guinn. The end which is applied to the mouth is tied round with a smull silk grinss cord, to prevent its splitting; mad the other end, which is apt to strike agninst the ground, is secured by the seed of the Acuero fruit, eut horizontnlly through the micldle, with $u$ hole mude in the end, through which is put the extremity of the blow-pipe. It is finstened on with string on che outside, and the inside is filled up with wild bees'-wax.

The urrow is from nine to ten inches long. It is linde the arrow. out of the lenf of a species of palm-tree, culled Concon, rite, hard and brittle, and pointed as sliarp as a needle. About in inch of the pointed end is poisoned. The oflere end is burnt, to make it still liarder, and wild cotton is put romul it for nbout an incls und a half. It repuires considernble practice to put on this cotton well. It must just be large enough to fit the hollow of the tube, and taper' off to nothing clownwards. They tie it on with a thread of the silk grass, to prevent its slipping off the arow.

The Indians have shown ingenuity in making a quiver The quiver. to hold the arrows. It will contuin from five to six hundred. It is generally from twelve so fourteen inches long, and in shape rescmbles a dice-box used at backgammon. 
Finst The inside is prettily done in basket-work, with wood not Jotrsex. - unlike bamboo, and the outside has a coat of wax. The cover is all of one piece, formed out of the skin of the Tapir. Round the eentre there is fastened a loop, large enough to admit the arm and shoulder, from which it hangs when used. To the rim is tied a little bunch of silk grass, and half of the jaw-bone of the fish called Pirai, with which the Indian serapes the point of his arrow.

Bcfore he puts the arrows into the quiver, he links them together by two strings of cotton, one string at each end, and then folds them round a stick, which is nearly the length of the quiver. The end of the stick, which is uppermost, is guarded by two little pieces of wood crosswise, with a hoop round their extremities, which appears something like a wheel; and this saves the hand from being wounded when the quiver is reversed, in order to let the bunch of arrows drop out.

There is also attached to the quiver a little kind of basket, to hold the wild cotton which is put on the blunt end of the arrow. With a quiver of poisoned arrows slung over his shoulder, and with his blow-pipe in his hand, in the same position as a soldier carrics his musket, see the Macoushi Indian advancing towards the forest in quest of Powises, Maroudis, Warncabas, and other feathered game.

The Indiam in pursuit of These generally sit high up in the tall and tufted trees, lis gaume. but still are not out of the Indian's reach; for his blow- 
pipe, at its greatest elevation, will send an arrow three hundred feet. Silent as midnight he steals under them, Finst and so cautiously does he tread the ground, that the fullen leaves rustle not benenth his feet. His cars are open to the least sound, while his eye, keen as that of the lynx, is employed in finding out the game in the thickest shade. Often le imitates their ery, and decoys them from tree to tree, till they are within range of his tube. Then taking a poisoned arrow from his quiver, he puts it in the blow-pipe, and collects his breath for the fatal putf.

About two fect from the end through which he blows, there are fastened two teeth of the Acomi, and these serve him for a sight. Silent and swift the arrow flies, and seldom fails to pieree the object at which it is sent. Sometimes the wounded bird remans in the same tree where it was shot, and in three mimites falls down at the Indian's feet. Should he take wing, his thight is of short duration, and the Indian, following the direction he has gone, is sure to find him dead.

It is natural to imagine that, when a slight wound only Efrects of is inflicted, the game will make its eseape. Far other- on the wise; the wourali poison almost instantancously mixes birl. with blood or water, so that if you wet your finger, and dash it along the poisoned arrow in the quickest mamer possible, you are sure to earry off some of the poison.

Though three minutes generally elapse before the 
First Joukney

convulsions come on in the wounded bird, still a stupor evidently tulke's pluce sooner, and this stupor manifests itself by an прpureut unwillingness in the bird to move. This whe rery visible in a dying fowl.

Having procured a healthy full-grown one, a short piece of a poisconcd blow-pipe arrow was broken off, and run up into its thight, us near as possible, betwixt the skin and the fleshe, in order that it might not be incommoded by the wound. For the first minute it walked about, but walked very slowly. unil did not appear the least agitated. During the serend minute it stood still, and began to peck the yrominl: and ere half another had clapsed, it frequently openced und shut its mouth. The tail had now dropped, and the wings almost tonched the ground. By the terminution of the third minute, it had sat down, searce uble to support its heal, which nodded, and then recovered itself, sunt then nodded again, lower and lower every time, like thut of a weary traveller slumbering in an erect position: lla eyes alternutely open and shut. The fourth minute bromght on convulsions, and life and the tifth terminuted tongethere.

The flesh of the gume is not in the least injured by the poison, nor doces it nppenr to corrupt sooner than that killed by the gun or knife. The body of this fowl was kept for sixte(nu hours, in a clinnte damp, and rainy, and within seven dengeres of the equator; at the end of which time it lind contracted no bad smell whatever; and there 
were no symptoms of putrefaction, saving that, just round Finst the wound, the flesh appeared somewhat discoloured.

The Indian, on his return home, carefully suspends his blow-pipe from the top of his spiral roof; seldom placing it in an oblique position, lest it should reeive a cast.

Here let the blow-pipe remain suspended, while you take a view of the arms which are made to slay the larger beasts of the forest.

When the Indian intends to chase the Peecari, or surprise the deer, or rouse the Tapir from his marshy retreat, he carries his bow and arrows, which are very different from the weapons already described.

The bow is grenerally from six to seven feet long, and The bow strung with a cord, spun out of the silk grass. The forests chase. of Guiana furnish many species of hard wood, tough and clastic, out of which beautiful and excellent bows are formed.

The arrows are from four to five fect in length, made arrows. of a yellow reed without a knot or joint. It is found in great plenty up and down throughout Guiana. A piece of hard wood, about nine inches long, is inserted into ihe end of the reed, and fistened with cotton well waxed. A square loole, an inch deep, is then made in the end of this piece of hard wood, done tight round with cotton to keep it from splitting. Into this square hole is fitted a spike of Concourite wood, poisoned, and which may be 
Firse kept there, or taken out at pleasure. A joint of bamboo, Jounsey. about as thick as your finger, is fitted on over the poisoned spike, to prevent accidents, and defend it from the rain, and is taken off when the arrow is about to be used. Lastly, two feathers are fastened on the other end of the reed to steady it in its lliglt?

Besides his bow and arrows, the Indian carries a little box made of bamboo, which holds a dozen or fifteen spihes. poisoned spilies, six inches long. They are poisoned in the following mamer: a small piece of wood is dipped in the poison, and with this they give the spike a first cont. It is then exposed to the sun or fire. After it is dry it receives another eoat, and then dried again:; after this a third coat, and sometimes a fourth.

'They take great eare to put the poison on thicker at the micldle than at the sides, by which means the spike retains the shrupe of a two-cedged sword. It is rathe: a tedious operation to make one of these arrows complete; and as the Indian is not funed for industry, except when pressed by hunger, he has hit upon a plan of preserving his arows which deserves notice.

About a quarter of an inch above the part where the Concourite spike is fixed into the scunare hole, he ents it half thronglı; and thus, when it has entered the animal, the weight of the arrow causes it to break off there, by which mens the arrow falls to the gromed uninjured; so that, should this be the only arrow he happens to have 
with him, and should another shot immediately occur, he has only to take another poisoned spike out of his little Einst bamboo box, fit it on his arrow, and send it to its Jochasy. destination.

Thus armed with deadly poison, and hungry as the hyena, he ranges through the forest in quest of the wild beasts' track. No hound can act a surer part. Without elothes to fetter him, or shoes to bind his feet, he observes the footsteps of the game, where an Duropean eye could not diseern the smallest vestige. He pursues it throngh all its turns and windings, with astonishing perseverance, and suecess generally crowns his efforts. The animal, after receiving the poisoned arrow, seldom retreats two hundred paces before it drops.

In passing over land from the Esseguibo to the Demerara, we foll in with a herd of wild hogs. Though eneumbered with bagggnge, and fattigued with a hard day's walk, an Indian got his bow ready, and let fly apoisoned arrow at one of them. It entered the cheek bone and kili a wilu broke off. The wild hog was found quite dend alsont hog. one hundred and seventy paces from the place where he had been shot. He affiorded us an excellent and wholesome supper.

Thus the savage of Guiana, independent of the common weapons of destruction, has it in his power to prepare a poison, by which he ean generally ensure to himself a supply of animal food; and the food so destroyed imbibes 
First IOUKNEY

no deleterions quaiities. Nature has been bountiful to him. She has not only ordered noisonous herbs and roots to grow in the unbounded forests through which he strays, but has also fiurnished an excellent reed for his arrows, and another still more singular for his blow-pipe : and planted trees of an umazing hard, tough, and clastic texture, out of which he forms his bows. And in order that nothing might be wanting, she has superadded a tree which yields him a fine wax, and disseminnted ip and down. a plant not unlike that of the pine-aprle, which affords him capital bow-strings.

Having now followed the Indian in the chase, and described the poison." int us take a nearer view of its aetiou, and observe a large animal expiring under the weight of its baneful virulenec.

Many have doubted the strength of the wourali poison. Should they ever by chance read what follows, probably their doubts on that score will be settled for ever.

Further remirtks on the sirulence of the poison.

In the former experiment on the dog, some faint resistance on the part of nature was observed, as if existence struggled for superiority; but in the following instance of the sloth, life sunk in death without the least apparent contention, without a cry, without a struggle, and without a groan. This was an $\mathbf{A i}$, or three-toed sloth. It was in the possession of a gentleman who was collecting curiosities. He wished to have it killed, in order to 
preserve the skin, and the wourali poison was resorted to as the easiest death.

Of all animals, not even the toad and tortoise exeepted, this poor ill-formed ereature is the most tenacious of life. It exists long after it has received wounds which would have destroyed any other muimal; and it may be said, on sceing a mortally wounded sloth, that life disputes with death every inch of flesh in its body.

The Ai was wounded in the leg, and put down on the floor, about two feet from the table; it contrived to reach the leg of the table, and fastened itself on it, as if wishful to aseend. But this was its last advancing step : life was ebbing fast, though impereeptibly; nor could this singular production of nature, which has been formed of a texture to resist death in a thousand shapes, malie any stand agniust the wourali poison.

First, one fore-leg let go its hold, and dropped down motionless by its side; the other gradually did the same. Zhe fore-legs having now lost their strength, the sloth slowly donbled its body, and placed its head betwixt its hind-legs, which still adhered to the table; but when the poison had affected these also, it sunk to the ground, but sunk so gently, that you conld not clistingnish the movement from an ordinary motion; and had you been ignorant that it was wounded with a poisoned arrow, you would never have suspeeted that it was dying. Its mouth was shut, nor had any froth or saliva collected there. 
Finst Jol'HEY.
There was no subsultus tendinum, or any visible alteration in its breathing. During the tentl minute from the time it was wounded it stirred, and that was all ; and the minute after, life's last spark went out. From the time the poison began to operate, you would have conjectured thint sleep was overpowering it, mil you would have exclaimed, "Pressitque jacentem, dulcis et alta quies, placidaeque simillima morti."

There are now two positive proofs of the effect of this fital poison; vi\%. the death of the dog, and that of the sloth. But still these animals were nothing remarkable for size; and the strength of the poison in large animals might yet be doubted, were it not for what follows.

Esperiment IIpon an ax.

A large well-fed ox, from nine hundred to a thousand pounds' weight, was tied to a stake by a rope sufficiently strong to allow him to move to and fro. Having no large Coucourite spikes at hand, it was judged necessary, on accomut of his superior size, to put three wild hog arrows into him ; onc was sent into each thigh just above the hock, in oreler to avoid wounding a vital part, and the third was shot traversely into the extremity of the nostril.

The poison seemed to take effect in four minutes. Conscious as though he would fall, the ox set himself firmly on his legs, and remained quite still in the same place, till about the fourteenth minute, when he smelled 
the ground, and appeared as if inclined to walk. He advaneed a pnee or two, staggered, and fell, and remained extendecl on his side, with his head on the ground. His eye, a few minutes ago so bright and lively, now became fixed and dim, and though you put your hand elose to it, as if to give him a blow there, he never closed his eyelid.

His legs were convulsed, and his head from time to time started involumtarily; but he never showed the least desire to raise it from the ground ; he breathed hard, and emitted foam from his mouth. The startings, or subsultus tendiunu, now became gradually weaker and weaker; his hinder parts were fixed in death; and in a minute or two more his head and fore-legs ceased to stir.

Nothing now remained to show that life was still within him, exeept that his heart faintly beat and fluttered at intervals. In five and twenty minutes from the time of his being wounded, he wias quite dead. His flesh was very sweet and savoury at dimner.

On taking a retrospective view of the two different ciencral otkinds of poisoned arrows, and the animals destroyed by them, it would appear that the cuintity of poison must be proportioned to the animal, and thus those probably labour under an error who imagine that the smallest particle of it introduced into the blood has almost instantancous effects.

Make an estimate of the difference in size betwixt the fowl and the ox, and then weigh a sufticient quantity of 


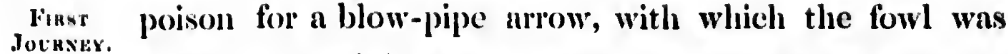
killed, and weigh also enough poison for three wild-hog arrows, which destroyed the ox, and it will appear that the fowl received much more poison in proportion than the ox. Hence the canse why the fowl died in five minntes, and the ox in five and twenty.

Indeed, were it the cuse, thint the smallest particle of it introduced into the blood has almost instmintaneous effects, the Indiun would not find it necessury to make the large arrow; that of the blow-pipe is much eavier made, and recpuires less poison.

Antidotes. And now for the anticlotes, or rather the supposed antidotes. The Indians tell you, that if the wounded animal be leck for a cousiderable time up to the mouth in water, the poison will not prove futal; also that the juice of the sugar-cane poured down the throat will comnteract the eflects of it. These antidotes were fairly tried upon full-grown healthy fowls, but they all died, as thongh no steps had been taken to preserve their lives. Rum was recommended and given to another, but with as little success.

It is supposed by some, that wind, introduced into the lumgs by means of a small pair of bellows, would revive the poisoned patient, provided the operation be continued for a suflicient length of time. It may be so; but this is a difficult and a tedious mode of cure, and he who is wounded in the forest, fir away from his friends, or in 
the hut of the savages, stunds but a poor chunce of Pinst being saved by it.

Had the Indians a sure antidote, it is likely they would carry it about with them, or resort to it imsuediately after being wounded, if at hand ; and their contidence in its efliency would greatly diminish the horror they betray when you point a poisoned arrow at them.

One day while we were eating a red monkey, erroneously called the babeou, in Demerarn, an Arowack Indian told an afficeting story of what linppened to a comrade of his. He was present at his cleath. As it did not interest this Indian in any point to tell a falsehood, it is very probable that his aceount was a true onc. If so, it appenrs that there is no certain antidote, or, at least, an autidote that could be resorted to in a case of urgent need ; for the Indian gave up all thoughts of life us soon as he was wounded.

The Arowack Indian said it was but four years ago Aneclote. that he and his companion were langing in the forest in quest of game. His companion took a poisoned arrow, and sent it at a red monkey in a tree above him. It was nearly a perpendicular shot. The arrow missed the monkey, and, in its descent, struck him in the arm, a little above the elbow. He was convineed it was all over with him. " I I shall never," said he to his companion, in a faltering voice, and looking at his bow as he said it, "I shall never," said he, " bend this bow agaiu." And 
Pons having said that, he took off his little bambon poison box, which hung neross his shoulder, und putting it together with his bow and arrows on the ground, he hid himself clown close by them, bid his compmion furewell, anul never spoke more.

He who is unfortumnte enough to be wounded by a poisoned arrow from Mncoushin, hat better not depend upon the common anticlotes for a cure. Many who linve been in Guiann, will recommend immerlinte immersion in water, or to take the juice of the sugne-enne, or to fill the mouth full of sult ; ased they recommend these antidotes, beenuse they linve got them from the Indians. But were you to nsk them if they erer saw these antidotes used with sucess, it is ten to one their mswer would be in the negative.

Wherefore let him reject these antidotes as umprofituble, and of no nvail. He hus got an netive and dendly foe within him, which, like Shakspenre's fell Sergeant Death, is strict in his arrest, and will allow himbut little time-very -very little time. In a few minutes he will be numbered with the dead. Life ought, if possible, to be preserved, be the expense ever so great. Should the part affected admit of it, let a ligature be tied tight round the wound, and have immedinte recourse to the knife :

\footnotetext{
"Continuo, culpam ferro compesee priusquam,
} Dira per infaustum serpant contagia corpus." 
And now, kind realer, it is time to bid thee furewell. The two ends proposed have been obtnined. The Portuguese inland frontice fort has been renelied, nud the Macoushi wournli poison acpuired. 'The account of this exeursion through the interior of (inima has been submitted to thy pertusnl, in order to indece thy ubler genius to unclertake a more extensive one. If my difficulties lanve arisen, or fevers come on, they have been eansed by the periodienl rains, which fill in torrents as the sun appronclies the tropic of Cancer. In dry wenther there would be no difliculties or sickiness.

Amongst the unany satisfinctory conclusions which thon wouldest be able to draw during the journey, there is one, which, perhaps, would plense thee not a hittle; and that is with regard to dogs. Mamy a time, no doubt, thou hast heard it hotly disputed, that dogs existed in Giniana previously to the arrival of the Spaniards in those parts. Whaterer the Spaniards introduced, and which bore no resemblance to my thing the Indiuns had been acenstomed to see, retnins its Spanish name to this day.

Thus, the Warow, the Arowack, the Acowny, the Miacoushi, and Carib tribes, call a hat, sombrero; it shirt, or any kind of cloth, canisa ; a shoe, zapato ; a letter, carta ; a fowl, gallina; gunpowder, colvora, (Spanish, polvora ;) ammunition, baln ; a cow, vaea ; and a dog, perro.

This argues strongly against the existence of dogs in 
First Guiana, before it was discovered by the Spanineds, and JO'RNEY. probably may be of use to thee, in thy next eanine disputc.

Politics. In a political point of view this country presents a large ficld for speculation. $\Lambda$ few years ago there was but little inducement for any Englishman to explore the interior of these rich and fine colonies, as the British government did not consider them worth holding at the peace of Amiens. Since that period their mother-country has been blotted out from the list of nations, and America has unfolded a new sleet of polities. On one side, the crown of Braganza, attacked by an ambitions chieftain, has fled from the palace of its ancestors, and now scems fixed on the banks of the Janeiro. Cayeme has yielded to its arms. La Plata has raised the standard of independence, and thinks itself sufliciently strong to obtain a govermment of its own. On the other side, the Caraceas are in open revolt, and shonld Santa Fé join them in good earuest, they may form a powerful association.

Thus, on cach side of ci-decant Dutch Guiana, most unexpected and astonishing changes have taken place. Will they raise or lower it in the scale of estimation at the court of St. James's? Will they be of benefit to these grmud and extensive colonies? Colonies enjoying perpetual summer. Colonies of the richest soil. Colonies eontaining within themselves every thing necessary for their support. Colonies, in fine, so varied in their 
quality and situation, as to be capable of bringing to perfection every tropical production; and only want the Finst support of govermment, and an enlightened governor, to render them as fine as the finest portions of the ecpuatorial regions. Kind reader, fare thee well.

Letter to the Portuguese Command'r.

MUY S]:X̄oR,

Como no tengo el honor, de ser conocido de VM. Io pienso mejor, $y$ mas decoroso, quedame aqui, hastayue huviere recibido su respuesta. Haviendo eaminado hasta la chosa, aclonde estoi, no quisicre volverme, antes de laver visto la fortaleza de los Portugueses; y pielo licencia de VM. para que me adelinte. Jlonmdissimus son mis motious, ni tengo proyecto ninguno, o de comercio, o de la soldadescis, no sicula yo, o comerciante, o olicial. Ilidalgo catolico soy, de hateienda in Vughatierra, y muchos años de mi vida he pasado en camitar. Cltimimente, de Demeraria vengo, la gual dexé el i dia de Abril, parat ver este hermoso pais, y coger unas enriosidades, especialmente, el reneme, que se llima Wourali. Lats mas recentes noticias que tonian en beucraria, antes de mi salieli, cran medias tristes, mediats alegres. Tristes digo, viento yue Valencia la eade en poder del enemigo comme y el Concral Blialie, y sus valientes tropas yuedan prisioneros de guerri. Alegres, al éontrario, porque Milord Wellington se hat apoderado de Ciudaul hodrigo. A pesar de la caida de Vialencia, parece claro al mundo, yue lats cosits del conemigo, estiun andaudo, de pejor a pejor cala dia. Nosotros debemos diar gracias al Altissimo, por harer sido servilo dextarnos ristigar ultimamente, a los robadores de sus sintas Yglesias. Se vern VM. que yo no escribo Portugues ni aun lo hablo, pero, haviendo aprendido el Castellano, no nos

I. 2 
Finst faltarí medio do communisur y tener conversacion. Ruego se escuse esta Jocins:

cartit escrita sin tinti, poreyue un Indio dexo eaer mi tintero y quebrose. Dios la dé „I V.I. Mullung años de saluul. Entretanto, tengo el honor de sore

Sil mas obedeciente servidor,

Carlos waterton. 


\section{R E M A R K S.}

"Incertus, quo fata ferant, ubi sistere detur."

KIND and gentle reader, if the journey in quest of the wourali poison has engaged thy attention, probalbly thon Finst mayest recollect that the traveller took leave of thee at Fort St. Joachim, on the Rio Branco. Shouldest thou $\begin{gathered}\text { Hllness at } \\ \text { furt St. }\end{gathered}$ wish to know what befell him afterwards, excuse the Joaclin. following uninteresting narrative.

Having had a return of ever, and awase that the farther he advanced into these wiid and lonely regions, the less would be the chance of reganiniing his health; he gove up all idea of proceeding onwards, and went

slowly back towards the Demerina, ncarly by the same Returns to ronte he had come.

On desecuding the falls in the Essecpuibo, which form Fills of the an oblique line cuite across the rive, it was resolved to Esscupuibo. push through them, the downward strean being in the 
Fuss canoc's favotir. At a little distance from the place, a large Jot RXEY.

tree had fallen into the river, and in the mean time the canoe was lashed to one of its branches.

The roaring of the water was dreadful ; it foamed and daslied over the rocks with a tremendous spraty, like breakers on a lee-shore, threatening destruction to whatever approached it. You would have thought, by the confusion it caused in the river, and the whirlpools it made, that Soylla and Charyhdis, and their whole progeny, had left the Mediterianean, and come and settled here. The channel was barely twelve feet wide, and the torrent in rushing down formed traverse furrows, which showed how near the rocks were to the surface.

Nothing could surpass the skill of the Indian who stecred the anoe. Ho looked stendfistly at it, then at the rockis, their cant an eye on the ehamel, and then looked at the canoc again. It was in vain to speak. The sound was lost in the roar of waters; but his eye showed that he had already passed it in inagination. He held up his pacldle in a position, as much as to say, that he would keep exactly amid chamel; and then made a sign to cut the bush-rope that held the eanoe to the fallen tree. The canoe drove down the torrent with inconceivable mapidity. It did not touch the rocks once all the way. The Indian proved to a nicety, " medio tutissimus ibis."

Shortly after this it rained ahmost day and night, the 
lightning flashing incessantly, and the roar of thunder Frnst awful beyond expression.

JoUnNey,

The fever returned, and pressed so heavy on him, that ind lightto all appearance his list day's march was over. How- never reever, it abated; his spirits rallied, and he marched again; turned. and after delays and inconveniences he reached the house of his worthy friend Mr. Edmionstone, in Mibiri creek, Reaches which falls into the Demerara. No words of his can keree. do justice to the hospitality of that gentleman, whose repeated encounters with the hostile negroes in the forest have been publicly rewarded, and will be remembered in the colony for years to come.

Here he learned that an eruption had taken place in St. Vincent's : and thus the noisc heard in the night of the first of May, which had caused such terror amongst the Indians, and made the garrison at Fort St. Joachim remain under arms the rest of the night, is accounted for.

After experiencing every linduess and attention from siils for Mr. Edmonstone, he sailed for Gramala, and from thence to St. Thomas's, a few days before poor Captain Peake last his life on his own quarter-deck, bravely fighting for his comtry on the coast of Guiama.

At St. Thomas's they show you a tower, a little distance st.Thomas's from the town, which they say formerly belonged to a Bucanier chicftain. Probably the fury of besiege;s has reduced it to its present dismantled state. What still 
Finst Jot'UNEY.

remains of it bears testimony of its former strength, and may brave the attack of time for centuries. Yon cammot view its mins, withont ealling to mind the exploits of those fierec and hardy hunters, long the terror of the western world. While you admire their mulaunted courage, you lament that it was often stained with cernelty; while you extol their scrupulous justice to each other, you will find " want of it towards the rest of mankind. Often possrised of enormous wealth, often in extreme porerty: 1): a trimmphant on the occan, and often forced to tly to tis iorests ; their life was an ever-changing scene of areance and retreat, of glory and disorder, of luxury atui hamine. Spain treated them as motlaws and pirates, while other European powers publicly disowned them. They, on the other hand, maintained, that injustice on the part of Spain first forced them to talie up arms in selfdefence; and that, whilst they kept inviolable the laws which they hat framed for their own common benefit and protection, they had a right to consider as foes, those who treated them as ontlaws. Under this impression they drew the sword, and rushed on as though in lawful war, and divided the spoils of victory in the scale of justice.

Leaves st. After leaving St. Thomess, a screre tertian agne, every Thomas's, and is at tincked by a tertian ague, and returns to Fingland. now aid then, kept putting the travelliz in mind, that his shattered frame, "starting and shivering in the inconstant blast, meagre and pale, the gliost of what it was," 
wanted repairs. Three years elapsed after arriving in England, before the agne took its final leave of him.

During that time, several experiments were made with the wourali poison. In London, an ass was inoculated with it, and died in twelve minutes. The poison was Experi1.0udon of the wourali inserted into the leg of another, round which a bandage had been previously tied a little above the place where the wourali was introduced. He walked about as usual, and ate his food as though all were right. After an hour hatd elapsed, the bandage wats untied, and ten minutes after death overtook him.

A she-ass received the wourali poison in the shoulder, and died apparently in ten minutes. An incision was then made in its windpipe, and through it the lungs were regularly inflated for two hours with a pair of bellows. Suspended animntion returned. The ass held up her head, and looked aromd; but the inflating being discontinued, she sunk once more in apparent death. The artificial breathing was immediately recommeneed, and continued without intermission for two hours more. This saved the ass from final dissolution; she rose up, and walked about; she seemed neither in agitation nor in pain. The wound, through which the poison entered, was healed without diflienlty. Her eonstitution, however, was so severely affected, that it was long a doulst if ever she would be well again. She looked lean and 
Finst sickly for above a year, but began to mend the spring Journky. after ; and by Midsummer became fat und frisky.

The kind-hearted render will rejoice on learning that Earl Perey, pitying her misfortumes, sent her down from London to Walton Hall, near Wakeficld. There she goes by the name of Wouralia. Wouralia shall be sheitered from the wintry storn; and when summer comes, slie shall feed in the finest pasture. No burclen shall be placed upon her, and she shall end her days in peace.

For three revolving autumus, the ague-beaten wanderer never saw, without a sigh, the swallow bend her flight towards warmer regions. He wished to go too, but could not ; for sickness had enfeebled him, and prudence pointed ont the folly of roving again, too soon, across the northern tropic. To be sure, the continent was now open, and change of nir might prove beneficial; but there was nothing very tempting in a trip across the chamel, and as for a tour through England :--England has long ceased to be the land for adventures. Indeed, when good King Arthur reappears to claim his erown, he will find things strangely altered here; and may we not look for his coming? for there is written upon his gravestone,

"Hic jacet Arturus, Rex quondam Rexque suturıs,"

"Here Arthur lies, who formeriy

Was king-and king again to be." 
Don Quixote was ulways of opinion that this famous king did not die, but that he was changed into a rnven by enchantment, and that the English are momentarily expecting his returu. Be this as it may, it is certain that when he reigned here, all was harmony and joy. The browsing herds passed from vale to vale, the swnius sang from the bluebell-teeming groves, and nymphs, with eglantine and roses in their neatly braided hair, went hand in hand to the flowery mead, to weave garlands for their lambkins. If by chance some rude uncivil fellow dared to molest them, or attempted to throw thorns in their path, there was sure to be a kinight errant, not far off, ready to rush forward in their defenec. But, alas! in these degenerate days it is not so. Should a hambess cottage maid wander ont of the highway to pluck a primrose or two in the neighbouring field, the hanghty owner stenly bids hel retire; and if a pitying swain hasten to escort her back, he is perhaps seized by the gaunt house-dog cre he rach her!

Aneas's route on the other side of Styx, could not have been much worse than this, though, by his account, when he got back to eartl, it appears that he had fallen in with "Bellua Lerne, horrendum stridens, flammisque, armata Chimara."

Moreover, he had a sibyl to guide his steps; and as such a conductress, now-a-days. could not be got for love or money, it was judged most prudent to refrain 
Fose from snuntering through this lind of freedom, and wait
Jounse. Jovaner. with patience the return of health. At last this longlooked for, ever-welcome stranger came. 


\section{SECOND JOURNEY.}

Is the year 1816, two dnys before 4 all cquinox, 1 sailed from Liverpool for Permambuco, in the southern hemisplhere, on the const of Brazil. There is little at suils for this time of the year, in the limropenn part of the Atlantic, to engage the attention of the naturulist. As you go down the ehannel, you see a few Divers and Gamnets. The middle-sized Gulls, with a black spot at the end of the wings, atterd you a little way into the Bay of Biseny. When it blow; a hard gale of wind, the stormy Petrel makes its nppearme. While the sea runs mountains high, and every wave threatens destruction to the labouring vessel, this little harbinger of storms is seen enjoying itsclf, on rapid pinion, up and down the roaring billows. When the storm is over, it appears no more. It is known to every English sailor, by the name of Mother Carey's chicken. It must have been hatched in 2 Eolus's eave, amongst a eluteh of squalls and tempests; for, whenever they get out upon the ocem, it always contrives to be of the party. 


$$
\rightarrow
$$




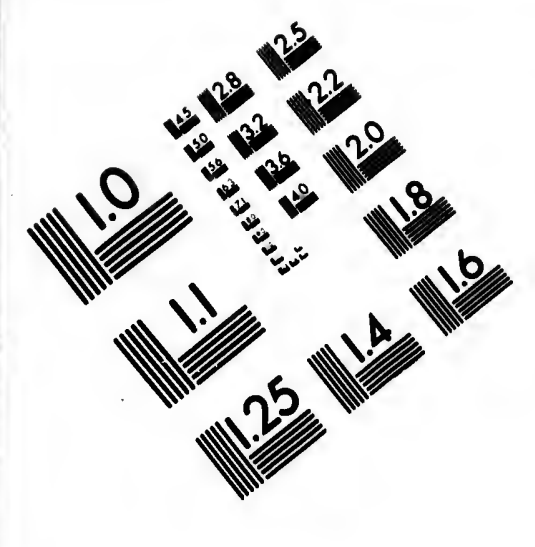

IMAGE EVALUATION
TEST TARGET (MT-3)

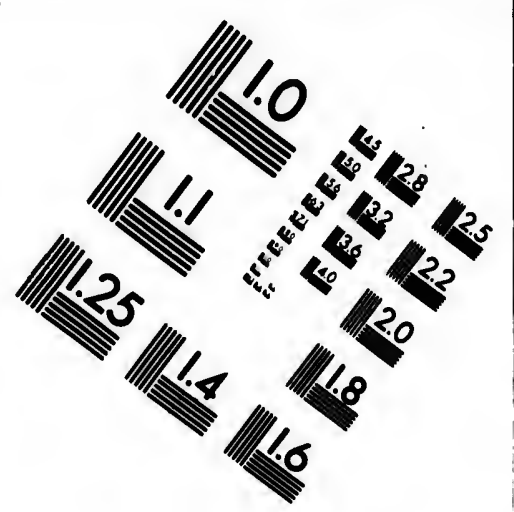

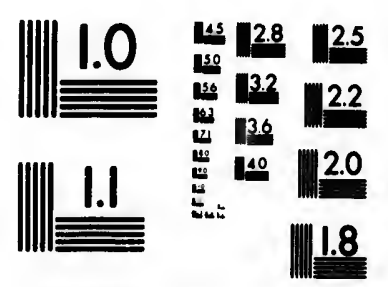

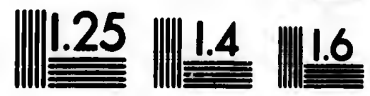

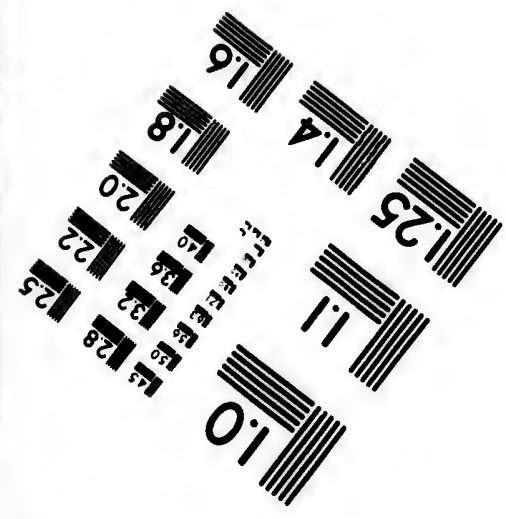

Photographic Sciences

23 WEST MAIN STRET Corporation

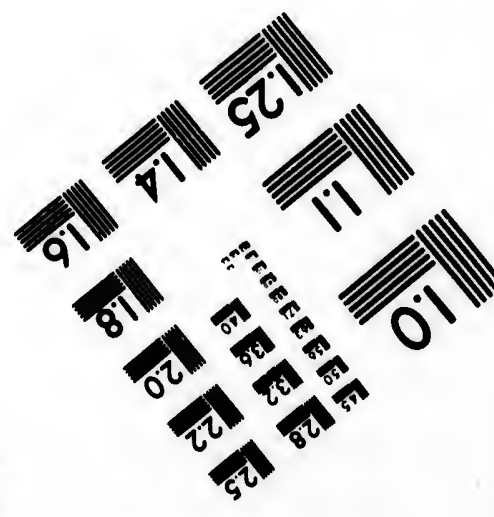

WESTER, N.Y. 14580
(716) 072-4503 

Secoso Though the calms, and storms, and adverse winds in Jourser. these latitudes, are vexatious, still, when you reach the Trade winds trade winds, you are amply repaid for all disappointments and inconveniences. The trade winds prevail about thirty degrees on each side of the equator. This part of the ocean may be called the Elysian Fields of Neptune's cmpire; and the torrid zone, notwitlistanding Ovid's remark, " non est habitabilis aestu," is rendered healthy and pleasant by these gently-blowing breezes. The ship glides smoothly on, and you soon find yourself within the northern tropic. When you are on it, Cancer is just over your head, and betwixt him and Capricorn is the high road of the Zodiac, forty-seven degrees wide, famous for Phaeton's misadventure. His father begged and entreated him not to take it into his head to drive parallel to the five zones, but to mind and keep on the turnpike which runs obliquely across the equator. " There you will distinetly see," said he, " the ruts of my chariot wheels, " manifesta rota vestigia cernes.", " But," added he, " even suppose you keep on it, and avoid the by-roads, nevertheless, my dear boy, believe me, you will be most sadly put to your shifts ; ' ardua prima via est,' the first part of the road is confoundedly stecp! ' ultima via prona est,' and after that, it is all down hill! Moreover, ' per insidias iter est, formasque ferarum,' the road is full of nooses and bulldogs, ' Hæmoniosque arcus,' and spring-guns, 'sævaque circuitu, curvantem brachia longo, Scorpio,' and steel-traps 
of uncominon size and shape." These were nothing in the eyes of Phaeton-go he would-so off he set-full speed, Secosd four in hand. He had a tough drive of it; and after doing a prodigious deal of mischief, very luckily for the world, he got thrown out of the box, and tumbled into the river Po.

Some of our modem bloods have been shallow enough to try to ape this poor empty-headed coachman, on a little scale, making London their Zodiac. Well for them, if tradesmen's bills, and other trivial perplexities, have not caused them to be thrown into the King's Bench.

The productions of the torrid zone are uneommonly Torrid zone. grand. Its plains, iss swamps, its savannas, and forests, abound with the largest serpents and wild beasts; and its trees are the habitation of the most beautiful of the feathered race. While the traveller in the old world is astonished at the elephant, the tiger, the lion, and rhinoceros, he who wanders through the torrid regions of the new, is lost in admiration at the Cotingas, the Toucans, the Humming-birds, and Aras.

The ocean, likewise, swarms with curiosities. Proba- Flying-fish. bly the Flying-fish may be considered as one of the most singular. This little scaled inhabitant of water and air, seems to have been more favoured than the rest of its finny brethren. It can rise out of the waves, and on wing visit the domain of the birds.

After flying two or three lundred yards, the intense 
heat of the sun has dried its pellucid wings, and it is obliged to wet them, in order to continue its flight. It just drops into the ocean for a moment, and then rises again and flies on ; and then descends to remoisten them, and then up again into the air; thus passing its life, sometimes wet, sometimes dry, sometimes in sumshine, and sometimes in the pale moon's nightly beam, as pleasure dictates, or as need requires. The additional assistance of wings is not thrown away upon it. It has full occupation both for fins and wings, as its life is in perpetual denger.

The Bonito and Albicore chase it day and night; but the Dolphin is its worst and swiftest foe. If it escape into the air, the Dolphin pushes on with proportional velocity beneath, and is ready to snap it up the moment it clescends to wet its wings.

You will often see above one hundred of these little marine aerial fugitives on the wing at once. They appear to use every exertion to prolong their flight, but vain are all their efforts ; for when the last drop of water on their wings is dried up, their flight is at an end, and they must drop into the ocean. Some are instantly devoured by their merciless pursuer, part $e$ le by swimming, and others get ont again as quick $a_{1_{1}}$ ussible, and trust once more to their wings.

It often happens that this unfortunate little creature, after alternate dips and flights, finding all its exertions of 
no avail, at last drops on board the vessel, verifying the old remark,

"Incidit in Scyllam, cupieus vitare Charybdim."

There, stumned by the fall, it beats the deck with its tail and dies. When eating it, you would take it for a fresh herring. The largest mensure from fourteen to fifteen inches in length. The dolphin, after pursuing it to the ship, sometimes forfeits his own life.

In clays of yore, the musician used to play in softest, sweetest strain, and then take an airing amongst the dolphins; “ inter delphinas Arion." But now-a-days, our tars have quite capsized the custom; and instead of riding ashore on the dolphin, they invite the dolphin aboard. While he is darting and playing around the vessel, a sailor goes out to the spritsailyard-arm, and with a long staff, leaded at one end, and armed at the other with five barbed spikes, he henves it at him. If successful in his aim, there is a fresh mess for all hands. The dying dolphin affords a superb and brilliant sight :-

" Mille trahit moriens, adverso sole colores."

All the colours of the rainbow pass and repass in rapid succession over his body, till the dark hand of deatl closes the scene.

From the Cape de Verd islands, to the coast of Brazil, you see several different kinds of gulls, which, probably, are bred in the island of St. Paul. Sometimes the large bird called the Frigate Pelican, soars majestically over 

Sacond the vessel, and the tropic bird comes near enough to let
Jounsy. you have a fair view of the long feathers in his tail. On the line, when it is calm, sharks of a tremendous size make their appearance. They are descried from the ship by means of the dorsal fin, which is above the water.

Frigate Pe- On entering the bay of Pernambuco, the Frigate Pelilican. can is seen watching the shoals of fish from a prodigious height. It scldom descends without a successful attack on its numerous prey below.

scenery. As you approach the shore the view is charming. The lills are clothed with wood, gradually rising towards the interior, none of them of any considerable height. A singular reef of rocks runs parallel to the coast, and forms the harbour of Pernambuco. The vessels are moored betwixt it and the town, safe from every storin. You enter the harbour through a very narrow passage, close by a fort built on the reef. The hill of Olinda, studded with honses and convents, is on your right hand, and an island thickly planted with cocon-nut trees, adds considerably to the scene on your left. There are two strong forts on the isthmus, betwixt Olinda and Pernambuco, and a pillar midway to aid the pilot.

Pernam- Pernambuco probably contains upwards of fifty thoubuco. sand souls. It stands on a flat, and is divided into three parts; a peninsula, an island, and the continent. Though within $\mathrm{n}$ few degrees of the line, its climate is remarkably salubrious, and rendered almost temperate by the refreshing sen breeze. Had art and judgment contributed their 
portion to its natural advantages, Pernambueo, at this day, would have been a stately ornament to the cosst of SECond Brazil. On viewing it, it will strike you that every one has built his house entirely for himself, and deprived public convenience of the little claim she had a right to put in. You would wish that this city, so famous for its harbour, so happy in its climate, and so well situated for commerce, could have risen under the flag of Dido, in lieu of that of Braganza.

As you walk down the streets, the appearance of the $\begin{gathered}\text { Streets and } \\ \text { houses. }\end{gathered}$ houses is not much in their favour. Some of them are very high, and some very low; some newly whitewashed, and others stained, and mouldy, and neglected; as though they had no owner.

The balconies, too, are of a dark and gloomy appearance. They are not, in generul, open, as in most tropical ciiies, but grated like a farner's dairy-window, though somewhat closer.

There is a lamentable want of cleanliness in the streets. The impurities from the houses, and the accumulation of litter from the beasts of burden, are unpleasant sights to the passing stranger. He laments the want of a police as he goes along; and when the wind begins to blow, his nose and eyes are too often exposed to a cloud of very unsavoury dust.

When you view the port of Pernambuco, full of ships Port of Perof all nations, when you know that the richest commonambuco. 
Secund JOURNEY.

dities of Europe, Africa, and Asia, are brought to it; when you see immense quantities of cotton, dye-wood, and the choicest fruits pouring into the town, you are apt to wonder at the little attention these people pay to the common comforts which one always expects to find in a large and opulent eity. However, if the inhabitants are satisfied, there is nothing more to be said. Should they ever be convineed that inconveniences exist, and that muisunces are too frecuent, the remedy is in their own hands. At present, certainly, they seem perfectly regardless of them ; and the Captuin-General of Pernambueo walks through the streets with as apparent content and composure, as an English statesman would proceed down Charing-cross. Custom reconciles every thing. In a week or two the stranger limself begins to feel less the things which annoyed him so much upon his first arrival, and after a few months' residence, he thinks no more about them, while he is partaking of the hospitality, and enjoying the elegance and splendour within doors in this great city.

Pilace of Close by the river side stands what is called the palace
the CaptainGeneral. of the Captain-General of Pernanbuco. Its form and appearance altogether, strike the traveller that it was never intended for the use it is at present put to.

Reader, throw a veil over thy recollection for a little while, and forget the cruel, uujust, and ummerited censures thou hast heard against an unoffending order. 
This palace was once the Jesuits' college, and originally built by those charitable fathers. Ask the aged and Srcosn respectable inhabitants of Pernambueo, and they will.tell thee that the destruetion of the Society of Jesus was $\begin{gathered}\text { Destruction } \\ \text { of the So- }\end{gathered}$ a terrible disaster to the public, and its consequences $\begin{gathered}\text { ciety of } \\ \text { Jesus. }\end{gathered}$ severely felt to the present day.

When Pombal took the reins of power into his own hands, virtue :nd leaning beamed bright within the college walls. Public catcehism to the children, and religious instruction to all, flowed daily from the mouths of its venerable priests.

They were loved, revered, and respeeted throughout the whole town. The illuminating philosophers of the day had sworn to exterminate christian knowledge, and the college of Pernambuco was doomed to founder in the general storm. To the long-lasting sorrow and disgrace of Portugal, the philosophers blinded her king, and flattered her prime minister. Pombal was exactly the tool these sappers of every public and private virtue wauted. He had the naked sworl of power in his own hand, and his heart was hard as flint. He struck a mortal blow, and the Society of Jes:s, throughout the Portuguese dominions, was no more.

One morning all the fathers of the eollege in Pernambuco, some of them very old and feeble, were suddenly ordered into the refeetory. They had notice beforehand of the futal storm, in pity from the govemor, but not 
Sacond one of them abandoned his charge. They had done their Jovanzr. duty, and had nothing to fear. They bowed with resignation to the will of henven. As soon as they had all reached the refectory, they were there locked up, and never more did they see their rooms, their friends, their scholars, or acquaintunce. In the dend of the following night, a strong guard of soldiers literally drove them through the strects to the water's edge. They were then conveyed in boats nboard a ship, nnd steered for Bahin. Those who survived the barbarous treatment they experienced from Pombal's creatures, were at last ordered to Lisbon. The college of Pernambuco was plundered, and some time after an elephant was kept there.

Thus the arbitrary hand of power, in one night, smote and swept away the sciences; to which succeeded the low vulgar bulloonery of a showman. Virgil and Cicern made wiy for a wild benst from Angola! and now a guard is on duty at the very gate where, in times long past, the poor were daily fed!!!

Trust not, kind reader, to the envious remarlis which their encmies have scattered fur and near; believe not the stories of those who have had a hand in the sad tragedy. Go to Brazil, and see with thine own eyes the effect of Pombal's short-sighted policy. There vice reigns triumphant, and learning is at its lowest ebb. Neither is this to be wondered at. Destroy the compass, and will the vessel find her far distant port? Will the flock keep 
together, and eseape the wolves, after the shepherds are all slain? The Brazilinns were told, thnt public eduention would go on just as usunl. They might have asked governinent, who so able to instruct our youth, as those whose knowledge is proverbial? who so fit, as those who enjoy our entire eonfidence? who so worthy, as those whose lives are irreproachable?

They soon found thut those who sueceded the fathers of the Society of Jesus, had neither their manner nor their abilities. They had not made the instruction of youth their particular study. Moreover, they entered on the field after a defent, where the officers had all been slain; where the plan of the campaign was lost; where all was in sorrow and dismay. No exertions of theirs could rally the dispersed, or skill prevent the fatal consequences. At the present day, the seminary of Olinda, in comparison with the former Jesuits' college, is only as the waning moon's beam to the sun's mericlim splendour.

When you visit the places where those learned fathers once flourished, and see with your own eyes the evils their dissolution has caused; when you hear the inlabitants telling you how good, how clever, how charitable they were; what will you think of our poet laureate, for calling them, in his " History of Brazil," " Missioners, whose zeal the most funatical was directed by the coolest policy?"

Was it funatical to renounce the honours and comforts of this transitory life, in order to gain eternal glory in 
sscosn the next, by denying themselves, nnd tuking up the eross? JoUnNEY.

Was it fanatical to prench snlvution to innumernble wild liordes of Americans? to clothe the muked? to encournge the repenting simner? to nid the lying Christinn? The fathers of the Society of Jesus did ull this. And for this their zenl is pronounced to be the most fumtical, directed by the coolest policy. It will puzzle many a clear brain to comprelnend how it is possible, in the muture of things, thint zeal the most funatical should be directed by the coolest policy. Ah, Mr. Laurente, Mr. Lamrente, that " quidlibet nudendi" of yours, may now and then gild the poet, at the same time that it makes the historim cut a sorry figure!

Could Finther Nobrega rise from the tomb, he would thus address you :-“ Ungrateful Englishman, you hnve drawn a great part of your information from the writings of the Society of Jesus, and in return you attempt to stain its character by telling your countrymen that ' we taught the idohtry we believed!' In spenking of me, you sny, it was my happy fortume to be stutioned in a country where none but the good principles of my order were called into nction. Ungenerous laurente, the narrow policy of the times has kept your countrymen in the dark with regard to the true clinrncter of the Society of Jesus; and you draw the bandage still tighter over their cyes, by a malicious insinuation. I lived, and taught, and died in Brazil, where you state that none but the 
good principles of my order were called into action, and still, in most ubsolute contrulietion to this, you remark we believed the illolul'y we tnught in Brazil. Thus we brought none but good principles into action, and still taught idolntry!

"Agnin, you stato there is 110 individual to whose talents Brnzil is no grently und permunently indebted as mine, and that I must loe regurded as the foumcler of that system so successfully pursued by the jesuits in Parnguay; a system productive of un mikch good as is compatible with pious finud. Thum you muke me, at one and the same time, $n$ tencher of none but good principles, and a teacher of idolutry, und n heliever in idolatry, and still the founder of a nywtem for which Brazil is greatly and permanently indebted to me, though, by the by, the system was only productive of as much good as is compatible with pious frnud!

"What memus ull this? After reading such incomparable nonsense, should your eountrymen wish to be properly informed concerning the Society of Jesus, there are in England documents enongh to show that the system of the jesnits whs $n$ nystem of cluristian charity towards their fellow-erentures, mlministered in a mamer which human prudenee juelged best ealeulated to ensure success; and that the idolntry which you uncharitably affirm they taught, was renlly and truly the very same faith which the Catholic cliurch taught for centuries in 
SEcosp England, which she still teaches to those who wish to JOUNEE. hear her, and which she will continue to teach, pure and unspotted, till time shall be no more."

Environs of Pernambuco.

The environs of Pernambuco are very pretty. You see country houses in all directions, and the appearance of here and there a sugar plantation enriches the scenery. Palm-trees, cocon-nut-trees, orange and lemon groves, and all the different fruits peculiar to Brazil, are here in the greatest abundance.

At Olinda there is a national botanical garden : it wants space, produce, and improvement. The forests, which are several leagues off, abound with birds, beasts, insects, and serpents. Besides a brilliant plumage, many of the birds have a very fine song. The Troupiale, noted for its rich colours, sings delightfully in the environs of Pernambuco. The red-headed Finch, larger than the Europeun sparrow, pours forth a sweet and varied strain, in company with two species of wrens, a little before daylight. There are also several species of the thrush, which have a song somewhat different from that of the European thrush ; and two species of the linnet, whose strain is so soft and sweet that it dooms them to captivity in the houses. A bird called here Sangre do Buey, blood of the ox, cannot fail to engage your attention : he is of the passerine tribe, and very common about the houses; the wings and tail are black, and every other part of the boty a flaming red. In Guiana, there is a 
species exactly the same as this in shape, note, and economy, but differing in colour, its whole body lueing like black velvet; on its breast a tinge of red appears through the black. Thus nature has ordered this little Tangara to put on mourning to the north of the line, and wear scarlet to the south of it.

For three months in the year the environs of Pernain- Seasons. buco are animated beyond description. From November to March the weather is particularly fine; then it is that rich and poor, young and old, foreigners and natives, all issue from the city to enjoy the country till Lent appronches, when back they hie them. Villages and hamlets, where nothing before but rags was scen, now shine in all the elegance of lress; every house, every room, every shed become eligible places for those whom nothing but extreme necessity could have forced to live there a few weeks ago : some join in the merry damee, cthers saunter up and down the orange-groves; and towards evening, the ronds become a moving scene of silk and jewels. The gaming-tables have constant visitors; there, thousands are daily and nightly lost and won; parties even sit down to try their luck round the outside of the door ns well as in the room :-

“ Vestibulum ante ipsum primisque in fancibus aule Luctus et ultrices, posuere sedilia curre.

About six or seven miles from Pernambuco stands a Monteiro. pretty little village called Monteiro; the river runs close o 2 
Secono by it, and its rural beauties seem to surpass all others in Journay. the neighbourhood; there the Captain-General of Pernambuco resides during this time of merriment and joy.

The traveller, who allots a portion of his time to peep at his fellow-creatures in their relaxations, and accustoms himself to read their several little histories in their looks and gestures as he goes musing on, may have full occupation for an hour or two every day at this season amid the variegated scenes around the pretty village of Monteiro. In the evening groups sitting at the door, he may sometimes see with a sigh how wealth and the prince's fivour cause a booby to pass for a Solon, and be reverenced as such, while perhaps a poor neglected Camoens stands silent at a clistance, awed by the clazzling glare of wealth and power. Retired from the public road he may see poor Maria sitting under a palın-tree, with her elbow in her lap, and her head leaning on one side within her hand, weeping over her forbidden bans. And as he moves on " with wandering step and slow," he may hear a brokenhearted nymph ask her fuithless swain,-

"How could you say my face was fair, And yet that face forsake ?

How could you win my virgin heart, Yet leave that heart to break ?"

One afternoon, in an imfrequented part not far from Monteiro, these adventures were near being brought to $\mathbf{a}^{\prime}$ 
si ly and a final close : six or seven blackbirds, with a . . nite spot betwixt the shoulders, were making a noise, and passing to and fro on the lower branches of a tree in an abandoned, weed-grown, orange orchard. In the long grass underneath the tree, apparently a pale green grasshopper was fluttering as though it had got entangled in it. When you once fancy that the thing you are looking at is really what you take it for, the more you look at it, the more you are convinced it is so. In the present case, this was a grasshopper beyond all doubt, and nothing more remained to be done but to wait in patience till it had settled, in order that you might run no risk of breaking its legs in attempting to lay hold of it while it was fluttering-it still kept fluttering; and having cuietly approached it, intending to make sure of it-behold, the head of a large rattlesnake appeared in the grass close by : an instantaneous spring backwards prevented fatal consequences. What had been taken for a grasshopper was, in fict, the elevated rattle of the snake in the act of announeing that he was quite prepared, though unwilling, to make a sure and deadly spring. He shortly after passed slowly from under the orange-tree to the neighbouring wood on the side of a lill : as he moved over a place bare of grass and weeds he appeared to be about eight feet long; it was he who had engaged the attention of the birds, and made them heedless of danger from another quarter : they 
Seconb

JoURneY.

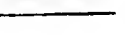

Rainy Seasons.

flew away on his retiring; one alone left his little life in the air, destined to become a specimen, mute and motionless, for the inspection of the curious in a far distant clime.

It was now the rainy season; the birds were moulting; fifty-eight specimens of the handsomest of them in the neighbourhood of Pernambuco had been collected; and it was time to proceed elsewhere. The conveyance to the iuterior was by horses; and this mode, together with the heavy rains, would expose preserved specimens to almost certain clamage. The journey to Maranhan by land, would take at least forty days. The route was not wild enough to engage the attention of an explorer, or civilized énough to afford common comforts to a traveller. By sen there were no opportunities, except slave ships. As the transporting poor negroes from port to port for sale pays well in Brazil, the ships' decks are crowded with them. This would not do.

Excuse here, bencvolent reader, a small tribute of gratitude to an Irish family, whose urbanity and goodness have long gained it the esteem and respect of all ranks in Pernambuco. The kindness and attention $I$ received from Dennis Kearney, Esq. and his amiable lady, will be remembered with gratitude to my dying day.

Embarks
forcayenne. After wishing farewell to this hospitable fmmily, I embarked on board a Portuguese brig, with poor accommodations, for Cayenne in Guiana. The most eligible bed- 
room was the top of a hen-coop on deck. Even here, second an unsavoury little beast, called bug, was neither shy Joursky. nor deficient in appetite.

The Portuguese seamen are famed for catching fish. One evening, under the line, four sharks made their appearance in the wake of the vessel. The sailors caught them all.

On the fourteenth day after leaving Pernambuco, the brig cast anchor off the island of Caỹenne. The entrance is beautiful. To windward, not far off, there are two bold wooded islands, called the Father and Mother ; and near thein are others, their children, smaller, though as beautiful as their parents. Another is seen a long way to leeward of the family, and scems as if it had strayed from home, and cannot find his way back. The French call it " l'enfant perdu." As you pass the islands, the stately hills on the main, ornamented with ever-verdant folinge, show you that this is by far the sublimest scencry on the sea-const, from the Amazons to the Oroonoquo. On casting your eye towards Duteh Guiana, you will see that the mountains become uncomnected, and few in number, and long before you reach Surinan, the Atlantic wave washes a flat and muddy shore.

Considerably to windward of Cayenne, and about twelve Constable leagues from land, stands a stately and towering rock, called the Constable. As nothing grows on it to tempt greedy and aspiring man to claim it as his own, the 
Second JOURNEY.

sea-fowl rest and raise their offspring there. The bird called the Frigate is ever soaring round its rugged summit. Hither the Phacton bends his rapid flight, and flocks of rosy Flamingos here defy the fowler's cuming. All along the coast, opposite the Constable, and indeed on every uncultivated part of it to windward and leeward, are seen innumerable quantities of suow-white Egrets, scarlet Curlews, Spoonbills, and Flamingos.

Colony of Cnyenne.

Cayenne is capable of being a noble and productive colony. At present it is thought to be the poorest on the coast of Guiana. Its estates are too much separated one from the other, by immense tracts of forest; and the revolutionary war, like a cold eastern wind, has chilled their zeal, and blasted their best expectations.

The clove-tree, the cinnamon, pepper and nutmeg, and many other choice spices and fruits, of the eastern and Asiatic regions, produce abundantly in Cayenne.

The town. The town itself is prettily laid out, and was once well fortified. They tell you it might easily have been defended against the invading force of the two united nations; but Victor Hugues, its governor, ordered the tri-coloured flag to be struck; and ever since that day, the standard of Braganza has waved on the ramparts of Cayenne.

Governor of He who has received humiliations from the hand of
Cayenne. this haughty, iron-hearted governor may see him now in Cayenne, stripped of all his revolutionary honours, 
broken down and ruined, and under arrest in his own house. He has four accomplished daughters, respected by the whole town. Towards the close of day, when the JOURNEY. sun's rays are no longer oppressive, these much-pitied ladies are seen walking up and down the balcony with their aged parent, trying, by their kind and filial attention, to remove the settled gloom from his too guilty brow.

This was not the time for a traveller to enjoy Cayemne. The InhaThe hospitality of the inhabitants was the same as ever, but they lind lost their wonted gaiety in public, and the stranger might read in their countenances, as the recollection of recent humiliations and misfortunes every now and then kept breaking in upon them, that they were still in sorrow for their fallen country : the victorious hostile cannon of Waterloo still sounded in their ears : their emperor was a prisoner anongst the hideous rocks of St. Helena ; and many a Frenchman who had fought and bled for France was now anongst them, begging for a little support to prolong a life which would be forfeited on the parent soil. To add another handful to the eypress and wormwood already scattered anongst these polite colonists, they had just received orders from the court of Janeiro to put on deep mourning for six months, and half-mourning for as many more, on account of the death of the queen of Portugal.

About a day's journey in the interior, is the celebrated 
Szcoso national plantation. This spot was judiciously chosen, JounNEY. for it is out of the reach of enemies' cruisers. It is called La Gabriclle. No plantation in the western world can Plantation vie with La Gabrielle. Its spices are of the choicest of La Gabrielle. kind; its soil particularly favourable to them; its arrangements beautiful; and its directeur, Monsieur Martin, a botanist of first-rate abilitics. This indefatigable naturalist ranged through the Enst, under a royal commission, in quest of botnnical knowledge ; and during his stay in the western regions, has sent over to Europe from twenty to twenty-five thousand specimens, in botany and zoology. La Gabriclle is on a fur-extending range of woody hills. Figure to yourself a hill in the shape of a bowl reversed, with the buildings on the top of it, and you will have an idea of the appearance of La Gabrielle. You approach the house through a noble avenue, five hundred toises long, of the choicest tropical fruit trees, planted with the greatest care and judgment ; and should you cliance to stray through it, after sunset, when the clove-trees are in blossom, you would fancy yourself in the Idulian groves, or near the banks of the Nile, where they were burning the finest incense, as the queen of Egypt passed.

On La Gabrielle there are twenty-two thousand clovetrees in full bearing. They are planted thirty feet asunder. Their lower branches touch the ground. In general the trees are topped at five and twenty feet high; though you will see some here towering up above sixty. The 
black pepper, the cinnamon, and nutmeg are also in great abundance here, and very productive.

While the stranger views the spicy groves of $\mathrm{La} \mathrm{Ga-}$ brielle, and tastes the most delicious fruits which have been originally imported hither from all parts of the tropical world, he will thank the government which has supported, and adınire the talents of the gentleman who has raised to its present grandeur, this noble collection of useful fruits. There is a large nursery attached to La Gabriclle, where plants of all the different species are raised and distributed gratis to those colonists who wish to cultivate them. Not far from the banks of the river Oyapoc, to windward The Cock of of Cayenue, is a mountain which contains mu immense cavern. Here the Cock of the Rock is plentiful. He is about the size of a fan-tail pigeon, his colour a bright orange, and his wings and tail appear as though fringed ; his head is ornamented with a superb double-feathery crest, edged with purple. He passes the day anid gloomy dumps and silence, and only issues out for food a short time at sunrise and sunset. He is of the gullinaceous tribe. The South-American Spaniards eall him " Gallo del Rio Negro," (Cock of the Black River,) and suppose that he is only to be met with in the vicinity of that far-inland stream; but he is common in the interior of Demerara, amongst the huge rocks in the forests of Macoushia; and he has been shot south of the line, in the captainship of Para. 
Second

JOUENEY.

The bird called by Buffon Grand Gobe-mouche has never been found in Demerara, although very common in Cayenne. He is not quite so large as the jackdaw, is entirely black, except a large spot under the throat, which is a glossy purple.

Paramaribo. You may easily sail from Cayenne to the river Surinam in two days. Its capital, Paramaribo, is handsome, rich, and populous: hitherto it has been considered by far the finest town in Guinn ; but probably the time is not fur off when the capital of Demerura may claim the prize of superiority. You may enter a creek above Paramaribo, and travel through the interior of Surinam, till you come to the Nicari, which is close to the large river Coryntin. When you have passed this river, there is a good public road to New Amsterdam, the capital of Berbice.

New On viewing New Amsterdam, it will immediately strike Amsterlum. you that something or other has intervened to prevent its arriving at that state of wealth and consequence for which its original plan shows it was once intended. What has caused this stop in its progress to the rank of a fine and populous city, remains for those to find out who are interested in it ; certain it is, that New Amsterdam has been languid for some years, and now the tide of commerce seems ebbing fist from the shores of Berbice.

Demerara. Gay and blooming is the sister colony of Demerara. 
Perhaps, kind reader, thou hast not forgot that it was from Stabroek, the capital of Demerara, that the adventurer set out, some years ago, to reach the Portuguese frontier fort, and collect the wourali poison. It was not intended, when this second sally was planned in England, to have visited Stabroek again by the route here deseribed. The plan was, to have ascended the Amazons from Para, and got into the Rio Negro, and from thence to have returned towards the source of the Essequibo, in order to examine the crystal mountains, and look once more for Lake Parima, or the White Sea; but on arriving at Cayenne, the current was rumning with such amazing rapidity to leeward, that a Portuguese sloop which had been beating up towards Para for four weeks, was then only half way. Finding, therefore, that a beat to the Amazons would be long, tedious, and even uncertain, and aware that the season for procuring birds in fine plumage had already set in, I left Cayemne in an American ship for Paramaribo, went through the interior to the Coryntin, stopped a few days in New Amsterdam, and proceeded to Demerara. If, gentle reader, thy patience be not already worn out, and thy eyes half closed in slumber, by perusing the dull adventures of this second sally, perhaps thou wilt pardon a line or two on Demerara; and then we will retire to its forests, to collect and exanine the economy of its most rare and beautiful birds, and give the world a new mode of preserving them. 
Srand Jounner.

Stabroek.

Court of justice.

The plantations.
Stabroek, the capital of Demerara, has been rapidly incrensing for some years buck; and if prosperity go hand in hand with the present enterprising spirit, Stabrock, ere long, will be of the first colonial consideration. It stands on the eastern bank at the mouth of the Demerara, and enjoys nll the udvantuges of the refreshing sea breeze; the streets are spacious, well bricked, and elevited, the trenches clean, the brilges excellent, and the houses handsome. Almost every commodity and luxury of London may be bought in the shops at Stabroek : its market wants better regulations. The hotels are commodious, clemn, und well uttended. Demerara bonsts as fine and well-disciplined militia as any colony in the western world.

The court of justice, where, in times of old, the bandage was ensily removed from the eyes of the goddess, and her senles thrown out of ecpuilibrium, now rises in dignity under the firmuess, talents, and urbanity of Mr. President Rough.

The plantations lave un appearance of high cultivntion; a tolerable iden may be forned of their value, when you know that last year Denerara numbered seventy-two thousnnd nine hundred and ninety-nine slaves. They made above forty-four million pounds of sugar, near two million gallons of rum, above eleven million pounds of coffee, and three million eight hundred and nineteen thousand five hundred and twelve 
pounds of cotton; the receipt into the publie chest wns five hundred and fifty-threc thousnud nine hundred and fifty-six puilders; the publice expenditure, four hundred and fifty-one thousund six hunded and three guilders.

Slavery cin never he defended; he whose heart is not slusery. of iron ean never wish to be nble to defend it: while he henves a sigh for the poor negro in enptivity, he wishes from his soul tlunt the truflic luel been stifled in its birth; but, unfortunutcly, the govermunents of Europe nourished it, und now that they are excrting themselves to do away the evil, and ensure liberty to the sous of Africa, the situation of the pluntention sluves is depicted as truly deplorable, and their condition wretched. It is not so. A Briton's henrt, proverbinuly kind and gencrous, is not changed by climute, or its strenums of compassion dried up by the scorehing hent of a Demerarn sun; he eheers his negroes in lubour, comforts them in sickness, is kind to them in old uge, and never forgets that they are his fellow-creatures.

Instances of cruclty und depravity certainly occur here as well an all the world over; but the edicts of the colonial government ure well calculated to prevent thein; and the British plunter, except here and there one, feels for the wrongs done to " poor ill-treated slave, and shows that his heart grieves for him by eausing immediate redress, and preventing a repetition.

Long unay ye flourish, penceful and liberal inhabitants 
Second JOURNRY.

of Demerara. Your doors are ever open to harbour the harbourless; your purses never shut to the wants of the distressed : many a ruined fugitive from the Oroonoque will bless your kindness to him in the hour of need, when flying fiom the woes of eivil discord, withont food or raiment, he begged for shelter underneath your roof. The poor sufferer in Trinidad, who lost his all in the devouring flames, will remember your chnrity to his latest moments. The traveller, as he leaves your port, casts a longing, lingering look behind; your nttentions, your hospitality, your pleasantry and mirth are uppermost in his thonghts; your prosperity is elose to his heart. Let us now, gentle reader, retire from the 'busy seenes of man, and journey on towards the wilds in quest of the feathered tribe.

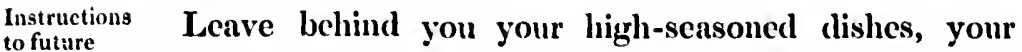
adventurers. wines, and your delieacies ; carry nothing but what is necessary for your own comfort, and the object in view, and depend upon the skill of an Indian, or your own, for fish and game. A slicet, about twelve feet long, ten wide, painted, and with loop-holes on ench side, will be of grent service : in a few minutes you can suspend it betwixt two trees in the shape of a roof. Under this, in your hammock, you may defy the pelting shower, and sleep heedless of the dews of night. A hat, a shirt, and a light pair of trowsers, will be all the raiment you require. Custom will soon tench you to tread lightly 
and barefoot on the little inequalities of the ground, and show you how to pass on, unwounded, amid the mantSecond ling briars.

Snakes, in these wilds, are certainly an amnoyance, snakes. though perhaps more in imngination thim in reality; for you must recollect that the serpent is never the first to offend: his poisonous fang was not given him for conquest : he never inflicts a wound with it, but to defend existence. Provided you walk cautiously, and do not absolutely touch him, you may pass in safety close by him. As he is often coiled up on the ground, and amongst the branches of the trees above you, a degree of circumspection is neessary, lest you unwarily disturb him.

'Tigers are too few, and too apt to fly before the noble Tigers. face of man, to require a moment of your attention.

The bite of the most noxious of the insects, at the very worst, only causes a transient fever, with a degree of pain more or less.

Birds, in general, with n few exceptions, are not com- Birls. mon in the very remote parts of the forest. The sides of rivers, lakes, and ereeks, the borders of savamns, the old abundoned habitations of lndians, and wood-cutters, seem to be their favourite haunts.

A

'Though least in size, the glittering mantle of the Hum- Hummingming-bird entitles it to the first place in the list of the birds of the new world. It may truly be colled the bird 
Second JOURNEY. the Huwning-birds. of paradise ; and had it existed in the old world, it would have claimed the title instead of the bird which has now the honour to bear it:-see it darting through the air almost as quick as thought! -now it is within a yard of your face!-in an instant gone!-now it flutters from flower to flower to sip the silver dew-it is now a ruby-now a topaz-now an emerald-now all burnished gold! It would be arrogant to pretend to describe this winged gem of nature after Buffon's elegant deseription of it.

Cayenne and Demerara produce the same liummingbirds. Perhaps you would wish to know something of their haunts. Chiefly in the months of July and August the tree called Bois Immortel, very common in Demerara, bears abundance of red blossom, which stays on the tree for some weeks; then it is that most of the different species of humming-birds are very plentiful. The wild red sage is also their favourite shrub, and they buzz like bees round the blossom of the Wallaba tree. Indeed, there is searce a flower in the interior, or on the seacoast, but what receives frequent visits from one or other of the species.

On entering the forests, on the rising land in the interior, the blue and green, the smallest brown, no bigger than the humble bee, with two long fenthers in the tail, and the little forked-tail purple-throated humming-birds, glitter before you in ever-ehanging attitudes. One 
species alone never shows his beauty to the sun; and were it not for his lovely shining colours, you might almost be tempted to elass him with the goat-suckers, on aceount of his habits. He is the largest of all the humming-birds, and is all red and changing gold green, exeept the head, which is black. He has two long feathers in the tail, which cross each other, and these have gained him the name of Karabimiti, or Ara humming-bird, from the Indians. You never find him on the seacoast, or where the river is salt, or in the heart of the forest, unless fresh water be there. He keeps close by the side of woody fresh-water rivers, and dark and lonely ereeks. He leaves his retreat before sunrise to feed on the insects over the water; he returns to it as soon as the sun's rays cause a glare of light, is sedentary all day long, and comes out again for a short time after sunset. He builds his nest on a twig over the water in the unfrequented erceks; it looks like tammed cow leather.

As you advance towards the mountains of Demerara, other species of humming-birds present themselves before you. It seens to be an crroneous opinion, that the humming-bird lives entirely on honey-dew. Almost every flower of the tropical elimates contains inseets of one kind or other; now, the humming-bird is most busy about the flowers an hour or two after sunrise, and after a shower of rain, and it is just at this time that the inseets come out to the edge of the flower in order that Q 2 
Secoso the sun's rays may dry the nocturnal dew and rain which Joursey. they have received. On opening the stomach of the humming-bird, dead inseets are almost always found there.

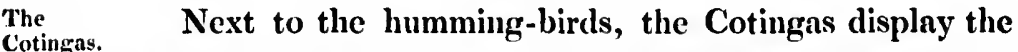
gayest plumage. They are of the order of passer, and you number five species betwixt the sencoast and the rock Saba. Perhaps the scarlet Cotinga is the richest of the five, and is one of those birds which are found in the deepest recesses of the forest. His erown is flaning red; to this abruptly succeeds a dark shining brown, reaching lialf way down the back : the remainder of the back, the rump, and tail, the extremity of which is edged with black, are a lively red; the belly is a somewhat lighter red; the breast reddish black; the wings brown. He has no song, is solitary, and utters a monotonous whistle which souncls like "quet." He is fond of the sceds of the Hitia tree, and those of the Siloabali and bastard Siloabali trees, which ripen in December, and continue on the trees for above two months. He is found throughont the year in Demerarn; still notling is known of his incubation. The Indians all agree in telling you that they have never seen his nest.

The purpie. The purple-breasted Cotinga has the throat and breast bratated
Cotingal. of a deep purple, the wings and tail black, and all the rest of the body a most lovely shining blue.

The purple-throated Cotinga has black wings and tail, 
and every other part a light and glossy blue, save the throat, which is purple.

The Pompadour Cotinga is entirely purple, except The Pompahis wings, which are white, their four first feathers tipped tinga. with brown. The great coverts of the wings are stiff, narrow, and pointed, being shaped quite different from those of any other bird. When you are betwixt this bird and the sun, in his flight, he appears uncommonly brilliant. He makes a hoarse noise, which sounds like "Wallnbaba." Hence his name amongst the Indians.

None of these three Cotingas liave a song. They feed on the Hitia, Siloabali, and bastard Siloabali seeds, the wild Guava, the fig, and other fruit trees of the forest. They are easily shot in these trees during the months of December, Januar, and part of February. The greater part of them disappear after this, and probably retire far away to breed. Their nests have never been found in Demerara.

The fifth species is the celebrated Campanero of the The CamSpaniards, ealled Dara by the Indians, and bell-bird by pamero. the English. He is about the size of the Jay. His plumage is white ns snow. On his forchead rises a spiral tube nearly three inches long. It is jet black, dotted all over with small white feathers. It has a communication with the palate, and when filled with air, looks like a spire; when empty, it becomes pendulous. His note is loud and clear, like the sound of a bell, and may be heard at the 
Szcons distance of three miles. In the midst of these extensive JouRnEY. wilds, generally on the dried top of an aged Morn, almost out of gum reach, you will see the Campanero. No sound or song from any of the winged inhabitants of the forest, not even the clearly pronounced " Whip-poor-Will," from the goatsucker, cause such astonishment, as the toll of the Campinero.

With many of the feathered race, he pays the common tribute of a morning and an evening song; and even when the meridian sun has shut in silence the mouths of almost the whyt? of animated nature, the Campanero still cheers the forcst. You hear his toll, and then a pause for a minute, then another toll, and then a pause again, and then a toll, and again a pause. Then he is silent for six or eight minutes, and then another toll, and so on. Acteon would stop in mid chase, Maria would defer her evening song, and Orpheus himself would drop his lute to listen to him; so sweet, so novel, and romantic is the toll of the pretty snow-white Campanero. He is never seen to feed with the other Cotingas, nor is it known in what part of Guiana he makes his nest.

The'Toucan. While the Cotingas attract your attention by their superior plumage, the singular form of the Toucan makes a lasting impression on your memory. There are three species of Toucans in Demerara, and three diminutives, which may be called Toucanets. The largest of the first species frequents the Mangrove trees on the sea-coast 
He is never seen in the interior till you reach Macoushia, where he is found in the neighbourhood of the river Tacatou. The other two species are very common. They JUURNEY. feed entirely on the fruits of the forest, and though of the pie kind, never kill the young of other birds, or touch carrion. The larger is ealled Bouradi by the Indians, (which means nose,) the other, Scirou. They seem partial to each other's company, and often resort to the same feeding tree, and retire together to the same shady noon-day retreat. They are very noisy in rainy weather at all hours of the day, and in fair weather, at morn and eve. The sound which the Bouradi makes, is like the elear yelping of a puppy dog, and you fimey he says " pia-po-o-co," and thus the South American Spaniurds call him Piapoco.

All the Toueanets feed on the same trees on which the Toucan feeds, and every species of this family of enormous bill, lays its eggs in the hollow trees. They are social, but not gregarious. You may sometimes see cight or ten in company, and from this you would suppose they are gregarious; but, upon a closer examination, you will find it has only been a dinner party, which breaks up and disperses towards roosting time.

You will be at a loss to conjecture for what ends nature has overloaded the hend of this bird with such an enormous bill. It cannot be for the offensive, as it has no need to wage war with any of the tribes of animated 
Skcows nature ; for its food is fruits and seeds, and those are in JoUaxBY. superabundance throughout the whole year in the regions where the Toucun is found. It can hardly be for the defensive, as the Toucan is preyed upon by no bird in South America, and were it obliged to be at war, the texture of the bill is ill adipted to give or receive blows, as you will see in dissecting it. It cannot be for any partieular protection to the tongue, as the tongue is a perfect feather.

Its flight. The Hight of the Touean is by jerks; in the action of flying it seems incommoded by this huge disproportioned feature, and the head seems us if bowed down to the earth by it against its will; if the extraordinary form and size of the bill expose the 'Toucan to ridicule, its colours make it amends. Were a specimen of each species of the Toucan presented to you, you would pronounce the bill of the Bouradi the most rich and beautiful; on the ridge of the upper mandible a broad stripe of most lovely yellow extends from the head to the point; a stripe of the same breadth, though somewhat deeper yellow, falls from it at right angles next the head down to the edge of the mandible; then follows a black stripe, half as broad, falling at right angles from the riclge, and rumning narrower ulong the edge to within half an inch of the point. The rest of the mandibie is a deep bright red. The lower mandible has no yellow: its black and red are distributed in the same manner as on the upper one, 
with this difference, that there is black aloout an inch from the point. The stripe corresponding to the deep yellow stripe on the upper mandible is sky blue. It is worthy of remark that all these brilliant colours of the bill are to be found in the plumage of the body, and the bare skin round the eye.

All these colours, exeept the blue, are inherent in the horn; that part which appears blue is in reality transparent white, and receives its colour from a thin piece of blue skin inside. This superb bill fades in death, and in three or four days' time, has quite lost its original colours.

Till within these few years, no iden of the true colours of the bill could be formed from the stuffed Toucans brought to Europe. About eight ycars ago, while eating a boiled Toncan, the thought struck me that the colours in the bill of a preserved speeimen might be kept as bright as those in life. A series of experiments proved Preserves a this beyond a doubt. If you take your pen-knife and Toucan. cut awny the roof of the upper mandible, you will find that the space betwixt it and the outer shell contains a large collection of veins, and small osscous fibres rumning in all clirections through the whole extent of the bill. Clear away all these with your knife, and you will come to n substance more firm than skin, but of not so strong a texture as the horn itself; cut this away also, and behind it is discovered a thin and tender membrane; 
Sacosp yellow, where it has touched the yellow part of the horn; Jounsar. blue, where it has touched the red part, and black towarls the elge and point; when dried, this thin and tender membrane becomes nearly black; as soon as it is cut away, nothing remains but the outer horn, red and yellow, and now become transparent; the under mandible inust undergo the same operation. Grent care must be taken, and the knife used very cautiously, when you are cutting through the different parts close to where the bill joins on to the head; if you cut away too much, the bill drops off ; if you press too hard, the knife comes through. the horn; if you lenve too great a portion of the membrane, it appears through the horn, and by becoming black when dried, makes the horn appear black also, and has a bad effect; judgment, caution, skill, and practice, will ensure success.

You have now cleared the bill of all those bodies which are the cause of its apparent fading; for, as has been said before, these bodies dry in cleath, and become quite discoloured, and appear so through the horn; and reviewing the bill in this state, you conclude that its former bright colours are lost.

Something still remains to be done. You have rendered the bill transparent by the operation, and that transparency inust be done away to make it appear perfectly natural. Pound some clean chalk, and give it enough water till it be of the consistency of tar; add a 
proportion of gum arabic to make it adhesive; then take a camel-hair brush, and give the inside of both mandibles a coat; apply a second when the first is dry, then another, and a fourth to finish all. The gum arabic will prevent the chalk from cracking and falling off. If you remember, there is a little space of transparent white in the lower mandible, which originally appeared blue, but which became transparent white as soon as the thin piece of blue skin was cut away; this must be painted blue inside. When all this is completed, the bill will please you ; it will appear in its original colours. Probably your own abilities will suggest a cleverer mode of operating than the one here described. A small gouge would assist the penknife, and render the operntion less difficult.

The Houtou ranks high in beauty anongst the birds The Houof Demerara; his whole body is green, with a bluish cast in the wings and tail; his crown, which he erects at pleasure, consists of black in the centre, surrounded with lovely blue of two different shades : he has a triangular black spot, edged with blue, behind the eye, extending to the ear; and on his breast a sable tuft, consisting of nine feathers edged also with blue. This bird seems to suppose that its beauty can be increased by trimming the tail, which undergoes the same operation as our hair in a barber's shop, only with this difference, that it uses its own beak, which is serrated, in 
Szcovo lien of a pair of scissars: as soon ns his tail is full Jounser. grown, he begins about an inch from the extremity of the two longest feathers in it, nud ents awny the web on both sides of the shaft, making a gap about an inch long: both mule and female Adonise their tails in this munner, which gives them n remurkuble uppenrunce mmongst all other birds. While we consider the tuil of the Houtou blemished und defective, were he to come amongst us, he would probably consider our heads, eropped and bald, in no better light. He who wishes

Its haunts. to observe this hundsome bird in his native linunts, must be in the forest nt the morning's duwn. The Houtou shums the society of man : the pluntutions and cultivnted parts are too much disfurbed to engnge it to settle there; the thick and gloomy forests are the places preferred by the solitury Houtou. In those furextending wilds, about daybrenk, you henr him articulate, in a distinct und mournful tone, "Houtou, houton." Move cautious on to where the sound procecds from, and you will see him sitting in the underwood, about a couple of yurds from the ground, his tail moving up and (lown every time he articulates " houtou." He lives on insects and the berries umongst the underwood, minl very rarely is seen in the lofty trees, except the bastard Siloabali-trec, the fruit of which is grateful to him. He mukes no nest, but rears lis young in a hole in the sand, generally on the side of $\mathbf{n}$ hill. 
While in quest of the Houtou, you will now and then fall in with the jay of cinium, culled by the Indians Ibibirou. Its forchend is bluck, the rest of the hend Gulana. white; the throut and brenst like the Euglish magpie: about an inch of the extremity of the tril is white, the ot leer part of it, together with the lonck and wings, a grayish changing purple; the belly is white: there are generally six or eight of the'm in compuny; they are shy and garrulons, and tarry a vory short time in one place : they are never seen in the cultivated purts.

Through the whole cextent of the forest, chiefly from sumrise till nine o'clock in the morning, you hear a sound of "wow, wow, wow, wow." 'l'his is the bird called Boe- The Boelorn by the Indinns, It is sumuller than, the common pigeon, and seems, in some mensure, to partake of its unture; its hend and herent are blue; the back and rump somewhint rescumble the colour on the peneock's neck; its loclly is a brighit yellow; the legs ure so very small that it always n!peen's as if sitting on the branch; it is as ill mapted for wrilking as the swallow; its neck, for above an incls nll rouns, is cuite bare of fenthers; but this deficiency is not secen, for it always sits with its head drawn in "1pon its shoulders: it sometimes feeds with the Cotingas on the (innven and Hitin trees; but its chicf intriment seens to loe insects, and, like most birds "It follow this prey, its ('hnps are well armed with 1ristles: it is fomsl in Dennerum at all times of the 
Secons year, and makes a nest resembling that of the stock JounNey. dove. This bird never takes long flights, and when it crosses a river or creek it goes by long jerks.

The Boclorn is very unsuspicious, appearing quite heedless of danger: the report of a gun within twenty yards will not cause it to leave the branch on which it is sitting, and you may often approach it so near as almost to touch it with the end of your bow. Perhaps there is no bird known whose feathers are so slightly fixed to the skin as those of the Boclora. After shooting it, if it touch a branch in its descent, or if it drop on hard ground, whole heaps of feathers fall off : on this account it is extremely lard to procure a specimen for preservation. As soon as the skin is dry in the preserved specimen, the feathers becomr as well fixed as those in any other bird.

The Cuia. Another species, larger than the Boclora, attracts much of your notice in these wilds; it is called Cuia by the Indians, from the sound of its voice; its habits are the stume as those of the Boclora, but its colours different ; its liend, breast, back, and rump are a shining, changing green; its tail not quite so bright ; a black bar runs across the tail towards the extremity, and the outside feathers are partly white as in the Boclora; its belly is entirely vermilion, a bar of white separating it from the green on the breast.

There are diminutives of both these birds; they have 
the same habits, with a somewhat different plumnge, and about half the size. Arrayed from head to tail in a robe of richest sable lue, the bird called Rice-bird loves spots $\begin{aligned} & \text { The Rice- } \\ & \text { Bird. }\end{aligned}$ cultivated by the hand of man. The woodeutter's house on the lills in the interior, and the plauter's liabitation on the sea-const, equally attract this songless species of the order of Pie, provided the Indian corn be ripe there. He is nearly of the jackdaw's size, and makes lis nest far away from the haunts of men; le may truly be ealled a blackbird: independent of his plumage, his beak, inside and out, his legs, his toes, and claws are jet black.

Mankind, by clearing the ground, and sowing a variety of seeds, induces many kinds of birds to leave their native haunts, and come and settle near him : their little depredations on his sceds and fruits prove that it is the property, and not the proprietor, which has the attrnctions.

One bird, however, in Demerara is not actuated by The Casselfish motives; this is the Cassique; in size, he is larger than the starling; he courts the socicty of man, but disdains to live by his labours. When nature ealls for support, he repairs to the neighbouring forest, and there partakes of the store of fruits and seeds, which she las produced in abundance for her aërial tribes. When his repast is over, he retums to man, and pays the little tribute which he owes him for his protection; he takes his 
station on a tree elose to his house; and there, for hours together, pours forth a succession of imitative notes. His own song is sweet, but very short. If a Toucan be yelping in the neighbourhood, he drops it, and imitates him. Then he will amuse his protector with the cries of the lifferent species of the woodpecker; and when the sheep bleat, he will distinctly answer them. Then comes his own song again, and if a puppy dog, or a Guinea fowl interrupt him, he takes them off admirably, and by his different gestures during the time, you would conclude that he enjoys the sport.

The Cassigue is gregarious, and imitates any sound he hears with such exactness, that he goes by no other name than that of Mocking bird amongst the colonists.

At breeding time, a number of these pretty choristers resort to a tree near the planter's house, and from its outside branches weave their pendulous nests. So conscious do they seem that they never give offence, and so little suspicions are they of receiving any injury from man, that they will choose a tree within forty yards from his house, and occupy the brinches so low down, that he may peep into the nests. A tree in Waratilla Creek affords a proof of this.

The proportions of the Cassique are so fine, that he may be said to be a model of symmetry in ornithology. On each wing he has a bright yellow spot, and his rump, belly, and half the tail, are of the same colour. All.the 
rest of the body is black. His bank is the colour of sulphur, but it fades in death, and requires the same operation as the bill of the Toucan to make it keep its colours. Up the rivers, in the interior, there is another Cassique, nenrly the same size, and of the same habits, though not gifted with its powers of imitation. Except in breeding time, you will see hundreds of them retiring to roost, amongst the Moca-moea-trees and low shrubs on the banks of the Demerara, after you pass the first island. They are not common on the sea-coast. The rump of this Cassique is a flaming scarlet. All the rest of the body is a rich glossy black. His bill is sulphur colour. You may often see numbers of this species weaving their pendulous nests on one side of a tree, while numbers of the other species are busy in forming theirs on the opposite side of the same tree. Though such near neighbours, the females are never observed to kick up n row, or come to blows!

Another species of Cassique, as large as a crow, is very Another common in the plantations. In the morning, he generally the Cassique repairs to n large tree, and there with his tail spread over his back, and shaking his lowered wings, he produces notes, which thongh they cannot be said to amount to a song, still have something very sweet and pleasing in them. He makes his nest in the same form as the other Cassiques. It is above four feet long; and when you pass under the tree, which often contains fifty or sixty of 
SEcond JOURNEY.

them, you eannot help stopping to admire them as they wave to and fro, the sport of every storm and breeze. The rump is chestnut; ten feathers of the tail are a fine yrllow, the remaining two, which are the middle ones, are blacki, and an inch shorter than the others. His bill is sulphur colour; all the rest of the body black, with here and there shades of brown. He has five or six long narrow black feathers on the back of his head, which ho erects at pleasure.

There is one more species of Cassique in Demerara, which always prefers the forests to the eultivated parts. His economy is the same as that of the other Cassiques. He is rather sinaller than the last described bird. His body is greenish, and his tuil and rump paler than those of the former, Half of his beak is red.

Wood-
peckers. You would not be long in the forests of Demerara, without noticing the Woodpeckers. You meet with them feeding at all hours of the day. Well may they do so. Were they to follow the eximple of most of the other birds, and only feed in the morning and evening, they would be often on short allowance, for they sometimes have to labour three or four hours at the tree before they get to their food. The sound which the largest kind makes in hammering against the bark of the tree, is so lond, that you would never suppose it to proceed from the efforts of a bird. You would take it to be the woodman, with his axe, trying by a sturdy blow, often repeated, 
whether the tree were sound or not. There are fourteen species liere; the largest the size of a magpie, the smallest no bigger than the wren. They are all beautiful ; and the greater part of them have their heads ornamented with a fine crest, movable at pleasure.

It is said, if you once give a dog a bad name, whether innocent or guilty, he never loses it. It sticks close to him wherever he goes. He has many a kick, and many a blow to bear on account of it; and there is nobody to stand up for him. The Woodpecker is little better off. The proprietors of woods, in Europe, have long accused him of injuring their timber, by boring looles in it, and letting in the water, which soon rots it. The colonists in America have the same complaint against him. Had he the power of speech, which Ovid's birds possessed in days of yore, he could soon make a defence. "Mighty lord of the woods," he would sily to man, "why do you wrongfully accuse me? Why do you lumt me up and down to denth, for an imaginary offence? I have never spoiled a leaf of your property, much less your wood. Your merciless shot strikes me, at the very time I am doing you a service. But your shortsightedness will not let you sce it, or your pride is above examining closely the actions of so insignificant a little bird as I am. If - there be that spurk of feeling in your breast, which they say man possesses, or ought to possess, above all other animnls, do a poor injured creature a little kinduess, and 
Second JOURNEY.

watch ine in your woods only for one day. I never wound your healthy trees. I should perish for want in the attempt. The sound bark would easily resist the force of my bill, and were I even to pieree through it, there would be nothing inside that I could fancy, or my stomach digest. I often visit them it is true, but a knock or two convince ine that I must go elsewhere for support ; and were you to listen attentively to the sound which iny bill causes, you would know whether I am upon a healthy, or au umhealthy trec. Wood and bark are not my food. I live entirely upon the insects which have already formed a lodgement in the distempered tree. When the sound informs me that my prey is there, I labour for hours together, till I get at it ; and by consuming it, for my own support, I prevent its further depredation:; in that part. Thus I discover for you your hidden and unsuspected foc, which has been devouring your wood in such secrecy, that you had not the least suspicion it was there. The hole which I make, in order to get at the pernicious verinin, will be seen by you as you pass under the tree. I leave it as a signal to tell you, that your tree has already stood too long. It is past its prime. Millions of insects, engendered by disease, are preying upon its vitals. Ere long it will fall a log in useless ruins. Wamed by this loss, cut down the rest in time, and spare, $O$ spare, the unoffending Woodpecker.'"

The King- In the rivers, and different creeks, you number six 
species of the King-fisher. They make their nest in a hole in the sand on the side of the bank. As there is SEcond always plenty of foliage to protect them from the heat of the sum, they feed at all hours of the day. Though their plumage is prettily varied, still it falls far short of the brillianey displnyed by the English king-fishes. This little native of Britain would outweigh them altogether in the scale of beauty.

A bircl ealled Jacamar is often taken for $\mathbf{n}$ king-fisher, The Jacabut it has no relationship to that tribe; it frequently sits in the trees over the water, and as its beak bears some resemblanee to that of the king-fislier, this may probably account for its being taken for one; it feeds entirely upon insects; it sits on a branch in motionless expectation, and as soon as a fly, butterfly, or moth pass by, it darts at it, and returns to the branch it had just left. It scems an indolent, seclentary bird, shumning the society of all others in the forest. It never visits the plantations, but is found at all times of the year in the woods. There are four species of Jacamar in Demerara; they are all beautiful; the Iargest, rich and superb in the extreme. Its plunnage is of so fine a changing blue and golden gree:, that it may be ranked with the choiest of the humming-birds. Nature has denied it a song, but given a costly garment in lien of it. The smallest species of Jacamar is very common in the dry savammas. The second size, all golden green on the back, must be looked 
SAcOND JUURXEY,

The Troupiale. ol'l'rollpiale.

for in the Wallaba forest. The third is found throughout the whole extent of these wilds : and the fourth, which is the largest, frequents the interior, where you begin to perceive stones in the ground.

When you huve penetrated fur into Macoushia you hear the pretty songster, called Troupiale, pour forth a variety of swcet and plaintive notes. This is the bird which the Portuguese call the nightingale of Guiana ; its predominant colours are rich orange, and shining black, arrayed to great advantage : his delicate and well-shaped frame seems unable to bear euptivity. The Indians sometimes bring down Troupiales to Stabroek, but in a few montlis they languish and die in a cage. They soon become very familiar; and if you allow them the liberty of the house, they live longer than in a cage, and uppear in better spirits; but, when you least expect it, they drop down and die in epilepsy.

Smaller in size, and of colour not so rich, and somewhat differently arranged, imother species of Troupiale sings melodionsly in Demerara. The woodcutter is particularly fuvcured by him ; for while the hen is sitting on her nest, built in the roof of the woodcutter's house, he sings for hours together close by : he prefers the forests to the cultivated parts.

Thirl spe- You would not grudge to stop for a few minutes, as piale.
you are walking in the plantations, to observe a third species of 'Troupiale: his wings, tail, and throat are 
black, ull the rest of the body is a bright yellow. There is something very sweet and plaintive in his song, though much shorter than that of the Troupinle in the interior.

A fourth specier $r$ res in flocks from place to place in Fourth spethe cultivated parts at the time the Indiau coln is ripe; piule he is all black, except the head and throat, which are yellow ; his attempt at song is not worth attending to.

Wherever there is a wild fig-tree ripe, a numernus spe- Tungara cies of bircls, called Tangara, is sure to be on it. There are eighteen beatiful species here. Their plumage is very rich and diversified; some of them boast six scparate colours; others have the blue, purple, green, and black so kindly blended into each other, that it would he impossible to mark trieir boundaries; while others again exhibit them strong, distinct, and abrupt : many of these Tungurns have a fine song. They seem to partake much of the nature of our linnets, sparrows, and finches. Some of them are fond of the plantations; others are never seen there, preferring the wild seeds of the forest to the choicest fruits planted by the haud of inan.

On the same fig-trees to which they repair, and often Manikin accidentally up and down the forest, you fall in with four species of Manikin. The largest is white and black, with the feathers on the throat remarkably long: the next in size is half red and half black : the third, black, with a white crown: the fourth, black, with a golden crown, and red. feathers at the knee. The half red. 
SkCond JounNKY.

The small Tiger-bird.

The Yawaraciri. nud half bluck species is the scarenst. There is a creek in the Demerurn culled Cumouni. Alout ten minntes from the mouth, you see n common-sized fig-tree on your right-lund, ns you uscend, hanging over the whter; it bears a very smull fig twice a year. When its fruit is ripe, this Mnnikin is on the tree from morn till eve.

On all the ripe fig-trees in the forest you see the bird ealled the small Tiger-bird. Like some of our belles and dandies, it has a gaudy vest to veil an ill-shuped body: the throat, and part of the head, ure a bright red; the breast and belly 'ove black spots on a yellow ground; the wings are a dark green, black, and white; and the rump and tnil black and green. Like the Manilin it has no song: it depends solely upon a slıowy garment for admiration.

Devoid too of song, and in a still superber garb, the Yawaraciri comes to feed on the same tree. It has a bar like black velvet from the eyes to the beak; its legs are yellow ; its throat, wings, and tail black; all the rest of the body a charming blue. Chiefly in the dry savnnnas, and here and there accidentally in the forest, you see a songless Yawaraciri still lovelier than the last : his crown is whitish blue, arrnyed like a cont of mail; his tail is black, his wings black and yellow; legs red; and the whole body a glossy blue. Whilst roving through the forest, ever and anon you see individuals of the wren 
species, busy anongst the fallen leaves, or seeking insects at the roots of the trees.

Here, too, you find six or seven species of small birds, whose backs appear to be overlonded with silky plumage. One of these, with a chestnut brenst, smoke-coloured back, tail red, white fenthers like horns on his hend, and white, narrow-pointed feathers under the jaw, feeds entirely upon ants. When a nest of large, light, brown nnts emigrates, one following the other in meandering lines above a mile long, you see this bird watehing them, and every now and then picking them up. When they disappear, he is seen no more : perhups this is the only kind of ant he is fond of : when these ants are stirring, you are sure to find him near them. You camot well mistake the ant after you have once been in its com- Ants. pany, for its sting is very severe, and you can hardly shoot the bird, and pick it up, without having five or six upon you.

Parrots and Paroçuets are very numerous here, and of Parrots and many different kinds. You will know when they are nenr you in the forest, not only by the noise they make, but also by the fruits and seeds which they let fall while they are feeding.

The Hia-hia parrot, ealled in England the parrot of The Hiathe sun, is very rerarkable : he can ereet at pleasure a fine radiated circle of tartan feathers quite round the back of his head from jaw to jaw. The fore part of his 
Srcoso head is white; his back, tail, und wings, green ; and his Jounsey. brenst aud belly tartuu.

The Ara. Superior in size and beauty to every parrot of Sonth Americn, the Ara will force you to take your eyes from the rest of animated nuture, and gaze at him : his communding strength, the flaming scarlet of his body, the lovely vuriety of red, yellow, blue, and green in his wings, the extranordinary length of his scarlet and blue tril, seem all to join and demand for him the title of cimperor of all the parrots. He is scarce in Demerara till you reach the confines of the Macoushi country; there he is in vast abundance; he mostly feeds on trees of the palm species. When the Concourite trees have ripe fruit on them, they are covered with this mugnificent parrot : he is not shy or wary; you may take your blowpipe and quiver of poisoned arrows, and kill more than you are able to eary back to your hut. They nre very vociferous, and, like the common parrots, rise up in bodies towinds sunset, and fly two and two to their place of rest. It is a grand sight in olnithology to sce thousands of Arns flying over your hend, low enough to let you have a full view of their flaming mantle. The Indians find their flesh very good, and the feathers serve for ormaments in their head-dresses. They breed in the holes of trees, are easily reared und tamed, and learn to speak pretty distinctly.

Another species frecuents the low lands of Demerara. 
He is nearly the size of the scarlet Arn, but much inferior in plumage. Blue and yellow me his predominant colours.

Along the creeks und river sides, and in the wet savamns, six species of the Bittern will engnge your attention. They ure ull lumulsome. The smuliest not so large as the kinglishl wuter-he'll.

In the savumus too, you will soinctimes surprise the $\begin{gathered}\text { The snow- } \\ \text { white }\end{gathered}$ snow-white ligrette, whose buek is mlorned with the Egrette. phumes from which it tuken its mune. Here too the spurwinged Water-hen, the blue and green Water-hen, and two other species of ordinn'y plumnge, are found. While in equest of these, the lolue Heron, the large and small brown Heron, the Boutbill, und Muscovy Duck, now and then rise up before you.

When the stm hans sunk in the western woods, no longer agitated by the breear: when you cin only see a straggler or two of the fentheresl tribe hastening to join its mate, already at its roosting plun'e, the'n it is that the Gont- The Goutsucker comes out of' the loresest, where it has sat all day long in shmbering cinso, unmindfiul of the gay and busy scenes around it. Its cyess nire 100 delicately formed to bear the light, and thus it is forecel to shm the fluming face of day, and wait in putienee till night invites him to partake of the plensures her dusky presenee brings.

The harmless, unoflenting (iontsucker, firom the time of Aristotle down to the present day, has been in disgrace 
Secown with man. Futher has handed dowi to son, and author Joukser. to author, that this nocturnal thief subsists by milking the flocks. Poor injured little bird of night, how sadly hast thou suffered, and how foul a stain has inattention to facts put upon thy character! Thou hast never robbed man of any part of his property, nor deprived the kid of a drop of milk.

When the moon shines bright, you may have a fnir opportunity of examining the Goatsucker. You will sec it close by the cows, goats, and sheep, jumping up every now and then, under their bellies. Approach a little nearer,- he is not shy, " he fears no danger, for he knows no sin." See how the noeturnal flies are tormenting the herd, and with what dexterity he springs up and catehes them, as fast as they alight on the belly, legs, and udder of the animals. Observe how quiat they stand, and how sensible they secm of his good oflices, for they neither strike at hiv, nor hit him with their tail, nor tread on him, nor try to drive him away as an uncivil intrueler. Were you to dissect him, and inspect his stomach, you would find no milk there. It is full of the flies which have been annoying the herd.

Itsplumage. 'The prettily mottled plumage of the Goatsucker, like that of the owl, wants the lustre which is observed in the feathers of the birds of day. This, at once marks him as a lover of the pale moon's nightly beams. There are nine species here. 'The largest appears nearly the size of the 
English wood owl. Its ery is so remarkable, that having once heard it you will never forget it. When night reigns over these immeasurable wilds, whilst lying in your hammock, you will hear this Goatsucker lamenting like one in deep distress. A stranger would never conceive it to be the ery of a bird. He would say it was the departing voice of a midnight murdered vietim, or the last wailing of Niobe for her poor children, before she was turned into stone. Suppose yourself in hopeless sorrow, begin with a high ioud note, and pronounce, "ha, ha, ha, ha, ha, ha, ha," each note lower and lower, till the last is scarcely heard, pausing a moment or two betwixt every note, and you will have some idea of the moming of the largest Goatsucker in Demerara.

Four other species of the Goatsucker articulate some words so distinctly, that they have received their names from the sentences they utter, and absolutely bewilder the stranger on his arrival in these parts. The most common one sits down elose by your door, and flies, and alights three or four yards before you, as you walk along the road, crying, " Who-are-you, who-who-who-are-you." Another bicls you, " Work-away, work-work-work-away." $\Lambda$ third eries, mournfully, " Willy-come-go. Willy-WillyWilly-come-go." And high up in the country, a fourth tells yon to " Whip-poor-Will. Whip-whip-whip-poor-Will."

You will never persuade the negro to clestroy these birds, or get the Indian to let fly his arrow at them. They 
SECond JOURNEY.

are birds of omen, and reverential clread. Jumbo, the demon of Africa, has them under his command; and they equally obey the Yabahou, or Demerara Indian devil. They are the receptacles for departed souls, who come back again to earth, umable to rest for crimes done in their digs of nature; or they are expressly sent by Jumbo, or Yabahou, to haunt cruel and hard-hearted masters, and retaliate injuries received from them. If the largest Goatsucker chance to ery near the white man's door, sorrow and grief will soon be inside; and they expect to see the master waste away with a slow consuming sickness. If it be heard close to the negro's or Indian's hut, from that night misfortme sits brooling over it ; and they await the event in terrible suspense.

You will forgive the poor Indian of Guiana for this. He knows no better; he has nobody to teach lim. But shame it is, that in our own civilized country, the black eat and broomstaff should be considered as conductors to and from the regions of departed spirits.

Ancedote. Many years ago I knew poor harmless Mary; old age had maked her strongly, just as he will mark you and me, should we arrive at her years and earry the weight of grief which bent her clouble. The old men of the village said she had been very pretty in her youth; and nothing could be seen more comely than Mary when she danced on the green. He who had gained her heart, left her for another, less fair, though richer than Mary. 
From that time she becime sad and pensive; the rose left her cheek. and she was never more seen to dance round the May-pole on the green : her expectations were blighted; she became quite indifferent to every thing around her, and seemed to think of nothing but how she could best attend her mother, who was lame, and not long for this life. Her mother had begiged a black kitten

- from some hoys who were going to drown it, and in her last illness she told Mary to be kind to it for her sake.

When age and want had destroyed the symmetry of Mary's fine form, the village began to consider her as one who had dealings with spirits; her cat confirmed the suspicion. If a cow died, or a villager wasted away with an unknown complaint, Mary and her cat had it to answer for. Her broom sometimes served her for a walking-stick; and if ever she supported her tottering frame with it as far as the May-pole, where once, in youthful bloom and beanty, she had attracted the eyes of all, the boys woulci surround her, and make sport of her, while her cat had neither friend nor safety heyond the cottage wnll. Nobody considered it crucl or uncharitable to torment a witch; and it is probable, long before this, that eruelty, old age, and want, have worn her out, and that both poor Mary and her eat have ceased to be.

Would you wish to pursue the diflerent species of game, well stored and boundless is your range in Demerara. Here no one dogs you, and afterwards clandes- 
Secons tinely inquires if you have a hundred a year in land to JOURNEY.

entitle you to cnjoy such patrician sport. Here no saney intruder asks if you have taken out a license, by virtue of which yon are allowed to kill the birds which have bred upon your own property. Here

"You are as free as when God Srst made man, Ere the vile laws of servitude began, And wild in woods the noble savage ran."

The Partridge.

Before the morning's dawn you hear a noise in the forest, which sounds like " duraquaura" often repeated. This is the Partridge, a little smaller, and differing somewhat in colour from the Euglish partridge: it lives entirely in the forest, and probably the young brood very soon leave their parents, as you never fiush more than two birds in the same place, and in general only one.

Two species

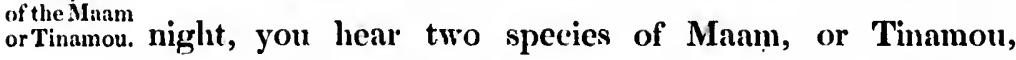

About the same hour, and sometimes even at midsend forth their long and plaintive whistle from the depth of the forest. The flesh of both is delicions. The largest is plumper, and almost equals in size the black cock of Northumberlind. The quail is said to be here, though rare.

The Hanna- The Hannaquoi, which some have compared to the quoi.

pheasant, though with little reason, is very common.

The Powise Here are also two species of the Powise or Hocco, and or Hocco.

two of the small wild turkies, called Maroudi; they feed on the ripe fruits of the forest, and are found in all 
directions in these extensive wilds. You will admire the horned Screamer as a stately and majestic bird: he is almost the size of the turkey cock; on his head is a long slender horn, and each wing is armed with a strong, sharp, triangular spur, an inch long.

Sometimes you will fall in with flocks of two or three Flocks of hundred Waracabas, or Trumpeters, called so from the orTrumpatsingular noise they produce. Their breast is adorned with beautiful changing bluc and purple feathers; their head and neck like velvet; their wings and back grey, and belly black. They run with great swiftness, and when domesticated, attend their master in his walks, with as much apparent affection as his dog. They have no spurs, but still, such is their high spirit and activity, that they browbent every dunghill fowl in the yard, and foree the Guinea birds, clogs, and turkies to own their superiority.

If, kind and gentle reader, thou slouldst ever visit these regions with an intention to examine their productions, perhaps the few ohservations contained in these wanderings may be of scrvice to thee: excuse their brevity: more could have been written, and each bird more particularly described, but it would have been pressing too hard upon thy time and patience.

Soon after arriving in these parts, thou wilt find that the species here enumerated are only as a handful from a well-stored granary. Nothing has been said of the 
Sxcond Eagles, the Falcons, the Hawks, and Shrikes; nothing JounNEy. of the different species of Vultures, the King of which is very handsome, and seems to be the only bird which claims regal honours from a surrounding tribe. It is a fact beyond all dispute, that when the seent of carrion has drawn together hundreds of the common Vultures, they all retire from the carenss as soon as the King of the Vultures makes his appearance. When his majesty has satisfied the eravings of his royal stomach with the choicest bits from the most stinking and corrupted parts, he generally retires to a neighbouring tree, and then the common Vultures return in crowds to gobble down his leavings. The Indians, as well as the Whites, have observed this; for when one of them, who has leamed a little English, sees the King, and wishes you to have a proper notion of the bird, he says, "There is the governor of the carrion crows."

Now, the Indians have never heard of a personage in Demerara higher than that of governor; and the colonists, through a common mistake, call the Vultures carrion crows. Hence the Indian, in order to express the doininion of this bird over the common Vultures, tells you he is governor of the carrion crows. The Spaniards have also observed it, for, through all the Spanish Main, he is called Rey de Zamuros, King of the Vultures. The many species of Owls, too, have not been noticed; and no mention made of the Columbine tribe. The prodigious 
variety of Water Fowl, on the sea-shore, has been but barely hinted at.

There, and on the borders and surface of the inland waters, in the marshes and creeks, besides the flamingos, searlet curlews, and spoonbills, already mentioned, will be found; greenish-brown curlews, sandpipers, rails, coots, gulls, pelicans, Jabirus, Nandapoas, crabiers, snipes, plovers, ducks, geese, cranes, and Anhingas; most of them in vast abundance; some fmonenting only the sea-const, others only the interior, according to their different natures; all worthy the attention of the naturalist, all worthy of a place in the cabinet of the curious.

Should thy comprehensive genius not confine itself to birds alone, grand is the appearance of otlier objects all around. Thou art in a land rich in botany and mineralogy, rich in zoology and entomology. Animation will glow in thy looks, and exercise will brace thy frame in vigour. The very time of thy absence from the tables of heterogeneous luxury will he profitable to thy stomach, perhaps already sorely . hed with Londo-Parisian sauces, and a new stock or health will bring thec an appetite to relish the wholesome food of the chase. Never-failing sleep will wait on thee at the time she comes to soothe the rest of animated nature; and, ere the sun's rays appear in the horizon, thou wilt spring from thy hammock fresh as the April lark. Be convinced also, that the dangers and difliculties which are generally

v 2 
Srcosi supposed to nccompany the traveller in his journey JOUHEYY. through distant regions, are not hulf so numerous or dreadful as they are commonly thought to be.

Dangers to hemded, not Drury-lane, nfter leaving the tuble sacred to the god of

imuginary. wine, is exposed to more certain ruin, sickness, and decay, than he who wanclers a whole year in the wilds of Demerara. But this will never be believed; because the disasters arising from dissipation are so common and frequent in civilized life, that man becomes quite habituated to them; and sees daily victims sink into the tomb long before their time, without ever once taking alarm at the causes which precipitated them headlong into it.

But the dangers which a traveller exposes himself to in foreign parts are novel, out of the way things to a man at home. The remotest apprehension of meeting a tremendous tiger, of being earried off by a flying dragon, or having his bones picked by a funished cannibal; oh, that makes him shudder. It sommds in his ears like the bursting of a bomb-shell. Thank heaven, he is safe by his own fireside.

Prudence and resolution ought to be the traveller's constant companions. The first will cause him to avoid a number of snares which he will find in the path as he journies on; and the second will always lend a hand to assist him, if he has unavoidably got entangled in them. 
The little distinctions which have been shown him at his own home, ought to be forgotten when he travels over the world at large ; for strangers know nothing of his former merits, and it is necessary thut they should witness them before they pay him the tribute which he was wont to receive within his own doors. Thus, to be kind and uffuble to those we meet, to mix in their anusements, to pay n compliment or two to their manners and customs, to respect their clders, to give a little to their distressed and needy, and to feel, as it were, at home munongst them, is the sure way to enuble you to pass merrily on, and to find other comforts as sweet and pulntable as those which you were aceustomed to partuke of amongst your friends and accuaintance in your own mutive land. We will now ascend in fancy on Icarinn wing, and take a view of Guiana in general. See an immense plain! betwixt two of the largest rivers in the world, level as a bowling-green, save at Cayemue, and covered with trees along the coast quite to the Atluntic wave, exeept whẹe the plantations make a little vacuney amongst the folinge.

'Though nearly in the centre of the torrid zone, the sun's rays are not so intolerable as might be imagined, on aceount of the perpetual verdure and refieshing north-east breeze. See what numbers of broad and rapid rivers intersect it in their journey to the ccean, and that not a stone or a pebble is to be found on their banks, or in any part of the 
country, till your eye catches the hills in the interior. How benutiful and inagnificent are the lakes in the lieart of the forests, and how charming the forests themselves, for miles ufter miles on each side of the rivers ! How extensive uppear the savannas or naturnl meadows, tecining with imumernble herds of cuttle, where the Portuguese and Spaniards ure settled, but desert ns Snara, where the English and Dutch clain dominion! How gradunlly the fuce of the country rises! See the sand-hills ull clothed in wood first emerging from the level, then hills a little higher, rugged with bold and craggy rocks, pecping out from amongst the most luxurinut timber. Then come plains, and dells, and far-extending vallies, arrayed in richest foliage; Ind beyond them, mountains piled on mountains, some bearing prodigious forests, others of bleak and barren aspect. Thus your eye wanders on, over seenes of varied loveliness and grundeur, till it rests on the stupendous pinnacles of the long-continued Cordiller'ns de los Andes, which rise in towering majesty, and command all America.

How fertile must the low-lands be, from the accumulation of fallen leaves and trees for centuries! How propitious the swanps and slimy beds of the rivers, heated by a downward sun, to the amazing growth of alligators, serpents, and inmmerable insects! How inviting the forests to the feathered tribes, where you see buds, blossoms, green and ripe fruit, full grown and fading leaves, all on 
the same tree! How secure the wild beasts may rove in cndless mazes! Perhnps those mountains too, which uppear so bleak and nuked, as if quite neglected, are, like Potosi, full of precious metals.

Let us now return the pinions we borrowed from Ienrus, Conclusion. and prepare to bid furewell to the wilds. The time allotted to these wanderings is drawing fast to a close. Every day for the last six months has been employed in paying close attention to Natural History in the forests of Demerara. Above two hundred specimens of the finest birds have been collected, and $\mathrm{n}$ pretty just knowledge formed of their haunts and cconomy. From the time of leaving England, in March, 1816, to the present day, nothing has intervened to arrest a fine flow of health, saving a cuartau ague, which did not tarry, but fled as suddenly as it appeared.

And now I take leave of thee, kind and gentle reader. The new mode of preserving birds, heretofore promised thee, shall not be forgotten. The plan is already formed in imagination, and can be penned down during the passage across the Atlantic. If the few remarks in these wanderings shall have any weight in inciting thee to sally forth, and explore the vast and well-stored regions of Demerara, I have gained my end. Adieu.

CHARLES WATFRTON.

April 6, 1817. 


\section{THIRD JOURNEY.}

"Desertosque videre locos, littusque relictum."

Cimno Gextse reader, after stuying a few months in England, I Jovkxry. strayed across the $A l p s$ and the Apemines, and returned home, but could not tarry. Guimu still whispered in my ear, and scemed to invite me once more to wander through her distant forests.

Shouldst thou have a leisure hour to read what follows, I pray the pardon the frequent use of that mweleome monosyllnble I. It conld not well be avoided, as will be seen in the sepuel. In February, 1820, I sailed from the Clyde, on bond the Glenbervie, a fine WestJndiaman. She was driven to the north-west of Ireland, and had to contend with a foul and wintry wind for above a fortnight. At last it changed, and we had a pleasant passage across the Atlantic.

Yellow fever at Demeriara.

Sad and mouruful was the story we heard on entering the river Demerara. The yellow fever had swept off numbers of the old inhabitants, and the mortal remains 
of many a new comer, were daily passing down the Tump streets, in slow nud inute pmoxeswion to their last restingplace.

After stnying " fow enys in the town, I went up the Residence Demernarn to the former lubitution of my worthy friend, ereek. Mr. Echmonstone, in Milsiri creck.

The house hud been mbundoned for some years. On arriving at the hill, the romembrunce of seenes long past and gone, naturully broke in upon the mind. All was chunged; the house wis lin mins, und gradually sinking under the influenes of the sun ind anin; the roof had nearly fullen in; Ind the room, where once governors

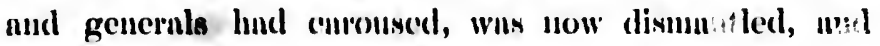
tenanted by the vampire. You would have suid,

\footnotetext{
" "Jis now thu rumpire's blenk mbode, "lis now llae npurfunent of the tomel: "Tis liero the puinful cloggoe fects,

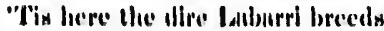
Conserul'al In rulum, mons, mul weeds."
}

On the outside of the humse, nature had nearly reassumed her ancient right: " few stronggling fruit-trees were still discernible muid llac vuriod hue of the near appronching forest ; they scemed like strmugers lost, and bewildered, mud mupitichl, in a fi, an land, destined to linger a little longer, mul the'n sink town for ever.

I hired some negrow from $n$ woodentter in another conserted creek to repair the roof ; Imol then the louse, or at least inther's 
Tulro Joun:ey.

what remained of it, became head-quarters for natural history. The frogs, and here and there a snake, received that attention which the weak in this world generally experience fiom the strong, and which the law commonly denominates an ejectment. But here, neither the frogs nor serpents were ill-treated; they sallied forth, without buffet or rebuke, to choose their place of residence. The world was all before them ; the owls went away of their own accord, preferring to retire to a hollow tree rather than to associate with their new landlord. The bats and vampires staid with me, and went in and out as usual.

It was upon this hill in former days that I first tried to teach John, the black slave of my friend Mr. Edmonstone, the proper way to do birds. But John had poor abilities, and it required much time and patience to drive any thing into him. Some years after this his master took lim to Scotland, where, becoming free, John left him, and got employed in the Glasgow, and then the Edinburgh museum. Mr. Robert Edinonstone, nephew to the above gentleman, had a fine mulatto capable of learning any thing. He requested me te teach him the art. I did so. He was docile and active, and was with me all the time in the forest; I left him there to keep up this new art of preserving birds, and to comm!nicate it to others. Here then I fixed my head-quarters, in the ruins of this once gay and hospitable house. Close by, in a little 
hut, whieh, in times long past, had served for a store to keep provisions in, there lived a coloured man and his wife, by name Backer. 'Many a kind turn they did to me; and I was more than once of service to them and their children, by bringing to their relief, in time of sickness, what little knowledge if had acquired of medicine.

I would here, gentle reader, wish to draw thy atten- Raiment tion, for a few minutes, to physic, raiment, and diet. Shouldst thou ever wander through these remote and dreary wilds, forget not to earry with thee, bark, laudanum, calomel, and jalap, and the laneet. There are in druggist shops inere, nor sons of Galen to apply to in time of need. I never go encumbered with many clothes. A thin flannel waistcont under a eleck shirt, a pair of trowsers, and a hat, were all my wardrobe : shoes and stockings I seldom had on. In dry weather they would have irritated the feet, and retarded me in the chase of wild beasts; and in the rainy season they would have kept me in a perpetual stnte of dimp and moisture. I eat moderately, and never drink wine, spirits, or fermented liquors in any climate. 'This abstemiousness has ever proved a faithtul friend; it carried me triumphant through the epidemia at Malaga, where denth made such havoc about the beginning of the present eentury; and it has since befriended me in many a fit of sickness, brouglit on by exposure to the noon-day sun, to 
Tmad the ders of night, to the pelting shower, and unwholeJovRNEY. some food.

Perhaps it will be as well, here, to mention a fever which came on, and the treatment of it ; it may possibly be of use to thee, shouldst thou turn wanderer in the tropies : a word or two also of a wound $I$ got in the forest, and then we will say no more of the little accidents which sometimes occur, and attend solely to natural history. We shall have an opportunity of seeing the wild animals in their native haunts, undisturbed and unbroken in upon by man. We shall have time and leisure to look more closely at them, and probably rectify some errors which, for want of proper information, or a ncar observance, have crept into their several histories.

Severe attick of

It was in the month of June, when the sun was withis. fever. a few days of Caneer, that I had a severe attack of fever. There had been a deluge of rain, accompanied with tremendous thunder and lightning, and very little sum. Nothing could exceed the dampness of the atmosphere. For two or three days I had been in a kind of twilight state of health, neither ill nor what you may call well; I yawned and felt weary without exercise, and my sleep was merely slmmber. This was the time to have taken medicine; but I neglected to do so, though I had just been reading, “ $O$ navis referent in mare te novi fluctus, O quid agis ? fortiter oceupa portum." I awoke at midnight ; a cruel head-ach, thirst, and pain in the small of 
the back, informed me what the case was. Had Chiron himself been present, he could not have told me more Turo distinetly that I was going to have a tight brush of it, and that $I$ ought to meet it with becoming fortitude. I dozed, and woke, and startled, and then dozed again, and suddenly awoke, thinking I was falling down a precipice.

The return of the bats to their diumal retreat, which was in the thateh above my hammock, informed me that the sun was now fast approaching to the eastern horizon. $I$ arose, in languor and in pain, the pulse at one hundred and twenty. I took ten grains of calomel and a scruple of jalap, and cirank during the day large dranghts of tea, weak and warm. The physic did its duty; but there was no remission of fever or head-ach, though the pain in the back was less acute. I was saved the trouble of kecping the room cool, as the wind beat in at every quarter.

At five in the evening the pulse had risen to one hundred and thirty, and the head-ach almost insupportable, especially on looking to the right or left. I now opened a vein, and made a large orifice, to allow the blood to rush out rapidly ; I closed it after losing sixteen omees. I then stecped my feet in warm waier, and got into the hammock. After bleeding, the pulse fell to ninety, and the head was much relieved; but during the night, which was very restless, the pulse rose again to 
THIRo JockNeY. one hundred and twenty, and at tincs the head-ach was distressing. I aclieved the head-ach from time to time, by applying cold water to the temples, and loolding a wet handkerehief there. The next morning the fever ran very high, and I took five more grains of calomel and ten of jalap, determined, whatever might be the case, this should be the lave dose of enlomel. About two o'clock in the after wolis the fever remitted, and a copions perspiration eame on; there was no more lead-ach, nor thirst, nor pain in the back, and the following night was comparatively a good one. The next morning I swallowed a large dose of eastor oil: it was genuine, for Louisa Backer had made it from the seeds of the trees which grew ncar the door. I was now entirely free from all symptoms of fever, or apprehensions of a return; and the moming after I began to take bark, and continued it for a fortuight. This put all to rights.

Meets with an necident.

The story of the wound 1 got in the forest, and the mole of cure, are very short.-I had pursued a redheaded woodpecker for above a mile in the fortat, without being able to get a shot at it. Thinking more of the woolyecker, as I ran along, than of the way before me, I trod upon a little hardwood stump which was just about an inch or so above the ground; it entered the hollow part of my root, making a deep and a ecrated wound there. It had brought me to the ground, and there I lay till a transitory fit of sickness went off. 
I allowed it to bleed freely, and on reaching headquarters, washed it well and probed it, to feel if any foreign body was left within it. Being satisfied that there was none, I brought the edges of the wound together, and then put a piece of lint on it, and over that a very large poultice, which was changed morning, noon, and night. Luckily, Backer had a cow or two upon the hill; now, as heat and moisture are the two principal virtues of a poultice, nothing eould produce those two qualities better than fresh cow-dung boiled: had there been no cows there, I could have made out with boiled grass and leaves. I now took eutirely to the hammock, placing the foot higher than the linee; this prevented it from throbbing, and was, indeed, the only position in which I could be at ease. When the inflammation was completely subdued, I applied a wet eloth to the wound, and every now and then steeped the foot in cold water during the day, and at night again applied a poultice. The wound was now healing fast, and in three weeks from the time of the accident, nothing but a sear remained; so that $I$ agnin sallied forth sound and joyful, and said to myself-

$$
\begin{aligned}
& \text { "I, que te pedes rapiunt et aure } \\
& \text { Dum favet sol, et locus, i secundo } \\
& \text { Omine, et conto latebras, ut olim, } \\
& \text { Rumpe ferarum." }
\end{aligned}
$$

Now, this contus was n tough light pole, eight feet long, on the end of which was fixed an old bayonet. I never 
Turı D JovRxFy.

Last conversation with Sir

Joseph

Banks.

went into the canoe without it; it was of great use in starting the beasts and suakes ont of the hollow trees, and, in case of need, was an excellent defence.

In 1819, I had the last conversation with Sir Joseph Banks. I saw with socrow that death was going to pob us of him. We talked much of the present mode adopted by all muscums in stufling quadrupeds, and conslemned it as being very imperfect ; still we could not fincl out a better way; and at last concluded, that the lips and nose ought to be cut off, and replaced with wax; it being impossible to make those parts appen like life, as they shrink to nothing, and rencler the stuffer specimens in the different muscums horrible to look at. The defects in the legs and feet would not be quite so glaring, being coverel witl hair.

Stufing I had paid great attention to this subject for above birds und
quadrupeds. fourteen years; still it would not do : however, one night, while I was lying in the hammock, and harping on the string on which hung all my solicitude, I hit upon the proper mode by inference; it appeared clear to me that it was the only true way of going to work, mul ere I closed my eyes in sleep, I was able to prove to mysel: that there could not be any other way that would answer. I tried it the next day, and suceeded aceording to expectation.

By means of this process, which is very simple, we can now give every feature back again to the animal's face, 
after it has been skimmed; and when necessary, stamp Tma grief, or pain, or pleasure, or rage, or mildness upon it. JothNEY. But more of this hereafter.

Let us now turn our attention to the Sloth, whose The Sluth. native haunts have hitherto been so little known, and probably little looked into. Those who have written on this singular animal have remarked that he is in a perpetual state of pain, that he is proverbially slow in his movements, that he is a prisoner in space, and that as soon is he has consumed all the leaves of the tree upon which he had mounted, he rolls himself up in the form of a ball, and then falls to the ground. This is not the case.

If the naturalists who have written the history of the Sloth had gone into the wilds, in order to examine his haunts and economy, they would not have drawn the foregoing conclusions; they would have leamed, that though all other quadrupeds may be described while resting upon the ground, the Sloth is an exception to this rule, and that his history must be written while he is in the tree.

This singular animal is destined by nature to be produeed, to live and to die in the trees; and to do justice to him, naturalists must examine him in this his upper element. He is a searce and solitary animal, and being good food, he is never nllowed to escape. He inliabits Lives in remote and gloomy forests, where snakes take up their glomy abode, and where eruelly stinging ants and seorpions, 
Tnind and swamps, and innumerable thorny shrubs and bushes, JotRNeY. obstruct the steps of civilized mun. Were you to draw your own conclusions firom the descriptions which have been given of the Sloth, you would probably suspect, that no naturalist has actually gone into the wilds with the fixed deternination to find him out and examine his haurts, and sce whether nature has committed any blunder in the formation of this extraordinary creature, which appears to us so forlorn and miscrable, so ill put together, and so totally unfit to enjoy, the blessings which have been so bountifully given to the rest of animated nature; for, as it has formerly been remarked, he has no soles to his feet, and he is evidently ill at ense when he tries to move on the ground. and it is then that he looks up in your face with a countenance that says, " Have pity on me, for I am in pain and sorrow."

It mostly happens that Indians and Negroes are the people who eatch the Sloth, and bring it to the white man: hence it may be conjectured that the crroneous accounts we have hitherto had of the Sloth, have not been penned down with the slightest intention to mislead the reacler, or give him an exaggerated history, bur that these errors have naturally arisen by examining the Sloth in those places where nature never intended that he should be exhibited.

However, we are now in his own domain. Man but little frequents these thick and noble forests, which 
extend fur and wide on every side of us. This, then, is the proper place to go in quest of the Sloth. We will first mke a neur view of him. By obtuining a knowledge of his anntomy, we shall be enabled to account for his Anatomy of movements hereafter, when we see him in his proper lanuts. His fore-legs, or, more correctly speaking, his arms, are apparently much too long, while his hind-leg; are very short, and look ns if they could be bent almost to the shape of a corkserew. Both the fore and hind legs, by their form, and by the mamer in which they are joined to the body, mẹ quite ineapacitated from neting in a perpendicular direction, or in supporting it on the eurth, as the bodies of ofher (quadrupeds me supported, by their legs. Henee, when you place him on the floor, his beliy touches the ground. Now, granted, that he supported himself on his legs like other animals, nerertheless he would be in pain, for he has no soles to his fect, and his claws are very sharp and long, and curved; so that, were his body supported by his fect, it would be by their extremities, just ats your body would be were you to throw yourself on all fours, and try to support it on the ends of your toes and fingers-a trying position. Were the floor of glass, or of a polished surfuce, the Sloth would actually be quite stationary; but as the ground is generully rough, with little protuberances upon it, such'as stones, or roots of grass, \&c., this just suits the Sloth, and he moves his fore-legs in 
TIIIRD JCUANEY.

all directions, in order to find something to lay hold of ; and when he has succeded, he pulls himself forward, and is thus enabled to travel onwurds, but at the same time in so turdy and awkward a manner, as to aequire him the name of Sloth.

Indeed his looks and his gestures evidently betray his uncomfortnble situation; and as a sigh cvery now and then escupes him, we may be entitled to conclude that lie is actually in pain.

Some years ngo I kept a Sloth in my room for several months. I often took him out of the house, and pluced him upon the ground, in order to have un opportunity of observing his motions. If the ground were rough, he would pull himself forwards, by menus of his fore-legs, at a pretty good pace; and he invurinbly shaped his course towards the nearest trec. But if I put lim upon a smooth and well-trodden part of the rond, he appenred to be in trouble and distress: his favourite abode wns the back of a chair; and after getting all his legs in a line upon the topmost part of it, he would hang there for hours together, and often, with a low and inward ery, would seem to invite me to take notice of him.

The Sloth, in its wild state, spends its whole life in the trees, and never leaves them but through force, or by accident. An all-ruling Providence has ordered man to tread on the surface of the earth, the eagle to soar in the expanse of the skies, and the monkey and squirrel 
to inhabit the trees : still these mny ehange their relative situntions without feeling much inconvenience : but the Sloth is doomed to spend his whole life in the trees; and, what is more extrnordinary, not upon the branches, like the squir'rel and the monkey, but under them. He moves suspended from the branch, he rests suspended from it, und he sleeps suspended from it. To enable him to do this, he must have a very different formation from that of any other known quadruped.

Hence, his scemingly bungled conformation is at once accounted for ; and in lien of the Sloth leading a painful life, and entuiling a melancholy and miserable existence on its progeny, it is but fuir to surmise that it just enjoys life as mueh as any other animal, and that its extraordinary formation and singular habits are but further proofs to engage us to admire the wonderful works of Omnipotence.

It must be observed, that the Sloth does not hang head-downwards like the vampire. When asleep, he supports himself from a brauch parallel to the earth. He first seizes the branch with one arm, and then with the other ; and after that, brings up both his legs, one by one, to the same branch; so that all four are in a line: he seems perfectly at rest in this position. Now, had lie a tail, he would be at a loss to kyow what to do with it in this position: were he to draw it up within his legs, it would interfere with them; and were he to let 
Т'แии JOC'RNEY it hang down, it would becone the sport of the ninds. Thus his cleficiency of tuil is a benefit to him ; it is unerely an apology for $"$ tail, scureely exceeding nn inch and $n$ half in lengtli.

I observed, when he was climbing, he never used his urms both together, but first one and then the other, and so on alternately. There is " singularity in his hair, diffierent from that of all oflee mimals, and, I believe, hitherto unnoticed by naturulists ; his hair is thick and coarse at the extremity, and gradually tupers to the root, where it becomes fine as the finest spider's web. His fur hus so much the lue of the moss which grows on the branches of the trees, that it is very difficult to muke him out when he is at rest.

The male of the three-toed sloth has a longitudinal bar of very fine black hair on his back, rather lower than the slioulder-blades; on ench side of this bluck bar there is a spnec of yellow hair, equally fine; it has the appearance of being pressed into the body, and looks exactly us if it had been singed. If we exumine the anntomy of his fore-legs, we slanll immediately perceive by their firm and muscular texture, how very enjable they are of supporting the pendent weight of his body, botl in climbing and at rest; and, instead of pronouncing them a bungled composition, as a celebrated naturalist has done, we shall consider them as remarkably well calculated to perform their extraordinary functions. 
As the Sloth is IIII inlunbitunt of forests within the tropies, where the trees toneh ench other in the grentest TuIRn profitsion, there secens to be no beason why he shosuld confine himself to one tree uine for food, and entirely strip it of its lenves. Buring the many yems 1 have ranged the forests, I linse nevere seen a tree in such a state of mudity: indered, I would hazaurd a conjecture, that, by the time the minnul hud finished the last of the old leaves, there would be 1 new aresp on the pout of the tree he hud stripped first, rendy for him to begin aguin, so apuick is the procesens of regetation in these countries.

The:e is a saying mnongst the Indinns, that when the wind Llows, the Sloth bepins to trinvel. In ealm weather he remnins tran(juil, probubly)y not liking to cling to the brittle extremity of the Irmuches, lest they should break with him in pussing from one tree to nnother; but as soon as the wind risen, the brenches of the neighbouring trees become interwoven, und then the Sloth scizes hold of them, and pursues his journey in safety. There is seldom an entire dny of cenlm in these forests. The tradewind generally setw in ulout ten o'clock in the morning, and thus the Sloth mny net off after brenkfast, and get a considerable way before dinner. He travels at a good round pace; and were you to see him pass from tree to tree, as I have done, you would never think of calling him a Sloth. 
T:IRD Jocknex.

Thus, it would appear that the different histories we have of this quadruped are erroneous on two accounts : first, that the writers of them, deterred by difficulties and local amoymees, have not paid sufficient attention to him in his native haunts; and secondly, they have deseribed him in a situation in which he was never intended by nature to cut a figure; 1 mean on the gromnd. The Sloth is as much at a loss to proceed on his journey upon a smooth and level floor as a man would be who had to walk a mile in stilts upon a line of feather beds.

The two-

One day, as we were crossing the Essecpuibo, I saw a large two-toed Sloth on the ground upon the bank; how he had got there nobody could tell: the Inclian said he had never surprised a Slot': in such a situation before : he would hardly have eome there to drink, for both above and below the place, the branches of the trees touched the water, and aftorded him an ensy and safe aceess to it. Be this as it ming, though the trees were not above twenty yardis from him, he could not make his way throngh the sand time enongh to escape before we landed. As soon as we got up to him he threw himself upon his back, and defended himself in gal'ant style with his fore-legs. "Come, poor fellow," snid I to him, " if thon hast got into a hobble to-day, thon shnlt not suffer for it: I'll take no advantage of thee in misfortune; the forest is large enough both for thee and me 
to rove in : go thy ways up above, and enjoy thyself in these endless wilds; it is more than probable thou wilt never have another interview with man. So fare thee well." On saying this, I took up a long stick which was lying there, held it for him to hook on, and then conveyed him to a high and stately Mora. Ho ascended with wonderful rapidity, and in about a minute le was alnost at the top of the tree. He now went off in a side clirection, and caught hold of the branch of a neighbouring tree; he then proceeded towards the heart of the forest. I stood looking on, lost in amazement at his singular mode of progress. I followed him with my eye till the intervening branches elosed in betwixt us; and then I lost sight for ever of the two-toed Sloth. I was going to atd, that I never saw a Sloth take to his heels in such earnest; but the expression will not do, for the sloth has no licels.

'Thut which naturalists have advaneed of his being so tenacious of life, is perfectly true. I saw the heart of one beat for half an hour alter it was taken out of the body. The wourali poison seems to be the only thing that will kill it quickly. On reference to a lormer part of these wanderings, it will be seen that a poisoned arrow killed the Sloth in ubout ten minutes.

So much for this harmless, moftending amimal. He holds a conspicuous place in the eatalogue of the animals of the new world. Though naturalists have made no 
mention of what follows, still it is not less true on that JOtRNEY.

aceount. The Sloth is the only quadruped known, which spends its whole life from the branch of a tree, suspended by his feet. I have paid uncommon attention to him in his native haunts. The monkey and squirrel will seize a brancl: witis their fore feet, and pull themselves up, and rest or run upon it: but the Sloth, after scizing it, still remains suspended, and suspended moves along under the branch, till he can lay hold of another. Whenever I have seen him in his native woods, whether at rest, or asleep, or on his travels,. I have always observed that he was suspended from the branch of a tree. When his form and anatomy are attentively considered, it will appen' eviclent that the Sloth caunot be at ease in any situation, where his body is higher, or above his feet. We will now take our leave of him.

Ants. In the fir-extending wilds of Guiana, the traveller will be astonished at the immense quantity of Ants which he pereeives on the ground and in the trees. They have nests in the branches, four or five times as large as that of the rook; and they have a covered way from them to the ground. In this eovered way thousands are perpetually passing and repassing ; and if you destroy part of it, they turn to, and immediately repair it.

Other species of Ants again have no covered way ; but travel, exposed to view, upon the surfaee of the earth. You will sometimes see a string of these Ants a mile long, 
each carrying in its mouth to its nest a green leaf, the size of a sixpence. It is wonderful to observe the order in which they move, and with what pains and libour they surmount the obstructions of the path.

The Ants have their enemies, as well as the rest of Three animated nature. Amongst the foremost of these stand Ant-bears. the three species of Ant-bears. The smallest is not much larger than a rat; the next is nearly the size of a fox; and the third a stout and powerful animal, mensuring above six feet from the snout to the end of the tail. He is the most inoffensive of all animals, and never injures the property of man. He is chicfly found in the immost recesses of the forest, and seems partial to the low and swampy parts near creeks, where the Troely tree grows. There he goes up and down in quest of Ants, of which there is never the least seareity; so that he soon obtains a sufficient supply of food, with very little trouble. He cannot travel fast; man is superior to him in speed. Without swiftness to enable him to escape firem his enemies, without teeth, the possession of which woud assist him in self-defence, and without the power of burrowing in the ground, by which he might conecal himself from his pursuers, he still is capable of ranging through these wilds in perfeet safety; nor dons lic fear the futal pressure of the scrpent's fold, or the teeth of the fimished Jagnur. iNature has formed his fore legs wonderfully thick, and strong, and muscular, and armed his fect with three 
Tund JoYrNEY. tremendons sharp and crooked claws. Whenever he seizes an animal with these formidable weapons, he hugs it close to his body, and keeps it there till it dies through pressure, or through want of food. Nor does the Antbear, in the mean time, suffer much from loss of aliment, as it is a well known fact, that he can go longer without food than, perhaps, any other animal, except the land tortoise. His skin is of a texture that perfeetly resists the bite of a $\log$; his hinder parts are protected by thick and shaggy hair, while his immense tail is large enough to cover his whole body.

The Indians lave a great dread of coming in contact with the Ant-bear; and siter disalbling him in the chase. never think of approaching him till he be quite dead. It is perhaps on account of this cantion, that muturalists have never yet given to the world a true and correct drawing of this singnlar animal, or described the peuliar position of his fore feet when lie walks or stands. If, in taking a drawing from a dead Ant-loear, you judge of the position in which he stands from that of all other terrestrial animals, the sloth exeepted, you will be in error. Examine ouly a figure of this animal, in books of natural history, or inspeet a stuffed specimen in the best museums, and you will see that the fore claws are just in the same forward attitude, as those of a dog, or a common bear, when he walks or stands. But this is a distorted and unnatural position; and in life, would be a painful and 
intolerable attitude for the Ant-bear. The length and curve of his claws camnot admit of such a position. When he walks or stands, his feet have somewhat the appearance of a club-hand. He goes entirely on the outer side of his fore feet, which are quite bent inwards ; the claws collected into a point, and going under the foot. In this position he is quite at ease; while his long claws are disposed of in a manner to render them harmless to him, and are prevented from becoming dull and worn, like those of the dog, which would incvitably be the case, did their points come in actual contact with the ground; for his elaw's have not that retractile power which is given to animals of the feline species, by which they are enabled to preserve the sharpmess of their claws on the most flinty path. A slight inspection of the fore feet of the Antbear, will immediately convince yon of the mistake artists and uaturalists have fallen into, by putting his fore feet in the same position as that of other quadrupeds; for you will perecive that the whole outer side of his foot is not only deprived of hair, but is hard and callous; proof positive of its being in perpetual contact with the ground. Now, on the contrary, the inner side of the bottom of his foot is soft and rather hairy.

There is another singularity in the anatomy of the peeuliarity Ant-bear, I believe, as yet unnoticed in the page of natural in the anahistory. He has two very large glands situated below Ant-bear. the root of the tongue. From these is emitted a glutinous 
Truno liquid, with which his long tongue is lubricated when he Jouney. puts it into the ants' nests. These glands are of the same substance as those found in the lower jaw of the woodpecker. The secretion from them, when wet, is very clammy and adhesive, but on being dried it loses these qualities, and you can pulverize it betwixt your finger and thumb; so that, in dissection, if any of it has got upon the fiur of the animal, or the feathers of the bird, allow it to dry there, and then it may be removed without leaving the least stain behind.

The Ant-bear is a pacific animal. He is never the first to begin the attack. His motto may be, "Noli me tangere." As his habits and his haunts differ materially from those of every other amimal in the forest, their interests never clash, and thus he might live to a good old age, and die at last in peace, were it not that his flesh is good food. On this accomit, the Indian wages perpetual war against him, and as he cannot eseape by thight, he fulls an easy prey to the poisoned arrow, shot from the Indian's bow at a distance. If ever he be closely attacked by dogs, he immediately throws himself on his back, and if he be fortumate enough to catch hold of his enemy with his tromenclous claws, the invader is sure to pay for his rashness with the loss of life.

The Vin- We will now rake a view of the Vampire. As there pire. was a fiee entrances and exit to the Vampire, in the loft where 1 slept, I hiad many a finc opportunity of paying 
attention to this nocturnal surgcon. He does not always live on blood. When the moon shone bright, and the fruit of the Bamana-tree was ripe, I eould see him approach and ent it. He would also bring into the loft, from the forest, a green round fruit, something like the wild Guava, and about the size of a nutmeg. There was something also, in the blossom of the Sawarri nut-tree, which was grateful to him; for on coming up Warotilla crcek, in a moonlight night, I saw several Vampires fluttering round the top of the Sawarri tree, and every now and then the blossoms, which they had broken off, fell into the water. 'They certainly did not drop off naturally, for on examining several of them, they appeared quite fresh and blooning. So I coneluded the Vampires pulled them from the tree, either to get at the incipient fruit, or to cutch the inseets which often tuke up their aibode in flowers.

The Vampire, in general, measures about twenty-six inches from wing to wing extended, though I once killed one which measured thirty-two inches. He fiepuents old abandoned houses and hollow trees; and sometimes a cluster of them may be seen in the forest hanging head downwards from the branch of a tree.

Goldsmith seems to have been aware that the Vampire hangs in elusters, for in the " Deserted Village," speaking of America, he says,- 

But silent bats in drowsy clusters eling."

The Vampire has a curious membrane, which rises from the nose, and gives it a very singular appearance. It has been remarked before, that there are two speeies of Vampire in Guiana, a larger and a smaller. The larger sueks men and other unimals; the smaller seems to confinc himself chictly to birds. I learnt from a gentleman, high up in the river Demerara, thut he was completely unsuceessful with his fowls, on account of the small Vampire. He showed me some that had been sueked the night before, and they were searcely able to walk.

Anecdote. Some years ago I went to the river Pummaron with a Scoteh gentleman, by nime Tarbet. We lung our hammocks in the thatehed loft of a planter's house. Next morning I heard this gentleman muttering in his hammock, and now and then letting fill an imprecation or two, just about the time he ought to have been saying his morning prayers. “"What is the matter, Sir," said I, softly; "is any thing amiss ?" " What's the mutter ?" answered he, surlily ; " why, the Vampires have been sucking me to death." As soon as there was light enough, I went to his hammock, and saw it much stained with blood. "There," said he, thrusting his foot ont of the hammock, " see how these infernal imps have been drawing my life's blood." On examining his 
foot, I found the Vampire had tapped his grent toe : there was a wound somewhat less than that made by a leech; the blood wns still oosing from it ; I conjectured he might have lost from ten to twelve ounces of blood. Whilst examining it, I think I put him into a worse humour by remarking, that in Europeun surgeon would not have been so generous as to huve blooded him without muking a churge. He looked up in my face, but did not say a word : I saw he was of opinion that I had better huve spared this piece of ill-timed levity.

It was not the last punishment of this good gentleman Species of in the river Pammaron. The next night he was doomed Ant. to undergo a kind of ordeal unknown in Europe. 'There is a species of large red Ant in Guimu, sometimes called Ranger, sometimes Coushie. These Ants march in millions throngh the comntry, in compact order, like a regiment of soldiers; they eat up every insect in their march; and if a house obstruct their route, they do not turn out of the way, but go quite through it. Though they sting eruelly when molested, the planter is not sorry to see them in his house; for it is but a passing visit, mud they destroy every kind of inseet vermin that had taken shelter under his roof.

Now, in the British plantations of Guima, as well as in Europe, there is always a little temple dedicated to the goddess Cloacinn. Our dimner had chictly consisted of crabs, dressed in rich and different ways. Pammaron is 
Tunn JOVRNEY.

funous for crabs, and strangers who go thither, consider the'm the greatest luxury. 'The Scotch gentlemun mnde a very eapital dimer on crabs; but this change of diet was productive of umpleasant circumstances: ho awoke in the night in thut state in which Virgil deseribes Cieleno to have been, viz. "fiedissima ventris proluvies." Up he got, to verify the remurk,

"Serius aut eitius, sedem properamus ad unan."

Now, unluckily for himself, and the nocturnal trauquillity of the planter's house, just at that unfortunate hour, the Coushie ants were passing across the seat of Cloacina's temple; he had never dreamed of this ; and so, turning his face to the door, he placed himself in the usual situation which the votaries of the goddess generally take. Had a lighted match dropped upon a pound of gunpowder, as he afterwards remarked, it could not haye caused a greater recoil. Up he jumped, and forced his way out, rouring for help and for a light, for he was worried alive by ten thousand devils. The fact is, lie had sat down upon an intervening body of Coushic auts. Many of those which escaped being erushed to death, turned again; and, in revenge, stung the unintentional intruder most severely. The watchman had fallen asleep, and it was some time before a light could be procured, the fire having gone out; in the mean time, the poor gentleman was suffering an indescribable martyrdom, and would have found himsolf 
more at home in the Augean stuble thn in the planter's house.

I had often wished to have been once sucked by the Vampire, in order that I might have it in my power to say it had really happened to me. There can be no pain in the operation, for the patient is always asleep when theVampire is sucking him; and ns for the loss of a few ounces of blood, that would be a trifle in the long run. Muny a night have / lept with my foot out of the hammock to tempt this w if surgeon, expecting that he would be there; but it was in , th vain; the Vampire never sucked me, and I conld never account for his not doing so, for we were inhabitants of the same loft for monthstogether.

The Armadillo is very common in these forests; he The Armaburrows in the sand-hills like a rabbit. As it often takes a considerable time to dig him out of his hole, it would be a long and laborious business to attnck each hole inliscriminately witlout knowing whether the animal wers there or not. To prevent disappointment, the Indians carefully examine the mouth of the hole, and put a short stick down it. Now if, on introducing the stick, a number of Mosquitos come out, the Indiuns know to a certainty that the Armadillo is in it : wherever there are no Mosquitos in the hole, there is no Armadillo. The Indian having satisfied himself that the Armadillo is there, by the Mosquitos which come out, he immediately cuts a long and slender stick, and introduces it into the

$$
2 \text { \& } 2
$$




$$
\text { - }
$$




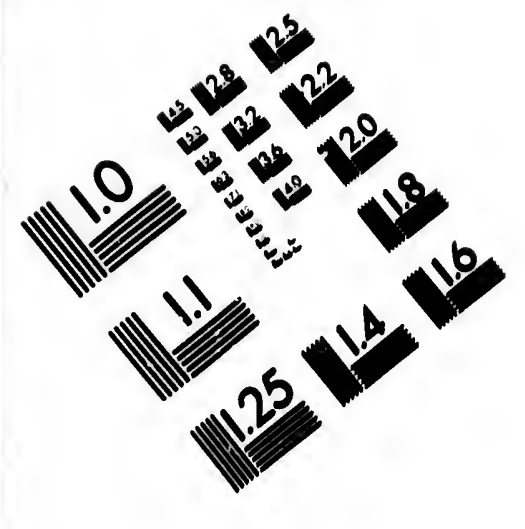

IMAGE EVALUATION
TEST TARGET (MT-3)
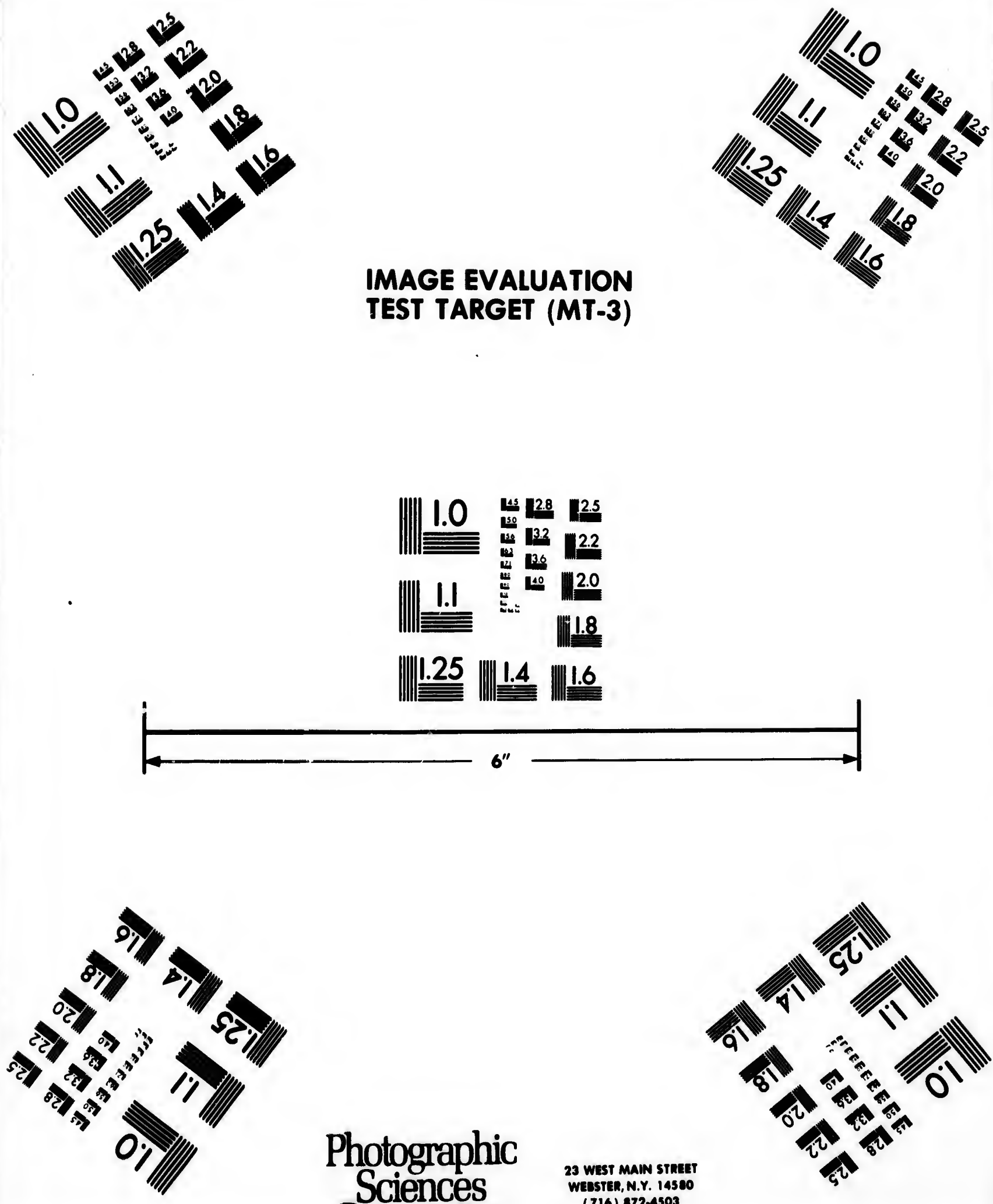

Photographic Sciences

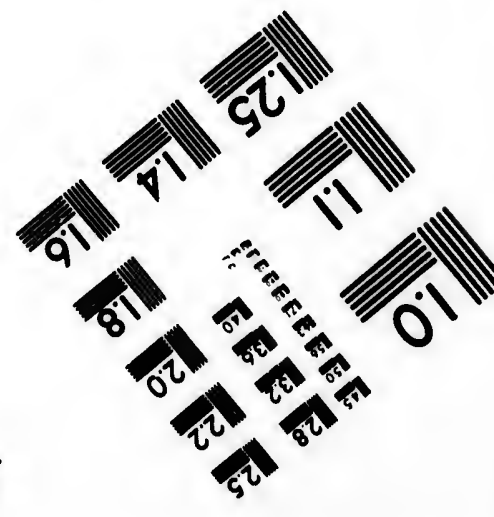
Corporation 
$<0$

48 
hole : he carefully observes the line the stick takes, and then sinks a pit in the sand to catch the end of it : this done, he puts it farther into the hole, and digs another pit, and so on, till at last he comes up with the Armadillo, which had been making itself a passage in the sand till it had exhausted all its strength through pure exertion. I have been sometimes three quarters of a day in digging out one Armadillo, and obliged to sink half a dozen pits, seven feet deep, before $I$ got up to it. The Indians and negroes are very fond of the flesh, but $I$ considered it strong and rank.

On laying hold of the Armadillo you must be cautious not to come in contact with his feet : they are armed with sharp claws, and with them he will inflict a severe wound in self-defence : when not molested, he is very harmless and innocent; he would put you in mind of the hare in Gay's fables,-

"Whose care was never to offend, And every creature was her friend."

The Armadillo swims well in time of need, but does not go into the water by choice. He is very seldom seen abroad during the day; and when surprised, he is sure to be near the mouth of his hole. Every part of the Armadillo is well protected by his shell, except his ears. In life, this shell is very limber, so that the animal is enabled to go at full stretch, or roll himself up into a ball, as occasion may require. 
On inspecting the arrangement of the shell, it puts you very much in mind of a coat of armour; indeed it is a THIRD natural coat of armour to the Armadillo, and being composed both of scale and bone, it affords ample security, and has a pleasing effect.

Often, when roving in the wilds, I would fall in with The land the land Tortoise; he too adds another to the list of unoffending animals; he subsists on the fallen fruits of the forest. When an enemy approaches he never thinks of moving, but quietly draws himself under his shell, and there awaits his doom in patience: he only seems to have two enemies who can do lim any damage ; one of these is the Bon Constrictor: this snake swallows the Tortoise alive, shell and all. But a Boa large enough to do this is very scarce, and thus there is not much to apprehend from that quarter; the other enemy is man, who takes up the Tortoise and carries him away. Man also is scarce in these never-ending wilds, and the little depredations he may commit upon the Tortoise will be nothing, or a mere trifle. The tiger's teeth cannot penetrate its shell, nor can a stroke of his paws do it any damage. It is of so compact and strong a nature that there is a common saying, a London waggon might roll over it and not break it.

Ere we proceed, let us take a retrospective view of the five animals just enumerated; they are all quadrupeds, and have some very particular mark, or mode of existence, 
Turs different from all other nuimals. The Sloth has four feet, Jounser. but never can use them, to support his body on the earth; they wint soles, which are a marked fenture in the feet of other unimuls. The Ant-bear has not a tooth in his hend, still he roves fenless on, in the same forests with the Jucuni und Bon Constrictor. The Vampire does not make use of his feet to walk, but to stretch a membrane, which enubles him to go up into an element where no other quadruped is seen. The Armadillo has only here and there n stringgling hair, and has neither fur, nor wool, nor bristles, but in lieu of them has received a movuble sicell, on which are scales very much like those of fishes. The Tortoise is oviparous, entirely without uny nppenrance of hair, and is obliged to accommodnte itself to n shell which is quite hard and inflexible, and in no point of view whatever, obedient to the will or plensure of the benrer. The egg of the Tortoise has a very hard shell, while that of the turtle is quite soft.

The Vauilla. In some parts of these forests I saw the Vanilla growing luxuriantly. It creeps up the trees to the beight of thirty or forty feet. I found it difficult to get a ripe pod as the monkies ure very fond of it, and generally took care to get there before me. The poc 1 \& from the tree in the shape of $n$ little scabbard. Vayna is the Spanish for a senbbard, and Vanilln for a little scabbard Hence the uane. 
In Mibiri ereek there was a Cayman of the small spe- Tura cies, measuring about five feet in length; $I$ saw it in Shoots a the same place for months, but could never get a shot at $\begin{gathered}\text { Cayman in } \\ \text { yiribi }\end{gathered}$ it ; for the moment $I$ thought $I$ was sure of it, it dived creek. under the water before I could pull the trigger. At last I got an Indian with his bow and arrow; he stood up in the canoe with his bow ready bent, and as we drifted past the place le sent his arrow into the Cayman's eye, and killed it dead. The skin of this little species is much harder and stronger than that of the large kind; it is good food, and tastes like veal.

My friend, Mr. Edmonstone, had very kindly let me Negro serhave one of his old negroes, and he constantly attencled me; his name was Daddy Quashi; he had a brave stomach for heterogeneous food ; it could cligest, and relish too, Caymen, monkies, hawks, and grubs. The Daddy made three or four meals on this Cayman while it was not absolutely putrid, and salted the rest. I could never get him to face a snake; the horror he betrayed on seeing one was beyond description; I asked him why he was so terribly alarmed; he said it was by secing so many dogs, from time to time, killed by them.

Here I had a fine opportunity of examining several species of species of the Caprimulgus. I an fully persuaded that mulgus. these innocent little birds never suck the herds; for when they appronch them, and jump up at their udders, it is to catel the flies and insects there. When the 
Thin n

JoURNEY.

moon shone bright, I would frequently go and stand within three yards of a cow, and distinctly see the Caprimulgus catch the flies on its udder. On looking for them in the forest, during the day, I either found them on the ground, or else invariably sitting longitudinally on the branch of a tree, not crosswise like all other birds.

The Wasps, or Maribun. tas.

Time and experience have convinced me that there is not much danger in roving amongst snakes and wild beasts, provided only that you have self-command. You must never approach them abruptly; if so, you are sure to pay for your rashness ; because the idea of self-defence is predominant in every animal, and thus the snake, to 
defend himself from what he considers an attack upon him, makes the intruder feel the deadly effect of his poisonous fangs. The Jaguar flies at you, and knocks you senseless with a stroke of his paw ; whereas, if you had not come upon him too suddenly, it is ten to one but that he had retired, in lieu of disputing the path with you. The Labarri snake is very poisonous, and I have often approached within two yards of him without fear. I took care to move very softly and gently without moving my arms, and he always allowed me to have a fine view of him, without showing the least inclination to make a spring at me. He would appear to kecp his eye fixed on me, as though suspicious, but that was all. Sometimes I have taken a stick ten feet long, and placed it on the Labarri's back. He would then glide away without offering resistance. But when I put the end of the stick abruptly to his head, he immediately opened his mouth, flew at it, and bit it.

One day, wishful to see how the poison comes out of Catches a the fing of the snake, I caught a Labarri alive. He was snake. about eight feet long. I held him by the neck, and my hand was so near his jaw, that he had not room to move his heal to bite it. This was the only position I could have held him with safety and effeet. To do so, it only required a little resolution and coolness. I then took a sinall piece of stick in the other hand, and pressed it against the fang, which is invariably in the upper jaw. 
THIRD JOURNEY.

Towards the point of the fung, there is a little oblong aperture on the convex side of it. Through this, there is a communication down the fing to the root, at which lies a little bag containing the poison. Now, when the point of the fing is pressed, the root of the fing also presses against the bag, and sends up a portion of the poison therein contained. Thus, when I applied a piece of stick to the point of the fung, there came out of the hole a liquor thick and yellow, like strong camomile tea. This was the poison, which is so dreadful in its effects, as to render the Laburiri snake one of the most poisonous in the forests of Guinna. I once caught a fine Labarri, and made it bite itself. I forced the poisonous fang into its belly. In a few minutes $I$ thought it was going to dic, for it appeared dull and heavy. However, in half an hour's time, he was as brisk and vigorous as ever, and in the course of the day showed no symptoms of being affected. Is then the life of the snake proof against its own poison? This subject is not unworthy of the consideration of the naturalist.

The Bete. In Guiana there is a little insect in the grass, and on rouge. the shrubs, which the French call Bete-ronge. It is of a beautiful scarlet colour, and so minute, that you must bring your eye close to it before you can perceive it. It is most numerous in the rainy season. Its bite causes an intolerable itching. The best way to get rid of it, is to rub the part affected with oil or rum. You must be care- 
ful not to serateh it. If you do so, and break the skin, you expose yourself to a sore. The first year $I$ was in Timad JounNXY. Guiana, the Bete-rouge, and my own want of knowledge, and, I may add, the little attention I paid to it, created an uleer above the ancle, which annoyed me for six months, and if $I$ lobbled out into the grass, a number of Bete-rouge would settle on the edges of the sore, and increase the inflammation.

Still more inconvenient, painful, and annoying is ano- The Chegoe. ther little pest, ealled the Chegoe. It looks exactly like a very small flea, and a strunger would take it for one. However, in about four and twenty hours, he would have severul broad hints that he had made a mistake in his ideas of the animal. It attacks different parts of the body, but chicfly the feet, betwixt the toe nails and the flesh. There it buries itself, and at first eauses an itching not umpleasant. In $\boldsymbol{n}$ day or so, after examining the part, you perceive a place about the size of a pea, somewhat discoloured, rather of a blue appearance. Sometimes it happens that the itching is so trivial, you are not aware that the miner is at work. Time, they say, makes great discoveries. The discoloured part turns out to be the nest of the Chegoe, containing hundreds of eggs, which, if allowed to hatch there, the young ones will soon begin to form other nests, and in time cause a spreading ulcer. As soon as you perceive that you have got the Chegoe in your flesh, you must take a needle, or a sharp pointed knife, 2 в 2 
Tutno JoURNEY.

and take it out. If the nest be formed, great eare must be tuken not to brenk it, otherwise some of the eggs remain in the flesh, and then you will soon be annoyed with more Chegoes. After removing the nest, it is well to drop spirit of turpentine into the hole; that will most effectually destroy nuy Chegoe that may be lurking there. Sometimes I have taken four nests out of my feet in the course of the dny.

Every evening, before sun down, it was part of my toilette to examine my feet, and see that they were clear of Chegoes. Now and then a nest would escape the scrutiny, and then I had to smart for it a day or two after. A Chegoe once lit upon the back of my hand; wishful to see how he worked, I allowed him to tnke possession. He immediately set to work, head foremost, and in about half an hour he had completely buried himself in the skin. I then let him feel the point of my knife, nud exterminnted him.

Ticks. More than once, after sitting down upon a rotten stump, I have found myself covered with Ticks. There is a short and easy way to get quit of these umwelcome adherents. Make a large fire and stand close to it, and if you be covered with Ticks, they will all fall off.

Let us now forget for a while the quadrupeds, scrpents, and insects, and take a transitory view of the native Indians of these forests.

There are five principal nations or tribes of Indians in 
ci-devant Dutch Guima, commonly known by the name

of Warow, Arowack, Acoway, Curib, and Macoushi. They live in small hamlets, which consist of a few huts, never exceeding twelve in number. These huts are always in the forest, near $\mathrm{n}$ river or some creek. They are open on all sides, (except those of the Macoushi,) and covered with a species of palm leaf.

Their principal furniture is the hammock. It serves Their hamthein both for chair and bed. It is commonly made of mocks. cotton ; though those of the Wurows are formed from the Fta tree. At night they alwnys make a fire close to it. The heat keeps them warm, and the smoke drives away the Mosquitos and sand-flies.- You sometimes find a table in the lut ; but it was not made by the Indians, but by soine negro, or mulatto carpenter.

They cut down about an acre or two of the trees :which Occupations surround the huts, and there plant pepper, Papaws, sweet and bitter Cassava, plantains, swect potatoes, yams, pineapples, and silk-grass. Besides these, they generally have a few acres in some fertile part of the forest for their Cassava, which is as bread to them. They make earthen pots to boil their provisions in ; and they get from the white men flat cireular plutes of iron, on which they bake their Cassava. They have to grate the Cassava before it is pressed, preparatory to baking; and those Indians who are too far in the wilds to procure graters from the white men, make use of a flat piece of wood, studded 
Tninv with sharp stones. 'They have no cows, horses, mules, Jounsky. gonts, sheep, or asses. The men hunt and fish, and the women work in the provision ground, and cook their victuals.

Fermented liguor.

In ench hanlet there is the trunk of a lurge tree, hollowed out like a trough. In this, from their Cassava, they muke an ubominable ill-tasted and sour kind of fernented liquor, ealled Piwarri. They are very fond of it, and never fuil to get drunk after every brewing. The frequency of the brewing depends upon the superabundance of Cassava.

Theirlubits. Both men and women go without clothes. The men have a cotton wrapper, and the women a bead-ornamented square piece of cotton, nbout the size of your hand, for the fig lenf. Those far awny in the interior, use the bark of a tree for this purpose. They are a very elem people, and wash in the river or creek, at least, twice every day. They paint thenselves with the Roucou, sweetly perfumed with Hayawn or Aceniari. Their hair is black and lank, and never curled. The women braid it up fancifully, something in the shape of Diana's hend dress in ancient pictures. They have very few disenses. Old age and pulmonary complaints seem to be the chief agents for removing them to another world. The pulmonary complaints are genecally brought on by a severe cold, which they do not know how to arrest in its progress, by the use of the lancet. I never saw an idiot annongst them, nor could I 
perecive any that were deformed from their birth. Their women never perish in ehild-bed, owing, no donbt, to their never wenring stnys.

They huve no public religious ecremony. They ne- Meligious knowledge two superior beings, - a good one, and a bud customs one. They pray to the latter not to luut them, and they monies. are of opinion that the former is too good to do them an injury. I suspeet, if the truth were known, the individuals of the village never offer up a single prayer or ejnenlution. They have a kind of a priest culled a Pee-ny-man, who is an enchunter. He finds out things lost. He mutters prayers to the evil spirit over them and their children when they are sick. If $\mathbf{a}$ fever be in the village, the Pee-ny-mum goes about all night long, howling, and making dreadful noises, and begs the bad spirit to depurt. But he lans very setdom to perform this part of his duty, as fevers seldoun visit the Indinn hamlets. However, when a fever does come, and his incantutions are of no avail, which $I$ imngine is most commonly the case, they abandon the place for ever, and make a new settlement elsewhere. They consider the owl and the goatsucker as fumiliars of the evil spirit, and never destroy them.

I could find no monuments or marks of antiquity amongst these Indians, so that after penetrating to the Rin Branco, from the shores of the Western Ocen, had any body questioned me on this subject, I should have answered, 1 have seen nothing anongst these Indians 
Tund which tells me that they have cxisted here for a Jounser. century; though, for aught I know to the contrary, they may have been here before the Redemption, but their total want of civilisation has assimilated them to the forests in which they wander. Thus, an aged tree falls and moulders into dust, and you camnot tell what was its appearanec, its beauties, or its diseases amongst the neighbouring trees; another has shot up in its place, and after nature has had her course, it will make way for a successor in its turn. So it is with the Indian of Guiana; he is now laid low in the dust; he has left no record behind him, either on parchment, or on a stone, or in earthenware, to say what he has done. Perhaps the place where his buried ruins lie was monenlthy, and the survivors have left it long ago, and gone far awny into the wilds. All that you ean say is, the trees where I stand appear lower and smaller than the rest, and from this I conjecture, that some Indians may have had a settlement here formerly. Were I by chance to meet the son of the father who moulders here, he could tell me that his father was famous for slaying tigers and serpents, and Caymen, and noted in the chase of the Tapir and wild boar, but that he remembers little or nothing of his grandfather.

They are very jealous of their liberty, and much attached to their own mode of living. Though those in the neighbourhood of the European settlements have constant communieation with the whites, they have no 
inelination to become civilized. Some Indiuns whos lunve accompanied white men to Europe, on returning to their 'Tiliav own hand, have thrown off their elothes, ind gone bnck into the forests.

In George-town, the capital of Demerm'n, there is a large shed, open on all sides, built for them by order of government. Hither the Indinns come, with monkien, parrots, bows and arrows, and Pegalls. 'Tliey sell these to the white men for money, and too often purchuse r'um with it, to which they are wonderfully uddicted.

Government allows them anmual presents in order to have their services, when the colony decme it nereessury to scour the forests in quest of rumaway negrower. liormerly these expeditions were healed by Churlix lidmomstone, Esq., now of Cardross-park, near Dumburtom. 'T'his brave colonist never returned from the wooks withont being vietorions. Once, in an attack upon the rebel ne. groes' camp, he led the way and received two bulls in his body ; it the same moment that he was wounded, fwo of his Indians fell dead by his side; he recovere'd ulter his life was despaired of, but the balls could never be extrincted.

I do not believe that there is a single lndiun in ri- cienerul derant Duteh Guiana who can read or writc, III) IIII 1 aware that any white man has reduced their longunge to the rules of grammar; some may have mude $\|$ sliort manuseript vocabulary of the few neeessury words, but that is all. Here and there a white mun, und some fow $2 \mathrm{c}$ 
Tarrd people of colour talk the language well. The temper of Jovnsey. the Indian of Guiana is mild and gentle, and he is very fond of his children.

Some ignorant travellers and colonists call these Indians a lazy race. Man in general will not be active without an object. Now when the Indian has caught plenty of fish, and killed game enough to last him for a week, what need has he to range the forest? He has no idea of making pleasure grounds. Money is of no use to him, for in these wilds there atre no markets for him to frequent, nor milliners' shops for his wife and daughters; he has no taxes to pay, no highways to keep up, no poor to maintain, nor army nor navy to supply; he lies in his hammock botlı night and day, (for he has no chair or bed, neither does he want them,) and in it he forms his bow, and makes his arrows, and repairs his fishing tackle. But as soon as he has consumed his provisions, he then rouses himself, and like the lion scours the forest in quest of food. He plunges into the river after the deer and Tapir, and swims across it ; passes through swamps and quagmires, and never fails to obtain a sufficient supply of food. Should the approach of night stop his career, while he is lumting the wild boar, he stops for the night, and continues the chase the next morning. In my way through the wilds to the Portuguese frontier 1 had a proof of this : we were eight in number, six Indians, a negro, and myself. About ten o'clock in the morning, 
we observed the feet-mark of the wild boars; we judged by the fresly s of the marks that they had passed that way early th. same morning. As we were not gifted, like the hound, with scent, and as we had no dog with us, we followed their track by the eye. The Indian after game, is as sure with his eye as the dog is with his nose. We followed the herd till three in the afternoon, then gave up the chase for the present; made our fires close to a creek where there was plenty of fish, and then arranged the hammocks. In an hour the Indians shot more fish with their arrows than we could consume. The night was beautifully serene and elear, and the moon shone as bright us day. Next morn we rose at dawn, got breakfust, packed up, each took his burden, and then we put ourselves on the track of the wild boars, which we had been following the day before. We supposed that they, too, would sleep that night in the forest, as we had done; and thus the delay on our part would be no disadvantage to us. This was just the ease, for about nine o'clock their feet-mark became fresher and fresher; we now doubled our pace, but did not give mouth like hounds. We pushed on in silence, and soon eame up with them; there were above one hundred of thent; we killed six, and the rest took off in different directions. But to the point.

Amongst us the needy man works from light to dark for a maintenance. Should this man chance to acquire 2 c 2 
a fortune, he soon chunges his habits. No longer under " strong necessity's supreme command," he contrives to get out of bed betwixt nine and ten in the morning. His servant helps him to dress, he walks on a soft carpet to his breakfust-table, his wife pours out his ten, and his servant hands him his tonst. After breakfast the doctor advises $n$ little gentle exercise in the carringe for an hour or so. At dimer-time he sits down to a table gromning beneath the weight of heterogeneous luxury : there he rests upon a chnir for three or four hours, cats, drinks, and talks (often ummenningly) till tea is announced. He proceds slowly to the drawing-room, and there spends best part of his time in sitting, till his wife tempts him with something wurm for supper. After supper, he still remains on his chuir at rest, till he retires to rest for the night. He mounts leisurely u] stairs upon a earpet, and enters his bed-room : there, one would hope, that at least he mutters a priyer or two, though perhaps not on bended linee : he then lets himself drop into a soft and downy bed, over which has just passed the comely Jenny's warming-pmu. Now, could the Indian in his turn see this, he would eull the white men a lazy, indolent set.

Perhnps then, upon due reflection, you would draw this conclusion; that men will always be indolent, where there is no olyject to rouse them.

As the Incliun of Guiann has no idea whatever of 
communicating his intentions by writing, he has fallen upon a plan of corrmunication sure and simple. When two or three families have determine $i$ to come down the Journey. river and pay an and communhand with a string of beads. You take one bead off every day; and on the day that the string is beadless, they arrive at your house.

In finding their way through these pathless wilds, the sun is to them what Ariadne's clue was to Theseus. When he is on the meridian, they gencrally sit down, and rove onwards again as soon as he has sufficiently declined to the west; they recuire no other compass. When in chase, they break a twig on the bushes as they pass by every three or four hundred paces, and this often prevents them from losing their way on their return.

You will not be long in the forests of Guiana before you perceive how very thinly they are inhabited. You may wander for a week together without seeing a hut. The wild beasts, the snakes, the swamps, the trees, the uncurbed luxuriance of every thing around you, conspire to inform you that man has no habitation here-man has seldom passed this way.

Let us now return to natural history. There was a person making shingles, with twenty or thirty negroes, not fur from Mibiri-hill. I had offered'a reward to any of them who would find a good sized snake in the forest, and come and let me know where it was. Often had 
these negroes looked for a large snake, and as often been disappointed.

One Sunday morning I met one of them in the forest, nnd asked him which way he was going : he said he was going towards Warratilla creek to hunt an Armadillo; and he had his little dog with him. On coming back, about noon, the dog began to bark at the root of a large tree, which had been upset by the whirlwind, and was lying there in a gradual state of decny. The negro said, he thought his dog was barking at an Acouri, which had probably taken refige under the tree, and he went up with an intention to kill it; he there saw a snake, and hastened back to inform me of it.

Goes in search of $a$ suakc.

The sum had just passed the meridian in a cloudless sky ; there was scarcely a bird to be seen, for the winged inhabitants of the forest, as though overeome by heat, had retired to the thickest shade : all would have been like midnight silence were it not that the shrill voice of the Pi-pi-yo, every now and then, resounded from a distant tree. I was sitting with a little Horace in my hand, on what had once been the steps which formerly led up to the now mouldering and dismantled building. The negro and his little dog cane down the hill in haste, and $I$ was soon informed that a snake had been discovered; but it was a young one, called the Bush-master, a rare and poisonous snake.

I instantly rose up, and laying hold of the eight-foot 
lance, which was close by me, “ Well then, Daddy," Tmin said I, "we'll go and have a look at the snake." I was Jounner. barefoot, with an old hat, and eleck shirt, and trowsers on, und a pair of braces to keep them up. The negro had his cutlass, and as we ascended the hill, another negro, armed with a cutlass, joined us, judining, from our pace, that there was something to clo. The little dog eame along with us, and when we had got about half a mile in the forest, the negro stopped, and pointed to the fallen tree : all was still and silent : I told the negroes not to stir from the place where they were, and keep the little dog in, and that $I$ would go in and reconnoitre.

$I$ advanced up to the place slow and cantious. The Finds and snake was well concealed, but at last I made him out ; it cunrmons was a Coulaeunara, not poisonous, but large enough to suake. have crushed any of us to death. On measuring him afterwards, he was something more than fourtcen feet long. This speeies of suake is very rare, and much thicker, in proportion to his length, than any other snake in the forest. A Coulacanara of fourteen fect in length is as thick as a common Boa of twenty-four. After skinning this snake I could easily get my head into his mouth, as the singular formation of the jaws admits of wonderful extension.

A Dutch friend of mine, by name Brouwer, killed a Boa, twenty-two feet long, with a pair of stag's horns in his mouth: he had swallowed the stag, but could not 
get the homs down; so he had to wait in patience with that uncomfortuble mouthful till his stomach digested the body, and then the horns would drop out. In this plight the Dutchman found him as he was going in his canoe up the river, and sent a bull through his head.

On ascertaining the size of the serpent which the negro had just found, I retired slowly the way I came, and promised four dollars to the negro who had shown it to me, and one to the other who had joined us. Aware that the day was on the decline, and that the approach of night would be detrimental to the dissection, a thought struck me that I could take him alive. I imagined if I could strike him with the lanee behind the lead, and pin him to the ground, I might suceed in eapturing him. When I told this to the negroes, they begged and entreated me to let them go for a gun, and bring more force, as they were sure the snake would kill some of us.

I had been at the siege of Troy for nine years, and it would not do now to carry back to Greece, " nil decimo nisi dedecus anno." I mean, I had been in search of a large serpent for years, and now having come up with one, it did not become me to turn soft. So, taking a cutlass from one of the negroes, and then ranging both the sable slaves behind me, I told them to follow me, and that I would cut them down if they offered to fly. I smiled as I said this, but they shook their heads in silence, and seemed to have but a bad heart of it. 
When we got up to the place, the serpent had not stirred, but I could see nothing of his head, and I judged TIIRD by the folds of his body that it must be at the furthest side of his den. A species of woodbine had formed n complete mantle over the branches of the fallen tree, ulmost impervious to the rain, or the rays of the sun. Probably he had resorted to this sequestered place for a length of time, as it bore marks of an ancient settlement.

I now took my knife, determining to eut away the Prepares to

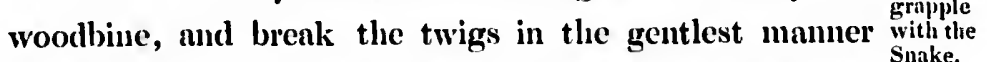
possible, till I could get a view of his hend. One negro stood guard elose behind me with the lunce; and near him the other with a cuthass. The cutlass which I had taken from the first negro, was on the ground close by me in ense of need.

After working in dead silence for a quarter of an hour, with one knee all the time on the ground, I had cleared away enongh to see his head. It appeared coming out betwixt the first and second coil of his body, and was flat on the ground. This was the very position I wished it to be in.

I rose in silence, and retreated very slowly, making a sign to the negroes to do the same. The dog was sitting at a distance in mute observance. I could now read in the face of the negroes, that they considered this as a very unpleasant affair; and they made another attempt 2 D 
THInD JoURNEY.

to persuade me to let them go for a gun. I smiled in a good-nutured manner, and made a feint to ent them down with the wenpon I had in my hand. This was all the answer I made to their request, and they looked very uneasy.

It must be observel, we were now about twenty yards from the snake's den. I now ranged the negroes behind me, and told him who stood next to me, to lay hold of the linee the moment 1 struck the snuke, and that the other must attend my movements. It now only remained to take their cutlasses firom them, for I was sure, if I clid not disurm them, they would be tempted to strike the snake in time of clanger, and thus for ever spoil his skin. On taking their eutlasses from them, if 1 might juclge from their physiognomy, they seemed to consider it as a most intolemble act of tyramy in me. Probably nothing kept them from bolting, but the consolation that I was to be betwixt them and the snake. Indeed, my own heart, in spite of all I could do, beat quicker than usual; and I felt those sensations which one has on board a merehant vessel in war time, when the captain orders all hands on deck to prepare for action, while a strange vessel is coming down upon us under suspicious colours.

We went slowly on in silence, without moving our arms or heads, in order to prevent all alarm as much as possible, lest the snake should glide off, or attack us in self-defence. I carried the lance perpendieularly before 
me, with the point about a foot from the ground. The snake had not moved; and on getting up to him, I struck him with the lance on the near side, just behind the JoURNEY. neck, and pinned him to the ground. That moment, the negro next to me seized the lance and held it firm in its place, while I dashed head foremost into the den to grapple with the suake, and to get hold of his thil before he could do any mischief.

On pinning him to the ground with the lance, le gave n tremendous lond hiss, and the little dog ran away, howling as he went. We had a sharp fray in the den, the rotten sticks flying on all sides, and each party struggling for superiority. I culled ont to the second negro to throw himself upon me, as 1 found $I$ was not licavy enough. He did so, mod the additional weight was of great service. I had now' got firm liold of his tail; ancl after $n$ violent struggle or two, he gave in, finding himself overpowered. This was the moment to secure him. So, while the first negro continued to hold the lance firm to the gromul, and the other wns helping me, I contrived to unloose my braces, and with them tied up the snake's mouth.

The snake, now finding himself in an unpleasant situation, tried to better hinself, and set resolutely to work, but we overpowered him. We contrived to make him twist himself round the shaft of the lance, and then prepared to convey him out of the forest. I stood at his 2 D 2 
head, and held it firm under my arm, one negro supported the belly, and the other the tail. In this order we began to move slowly towards home, and renched it after resting ten times; for the smake was too heavy for us to support him without stopping to recinit our strength. As we proceeded onwards with him, he fonght hard for frecdom, but it wns ull in vain. The day was now too fur spent to think of dissecting him. Hud I killed him, a purtial putrefuction would have tuken place before morning. I had brought with me up into the forest a strong bag, large enough to contain uny animal that I should want to dissect. I considered this the best mode of keeping live wild animuls when I was pressed for daylight ; for the bag yiclding in every direction to their efforts, they would have nothing solid or fixed to work on, and thus would be prevented from making " hole through it. I say fixed, for after the mouth of the ling was closed, the bag itself wns not fastened or tied to any thing, but moved about wherever the animal inside caused it to roll. After securing afresh the mouth of the Coulacanara, so that he could not open it, he was foreed into this bag, and left to his fute till morning.

I camnot say he allowed me to have a quict night. My hammock was in the loft just above him, and the floor betwixt us, half gone to decay, so that in parts of it no boards intervened betwixt his lodging room and mine. He was very restless and fretful; and had Medusa been 
my wife, there could not have been more continued and disagreenble hissing in the bed-chamber that night. At Timnd dnybreak, I sent to borrow ten of the negroes who were cutting wood at a distnnee; I could luve done with half that number, but juclged it most prudent to have a good forec, in case he should try to escape from the house when we opened the bag. However, nothing serious oceurred.

We untied the month of the bag, kept him down by kills and main foree, and then I ent his throat. He bled like an snake. ox. By six o'clock the same evening, he wus completely dissected. On exmunining his teeth, I observed that they were all bent like tenter-hooks, pointing down his throat, and not so lurge or strong ns I expeeted to huve found them ; but they are exactly suited to what they are intended by nature to perform. The smake does not masticate his food, and thus the only service his teeth have to perforan is to seize his prey, and hold it till he swallows it whole.

In general, the skins of snakes are sent to museums without the hend: for when the Indiuns and Negroes kill a snake, they seldom finil to cut off the hend, and then they run no risk from its teeth. When the skin is stuffed in the museum, $\mathbf{n}$ wooden head is substituted, anmed with teeth which are large enough to suit a tiger's jaw; and this tends to mislend the spectntor, and give him erroneous ideas.

During this fray with the serpent, the old negro, Daddy Qunshi, was in George-town procuring provisions, and just 
ThIRD JOURNEY.

Attachis another Snike. returned in time to help to take the skin off. He had spent best part of his life in the forest with his old master, Mr. Edmonstone, and amused me much in recounting their many adventures amongst the wild beasts. The Daddy had a particular horror of snakes, and frankly declured that he could never have fnced the one in question.

The week following, his eourage was put to the test, and he made good his words. It was a curious conflict, and took place near the spot where I had captured the large snake. In the morning I had been following a new species of paroquet, and the day being rainy, I had taken an umbrella to kecp the gun dry, and had left it under a tree; in the afternoon 1 took Daddy Quashi with me to look for it. Whilst he was searching about, curiosity took me towards the place of the late scene of aetion. There was a path where timber had formerly been dragged along. Here 1 obscrved n young Coulacanara, ten feet long, slowly moving onwards; I saw he was not thick enough to break my arm, in ease he got twisted round it. There was not a moment to be lost. I luid hold of his tail with the left hand, one knce being on the ground; with the right 1 took off my hat, and held it as you would hold a shield for defence.

The snake instantly turned, and eame on at me, with his head about a yard from the ground, as if to ask me, what business $I$ had to take liberties with his tail. I let 
him come, hissing and open-mouthed, within two locet of my face, and then, with all the force I whs imuster of, I drove my fist, shielded by my hat, full in his juws. He was stumned and confounded by the blow, min ere he could recover himself, I had seized his theont with both hands, in such a position that he could not hife ine; I then allowed him to coil himself romel my bonly, mad marehed oft with him as my lawful prizc. Ho pressed me hard, but not alarmingly so.

In the mean time, Daddy Quashi huving fonmol the umbrella, and having heard the noise which the liny oecasioned, was coming cautionsly up. As socul us he saw me, and in what company I was, he turned ulout muld ran off home, I after him, and shouting to incerense his fear. On scolding him for his cowadice, the uld rengue begged that 1 would forgive him, for thut the nightit. of the suake hud positively turned him sick nt stomunch.

When I had done with the careass of the lin'po: nunke, it was conveyed into the forest, as I expected thut it would attract the King of the Vultures, as soon us time slomlal have rendered it sufliciently savoury. In n fow diug it sent forth that odour which a carcass shomld nemel lintli, and about twenty of the common Vulturex enume mud perehed on the neighbouring trees; the King of the Vultures eame too; nud I observed thint nome of the commoin ones secmed inclined to begin linenkfinst till his majesty had finished. When he lind eomsmmed us much 
Tujad JOURNEY.

The King of the Vultures.

Its bill. snake as nature informed him would do him good, he retired to the top of a high Morn-tree, and then all the common Vultures fell to, and made $n$ hearty menl.

The head and neck of the King of the Vultures are bare of feathers; but the beautiful appearnnce they exhibit, fates in death. The throat and the back of the neck are of a fine lemon colour; both sides of the neck, from the ears downwards, of a rich scarlet; behind the corrugated part, there is a white spot. The crown of the head is scarlet; betwixt the lower mandible and the eye, and close by the ear, there is a part which has a fine silvery blue appearance; the corrugated part is of a dirty light brown ; behind it, and just above the white spot, a portion of the skin is blue, and the rest scarlet; the skin which juts out behind the neek, and appears like an oblong carmele, is blue in part, and part orange.

The bill is orange and black, the caruncles on his forehead ormge, and the cere orange; the orbits scmilet, and the irides white. Below the bare part of the neck there is a cinereous ruff. The bag of the stomach, which only appears when distended with food, is of a most delicate white, intersected with blue veins, which appear on it just like the blue veins appear on the arm of a finir-complexioned person. The tail and long wing-feathers are black, the belly white, and the rest of the body a fine satin colour.

I cannot be persuaded that the Vultures ever feed upon 
live animals, not even upon lizards, rats, mice, or frogs ; I have watched them for hours together, but never could see them touch any living animals, though innumerable lizards, frogs, and small birds swarmed all around them. I have killed lizards and frogs, and put them in a proper place for observation; as soon as they began to stink, the Aura Vulture invariably came and took them off. I lave frequently observed, that the day after the planter had burnt the trash in a cane-field, the Aura Vulture was sure to be there, feeding on the snakes, lizards, and frogs which had suffered in the conflagration. I often saw a large bird (very much like the common gregarious Vulture at a distance) catch and devour lizards; after shooting one, it turned ont to be not a Vulture, but a hawk, with a tail squarer and shorter than hawks have in general. The Vultures, like the goatsueker and woodpecker, seem to be in disgrace with man. They are generally termed a voracious, stinking, cruel, and ignoble tribe. Under these impressions, the fowler discharges his gun at them, and probably thisks he has done well in ridding the earth of such vermin.

Some govermments impose a fine on him who kills "Vulture. This is a salutary law, and it were to be wished that other governments would follow so good an eximple. I would fuin here say a word or two in favour of this valuable scavenger.

Kind Providence has conferred a blessing on hot coun2 E 
Third JOURNEY. tries in giving them the Vulture; he has ordered it to consume that which, if left to dissolve in putrefaction, would infect the nir, und produce a pestilence. When full of food, the Vulture certninly appears an indolent bird ; he will stand for hours together on the branch of a tree; or on the top of a house, with his wings drooping, and after rain, witlı them sprend and elevated to eatch the rays of the sun. It hins heen remarked by naturalists, that the flight of this hird is laborious. I have paid attention to the Vulture in Andalusia, and to those in Guiana, Brazil, and the West Indies, and conclucle that they are birds of long, even, und lofty flight. Indeed, whoever has observed the Aurn Vulture, will be satisfied that his flight is wonderfully mujestic, and of long continuance.

This bird is aloove five fect from wing to wing extended. You will see it sonring uloft in the acrial expanse on pinions which never flutter, and which at the same time carry him through the fickls of ether with a rapidity equal to that of the golden eagle. In Paramaribo the laws protect the Vulture, and the Spaniards of Angustura never think of, molesting lim. In 1808, I saw the Vultures in that city us tame as domestic fowls; a person who had never seen " Vulture would have taken them for turkies. They were very useful to the Spaniards; had it not been for them, the refuse of the slanghterhouses in Aligusturn would huve cuused an intolerable nuisance. 
The common black, short, square-tailed Vulture is gregarious ; but the Aura Vulture is not so; for, though you may see fifteen or twenty of them feeding on the dead vermin in a cane-field, after the trash has been set fire to, still, if you have paid attention to their arrival, you will have observed that they eane singly and retired singly; and thus their being all together in the same field was merely accidental, and eaused by cach one smelling the effluvia as he was soaring through the sky to look out for food. I have watched twenty eome into a cane-field; they arrived one by one, and from different parts of the heavens. Hence we may conclude, that though the other species of Vulture are gregarious, the Aura Vulture is not.

If you disseet a Vulture that has just been feeding on carrion, you must expect that your olfactory nerves will be somewhat offended with the rank effluvia from his craw ; just as they would be were you to dissect a eitizen after the lord mayor's dinner. If, on the contrary, the Vulture be empty at the time you coinmence the operation, there will be no offensive smell, but a strong scent of musk.

I had long wished to examine the native haunts of the Cayman; but as the river Demerara did not afford a speeimen of the large kind, I was obliged to go to the river Essequibo to look for one.

I got the canoe ready, and went down in it to George2 \& 2 
THIRD JOURNEY.

Sails in $n$

canoe down

to the Essequibo.

Suffers much pain in the feet from exces. sive heat. town; where, having put in the necessary articles for the expedition, not forgetting a couple of large sharkhooks, with chains attached to them, and a coil of strong new rope, I hoisted a little sail, which I lad got made on purpose, and at six o'clock in the morning shaped our course for the river Essequibo. I had put a pair of shoes on to prevent the tar at the bottom of the canoe from sticking to my feet. The sum was flaning hot, and from eleven o'clock till two beat perpendicularly upon the top of my feet, betwixt the shoes and the trowsers. Not fecling it disagreeable, or being in the least aware of painful consequence s, as I had been barefoot for months, I neglected to put on a pair of short stockings which I had with me. I did not reflect, that sitting still in one place, with your feet exposed to the sun, was very different from being exposed to the sun while in motion.

We went ashore, in the Essequibo, about three o'clock in the afternoon, to choose a place for the night's residence, to collect fire-wood, and to set the fish-hooks. It was then that I first began to find my legs very painful : they soon became much inflaned, and red, and blistered; and it required considerable caution not to burst the blisters, otherwise sores would have ensued. I immediately got into the hammock, and there passed a puinful and sleepless night, and for two days after, I was disabled from walking.

About midnight, as I was lying awake, and in great 
pain, 1 lleard the Indian say, “ Massa, massa, you no hear Tiger?" I listened attentively, and heard the softly JournEx. sounding tread of his feet as he approached us. The the night by sounding tread of his feet as he approached us. The a Jaguar moon had gone down; but every now and then we could Tiger. get a glance of him by the light of our fire : he was the Jaguar, for I could see the spots on his body. Hnd I wished to have fired at him I was not able to take a sure aim, for I was in such pain that I could not turn myself in my hammock. The Indian would have fired, but I would not allow him to do so, as $I$ wanted to see a little more of our new visitor; for it is not every day or night that the traveller is fivoured with an undisturbed sight of the Jaguar in his own forests.

Whenever the fire got low, the Jaguar came a little nearer, and when the Indian renewed it, he retired abruptly; sometimes he would come within twenty yards, and then we had a view of him, sitting on his hind legs like a dog; sometimes he moved slowly to and fro, and at other times we could hear him mend his pace, as if impatient. At last, the Indian not relishing the idea of having such company in the neighloourhood, conld eontain himself no longer, and set up a most tremendous yell. The Jnguar bounded off like a raee-liorse, and returned no more; it appeared by the print of his feet the next morning, that he was a full-grown Jiguar.

In two days after this we got to the first falls in the Reaches the Essequibo. There was a superb barrier of rocks quite Essequibo. 
THIR D JOURNEY.

across the river. In the rainy scason these rocks are for the most part under water ; but it being now dry weather, we had a fine view of them, while the water from the river above them rushed through the different openings in majestic graudeur. Here, on a little hill, jutting out into the river, stands the house of Mrs. Peterson, the last house of people of colour up this river; 1 hired a negro from her, and a coloured man, who pretended that they knew the haunts of the Cayman, and understood every thing about taking him. We were a day in passing these falls and rapids, celebrated for the Pacou, the richest and most delicious fish in Guiana. The coloured man was now in his element; he stood in the head of the eanoc, and with his bow and nrrow shot the Pacon as they were swimming in the stream. The arrow had searcely left the bow before he had plunged headlong into the river, and seized the fish as it was struggling with it. He dived and swm like an otter, and rarely missed the fish he aimed at.

Did my pen, gentle reader, possess deseriptive powers, I would here give thee an iden of the enchanting scenery of the Essequibo; but that not being the case, thou must be contented with a moderate and well-intended attempt.

Scenery. Nothing could be more lovely than the appearance of the forest on each side of this noble river. Hills rose on hills in fine gradation, all covered with trees of gigantic 
height and size. Here their leaves were of a lively purple, and there of the deepest green. Sometimes the Caracara extended its scarlet blossons from branci. , brunch, and gave the tree the appearance as though it had been hung with garlands.

This delightful scenery of the Essequibo made the soul overllow with joy, and eaused you to rove in fancy through fairy-land; till, on turning an angle of the river, you were recalled to more sober reflections on seeing the once grand and towering Mora, now dead and ragged in its topmost branehes, while its aged trunk, undermined by the rushing torrent, hung as though in sorrow over the river, which, ere long, would receive it, and sweep it away for ever.

During the day, the trade-wind blew a gentle and refieshing breeze, which died away as the night set in, and then the river was as smooth as glass.

The moon was within three days of being full, so that we did not regret the loss of the sum, which set in all its splendour. Searee had he sunk behind the westem hills, when the goatsuckers sent forth their soft and plaintive cries; some often repeating, "Who are youwho, who, who are yon?" and others, "Willy, Willy, Willy cone go."

The Indian and Daddy Quashi often shook their head at this, and said they were bringing talk from Yabahon, who is the evil spirit of the Essecpuibo. It was delightful 
THund JOURYEX.

The Cam. panero. to sit on the brunch of $\mathbf{n}$ fullen tree, near the water's edge, and listen to these humnless birds as they repeated their evening song; and watch the owls and vampires us they every now and then passed up and down the river.

The next day, nbout noon, as we were proceeding onwards, we heard the Campanero tolling in the depth of the forest. Though I should not then have stopped to disscet even a rare bircl, having a grenter object in view, still I could not resist the opportmnity offered of aecuiring the Campanero. The place where he was tolling was low and swampy, and my legs not having puite recovered from the effects of the sum, I sent the Indian to shoot the Campanero. He got up to the tree, which he described as very high, with a naked top, and situated in a swamp. He fired at the bird, but either missed it, or did not wound it sufficiently to bring it down. This was the only opportunity I had of getting a Campanero during this expedition. We had never heard one toll before this morning, and never heard one after.

About an hour before sunset, we renched the place which the two men, who had joined us at the falls, pointed out as a proper one to find a Cayman. There was a large creek elose by, and a sandbank gently sloping to the water. Just within the forest on this bank, we cleared a place of brushwood, suspended the hammocks from the trees, and then picked up enough of decayed wood for fuel. 
The Indian found a large land tortoise, and this, with plenty of fresh fish which we had in the canoe, afforded a supper not to be despised.

The tigers had kept up a continual roaring every night Roaring of since we had entered the Essequibo. The sound was awfully fine. Sometimes it was in the immedinte neighbourhood; at other times it was far off, and echoed amongst the hills like distant thunder.

It may, perhaps, not be amiss to observe here, that when the word tiger is used, it does not mean the Bengal tiger. It menns the Jnguar, whose skin is beautifully spotted, and not striped like that of the tiger in the East. It is, in fact, the tiger of the new world, and receiving the name of tiger from the discoverers of South America, it has kept it ever since. It is a cruel, strong, and dangerous beast, but not so courngeous as the Bengal tiger.

We now baited a shark-hook with a large fish, and put it upon $\mathbf{n}$ board about n yard long, and one foot broad, which we had brought on purpose. This board was carried out in the canoe, nbout forty yurds into the river. By menus of a string, long enough to reach the bottom of the river, and at the end of which string was fastened a stone, the board was kept, as it were, at anchor. One end of the new rope I had bought in town, was reeved through the chain of the shark-hook, and the other end fastened to a tree on the sand-bank. 
Tuind JoUnney.

Noise of the Caymen.
It was now an hour nfter sunset. The sky was cloudless, and the unoon shone benutifully bright. There was not a breath of wind in the henvens, and the river seemed like a large plain of quicksilver. Every now and then a luge fish would strike and plunge in the water; then the owls and goatsuckers would continue their lamentations, and the sound of these was lost in the prowling tiger's growl. Then all was still again and silent as midnight.

The Caymen were now upon the stir, and at intervals their noise could be distinguished amid that of the Jaguar, the owls, the goatsuckers, and frogs. It was a singular and awful sound. It was like a suppressed sigh, bursting forth all of a sudden, and so loud that you might henr it above a mile off. First one emitted this horrible noise, and then another answered him ; and on looking at the countenances of the people round me, I could plainly see that they expected to have a Cayman that night.

We were at supper, when the Indian, who seemed to have had one eye on the turtle-pot, and the otl,er on the bait in the river, snid he saw the Cayman coming.

Upon looking towards the place, there appeared something on the water like a black log of wood. It was so unlike any thing alive, that I doubted if it were a Cnyman; but the Indian siniled, and said he was sure it was one; for he remembered seeing a Cayman; some years ago, when he was in the Essequibo.

At last it gradually appronehed the bait, and the board 
began to move. The moon shone so bright, that we conld distinctly see him open his huge jaws, and take in the bait. We pulled the rope. He immediately let drop the bait; and then we saw his black head retrenting from the board, to the distmee of a few yards; and there it remained cquite motionless.

He did not seem inclined to advance agnin; and so we finished our supper. In about an hour's time he again put himself in motion, and took hold of the !nit. But, probnbly, suspeeting that he hacl to deal with linnves and ehents, he held it in his month, but did not swallow it. We pulled the rope again, but with no better suecess thin the first time.

He retreated as usual, and came back again in about an hour. We prid him every attention till three o'clock in the morning; when, worn out with disuppointment, we went to the hanmocks, turned in, and fell asleep.

When day broke, we found that lie had contrived to get the bnit from the hook, though we had tied it on with string. We had now no more hopes of taking a Cnyman, till the retum of night. The Indim took off into the woods, and brought back a noble supply of game. The rest of us went into the cunoe, and proceeded up the river to shoot fish. We got even more thm we could use.

As a proached the shallows, we could see the large Sting nys moving at the bottom. The coloured man $2 \times 2$ 
Tutro JounNFY.

Birds.

Turtle's nests. never failed to hit them with his arrow. The weather was delightful. There was scarcely a cloud to intercept the sun's rays.

I saw several scarlet Aras, Anhingas, and ducks, but could not get a shot at them. The parrots crossed the river in innumerable quantities, always flying in pairs. Here, too, I saw the Sun-bird, called Tirana by the Spaniards in the Oroonoque, and shot one of them. The black and white searlet-headed Fineh was very common here. I conld never sce this bird in the Demerara, nor hear of its being there.

We at last came to a large sand-bank, probably two miles in circumference. As we approached it we could sec two or three hundred fresh-water turtle on the edge of the bank. Ere we eould get near enough to let fly an arrow at them, they had all sunk into the river and appeared no more.

We went on the sand-bank to look for their nests, as this was the breeding season. The coloured man showed us how to find them. Wherever a portion of the sand seemed smoother than the rest, there was sure to be a turtle's nest. On digging down with our hands, about nine inches deep, we found from twenty to thirty white eggs; in less than an hour we got above two hundred. Those which had a little black spot or tivo on the shell we ate the same day, as it was a sign that they were not fresh, and of course would not keep : 
those which had no speck were put into dry sand, and were good some weeks after.

At midnight, two of our people went to this mund-lumk, while the rest staid to watch the Cayman. The turtle hind advanced on to the sand to lay their eggs, and the men got betwixt them and the water; they brought off hulf $n$ dozen very fine and well-fed turtle. The egh-mhell of the fresh-water turtle is not hard like that of the lund tortoise, but appears like white parchment, and gives way to the pressure of the fingers; but it is very tomph, und does not brenk. On this sandi-bank, close to the forest, we found several Guana's nests; but they hud nover more than fourteen eggs a-piece. Thus paswed the diny in exercise and knowledge, till the sun's cleclining orb reminded us it was time to return to the pline from whence we had set out.

The second night's attempt upon the Cnymun was a repetition of the first, (quite unsuceessful. Wo wont a fishing the day after, had excellent sport, ind roturned to experience a third night's disappointment. (In the fourth evening, about four o'clock, we begmin to crocit a stage amongst the trees, close to the witer's odge. From this we intended to shoot an arrow into the Cnyman : at the end of this arrow was to be attuchied string, which would be tied to the rope, and "1, Noon n. the Cayman was struck, we were to hnve the cinnoe rendy, and pursue him in the river. 
THIRD JUURNEY

$\Lambda$ Couguar.

While we were busy in preparing the stage, a tiger began to roar. We judged by the sound that he was not above n quarter of a mile from us, and that he was close to tie side of the river. Unfortunately, the Indian said it was not a Jaguar that was roaring, but a Couguur. The ( ouguar is of a pale, brownish red colour, and not as large as the Jaguar. As there was nothing particular in this animal, I thought it better to attend to the apparatus for catching the Cayman than to go in quest of the Conguar. The people, however, went in the eanoe to the place where the Conguar was roaring. On arriving near the spot, they saw it was not a Couguar but an immense Jaguar, standing on the trunk of an aged Mora-tree, which bended over the river; he growled, and showed his teeth as they approached; the coloured man fired at him with a ball, but probably missed him, and the tiger instantly descended, and took off into the woods. I went to the place before dark, and we searched the forest for ubout half a mile in the direction he had fled, but we could see :10 traces of him, or nny marks of blood; so I concluded that fear hud prevented the man from taking steady aim.

We spent best part of the fourth night in trying for the Cayman, but all to no purpose. I was now convinced that something was materially wrong. We ought to have been successful, considering our vigilunce and nttention, and that we had repeatedly seen the Cayman. 
It was useless to tarry here any longer; moreover, the coloured man began to take airs, and fancied that I could not do without him. I never admit of this in any expedition where $I$ am commander; and so $I$ convinced Turnd JOURNEY. the man, to his sorrow, that I. could do without him ; for I paid him what I had agreed to give him, which amounted to eight dollars, and ordered him back in his own curial to Mrs. Peterson's, on the hill at the first falls. I then asked the negro if there were any Indian settlements in the neighbourhood; he said he knew of one, a day and a half off. We went in quest of it, and about one o'clock the next day, the negro showed us the creek where it was.

The entrauce was so concealed by thick bushes that a Reaches a stranger would have passed it without knowing it to be creek and a creek. In going up it we found it dark, winding, and Indian setintricate beyond any creek that I had ever seen before. When Orpheus cane back with his young wife from Styx, his path must have been similar to this, for Ovid says it was

"Arduns, obliquus, caligine densus opaca,"

and this creek was exactly so.

When we had got about two-thirds up it, we met the Indians going a fishing. I saw, by the way their things were packed in the curial, that they did not intend to return for some days. However, on telling them what. we wainted; and by promising handsome presents 
Tnind of powder, shot, and looks, they dropped their expeJounsey. dition, and invited us up to the settlement they had just left, and where we laid in a provision of Cassava.

Indian They guve us for dinner boiled ant-bear and red monkey; two dishes unknown even at Beauvilliers in Paris, or at a London city feast. The monkey was very good indeed, but the mut-bear had been kept beyond its time; it stunk like our venison does in England; and so, after tasting it, I preferred dining entirely on monkey. After resting here, we went back to the river. The Indinns, three in number, nceompanied us in their own curial, and, on entering the river, pointed to aplace a little way above, well culenlated to harbour a Cayman. The water was deep und still, and flanked by an immense sand-bank; there wns also \# little shallow ereek elose by.

On this sund-bunk, near the forest, the people made a shelter for the night. My own was alrendy made; for I always take with me a painted sheet, about twelve feet by ten. 'This, thrown over a pole, supported betwixt two trees, mukes you a capital roof with very little trouble.

We showed one of the Indians the shark-hook. He shook his hend and luughed at it, and said it would not do. When he was a boy, he had seen his father eatch the Caymen, and on the morrow he would make something that would unswer.

In the mann time, we set the shark-hook, but it availed 
us naught; a Cayman came and took it, but would not swallow it.

Seeing it was useless to attend the shark-hook any longer, we left it for the night, and returned to our hammocks.

Ere I fell asleep, a reflection or two broke in upon me. I considered, that as far as the judgment of civilized man went, every thing had been procured and done to ensure success. We had hooks, and lines, and baits, and patience; we had spent nights in watching, had seen the Cayman come and take the bait, and after our expectations had been wound up to the highest pitch, all ended in disappointment. Probably this poor wild man of the woods would succeed by menns of a very simple process; and thus prove to his more civilized brother, that notwithstanding books and schools, there is a vast deal of knowledge to be picked up at every step, whichever way we turn ourselves.

In the morning, as usual, we found the bait gone from the shark-hook. The Indians went into the forest to hunt, and we took the canoe to shoot fish, and get another supply of turtle's eggs, which we found in great ubundance on this large sand-bank.

We went to the little shallow creek, and shot some young Caymen, about two feet long. It was astonishing to see what spite and rage these little things showed when the arrow struck them; they turned round and bit it, and snapped at us when we went into the water to 
take them up. Daddy Qunshi boiled one of them for his dimer, and found it very sweet and tender. I do not see why it should not be as good as frog or veal.

The day was now deelining apace, and the Indian had made his instrument to take the Cayman. It was very simple. There were four pices of tough hard wood, a foot long, and about as thick as your little finger, and barbed at both ends ; they were tied round the end of the rope, in such a manner, that if you conceive the rope to be an arrow, these four sticks would form the arrow's head; so that one end of the four united sticks answered to the point of the arrow-head, while the other end of the sticks expanded at equal distances round the rope, thus-

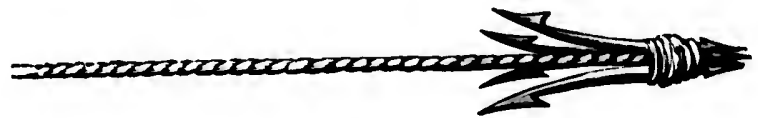

Now it is evident, that if the Cayman swallowed this, (the other end of the rope, which was thirty yards long, being fastened to a tree,) the more he pulled, the faster the barbs would stick into his stomach. This wooden hook, if you laay so call it, was well-baited with the flesh of the Acouri, and the entrails were twisted round the rope for about a foot above it.

Nearly a mile from where we had our hammocks, the sand-bank was steep and abrupt, and the river very still and deep ; there the Indian pricked a stick into the sand. It was two feet long, and on its extremity was fixed the machine; it hung suspended about a foot from the water, 
and the end of the rope was made fast to a stake driven well into the sand.

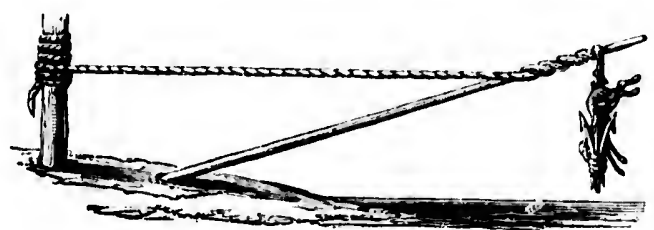

The Indian then took the empty shell of a land tortoise, and gave it some heavy blows with an axe. I asked why he did that. He said, it was to let the Cayman hear that something was going on. In fact, the Indian meant it as the Cayman's dinner-bell.

Having done this, we went back to the hammocks, not intending to visit it again till morning. During the night, the Jaguars roared and grumbled in the forest, as though the world was going wrong with them, and at intervals we could hear the distant Cayman. The roaring of the Jaguars was awful ; but it was music to the dismal noise of these hideous and malicious reptiles.

About half past five in the morning, the Indian stole succed in off silent'y to take a look at the bait. On arriving at the hooking a place, he set up a tremendous shout. We all jumped ont of our hammocks, and ran to him. The Indians got there before me, for they had no elothes to put on, and I lost two minutes in looking for my trowsers and in slipping into them.

We found a Cayman, ten feet and a half long, fast to 2 a 2 
Triad the end of the rope. Nothing now remained to do, but Journey. to get him out of the water without injuring his seales, " hoe opus, hic labor." We mustered strong : there were three Indians from the ereek, there was my own Indian Yan, Daddy Quashi, the negro from Mrs. Peterson's, James, Mr. R. Edmonstone's man, whoin I was instrueting to preserve birds, and, lastly, myself.

' informed the Indians that it was my intention to draw him quictly out of the water, and then secure him. They looked and stared at each other, and said, I might do it myself; but they would have no hand in it; the Cayman would worry some of us. On saying this, " consedere duces," they squatted on their hams with the most perfect indifference.

The Indians of these wilds have never been subject to the least restraint; and I knew enough of them to be aware, that if I tried to foree them against their will, they would take off, and leave me and my presents unheeded, and never return.

Daddy Quashi was for applying to our guns, as usual, considering them our best and safest friends. I immediately officed to knock him down for his cowardice, and he shrunk back, begging that I would be cautious, and not get inyself worried; and apologizing for his own want of resolution. My Indian was now in conversation with the others, and they asked if I would allow them to shoot a dozen arrows into him, and thus disable him. This would have ruined all. I had come above three 
hundred miles on purpose to get a Cayman uninjured, and not to carry back a mutilated specimen. I rejected their proposition with firmness, and darted a disdainful eye upon the Indians.

Daddy Quashi was again beginning to remonstrate, and I chased him on the sand-bank for a quarter of $\mathbf{n}$ mile. He told me afterwards, he thought he should have dropped down dead with fright, for he was firnly persuaded, if I had caught him, I should have bundled him into the Cayman's juws. Here then we stood, in silence, like a calm before a thunder-storm. "Hoc res summa loco. Scinditur in contraria vulgus." They wanted to kill him, and I wanted to take him alive.

I now walked up and down the sand, revolving a dozen projects in my head. The eanoe was at a considerable distance, and I ordered the people to bring it round to the place where we were. The mast was eight feet long, and not much thicker than my wrist. I took it out of the canoe, and wrapped the sail round the end of it. Now it appeared clear to me, that if I went down upon one knee, and held the mast in the same position as the soldier holds his bayonet when rushing to the charge, I could foree it down the Cayman's throat, should he come open-mouthed at me. When this was told to the Indinns, they brightened up, ind said they would help me to pull him out of the river.

“ Brave squad!" stid I to myself, " “Audax omnia take the perpeti,' now that you have got me betwixt yourselves alive. 
and clanger." I they mustered all hands for the last time before the battle. We ivere, four South American savages, two negroes from Africa, a Creole from Trinidad, and myself a white man from Yorkshire. In fact, a little tower of Babel group, in dress, no dress, address, and language.

Daddy Quashi lung in the rear; I showed him a large Spanish knife, which $I$ always carried in the waistband of my trowsers : it spoke volumes to him, and he shrugged up his shoulders in absolute despair. The sun was just peeping over the high forests on the eastem hills, as if coming to look on, and bid $x$ - sct with becoming fortitude. I placed all the people at the end of the rope, and ordered them to pull till the Cayman appeared on the surfice of the water; and then, should he plunge, to slacken the rope and let him go agnin into the deep.

I now took the must of the canoe in my hand (the sail being tied round the end of the mast) and sunk down upon one knce, about four yards from the water's edge, determining to thrust it down his throat, in case he gave me an opportunity. I certainly felt somewhat uncomfortable in this situation, and I thought of Cerberus on the other side of the Styx ferry. The people pulled the Cayman to the surface; he plunged furiously as soon as he arrived in these upper regions, and immediately went below again on their slackening the rope. I saw enough not to fall in love at first sight. I now told them we would run all risks, and have him on land immediately. 
They pulled again, and out he cane,- " monstrum, horrendum, informe." This was an interesting moment. I kept my position firmly, with my cye fixed steadfast on him.

By the time the Cayman was within two yards of me, I saw he was in a state of fear and perturbation; I instantly dropped the mast, sprung up, and jumped on his buck, turning half round as I vaulted, so that I gained my seat with my faec in a right position. I immediately seized his fore legs, and, by main force, twisted them on his back; thus they served me for a bridle.

He now seemed to have recovered from his surprise, and probably fancying himself in hostile company, he began to plunge furiously, and lashed the sand with his long and powerful tail. I was out of reach of the strokes of it, by being near his head. He continued to plunge and strike, and made my seat very uncomfortable. It must have been a fine sight for an unoccupied spectator.

The people roared out in trimmph, and were so voeiferous, that it was some time before they heard me tell them to pull me and my beast of burden farther in land. I was apprehensive the rope might break. and then there would have been every chance of going down to the regions under water with the Cayman. That would have been more perilous than Irion's marine morning ride :-

"Delphini insidens vada cærula sulcat Arion."

The people now dragged us above forty yards on the 
Thind JounNEY. sand: it was the first and last time I was cver on a Cayman's back. Should it be asked, low I munaged to keep my sent, I wonld answer,-I hunted some years with Lord Darlington's fox hounds.

After repented attempts to regnin his liberty, the Cnyman gave in, und beeane trancuil through exhaustion. I now managed to tie up his jaws, and firmly secured his fore feet in the position I had held them. We had now another severe struggle for superiority, but he was soon overcome, and again remuined quiet. While some of the people were pressing upon his head and shoulders, I threw myself on his tail, and by keeping it down to the sand, prevented him from kicking up another dust. He was finally conveyed to the camoe, and then to the place where we had suspended our hammocks. There I cut his throat; and nfter brenkfast was over, commenced the dissection.

Now that the affiray had censed, Daddy Quashi played a good finger and tlumb at brenkfust; he said he found himself much revived, and became very talkative and useful, as there was no longer any danger. He was a faithful, honest negro. His master, my worthy friend Mr. Edmonstone, had been so obliging as to send out particulnr orders to the colony, that the Daddy should attend me all the time I was in the forest. He had lived in the wilis of Demerara with Mr. Edmonstone for many -years; and often amused me witl the account of the frays his master had had in the woods with snakes, 
wild beasts, and runaway negroes. Old age was now coming fust upon him ; he had been an able fellow in his younger days, and a gallant one too, for he liad a lirge sear over his eyebrow, caused by the stroke of a cutlass, from rnother negro, while the Daddy was engaged in an intrigue.

The back of the Cayman may be said to be almost The back of impenetrable to a musket ball ; but his sides are not near the Cuyman. so strong, and are easily pierced with an arrow; indeed, were they as strong as the back and the belly, there would be no part of the Cayman's body soft and elastic enough to admit of expansion after tuking in a supply of food.

The Cayman has no grinders; his teeth ure entirely Its teeth. made for snateh and swallow; there are tli:ety-two in each ja:v. Perhaps no animal in existence bears more decided marks in his countenance of cruelty and malice than the Cayman. He is the scourge and terror of all the large rivers in South Amerien near the line.

One Sunday evening, some years ago, as I was walking Anecdote. with Don Felipe de Ynciarte, governor of Angustura, on the bank of the Oroonoque, "Stop here a minute or two, Don Carlos," said he to me, "while I recount a sad accident. One fine evening last year, as the people of Angustura were samtering up and down here, in the Alameda, I was within twenty yards of this place, when I saw a large Cayman l'ush out of the river, seize a man, 
Tuind JOURNEY.

and earry him down, before any body had it in his power to assist him. The sereams of the poor fellow were terrible as the Cayman was running off with him. He plunged into the river with his prey; we instantly lost sight of him, and never saw or heard him more."

I was a day and a half in dissecting our Cayman, and then we got all ready to return to Demerara.

It was much more perilous to descend than to ascend the falls in the Essequibo.

Great dangrer in descendingthe falls of the
Esseuuibo.

The plaee we had to pass had proved fatal to four Indians about a unonth before. The water foumed, and dashed and boiled amongst the steep and craggy rocks, and seemed to warn us to be eareful how we ventured there.

I was for all hands to get out of the canoe, and then, after loshing a long rope ahead and astem, we might have climbed from rock to rock, and tempered her in her passage down, and our getting out would lave lightened her much. But the negro who had joined us at Mrs. Peterson's, said he was sure it would be safer to stay in the eanoe while she went down the fall. I was loath to give way to him; but I did so this time against my better judgment, as he assured me that he was accustomed to pass and repass these falls.

Accordingly we determined to push down: I was at the helm, the rest at their paddles. But before we got half way through, the rushing waters deprived the canoc 
of all power of steernge, and she became the nport of the torrent; in a second she was half full of witcr, and I cannot comprehend to this day why she did not go down; JoURney. luckily the people exerted themselves to the utmost, she got headway, and they pulled through the whirlpool: I being quite in the stern of the emoc, purt of " wave struck me, and nearly knoeked me overhonrd.

We now paddled to some rocks nt $₫$ dintunce, pot out, unloaded the canoe, and dried the con'go in the sun, which was very hot and powerful. Had it heon the wet season, almost every thing would have beon spoiled.

After this, the voyage down the Exsecpuilon wus quick and pleasmit till we reached the sen-const: there! we had a trying day of it; the wind was dend ngunins us, and the sun remarkably lot; we got twice nuroumi "1pon a mudflat, and were twice obliged to get onf, "1) to the middle in mud, to shove tire canoe thromgli it. Hulf wny betwixt the Essequibo and Demernin the tide of flood caught us; and after the utmost exertions, it wis half past six in the evening before we got to (icorko-fown.

We had been out from six in the morning in III open Reaches canoe on the sea-coast, without umbrellu of uwning, cown. exposed all day to the fiery rays of a tropicul win. My face smarted so that I could get no slecep diuring the night, and the next morning my lips were $n$ ill in hlisters. The Indian Yan went down to the Esso(puib) " (oppere colour, but the reflection of the sun from flic ne'l, mind 2 ॥ 2 
Turnd JOURnEY.

from the sard-banks in the river, had turned him nearly black. He laughed at himself, and said the Indians in the Demerara would not know him again. I staid one day in George-town, and then set off the next morning for head-quarters in Mibiri creek, where I finished the Cayman.

Here the remaining time was spent in collecting birds, and in paying particular attention to their haunts and economy. The rainy season having set in, the weather became bad and stormy; the lightning and thunder were incessant; the days eloudy, and the nights cold and misty. I had now been eleven months in the forests, and collected some rare insects, two hundred and thirty birds, two land tortoises, five Armadillas, two large serpents, a sloth, an ant-bear, and a Cayman.

I left the wilds and repaired to George-town to spend a few days with Mr. R. Edmonstone previous to embarking for Europe. I must here return my sincerest thanks to this wortly gentleman for his many kindnesses to me ; his friendship was of the utmost service to me, and he never fated to send me supplies up into the forest by every opportunity.

Embarks I embarked for England, on board the Dee West Indiafor Englind. man, commanded by Captain Gray.

Sir Joseph Banks had often told me, he hoped that I would give a lecture in public, on the new mode I had discovered of preparing speeimens in natural history for 
museunns. I always declined to do so, as I despaired of ever being able to hit upon a proper method of doing quadJounney. rupeds; and $I$ was aware that it would have been an imperfect lecture to treat of bircls only. I imparted what little knowledge I was master of, at Sir Joseph's, to the unfortunate gentlemen who went to Africa ito explore the Congo; and that was all that took place in the shape of a lecture. Now, that $I$ had hit upon the way of doing quadrupeds, I drew up a little plan on board the Dee, which I trusted would have been of service to naturalists ; an! by proving to them the supcriority. of the new plan, they would probably be induced to abandon'the old and common way, which is a disgrace to the present age, and renders hideous cvery specimen in every nuseum int I have as yet visited. I intended to have given three . 4 ires : one on insects and serpents ; one on birds; and one on quadrupeds. But, as it will be shortly seen, this little plan was doomed not to be unfolded to public view. nliberality blasted it in the bud.

We had a pleasant passage across the Atlantic, and nrrived in the Mersey in fine trim and good spirits. Great was the nttention 1 received from the commander of the Dee. He and his mate, Mr. Spence, took every care of my collection.

On our landing, the gentlemen of the Liverpool Custom- Arrives at house received me as an old friend and acquaintance, and Liverpool. obligingly offered their services. 
Twice before had 1 landed in Liverpool, and twice had I reason to admire their conduct and liberality. They linew I was incaponble of trying to introduce any thing contribund, und they were aware that I never dreamed of turning to profit the specimens I had procured. They considered thut I had left a comfortable home in quest of science; und that I had wandered into far-distant climes, and gone burefooted, ill clothed, and ill fed, through swmups und woods, to procure specimens, some of which had never been scen in Europe. They considered that it would be diflicult to fix a price upon specimens which had never been bonght or sold; and which never were to be ; us they were intended to ornament my own house. It wus hurd, they said, to have exposed myself, for yeurs, to dinger, und then be obliged to pay on returning to my nutive land. Under these considerations, they fixed " moderute duty, which satisfied all parties.

However, this last expedition ended not so. It taught me how lined it is to learn the grand lesson, " aequam memento rebus in urduis, servare mentem."

But my good friends in the Custom-house of Liverpool were not to blume. On the contrary, they did all in their power to procure balm for me instead of rue. But it would not nuswer.

They uppointed a very civil oflicer to attend me to the ship). While we were looking into some of the boxes, to see thut the specimens were properly stowed, previous 
to their being conveyed to the King's depôt, another officer entered the cabin. He was an entire stranger to me, and seemed wonderfully aware of his own consequenee. Without preface or apology he thrust his head over my shoulder, and said, we had no business to have opened a single box without his permission. I answered, they had been opened almost every day since they had eome on board, and that I eonsidered there was no harm in doing so.

He then left the cabin, and I said to myself as he went out, I suspect I shall see that man again at Philippi. The boxes, ten in number, were conveyed in safety from the ship to the depòt, I then proceeded to the Custom-house. The necessary forms were gone through; and a proportionate duty, according to circumstances, was paid.

This done, we returned from the Custom-honse to the depòt, accompanied by several gentlemen who wished to see the collection. They expressed themselves highly gratified. The boxes were closed, and nothing now remained but to convey them to the curt which was in attendance at the door of the depòt. Just as one of the inferior officers was earrying a box thither, in stepped the man whom I suspected I should see again at Philippi. He abruptly declared himself dissatisfied with the valuation which the gentlemen of the enstoms had put upon the collection, and said he must detain it. I remonstrated, but it was all in vain. 
Tund After this pitiful stretch of power, and bad compliment Jounsar. to the other officers of the customs, who had been satisfied with the valuation, this man had the folly to take me aside, and after assuring me that he had a great regard for the arts and sciences, he lamented that conscience obliged him to do what he had done, and he wished he had been fifty miles fiom Liverpool at the time that it fell to his lot to detain the collection. Had he looked in my face as he said this, he would have seen no marks of credulity there.

I now returned to the Custom-liouse, and after expressing my opinion of the ofticer's conduct at the depot, I pulled a bunch of keys (which belonged to the detained boxes) out of my pocket, laid them on the table, took my leave of the gentlemen present, and soon after set off for Yorkshire.

I saved nothing from the grasp of the stranger officer, but a pair of live Malay fowls, which a gentleman in George-town had made me a present of. I had collected in the forest several eggs of curious birds, in hopes of introducing the breed into Englind, and had taken great pains in doing them over with gum arabic, and in paeking them in charconl, according to a receipt I had seen in the gazette, from the " Edinburgh Philosophical Joumal." But these were detained in the depôt, instead of being placed under a hen; which utterly ruined all my hopes of rearing a new species of birds in England. Titled 
personages in London interested themselves in behalf of the collection, but all in vain. And vain also were the public and private representations of the first officer of the Liverpool Custom-house in my favour.

At last there came an order from the Treasury to say, that any specimens $\mathrm{Mr}$. Waterton intended to present to public institutions might pass duty free; but those which he intended to keep for himself must pay the duty!

A friend now wrote to me from Liversw. requesting that I would come over and pay the duty, $m$ order to save the collection, which had just been detained there six weeks. I did so. On paying an additional duty, (for the moderate duty first imposed had already been paid,) the man who had detained the collection, delivered it up to me, assuring me that it had been well taken eare of, and that a fire had been frequently made in the room. It is but justice to add, that on opening the boxes, there was nothing injured.

I could never get a clue to these harsh and unexpected measures, exeept that ti. - ad been some recent smuggling discovered in Liverpoul ; and that the man in question had been sent down from London to act the part of Argus. If so, I landed in an evil hour"; " nefasto die ;" making good the Spanish proverb, " Pagan a las veces, justos por peculores ;" at times the innocent suffer for the guilty. After all, a little encouragement, in the shape of exemption from paying the duty on this collec- 
Tumo tion, might have been expected ; but it turned out otherJounssy. wise; and after expending large sums in pursuit of natural history, on my return home $I$ was doomed to pry for my success :-

" Hic finis, Caroli fatorum, hic cxitus illum, Sorte tulit!"

Thus, my fleece, already ragged and torn with the thorns and briars, which one must naturally expect to find in distant and untrodden wilds, was shom, I may say, on its return to England.

Conclusion. However, this is nothing new; Sancho Panza must have heard of similur cases; for he says, "Muchos van por lana, y vuclven trasquilados ;" many go for wool, and come home shorn. In order to pick up matter for natural history, I have wandered through the wildest parts of South America's equatorial regions. I have attacked and slain a moderu Python, and rode on the back of a Cayman close to the water's edge; a very different situation from that of a Hyde-park dandy on his Sunday prancer before the ladies. Alone and barefoot I have pulled poisonous snakes out of their lurking places ; climbed up trees to peep into holes for bats and vampires, and for days together hastened through sun and rain to the thickest parts of the forest to procure specimens I had never got before. In fine, I have pursued the wild beasts over hill and dale, through swamps and quagmires, now scorched by the noon-day sun, now 
drenched by the pelting shower, and returned to the hammock, to satisfy the cravings of hunger, often on a poor und seanty supper.

These vicissitudes lnve turned to chestnut hue a once English complexion, and changed the colour of my hair, before futher Time had meddled with it. The detention of the collection after it had fairly passed the Customs, and the subsequent order from the Treasury that $I$ should pay duty for the specimens, unless they were presented to some public institution, have east a damp upon my energy, and forced, as it were, the cup of Lethe to my lips, by drinking which $I$ have forgot my former intention of giving a lecture in public on preparing specimens to adom museums. In fine, it is this ungenerous treatment that has paralyzed my plans, and caused me to give up the idea I once had of inserting here the newly discovered mode of preparing quadrupeds and serpents; and without it, the account of this last expedition to the wilds of Guiama is nothing but a--fragment.

Furewell, Gentle Reader. 


\section{FOURTH JOURNEY.}

" Nusc luc, nunc illuc et untrinque sine ordine curro."

Fourti JovRNEY.

Courteous reader, when I bade thee last farewell, I thonght these wanderings were brought to a final close; afterwards I often roved in imagination through distunt countries fumous for matural history, but felt no strong inclination to go thither, as the last adventure had terminated in such unexpected vexation. The departure of the cuckoo and swallow, and summer birds of passage, for warmer regions, once so interesting to me, now scarcely eaused me to turn my fice to the south; and I continued in this cold and dreary climate for three years. During this period, I seldom or ever mounted my hobby-horse; indeed, it may be said, with the old song-

"The saddle and bridle were laid on the shelf,"

and only taken down once, on the night that I was induced to give a lecture in the philosophical hall of 
Leeds. A little after this, Wilson's " Ornithology of Fourrn the United States" fell into my hands.

The desire I had of seeing that country, together with suils for the animated description which Wilson had given of the New York. birds, funned up the alınost expiring flane. I forgot the vexations alrendy ulluded to, and set off for New York, in the beautiful packet John Wells, communded by Captnin Harris. The passage was long and cold; but the elegant necommodations on board, and the polite attention of the commander, rendered it very agreenble; and I landed, in health and merriment, in the statcly capital of the new world.

We will soon pen down a few remarks on this magnificent eity, but not just now. I want to venture into the north-west country, and get to their great canal, which the world tulks so much about, though I fear it will be hard work to make one's way through bugs, bears, brutes, and buffuloes, which we Europeans imngine are so frequent and ferocious in these never.ending western wilds.

I left New York on a finc morning in July, without one Leares New letter of introduction, for the city of Albany, some Albany. hundred and eighty miles up the celebrated Hudson. I scldom care about letters of introduction, for I am one of those who depend much upon an accidental acquaintance. Full many a face do $I$ see, as I go wandering up and down the world, whose mild eye, and sweet and 
Fountu placid fentures, seem to beckon to me, and say, as it Journsy. were, "Spenk but eivilly to me, and I will do what I can for you." Such a ficce as this is worth more than a dozen letters of introduction; and such a face, gentle renler, I found on bonrd the stemm-bont from New York to the eity of Albany.

There was a great number of well-dressed laclies and gentlemen in the vessel, ull entire strangers to me. I funcied I could see several, whose countenunces invited an unknown wanderer to come and tuke a sent beside them; but there was one who encouraged me more thun the rest. I saw clearly that he was in Americun, and I judged, by his mamers and appeuranee, that he had not spent ull his time upon his native soil. I was right in this conjecture, for he nfterwards told me thut he had. been in Frunce and Einglind. I suluted him as one stranger gentleman ought to sidute inother when lie wants a little informution; nnd soon nfter, I dropped in a word or two by which he might conjecture that I was n foreigner; but I did not tell him so; I wished him to make the discovery himself.

He entered into conversation with the opemess and candour which is so remarkable in the American ; and in a little time observed that he presumed I was from the old country. I told him that I was, and added, that I was an entire stranger on board. I saw his eye brighten up at the prospect he had of doing a fellow-crenture a 
kind turn or two, nud he completely wron my regard by an affability which I shall newer forget. This obliging gentleman pointed out every thing that was grand and interesting as the stenm-hoat plied her course up the majestic Hudson. Here the Catskill mountains raised their lofty summit; and there the hills enme sloping down to the water's edge. Here he pointed to mu aged and venerable onk, which having eseaped the levelling axe of man, seemed almost to defy the blasting storm, and desolating hand of Time; and there, he bade me observe nn extended tract of wood, by which 1 might form nn iden how rich and grand the fince of the eountry had once been. Here it was that, in the great ar:L momentous struggle, the eolonists lost the day; and there, they carried all before them :-

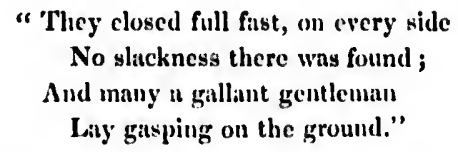

Here, in fine, stood a noted regiment ; there, moved their great enptain; here, the fleets fired their broadsides; and there the whole force rushed on to battle :-

" Hic Dolopum manus, hic maguns tendebat Achilles, Classibus hic locus, hic acies certure solebrt."

At ten-time we took our ten togeticer, and the next morning this worthy American walked up with me to the inn in Albany, shook me by the hand, and then went his 
Founes way. I bade him farewell, and again farewell, and JOURNEY. hoped that fortune might bring us together again once more. Possibly she may yet do so; and should it be in Englund I will take him to my house, as an old friend and acquaintance, and offer him my choicest cheer.

The great

It is at Albany that the great canal opens into the Hudson, and joins the waters of this river to those of Lake Erie. The Hudson, at the city of Albany, is distant from Lake Erie about three hundred and sixity. miles. The level of the lake is five hundred and sixtyfour feet higher than the Hudson, and there are eightyone locks on the eanal. It is to the genius and perseverance of De Witt Clinton, that the United States owe the almost incaleulable advantages of this inland navigation. " Exegit monumentum aere pereunius." You may either go along it all the way to Buffinlo, on Lake Erie, or by the stage; or sometimes on one and then in the scenery. other, just as you think fit. Grand, indeed, is the scenery by either route, and eapital the necommodations. Cold and phlegmatic must he be who is not warmed into admiration by the surrouncing seenery, and charmed with the affability of the travellers he meets on the way.

This is now the season of roving, and joy and merriment for the gentry of this happy comntry. Thousunds are on the move from different parts of the Union for the springs and lukes, and the fulls of Nicgara. There is nothing haughty or forbidding in the Americans; and 
wherever you meet them, they uppenr to be cuite at Fovrru home. This is exactly what it ought to bo, and very Jouneriv. much in favour of the foreigner who jommien monongst them. The immense number of highly polisherl femmales who go in the stages to visit the different plineer of numusement, and see the stupendous nuturnl cinriositicen of this extensive country, incontestubly proves timt muliety and convenience are ensured to them, nut thunt the most distant attempt at rudeness would, hy communn consent, be immediately put down.

By the time I had got to Schenectudy, I herentin strongly to suspect that I had come iuts) the wronke (omutry to look fo: bugs, bears, brutes, and bullulowe. It is an enchanting ,ourney from Allany to Schementmly, nud from thence to Lake Eric. 'The sitmution of the eity of Utica is particularly attractive; the Molunwk rumung close by it, the fertile fields and woody momitnilin, and the falls of Trenton, forcibly press the stringe(1) to stop a day or two here, before he proceeds onwered te the linke.

At some far distant period, when it will not bo powsible to find the plnee where many of the cerkinnaterel citices of the East once stood, the world will hunce lo flumilk the United States of America for bringing llovile numenes into the western regions. It is, indeed, " pretty thomght of these people to give to their rising towne flue numes of places so fimous and eonspienons in formene tinnew.

As I was sitting one evening under an onk, in the high 2 K 
Fouxun grounds behind Utica, I could not look down upon the Jourser. city without thinking of Cato and his misfortunes. Had the town been called Crofton, or Warmfield, or Dewsbury. there would have been nothing remarkable in it; but Utica at once revived the secnes at school long past and half forgotten, and carried me with full speed back again to Italy, and from thence to Africa. I crossed the Rubicon with Caesar; fought at Pharsalia; saw poor Pompey into Larissa, and tried to wrest the fatal sword from Cato's hand in Utien. When I perceived he was no more, I mourned over the noble-minded man who took that part which he thought would most benefit his country. There is something magnificent in the idea of a man taking by choice the conquered side. The Roman gods themselves did otherwise.

" Tictrix causa Diis placuit, sed victa Catoni."

"In this did Cato with the Gods divide,

The'y chose the concyuering, he the concyuer'd side."

Face of the country.

The whole of the comntry from Utica to Buffalo is pleasing; and the intervening of the inland lakes, large and deep and clear, adds considerably to the effect. The spacious size of the inns, their excellent provisions, and the attention which the traveller receives in going from Albany to Buffalo, must at once convince him that this comtry is very much visited by strangers; and he will draw the conclusion that there must be something in 
it uncommonly interesting to cause so many travellers to pass to and fio.

Nature is losing fast her ancient garb, and putting on a new dress in these extensive regions. Most of the stately timber has been carried away; thousands of trees are lying prostrate on the ground; while meadows, cornfields, villages, and pastures are ever and anon bursting upon the traveller's view as he jomrnies on through the remaining tracts of wood. I wish I could say a word or two for the fine timber which is yet standing. Spare it, gentle inhabitants, for your country's sake; these noble sons of the forest beantify your landseapes beyond all deseription; when they are gone, a century will not replace their loss; they camnot, they must not fall; their vernal bloom, their summer richness, and antumnal tints please and refresh the eye of man; and even when the days of joy and wamth are fled, the wintry blast soothes the listening ear with a sublime and plensing melancholy as it howls through their naked branches.

\footnotetext{
"Around we trees umnumber'd rise, Beatutiful in various dyes.

The gloomy piuc, the poplar blue, The yellow beech, the sible yew; 'The slender fir, lhat tiper grows, The sturdy oalk, with broad-spread bonglis."
}

A few miles before you reach Buffalo the road is low and bad, and, in stepping out of the stage, I sprained my foot very severely; it swelled to a great size, and 2 k 2 
Fourti JoURNF.

Buffalo. enused me many a day of pain and mortification, as will be seen in the secpucl.

Buffalo looks duwn on Lake Erie, and possesses a fine and commodious imn. At a little distance is the Black Rock, and there you pass over to the Canada side. A stage is in wniting to convey you some sixteen or twenty miles down to the finls. Yomer before you reach the spot you hear the mighty rom of waters, and see the spray of the fur-fumed fills of Ningara, rising up like st column to the henvens, and mingling with the passing clouds.

The falls of Niugara.

At this stupendons casende of nature, the waters of the lake fall onc hundred aud seventy-six feet perpendicular. It hus been calculuted, I forget by whom, that the quantity of water discharged down this mighty fall, is six hundred and seventy thousind two humdred and fifty-five tons per minute. There are two large inms on the Canada side; but, after you have satisfied your curiosity in viewing the fnlls, and in secing the ranbow in the fonis far below where you are stumding, do not, I pray you, tarry long at cifher of them. Cross over to the Ameriean side, and there you will find a spacious inn, which has noarly all the sttractions; there you meet with great attention, and everỹ necommondation.

The day is passed in looking at the falls, and in sauntering up nud down the wooded and rocky environs of the Ningmit; and the evening is often eulivened by the merry diunce. 
Words can hardly do justice to the unaffected ease and elegance of the American ladies who visit the falls of Joursey. Niagara. The traveller need not rove in imagination lndies. througl: Cireassia in search of fine forms, or through England, France, and Spain to meet with polished fenales. The numbers who are continually arriving from ail parts of the Union confirm the justness of this remark.

I was looking one evening at a dance, being unable to join in it on account of the accident I had received near Buffalo, when a young Amcriean entered the ball-room with such a becoming air and grace, that it was impossible not to have been struck with her appearance.

" For blown wats like the springing flower

That sips the silver dew,

The rose was budded in her eheck, Just opening to the riew."

I conld not help feeling a wish to know where she had

"Intu such beanty spread, and blown so fair."

Upon incuiry, 1 found that she was from the eity of Albany. The more 1 looked at the fair Albanese, the more I was convinered that in the United States of Ameriea may be formd grace and beanty and symmetry equal to any thing in the old world.

I now for good and all (and well I might) gave up the idea of finding bugs, beirs, brutes, and buffaloes in this country, and was thoroughly satisfied that I had laboured 
Fourtil JOURNEY under a great mistake in suspecting that I should ever meet with them.

I wished to join in the dance where the finir Albanese was "to brisk notes in calcnce beating," but the stnte of my unlueky foot rendered it inpossible; and as I sat with it reclined upon a sofa, full many a passing gentlemau stopped to inquire the cause of my mixforture, presuming at the same time that I had got an atack of gout. Now this sumise of theirs always mortified me; for I never had a fit of gout in my life, and, moreover, never cxpect to have onc.

In many of the inns in the United States, there is an album on the table, in which travelless insert their arrival and departure, and now and then indulge in a little flissh or two of wit.

1 thought, under existing circumstunces, that there would be no harm in briefly telling my misadventure; and so, taking np the pen, I wrote whint follows; and was never after asked a single question about the gout.

“ C. Waterton, of Walton-hall, in the county of York, linglind, arrived at the falls of Ningara, in July, 1824, and begs leave to pen down the following dreadful accident :-

" He sprained his foot, and hurt his toe,

On the rough road near Bullalo.

It quite distresses him to stagger a-

Long the sharp rocks of famed Ningara. 
So thus he's doonsed to driuk the measure

Of pain, in lieu of that of ple:tsure.

On Hope's delusive pinions borne

He came for wrol, and goes back shorn.

$\boldsymbol{N}$. B.-Here lic alludes to nothing but

'Th' alventure of his toc and foot;

Save this,-lie sees all that which can

Delight and charm the soul of miu,

But fecls it not,-because his toe

And foot together plingue lim so."

I remember once to have sprained my ancle very violently many years ago, and that the loctor ordered me to loold it under the pump two or three times a day. Now, in the United States of America, all is upon a grand scale, except taxation; and I an convineed that the traveiler's ideas become much more enlarged as he joumies through the conntry. This being the case, I can easily aceount for the desire I felt to hold my sprained foot under the fall of Niagara. I descended the winding stairease which has been made for the acconmodation of travellers, and then hobbled on to the scene of action. As I lield my leg under the fall, I tried to meditate on the immense difference there was betwixt a house pump and this tremendous cascade of nature, and what effect it might have upon the sprain; but the magnitude of the subject was too overwhehming, and I was obliged to drop it.

Perhaps, incleed, there was an unwarrantable tincture of vanity in an miknown wanderer wishing to have it in his 
Fourtil JOURNEX. power to tell the world, that he had held his sprained font under a full of whter, which discharges six hundred and seventy thousand two hundred and fifty-five tous per minute. A gentle purling stream would have suited better. Now, it would have become Washington, to have quenched his battle-thirst in the full of Niagara ; and there was something royal in the iden of Cleopatra drinking pearl-vinegar, made from the grandest pearl in Egypt : and it became Caius Marius to send word, that he was sitting upon the ruins of Carthage. Here, we have the person suited to the thing, and the thing to the person.

If, gentle reader, thou wouldst allow me to indulge a little longer in this harmless pen-errantry, I would tell thee, that I have had my ups and downs in life, as well as other people; for I have climbed to the point of the conductor above the cross on the top of St. Peter's, in Rome, and left my glove there. I have stood on one foot, upon the Guardian Angel's head, on the castle of St. Angelo; and, as I have just told thee, I have been low down under the full of Niagara. But this is neither here nor there; let us proceed to something else.

When the pain of my foot had become less violent, and the swelling somewhat abated, I could not resist the inclination I felt to go down Ontario, and so on to Montreal and Quebec, and take Lakes Champlain and George in my way back to Albany.

Just as I had made up my mind to it, a fumily from the 
Bowling-green, in New York, who was going the same route, politely invited me to join their party. Nothing could be more fortunate. They were highly accomplished. The young ladies sang delightfully; and all contributed their portion, to render the tour plensant and amusing.

'I'rnvellers have already filled the world with deseriptions of the bold and sublime scenery from Lake krie to Quebec:-

\footnotetext{
"The fountain's full, the rivere's flow, 'The woody vallies, warm and low'; The windy summit, wild and high, Ronghly rushing to the sky."
}

And there is searec one of them who hats not described the achievements of former ancl latter times, on the different battle-grounds. Here, great Wolfe expired. Brave Montealm was carried, mortally wounded, through youder gate. Here fell the gallant Brock; and there General Sheaffee captured all the invaders. And in yonder harbour may be seen the mouldering remnats of British vessels. Their hour of misfortune has long passed away. The vietors have now no use for them in in inland lake. Some lave already sumk, while others, dismantled and half dismasted, are just above the water, waiting, in shattered state, that destiny which must sooner or later destroy the fairest works of man.

The excellence and despatch of the'steam-boats, together with the company which the traveller is sure to 2 L 
Fovrti JoUKNEY.

The Cunadians.

Fortitications ut Quebre. meet with at this time of the yenr, render the trip down to Montrenl and Quebec very agreenble.

The Cunndims are a cuict, und apparently a happy people. 'They nre very courteous and nffinble to strangers. On comparing them with the character which a eertain female traveller, a journalist, has thought fit to give them, the stringer might have grent doubts whether or not he were amongst the Cinndinns.

Montreal, Quebec, and the fulls of Montmorency, are well worth going to see. They nre making tremendous fortifications at Quchee. It will be the Gibraltar of the new worlk. When one considers its distance from Europe, and tukes a view of its powerful and enterprising neighbour, Virgil's remark at once rushes into the mind

"Sic vos non robis uidificatis arcs."

I left Montreal with regret. I hand the good fortune to be introduced to the Professors of the College. These futher's are a very learned and worthy set of gentlemen; and on my taking leave of them, I felt a heaviness at heart, in reflecting that I had not more time to cultivate their acquaintance.

In all the wny from Buffulo to Quebee, I only met with one bug ; and I cannot cren swear that it belonged to the United States. In going down the St. Lawrence, in the stean-boat, I felt something crossing over my neck; and on laying hold of it with my finger and thumb, it 
turned out to be a little half-grown, ill-conditioned bug. Fourtu Now, whether it were going from the Americun to the JoURNeY. Cannda side, or from the Canadn to the Ameriean, and had taken the advantage of my shoulders to ferry itself across, I could not tell. Be this as it may, I thought of my uncle Toby and the fly; and so, in lien of placing it upon the deck, and then putting iny thumb nail verticully upon it, I quietly chucked it amongst some baggage that was close by, and recommended it to get ashore by the first opportunity.

When we had seen all that was worth seeing in Quebee and at the fills of Montmorency, and had bein on board the enormous ship Columbus, we returned for a day or two to Montreal, and then proceceded to Saratoga by Lakes Champlain and George.

The steam-bont from Quelece to Montreal had ubove Irish emifive hundred Irish emigrants on board. They were going, " they hardly knew whither," far away from dear Ireland. It made one's heart ache to see them all huddled together, without any expectation of erer revisiting their native soil. We feared that the sorrow of leaving home for ever, the miserable accommodations on board the ship which had brought them away, and the tossing of the angry ocean, in a long and dreary voyage, would have rendered them callous to good behaviour. But it was quite otherwise. They conducted themselves with great propriety. Every American on board seemed to feel for 
Fovru them. Aud then " they were so full of wretchednessi. Jounsiy. Need and oppression sturved in their eyes. Upon their bucks humg langeged misery. The world was not their friend." Poor denir Irehund, excluimed in uged femmle as I was talking to her, I shall never see it my more! and then her tenes began to flow. Probably the seenery on the bankis of the St. Iawrence recalled to her mind the remembrince of spots once interesting to her :-

"The lovely daughter,-lovelies in her tears, 'The fond companion of her futher's years, Here silent stomd,-nenglect ful of her chatrins, Aul left her lover's for her father's urus. With louder pliants, the motleer spolie her woes, And biensed the ent, where every pletsure rose; And presioced her thoughtles: babes, with many a tear, And clisped them elowe, in sorrow doubly decis. White the fond hoshanti strove lo lend relief, In all the silent manline'ss of gricf."

We went a few mile's out of our route to talke a look at the onee formidable fortress of 'Ticonderago. It hats long been in mins, and seems as if it rere doomed to mombler quite away.

" Ever and anon there fills. lluge heips of hasiry mouldar'd walls.

But time has seen, that lifts the low Aud level liys the lofty lorow, Ins secn this min'd pile complete, Big with the vanity of state, But transient is the smile of fitte."

The scenery of Lake George is superb; the inn remarkably spacious and well attended; and the conveyances 
from thenee to Sarntoga, very good. He must be sorely aflicted with spleen and junndice, who, on his arrivul at Saratogn, remurks, there is nothing here worth eoming to sec. It is a gay and fishlionul,le pline; lus four uncommonly fine hotels ; its waters, for medicinul virtnes, me surpassed by none in the known world; and it is resorted to, throughout the whole of the summer, by foreigners and natives of the first considerntion. Sarutoga plensed me much; and ufforded n fair oppostmity of forming w pretty correct iden of the gentry of the United sitates.

There is a pleasing fimliness, and ease and becoming dignity in the Amerienn lindies; and the good humour, aud abience of all hamghtiness and puppyism in the gentlemen, must, no doubt, impress the traveller with clevated notions of the company who visit this famous spat.

During my stay locere, all was joy, and aftibility, and mirth. In the mornings the ladies played and sinng for IIs; and the evenings were genesully enlivened with the merey dince. Here 1 bade farewell to the chaming family, in whosc company I had passed so many happy dậs, and proceceled to Albaụ.

The stage stopped a little while in the town of Troy. Troy. tue name alone was guite sullicient to recall to the mind secues long past and gone. Poor king Prian! Nipoleon's sorrows, sad and piereing an they were, did not 
Fountu JOURNRY. comc up to those of this ill-fated Monarch. The Greeks first set his town on fire, and then began to bully :-

" Iuceusâ Danai clomiuantur in urbe."

One of his sons was slain before his fnee; " ante ora parentum, concidit." Another was erushed to mummy by boa constrictors ; " immensis orbibus angues." His eity was rased to the ground, “ jacet Ilion ingens." And Pyrrhus ran him through with his sword, " capulo tenus abdidit ensem." This last may be considered as a fortumate stroke for the poor old king. Had his life been spared at this juncture, he could not lave lived long. He must have died broken-hearted. He would have seen his son-in-law, once master of a noble stud, now, for want of a horse, obliged to carry off his finther, up hill, on his own back, " cessi et sublato, montem geni-. tore petivi." He would have heard of his grandson being thrown neck and heels from a high tower, " mittitur Astyanax illis de turribus." He would have been informed of his wife tearing out the eyes of king Odrysius with her finger nails, " digitos in perficla lumina condit." Soon after this, losing all appearance of woman, she became a bitch,

"Perdidit infelix, hominis post ommia formam,"

and rent the heavens with her howlings,

- " Exteruasque novo latratu terruit auras." 
Then, becoming distraeted with the remembrnnce of her misfortunes, "veterum memor illa malor'un," slie took off howling into the fields of Thrace,-

"Tum quoque Sithonios, ululavit moestn per ngros."

Juno, Jove's wife and sister, was henrd to declane, that poor Hecuba did not deserve so terrible a fitte,-

"I Ipsa Jovis conjuxquue somorifun",

Eventus llecubam meruisse neguverit illom,"

Had poor Prian escaped from Troy, onc thing, und only one thing, would have given him a simull 'ny of nativfacetion, viz. he would have heard of one of his dinughters nobly preferring to leave this world, inther thum live to become servant maid to old Grecinn lindien :-

“ Non ego Mỵrmidonum sedes, Dolnpminve nuperinux, Adspieiam, ant Ciraiis servitum mutribus ilu,"

At some future period, should a forcign minned force, or intestine broils, (all which heaven uvert,) brixe Troy to the dignity of a fortified city, Virgil's propllecey uny then be fulfilled,

"Atgue iterum ad Trojim magnus miltefur Achillew."

After leaving Troy, I passed through 1 finc countsy to Albany; and then proceeded by stean down the Hudvon to New York.

Travellers lesitate whether to give the preference to Plibade!Philadelphia or to New York. Philudelphint is cortuninly phint. 
Fovrti JOURNEY.

a noble eity, and its environs beautiful ; but there is a degree of quiet and sedateness in it, which, though no doubt very agreeable to the man of ealm and domestic habits, is not so attractive to one of speedy movements. The quantity of white marble which is used in the buildings, fives to Philadelphia a gay and lively appearance; but the sameness of the streets, and their crossing each other at right angles, are somewhat tiresome. The waterworks which supply the city, are a proud momument of the skill and enterprise of its inhabitants ; and the marlict is well worth the attention of the stranger.

When you go to Philadelphia, be sure not to forect to visit the Museum. It will afford you a great treat. Some of Mr. Peale's family are eonstantly in it, and are ever ready to show the curiosities to strangers, and to give them every necessary information. Mr. Peale has now passed his eightiech year, and appears to possess the vivacity, and, I may almost add, the activity of youth.

To the indefatigable exertions of this gentleman, is the western world indebted for the possension of this splendid Museum. Mr. P'eale is, moreover, an excellent artist. Look attentively, I pray you, at the portrait he has taken of himself, by desire of the State of Pennsylvania. On entering the room he appears in the act of holding up a curtain, to show you his curiosities. The effect of the light upon his head is infunitely striking. I have never seen any thing finer in the way of light and shade. 
The skeleton of the Mammoth is a national treasure. I could form but a faint idea of it by description, until I had seen it. It is the most mannificent skeleton in the world. The city ought never to forget the great expense Mr. Peale was put to, and the skill and energy he showed, during the many months he spent in searching the swamps, where these enormous bones had been concealed from the eyes of the world for centuries.

The extensive sfuares of this eity are ornamented with well-grown and luxuriant trees. Its unremitting attention to literature, might eause it to be styled the Athens of the United States. Here, learning and seience have American taken up their abode. The literary and philosophieal literature. associations, the enthusiasm of individuals, the actrity of the press, and the eheapness of the publications, ought to raise the name of Philadelphia to an elevated situation in the temple of knowledge.

From the press of this city came Wilson's famous "Ornithology." By observing the birds in their native haunts, he has been enabled to purge their histery of numberless absurdities, which inexperivneed theorists had infroduced into it. It is a pleasing anc a brilliant work. We have no description of birds in any European publieation that can come up to this. By perusing Wilson's "Ornithology" attentively before I left Finglaud, I knew where to look for the birds, and inmediately reeognised them in their native land. 
Fountr Jounnsy.

Whiteheaded, Eagles.
Since his time, I fear that the white-headed Eagles have been much thimned. I was perpetually looking out for them, but saw very few. One or two came now and then, and somed in lofty flight over the falls of Niagara. The Amcricuns ure proud of this bird in effigy, and their hearts rejoice when its banner is unfurled. Could they not then be persuaded to protect the white-headed Eagle, and allow it to glide in safety over its own native forests? Were I m American, I should think I had committed a kind of sucrilege in killing the white-headed Eagle. The Ibis was held sucred by the Egyptians; the Hollanders protect the stork; the vulture sits ummolested on the top of the houses in the city of Angustura ; and Robinred-breast, for his churity, is eherished by the English :-

$$
\begin{aligned}
& \text { "No buriul, these pretty babes } \\
& \text { Of uny man receives, } \\
& \text { Till Robin-red-breast paiufully, } \\
& \text { Didl corer them with leaves." }
\end{aligned}
$$

Poor Wilson wis smote by the hand of death, before he had finished his work. Prince Charles Buonaparte, nepliew to the lute emperor Napoleon, aided by some of the most scientific gentlemen of Pennsylvania, is continuing this vuluable und interesting publication.

New York. New York, with great propriety, may be called the commercial cupitnl of the new world :-

\footnotetext{
"Urbs augusta potens, nulli cessura."
}

* The fuult against grammar is lost in the beauty of the idea. 
Ere long, it will be on the coast of North America, what Tyre once was on that of Syria. In her port are the ships of all nations; and in her streets is displayed merchandise from all parts of the known world. And then the approach to it is so enchanting! The verdant fields, the woody hills, the farms, and comntry houses, form a beautifi!l landseape as you sail up to the city of New York.

Broadway is the principal street. It is three miles and Its streets, a half long. I am at a loss to know where to look for a street, in any part of the world, which has so many attractions as this. There are 1:o steam-engines to annoy you by filling the atmosphere full of soot and smoke; the houses have a stately appearance; while the eye is relieved from the perpetual saneness, which is common in most streets, by lofty and luxuriant trees.

Nothing cau surpass the appearance of the American American ladies, when they take their morning walk, from twelve to three, in Broadway. The stranger will at once see that they have rejected the extravagant superfluities which appear in the London and Parisian fashions; and have only retained as much of those costumes, as is becoming to the female form. This, joined to their own just notions of dress, is what renders the New York ladies so elegant in their attire. The way they wear the Leghorn hat deserves a remark or two. With us, the formal hand of the milliner binds down the brim to one fixed 
Fourtu shape, and that none of the handsomest. The wearer Jovn:ey. is obliged to turn her head full nimety degrees before she can see the person who is standing by her side. But in New York the ladies have the brim of the hat not fettered with wire, or tape, or riband, but quite free and mululating; and by applying the hand to it, they can concenl or expose as much of the face as circumstances recuire. This hicling and exposing of the face, by the by, is certainly a dangerous movement, and often fatal to the passing swain. I an convinced in my own mind, that many a determined and unsuspecting bachelor, has been shot down by this sudden maneuve, betore lie was anare that he was within reach of the battery.

The Ameriean ladies secm to have an abhorrence fand is very just one too,) of wearing eaps. When one conviders for a moment, that women wear the hair long, which nature has given them both for an ornament and to keep the head wam, one is apt to wonder, by what perversion of good taste, they can be induced to cnclose it in a cap. A mob cap), a lace (alp), a low cap, a high eap, a flat cap, a cap with ribands dangling loose, a cap with ribands tied under the chin, a peak cap, an angular cap, a round cap, and a pyramid cap! How would Canova's Venus look in a mob eap: If there be any ornament to the head in wearing a cap, it must surely be a false oruanent. The Anurican laclies are persuaded that the head ran be ornamented wiriout a eap. A 
rose-bud or two, a woodbine, or a sprig of eglantinc, look well in the braided hair ; and if there be raven locks, a lily or a snowdrop may be interwoven with effect.

Now that the packets are so safe, and make such quick passages to the United States, it would be as well if some of our head milliners would go on board of them, in lien of getting into the Diligence for Paris. 'They would bring back more taste, and less caricature. And if they could persuade a dozen or two of the firmer's servant girls to return with them, we should soon have proof positive, that as good butter and eheese may be made with the hair braided up, and a daisy or primrose in it, as butter and cheese made in a cap of barbarons shape; washed, perhaps, in soap-suds last new moou.

New York has very good hotels, and geutcel boarding- Hotels and honses. All charges inchuded, you do not pay above two houses. dollars a day. Little enongh, when you consider the capital accommodations, and the abundance of food.

In this eity, as well as in other's which I visited, every body seemed to walk at his ease. I could see nò inclination for jostling; no importinent staring at you; nor attempts to create a row in order to pick your pocket. I viould stand for an hour together in Broadway, to observe the passing multitude. There is certainly a gentleness in these people, both to be admired and imitated. I could see very few dogs, still fewer cats, and but a very small proportion of fat women in the streets of 
Founru New York. The elimate wns the only thing that I had JounNEY. really to lind fault with; and as the autumn was now approaching, I began to think of preparing for warmer regious.

Climate. Strungers are apt to get violent colds, on account of the sudden change of the ntmosphere. The noon would often be as warm as tropical weather, and the close of day cold and chilly. This must sometimes act with severity upon the newly-arrived stranger; and it requires more eare and circumspection than I an master of to guard against it. I contracted a bad and obstinate cough, which did not quite leave me till I had got under the regular heat of the sum, near the equator.

Its society. I may be asked, was it all good fellowship and civility during my stay in the United States? Did no forward person cause offence? was there no exhibition of drunkenness, or swearing, or rudeness; or display of conduct which disgraces civilized man in other countries? I answer, very fow indeed : scarce any worth remembering, and none worth noticing. These are a gentle and a civil people. Should a traveller, now and then in the long run, witness a few of the scenes alluded to, he ought not, on his return home, to adduce a solitary instance or two, as the custom of the country. In roving through the wilds of Guiani, I lave sometimes seen a tree hollow at heart, shattered and leafless; but I did not, on that aecount, condemn its vigorous neighbours, and put down 
a memorandum that the woods were bad; on the contrary, I made allowances: a thunderstorm, the whirlwind, a blight from heaven might have robbed it of its bloom, and caused its present forbidding appearance. And, in leaving the forest, I carried away the impression, that though some few of the trees were defeetive, the rest were an ornament to the wilds, full of uses and virtues, and capable of benefiting the world in a superior degree.

A man generally travels into foreign countries for his own ends; and I suspect there is seareely an instance to be found of a person leaving his own home solely with the intention of benefiting those anongst whom he is about to travel. A commercial speculation, curiosity, a wish for information, a desire to reap benefit from an aequaintance with our distant fellow-creatures, are the general inducements for a man to leave his own fire-side. This ought never to be forgotten; and then the traveller will journey on under the persuasion that it rather becomes him to court than expect to be courted, as his own interest is the chief object of his travels. With this in view, he will always render himself pleasant to the natives; and they are sure to repay his little acts of courtesy with anple interest, and with a fund of information which will be of great service to him.

While in the United States, I found our western brother a very pleasant fellow; but his portrait has been 
Foentu drawn in such different shades, by different travellers Jounser. who have been through his territory, that it recpuires a persomnl interview before $n$ correct idea can be formed of his true colours. He is very inquisitive; but it is quite wrong on that aceount to tax him with being of an impertinent turn. He merely interrogates you for information; and when you have satisfied him on that score, only ask him in your turn for an account of what is going on in his own country, and he will tell you every thing about it with great good humour, and in excellent language. He has certuinly hit upon the way (but I could not make out by what menus) of speaking a much purer English language than that which is in general spoken on the parent soil. This astonished me much; but it is really the case. Amongst his mmy good gunlities, he has one unenviable, and I may add, a bad propensity; he is immoderately fond of smoking. He may say, that he learned it from lis nurse, with whom it was once much in vogur. In Dutch William's time (he was a mmn of bad taste) the English gentleman could not do without his pipe. During the short space of time that eorporal Trim was at the inn incuiring ufter poor Lefevre's health. my uncle Toby had knocked the ashes out of three pipes. "It was not till my uncle Toby had knocked the ashes out of his third pipe," \&c. Now these times have luckily gone by, and the custom of smoking unongst genteel Englishmen has nearly died away with them; it is a foul 
custom; it inakes a foul mouth, ancl a foul place where the smoker stunds : however, every nation has its whims. Jolın Bull relishes stinking venison; a Frenchman depopulates whole swamps in cuest of frogs; a Dutchman's pipe is never out of his mouth ; a Russiun will eat tallow candles; and the American indulges in the cigar. “ De gustibus non est disputandum."

Our western brother is in possession of a country replete with every thing thut ea (nibute to the happiness and comfort of mankind. code of laws, purified

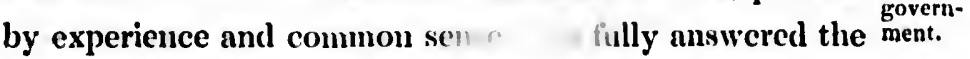
expectations of the public. By acting up to the true spirit of this code, he has reaped immense advantages from it. His advancement, as a nation, has been rapid beyond all calculation; and, young as he is, it may be remarked, without any impropriety, that he is now actunlly reading a salutury lesson to the rest of the civilized 'vorld.

It is but some forty years ago, that he liad the dispute with his nurse about a dish of ten. She wanted to force the boy to drink it according to her own receipt. He said, he did not like it, and that it absolutely made him ill. After a good deal of sparring, she took up the birch rod, and began to whip him with an uncommon degree of asperity. When the poor lad found that he must either drink the nauseous dish of ten or be flogged to death, he turned upon her in self-defence; showed her to the $2 \mathrm{~N}$ 


$$
\rightarrow
$$




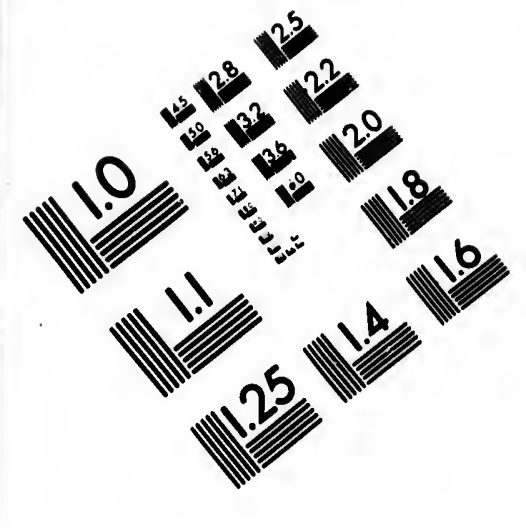

\section{IMAGE EVALUATION \\ TEST TARGET (MT-3)}
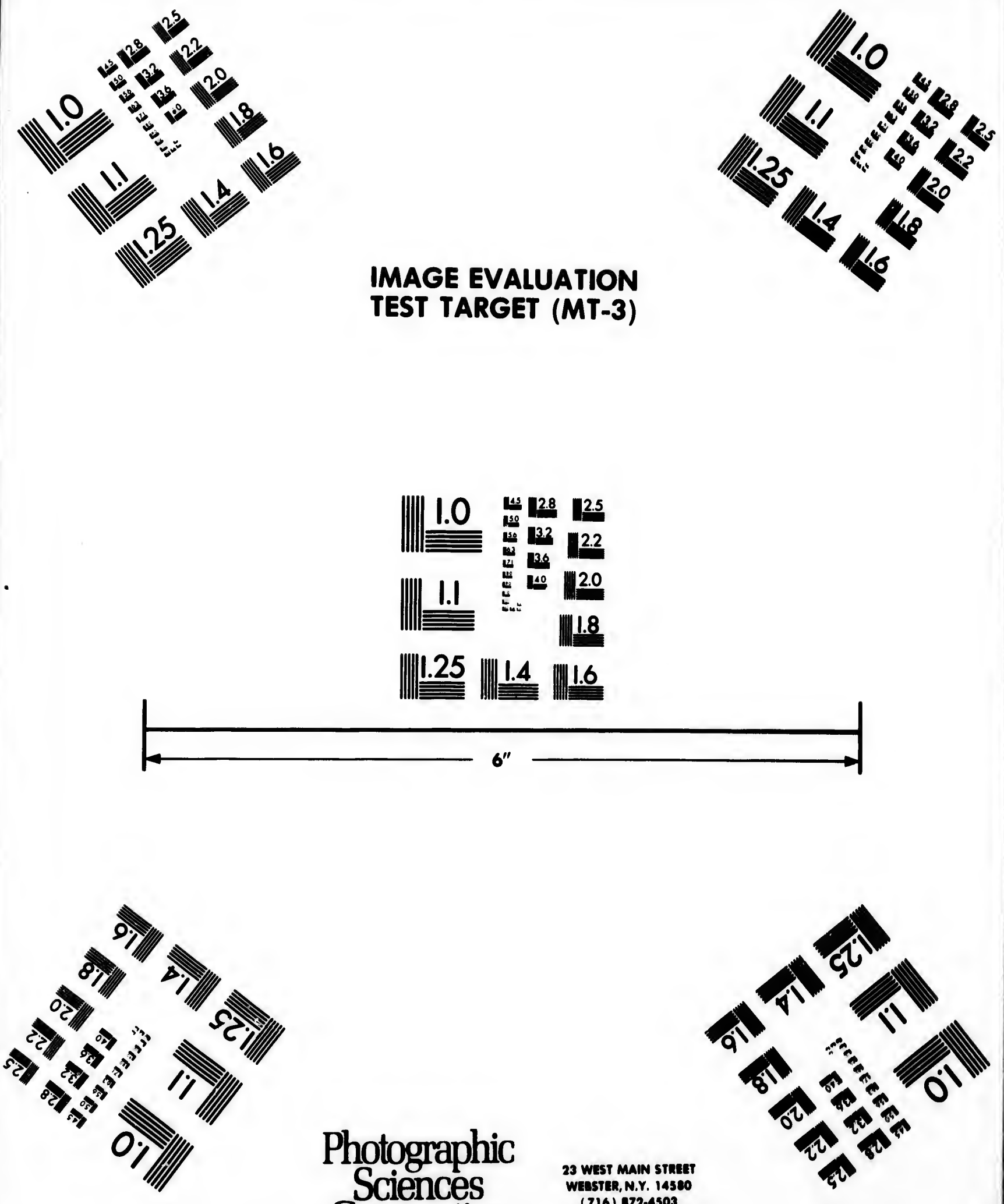

Photographic Corporation
23 WEST MAIN STREET WEASTER, N.Y. 14500

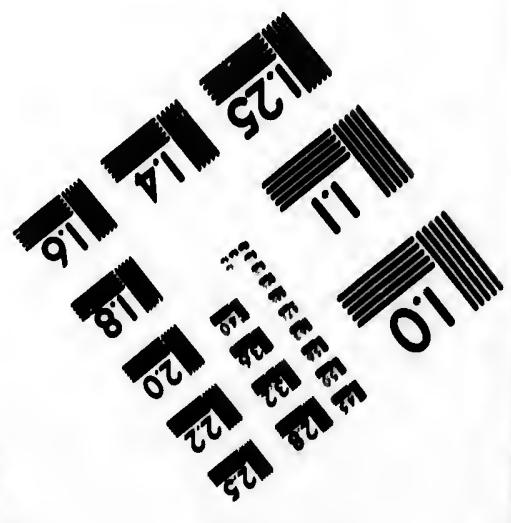


Founra outside of the nursery door, and never more allowed JouknEy. her to meddle with his affairs.

Since the independence, the population has increased from three to ten millions. A fine navy has been built; and every thing attended to that could ensure prosperity at home, and respect abroad.

The former wilds of North America bear ample testimony to the achievements of this enterprising people. Forests have been cleared away, swamps drained, eanals dug, and flourishing settlements established. From the shores of the Atlantic an immense column of knowledge has rolled into the interior. The Mississippi, the Ohio, the Missouri, and their tributary streans have been wonderfully benefited by it. It now seems as if it were advancing towards the stony mountains; and, probably, will not become stationary till it reaches the Paeific Ocean. This almost immeasurable territory affords a shelter and a home to mankind in general; Jew or Gentile, king's-man or republican, he meets with a friendly reception in the United States. His opinions, his persecutions, his errors, or mistakes, however they may have injured him in other countries, are dead, and of no avail on his arrival here. Provided he keeps the peace he is sure to be at rest.

Politicians of other countries imagine that intestine feuds will cause a division in this commonwealth; at present there certainly appears to be no reason for such 
a conjecture. Heaven forbid that it should happen. The world at large would suffer by it. For ages yet to come, may this great commonwealth continue to be the United States of North America.

The sun was now within a week or two of passing into the southern hemisphere, and the mornings and evenings were too cold to be comfortable. I embarked for the Embarks for island of Antigua, with the intention of calling at the Antigua. different islands in the Caribbean sea, on my way once more towards the wilds of Guiana.

We were thirty days in making Antigua, and thanked Providence for ordering us so long a passage. A tremendous gale of wind, approaching to a hurricane, had done mich damage in the West Indies. Had our passage been of ordinary length, we should inevitably liave been caught in the gale.

St. John's is the capital of Antigua. In better times it $\mathbf{s}_{\text {t. John's. }}$ may have had its gaieties and amusements. At present it appears sad and woe-begone. The houses, which are chiefly of wood, seem as if they have not had a coat of paint for many years; the streets are uneven and illpaved; and as the stranger wanders through them, he might faney that they would afford a congenial promenade to the man who is abciat to take his last leave of surrounding worldly misery, before he hangs himself. There had been no rain for some time, so that the parched and barren pastures near the town might, with great truth, be $2 \times 2$ 
Fovrth JOURNEY. called Rosinante's own. The mules feeding on them, put you in mind of Ovid's description of famine :-

" Dura cutis, per quain spectari viscera posscnt."

It is somewhat singular, that there is not a single river or brook in the whole island of Antigua. In this it differs from Tartary in the other world; which, according to old writers, has five rivers; viz. Acheron, Phlegeton, Cocytus, Styx, and Lethe.

In this island I found the Red-start, described in Wiison's " Ornithology of the United States." I wished to learn whether any of these birds remain the whole year in Antigua, and breed there; or whether they all leave it for the north when the sun comes out of the southern hemisphere; but, upon inquiry, I could get no information whatever.

Island of Gaudaloupe.

After passing a dull week here, I sailed for Guadaloupe, whose bold and cloud-capped moumtains have a grand appearance as you approach the island. Basseterre, the capital, is a neat town, with a handsome public walk in the middle of it, well shaded by a row of fine Tamarind trees on cach side. Behind the town, La Souffriere raises its high romantic summit; and, on a clear day, you may see the voleanic smot which issues from it.

Nearly micl-way, : vixt Guadaloupe and Dominica, you descry the Saintes. Though high, and bold, and rocky, they have still a diminutive appearance when coin- 
pared with their two gigantic neighbours. You just, see Marigalante to windward of them, some leagues off, about a yard high in the horizon.

Douninica is majestic in high and rugged mountains. Island of As you sail along it, you camnot help admiring its beautiDominica. ful coffee plantations, in places so abrupt and steep, that you would pronounee them almost inaccessible. Roseau, Roseau. the capital, is but a sinall town, and has nothing attractive except the well-known hospitality of the present harbourmaster, who is particularly attentive to strangers, and furnishes them with a world of informatior: concerning the West Indies. Roseau has seen better days; and you can trace good taste and judgment in the way in which the town has originally been laid out.

Some years ago it was visited by a succession of misfortunes, which smote it so severely, that it has never recovered its former appearance. A strong French fleet bombarded it; while a raging fire destroyed its finest buildings. Some time after, an overwhelming flood rolled down the gullies and fissures of the adjacent inountains, and carried all before it. Men, women, and children, houses, and property, were all swept away by this mighty torrent. The terrible scenc was said to beggar all description, and the loss was immense.

Dominica is fumous for a large species of frog, which the inhabitants keep in readiness to slaughter for the table. In the woods of this island, the large rhinoccros beetle 
is very common; it measures above six inches in length. In the same woods is found the beautiful humming-bird, the breast and throat of which are of a brilliant changing purple. I have searched for this bird in Brazil, and through the whole of the wilds from the Rio Branco, which is a branch of the Amazons, to the river Paumaron, but never could find it. I was told by a man in the Egyptian-hall, in Piccadilly, that this humming-bird is found in Mexico; but upon questioning him more about it, his information seemed to have been acquired by hearsay ; and so I concluded that it does not appear in Mexico. I suspect that it is never found out of the Antilles.

Martinico. After leaving Dominica, you soon reach the grand and magnificent island of Martinico. St. Pierre, its capital, is a fine town, and possesses every comfort. The inhabitants seem to pay considerable attention to the cultivation of the tropical fruits. A stream of water runs down the streets with great rapidity, producing a pleasing effect as you pass along.

Here I had an opportunity of examining a cuckoo, which had just been shot. It was exactly the same as the metallic cuckoo in Wilson's “ Ornithology." They told me it is a migratory bird in Martinico. It probably repairs to this island after its departure from the United States.

At a little distance from Martinico, the celebrated Diamond Rock rises in insulated majesty out of the sea. 
It was fortified during the last war with France, and bravely defended by an English captain.

Fountu

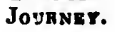

In a few hours from Martinico, you are at St. Lucie, St. Lucie. whose rough and towering mountains fill you with sublime ideas, as you approach its rocky shore. The town Castries is quite embayed. It was literally blown to Castries. pieces by the fatal hurricane, in which the unfortunate governor and his lady lost their lives. Its present forlorn and gloomy appearance, and the grass which is grown up in the streets, too plainly show that its hour of joy has passed away ; and that it is in mourning, as it were, with the rest of the British West Indies.

From St. Lucie, I proceeded to Barbadoes in quest of a conveyance to the island of Trinidad.

Near Bridge-town, the capital of Barbadoes, I saw the Barbaloes. metallic cuckoo, already alluded to.

Barbadoes is no longer the merry island it was when I. visited it some years ago :-

"Infelix habitum, temporis hujus habct."

There is an old song, to the tune of La Belle Catharine, which must evidently have been composed in brightel times:-

" Come let us dunce and sing, While Barbadoes bells do ring; Quashi scrapes the fiddle string, And Venus plays on the lute."

Quashi's fiddle was silent; and mute was the lute of 
Fourun Venus during my stay in Barbadoes. The difference Journer. betwixt the French and British islands was very striking. The first appeared happy and content; the second were filled with murmurs and compluints. The late proceedings in England, concerning slavery, and the insurrection in Demerara had evidently caused the gloom. The abo-

Slavery. lition of slavery is a question full of benevolence and fine feelings, difficulties and danger :-

"Tantum ne noceas, dum vis prodesse videto."

It requires consummate prudence, and a vast fund of true information, in order to draw just conclusions on this important subject. Pliaeton, by awkward driving, set the world on fire: "Sylva cum montibus ardent." Dedalus gave his son a pair of wings without considering the consequence; the boy flew out of all bounds, lost his wings, and tumbled into the sea:-

"Icarus, Icariis nomina fecit aquis."

When the old man saw what had happened, he damned his own handicraft in wing-making; " devovitque suas artes." Prudence is a cardinal virtue :-

" Omnia consultâ mente gerenda tegens."

Foresight is half the battle. "Hombre apercebido, medio combatido," says Don Quixote, or Sancho, I do not remember which. Had queen Bess weighed well in 
her own mind the probable consequences of this lamentable traffic, it is likely she would not have been owner of two vessels in sir John Hawkins's squadron, which committed the first robbery in negro flesh on the coast of Africa. As philanthropy is the very life and soul of this momentous question on slavery, which is certainly fraught with great difficulties and dunger, perhares it would be as well at present for the nation to turn its thoughts to poor ill-fited Ireland, where oppression, poverty, and rags make n heart-rending appeal to the feelings of the bencvolent.

But to proceed. There was another thing which added to the duhness of Barbadoes, and which seemed to have considerable effect in keeping awny strangers from the island. The legislature had passed a most extraordinary bill, by virtue of which every person who arrives at Barbadoes is obliged to pay two dollars, and two dollars more on his departure from it. It is called the alien bill; and every Barbadian who leaves or returns to the island, and every Englishman too, pays the tax!

Finding no vessel here for Trinidad, I embarked in a Embarksfor schooner for Demerara, landed there after being nearly stranded on a sand-bank, and proceeded without loss of time to the forests in the interior. It was the dry season, which renders a residence in the woods very delightful.

There are three species of Jacamar to be found on the different sand-hills and dry savannas of Demerara; but 
Poont: JounNEY.

The Jncamar. there is another much larger and far more benutiful to be seen when you arrive in that part of the country where there are rocks. The Jacamar has no affinity to the woodpecker or king's-fisher (notwithstanding what travellers affirm) either in its haunts or anatomy. The Jacnmar lives entirely on insects, but never goes in search of them. It sits patiently for hours together on the branch of a tree, and when the incautious insect appronches, it flies at it with the rnpidity of an arrow, seizes it, and generally returus to eat it on the branch which it had just quitted. It has not the least attempt at song, is very solitary, and so tame that you mny get within three or four yards of it before it takes flight. The males of all the different species which I have exnmined have white fenthers on the throat. I suspect that all the male Jacnmars hitherto discovered have this distinctive mark. I could learn nothing of its incubation. The Indians informed me that one species of Jacamar lays its eggs in the woodants' nests, which are so frequent in the trees of Guiana, and appear like huge black balls. I wish there had been proof positive of this; but the breeding time was over; and in the ants' nests which I examined, I could find no marks of birds having ever been in them. Early in January, the Jacamar is in fine plumage for the cabinet of the naturalist. The largest species measures ten inches and a half from the point of the beak to the end of the tail ; its name amongst the Indians is Una-waya- 
adoucati, that is, grandfather of the Jacamar. It is certainly a splendid bird; and in the brillianey and changeableness of its metallic colours, it yields to none of the Asiatic and African feathered tribe. The colours of the female are nearly as bright as those of the male, but she wants the white feathers on the throat. The large Jacamar is pretty common about two hundred miles up the river Demerara.

Here I had a fine opportunity once more of examining The threethe three-toed Sloth. He was in the house with me for a day or two. Had I taken a description of him as he lay sprawling on the floor, $I$ should have misled the world, and injured natural history. On the ground he nppeared really a bungled composition, and faulty at all points ; awkwardness and misery were clepicted on his countenance; and when I made him advance he sighed as though in pain. Perhaps it was, that by seeing him thus out of his element as it were, that the count de Buffon, in his history of the Sloth, nsks the question" why should not some animals be created for misery, since, in the human species, the greatest number of individuals are devoted to pain from the moment of their existence?" Werc the question put to me, I would answer, I cannot conceive that any of them are created for misery. That thousands live in misery there can be no doubt; but then, misery has overtaken them in their path through life, and wherever man has 2 o 2 

Jounkณy.

come up with them, I should suppose they have seldom escaped from experiencing a certain proportion of misery.

After fully sntisfying myself that it only lends the world into error to describe the Sloth while he is on the ground, or in any place except in a tree, I carried the one I had in my possession, to his native haunts. As soon as he came in contact with the branch of a tree, all went right with him. I could see as he climbed up into his own country, that he was on the right rond to happiness ; and felt persuaded more than ever, thant the world has hitherto erred in its conjectures concerning the Sloth, on account of naturalists not having given a description of him when he was in the only position in which he ought to have been described, namely, clinging to the branch of a tree.

As the appearance of this part of the country bears great resemblance to Cayenne, and is so near to it, I was in hopes to have found the Grande Gobe Mouche of Buffon, and the septicoloured ''angarn, both of which are common in Cayenne; but after many diligent searches, I did not succeed; nor could I learn from the Indians that they had ever seen those two species of birds in these parts. Here I procured the Gross-beak with a rich scarlet body, and black head and throat. Buffon mentions it as coming from America. I had been in quest of it for years, but could never see it, and concluded that it was not to be 
found in Demerara. This bird is of a greenish brown Founu before it accuires its rich plumnge.

Amongst the bare roots of the trees, alongside of this Procuren n part of the river, a red crab sometimes makes its ap- lurgespecinat pearmee, as you are passing up and clown. It is preyed upon by a large species of Owl, which I was fortunate enough to procure. Its hend, back, wings, and tuil, are of so clark a brown, as almost to appear black. The breast is of a somewhat lighter brown. The belly and thighs are of a dirty yellow white. The fenthers round the eyes nre of the same dark brown as the rest of the body ; and then comes a circle of white, which has much the appearmee of the rim of $n$ large pair of spectacles. I strongly suspect that the dirty yellow white of the belly and thighs has originally been pure white; and that it has come to its present colour by means of the bircl darting down upon its prey in the mud. But this is mere conjecture.

Here too, close to the river, I frequently saw the bird the Sunealled Sun-bird by the English colonists, and Tirana by the Spaniards, in the Oroonoque. It is very elegant ; and in its ontward nppeurance nppronches near to the heron tribe; still it does not live upon fisl. Flies and insects are its food; ancl it takes them just ns the heron takes fish, by approaching near, and then striking with its beak at its prey so quick, that it has no chance to escape. The benutiful mixture of grey, yellow, green, black, white, 

Fouray and ehestnut in the plumage of this bird, buftles any
Jovaney. attempt to give a description of the distribution of then, which would be satisfactory to the render.

There is something remarkable in the grent Tinnmou, which I suspect has hitherto escaped notice. It invuriably roosts in trees; but the feet are so very sunull in proportion to the body of this bulky bird, thint they cun be of 110 use to it in grasping the branch ; nnd, moreover. the hind toe is so short, that it does not touch the ground when the bird is walking. The baek part of the leg, just below the knee, is quite flat, and somewhnt concuve. On it are strong pointed scales, which are very rough, and catch your finger as you move it nlong from the knee to the toe. Now, by means of these sculew, nnd the particular flatness of that part of the log, the bird is enabled to sleep in safety upon the brunch of $\mathbf{n}$ tree.

At the close of day, the great Timamou gives $\boldsymbol{n}$ loud, monotonous, plaintive whistle, mod then immediately springs into the tree. By the light of the full moon, the vigilant and eautious muturnlist muy sec him sitting in the position alrendy described.

The small Tinamou has nothing that cun be culled a tail. It never lays more than one egg, which is of in chocolate colour. It makes no nest, but merely serutches n little hollow in the sand, genernlly nt the foot of a tree.

Here we have an instance of a bird, the size of a partridge, and of the same tribe, laying only one cgh, while 
the rest of the family, from the peahen to the quail, are known to lay a considerable number. The foot of this bird is very small in proportion, but the back part of the leg bears no resemblance to that of the larger Tinamou; hence one might conclude that it sleeps on the ground. Independent of the hollow trees, the Vampires have another hiding-place. They elear out the inside of the large ants' nests, and then take possession of the shell. I had gone about half a day down the river, to a part of the forest where the Wallaba trees were in great plenty. The seeds had ripened, and I was in hopes to have got the large searlet Ara which feeds on them. But, unfortunately, the time had passed away, and the seeds had fallen.

While ranging here in the forest, we stopped under an ant's nest; and, by the dirt below, conjectured that it had got new tenants. Thinking it no harm to dislodge them, " vi et armis," an Indian boy ascended the trec ; but before he reached the nest, ont flew above a dozen Vampires.

I have formerly remarked, that I wished to have it in The Vammy power to say, that $I$ had been sucked by the Vampire. pire. I gave them many an opportunity, but they always fought shy; and though they now sucked a young man of the Indian breed very severely, as he was sleeping in his hammock in the shed next to mine, they would have nothing to do with me. His great toe seemed to have 
Foorra all the attractions. I examined it minutely as he was Jounney. bathing it in the river at daybreak. The midnight surgeon had made a hole in it, almost of a triangular shape, and the blood was then running from it apace. His hammock was so defiled and stained with clotted blood, that he was obliged to beg an old black woman to wash it. As she was taking it down to the river side, she spread it out before me, and shook her head. I remarked, that I supposed her own toe was too old and tough to invite the Vampire-doctor to get his supper out of it ; and she answered, with a grin, that doctors generally preferred young people.

Nobody has yet been able to inform me how it is, that the Vampirc manages to draw such a large quantity of blood, generally from the toe, and the patient, all the time, remains in a profound sleep. I have never heard of an instance of a man waking under the operation. On the contrary, he continues in a sound sleep, and at the time of rising, his eyes first inform him, that there has been a thirsty thief on his toe.

Its teeth. The teeth of the Vampire are very sharp, and not unlike those of a rat. If it be that he inflicts the wound with his teeth, (and he seems to have no other instruments,) one would suppose that the acuteness of the pain would cause the person who is sucked, to awake. We are in darkness in this matter; and I know of no means by which one might be enabled to throw light upon it. 
It is to be hoped that some future wanderer through the wilds of Guiana, will be more fortunate than I have been, and cateh this nocturnal depredator in the fact. Thave once before mentioned that I killed a Vampire which measured thirty-two inches from wing to wing extended ; but others, which I have since examined, have generally been from twenty to twenty-six inches in dimension.

The large humming-bird, called by the Indians Kara- The Karabiniti, invariably builds its nest in the slender branches of the trees which hang over the rivers and creeks. In appearance, it is like brown tanned lenther, and without any particle of lining. The rim of the nest is doubled inwards, and I always conjectured that it had taken this shape, on account of the body of the bird pressing against it, while she was laying her eggs. But this was quite a wrong conjecture. Instinct has tanght the bird to give it this shape, in order that the eggs may be prevented from rolling out.

The trees on the river's bank are particularly exposed to violent gusts of wind, and while $I$ have been sitting in the canoe, and looking on, I have seen the slender branch of the tree which held the humming-bird's nest so violently shaken, that the bottom of the inside of the nest has appeared, and had there been nothing at the rim to stop the eggs, they must inevitably have been jerked out into the water. I suspeet the humining-bird never lays more than two eggs. I never found more than two in 
Fourti JOURNEY.

Monkies.

classes of Monkies. any of the many nests which have come in my way. The eggs were always white, without any spots on them.

Probably travellers have erred in asserting that the Monkies of Sontl America throw sticks and fruit at their pursuers. I have had fine opportunities of narrowly watching the different species of monkies which are found in the wilds, betwixt the Amazons and the Oroonoque. I entirely acquit them of acting on the offensive. When the Monkies are in the high trees over your head, the dead branches will now and then fall down upon you, having been broken off as the Monkies pass along them; but they are never hurled from their hands.

Monkies, commonly so ealled, both in the old and new continent, may be classed into three grand divisions; namely, the Ape, which has no tail whatever; the Baboon, which has only a short tail; and the Monkey, which has a long tail. There are no Apes, and no Baboons as yet discovered in the new world. Its Monkies may be very well, and very briefly ranged under two heads; namely, those with hairy and bushy tails ; and those whose tails are bare of hair underneath, about six inches from the extremity. Those with hairy and bushy tails climb just like the squirrel, and make no use of the tail to help them from branch to branch. Those which have the tail bare undernenth towards the end, find it of infinite advantage to them. in their ascent and descent. They apply it to the branch of the tree, as though it 
were a supple finger, and frequently swing by it from the branch like the pendulum of a clock. It answers all the purposes of a fifth hand to the monkey, as naturalists have already observed.

The large red Monkey of Demerara is not a Baboon, The large though it goes by that name, having a long pensile tail.* of Demerala. Nothing can sound more dreadful than its nocturnal howlings. While lying in your hammock in these gloomy and immeasurable wilds, you hear him howling at intervals, from eleven o'clock at night till daybreak. You would suppose that half the wild beasts of the forest were collecting for the work of carnage. Now, it is the tremendous roar of the Jaguar, as he springs on his prey : now, it changes to his terrible and deep-toned growlings, as he is pressed on all sides by superior force : and now, you hear his last dying moan, beneath a mortal wound.

Some naturalists have supposed that these awful sounds, which you would fancy are those of enraged and dying wild beasts, proceed from a number of the red Monkies howling in concert. One of them alone is capable of producing all these sounds; and the anatomists, on an inspection of his trachen, will be fully satisfied that this is the case. When you look at him, as he is sitting on the branch of a tree, you will see a lump in his throat,

* I believe prensile is a new-coined word. I have seen it, but do not remember where. 
Founsu the size of a large hen's egg. In dark and cloudy weather, and just before a squall of rain, this Monkey will often howl in the daytime; and if you advance cautiously, and get under the high and tufted tree where he is sitting, you may have a capital opportunity of witnessing his wonderful powers of producing these dreadful and discordant sounds.

Flesh of the His flesh is good food; but when skinned, his appearance is so like that of a young one of our own species, that a delieate stomach might possibly revolt at the idea of putting a knife and fork into it. However, I can affirm, from experience, that after a long and dreary march through these remote forests, the flesh of this Monkey is not to be sueezed at, when boiled in Cayemne pepper, or roasted on a stick over a good fire. A young one tastes not mulike kid, and the old ones have somewhat the flavour of he-goat.

I inentioned, in a former adventure, that I had hit upon an entirely new plan of mnking the skins of quadrupeds retain their exact form and feature. Intense application to the subject has sinee that period enabled me to shorten the process, and hit the character of an animal to a very great nicety, even to the preservation of the pouting lip, dimples, warts, and wrinkles on the face. I got a fine specimen of the howling Monkey; and took some pains with it, in order to show the immense difference that exists betwixt the features of this Monkey, and those of man. 
I also procured an animal which has caused not a little speculation and astonishunent. In my opinion, his thick coat of hair, and great length of tail, put his species out of all question; but then, his face and head cause the inspector to pause for a moment, before he ventures to pronounce his opinion of the classification. He was a large animal, and as $I$ was pressed for daylight, and moreover, felt no inclination to have the whole weight of his body upon my back, I contented mysclf with his head and shoulders, which I cut off; and have brought them with me to Lurope.* I lave since found, that I acted quite right in doing so, having had enough to answer fol' the head alone, without saying any thing of his hands and feet, and of his tail, which is an appendage, lord Kames asserts, loclongs to us.

The features of this animal are quite of the Grecian cast; and he has a placidity of countenance which shows that things went well with him when in life. Some gentlemen, of great skill and talent, on inspecting his head, were convinced that the whole scries of its features lias been clianged. Others again have lesitated, and betrayed doubts, not being able to make up their minds, whether it be possible that the brute features of the Monkey can

* My young friend, Mr. J. H. Foljambe, eldest son of Thomas Foljumbe, Esq. of Wakefield, has made a drawing of the head and shoulders of this amimal, (sce Frontispiece,) and it is certainly a most correct and striking likeness of the original. 
Foursu be ehnnged into the noble countenance of man.-
Jourszy. "Scinditur vulgus." One might argue at considerable length on this novel subject; and perhaps, after all, produce little more than a heap of prolix pedantry. "Vox et praeteren nilil."

Let us suppose for an instant, that it is a new species. Well ; "Una golondrina no hace vernuo ;" one swallow does not make summer, ns Sancho Panza says. Still, for all that, it would be well worth while going out to search for it ; and these times of Pasco-Peruvian enterprise are favourable to the undertaking. Perhaps, gentle readers, you would wish me to go in quest of another. I would beg leave respectfully to answer, that the way is dubious, long, and dreary ; and though, unfortunately, I cannot allege the excuse of " me pia conjux detinet," still I would fain crave a little repose. I have already been a long while errant :-

"Longa mihi exilia, et vastum maris cequor aravi, Ne mandate mihi, nam ego sum defessus agendo."

Should any body be induced to go, great and innumerable are the discoveries yet to be made in those remote wilds; and should he succeed in bringing home, even a head alone, with features as perfect as those of that which I have brought, fur from being envious of him, I should consider him a modern Alcides, fully entitled to register a thirteenth labour. Now if, on the other hand, we argue that this head in question has had all its original features 
destroyed, and a set of new ones given to it, by what means has this hitherto unheard of change been effected? Nobody in any of our museums las as yet been able to restore the natural features to stuffed animals; and he who has any doubts of this, let him take a living cat or dog and compare them with a stuffed cat or dog in any of the first-rate museums. A momentary glance of the eye would soon settle his doubts on this head.

If I have succeeded in effacing the features of a brute, and putting those of a man in their place, we might be entitled to say, that the sun of Proteus has risen to our museums :

"Unius hic faciem, facies transformat in onmes; Nunc homo, nunc tigris ; nunc equa nunc mulier."

If I have effected this, we can now give to one side of the skin of a man's face the appearance of eighty years, and to the other side that of blooming seventeen. We could make the forehend and eyes serene in youthful beauty, and shape the mouth and jaws to the features of a malicious old ape. Here is a new field opened to the adventurous and experimental naturalist : I have trodden it up and down till I am almost weary. To get at it myself I have groped through an alley, which may be styled, in the words of Ovid,-

“ Arduus, obliquus, caligine densus opaca."

I pray thee, gentle reader, let me out awhile. Time 
Fourin passes on apace; and I want to take thee to have a peep at the spots where mines are supposed to exist in Guiana. As the story of this singular hend has probably not been male out quite to thy satisfnetion, perhnps (I may say it nearly in corporal Trim's words) on some long and dismal winter's evening, but not now, I may tell thec more about it ; together with that of another head, which is equally striking.

It is conmonly reported, and I think there is no reason to doubt the fuct, that when Demernin and Essequibo were under the Dutch flag, there were mines of gold and silver opened near to the river Essequibo. The miners were not successful in their unclertaking, and it is generally conjectured, that their failure proceeded from inexperience.

Now, when you ascend the Essequibo, some hundred miles above the place where these mines are said to be found, you get into a high, rocky, and mountainous country. Here many of the mountains have a very barren aspect, producing only a few stinted slirubs, and here and there a tuft of conrse grass. I could not learn that they have ever been explored, and at this day their mineralogy is totally unknown to us. The Indians are so thinly scattered in this part of the comtry, that there would be no impropriety in calling it uninhabited :-

"Apparent rari errantes in gurgite vasto."

It remains to be yet learnt, whether tis portion of 
Guiana be worth looking ufter, with respect to its supposed mines. The mining speenlations at present are flowing down another channcl. The ringe in Englund for working the mines of other states has now risen to such a pitch, thint it would require a considerable degree of caution in a mere wanderer of the woods, in stepping forward, to sny any thing that might tend to raise or depress the spirits of the speculators.

A cuestion or two, however, might be asked. When the revolted colonies shull have repaired in some measure the ravages of war, and settled their own political economy upon a firm foundation, will they quietly submit to see forcigners earrying away those trensures which are absolutely part of their own soil, and which necessity (necessity has no law) forced them to barter away in their hour of neel: Now, if it should so lappen that the masters of the comntry begin to repent of their bargain, and become envious of the riches which foreigners carry off, many a teasing luw might be made, and many a vexatious enaction might be put in force, that would, in all probability, bring the speculitors into trouble and disuppointment.

Besides this consideration, there is mother circmmstance which ought not to be overlooked. I allude to the chunge of masters nearly throughout the whole of Annerica. It is a currous subject for the European philosopher to moralize upon, and for the politician to 2 a 
Founth Jovanky. exninine. The more they consider it, the more they will be nstonished. If we may judge by what has alrendy tuken pluce, we are entitled to predict, that in a very few years more, no European bnuner will be seen to flont in any purt of the new world. Let us take n cursory vicw of it.

England some yenrs ago possessed n large portion of the present United States. Frnnce hnd Louisiana; Spain held the Floridas, Mexieo, Darien, Terrn Firma, Buenos Ayres, Puraguay, Chili, Peru, and Californin ; and Portugal ruled the whole of Brnzil. All these immense regions are now independent states. England, to be sure, still has Canada, Nova Scotia, and a few crecks on the const of Labraclor; also a small settlement in Honduras, and the wilds of Demerara and Essecpuibo ; and these are nll. France has not a foot of ground, exeept the forests of Cayenue. Portugal lins lost every province; Spnin is blockaded in nearly her lust citadel ; and the Duteh flag is only seen in Surinam. Nothing more now remains to Europe of this immense continent, where, but a very few years ago, she reigned triumpliant.

With regard to the West India Islands, they may be considered as the mere outposts of this Mammoth domain. St. Domingo has already shaken oft her old masters, and become a star of observation to the rest of the sable brethren. The anti-slavery associations of England, fuil of benevolence and activity, have opened a tremendous 
battery upon the last remnining forts, which the lords of the old continent still hold in the new world; and, in all probubility, will not eense firing till they shall have caused the last flag to be struck, of Europe's late mighty empire in the trunsathntic regions. It camnot well be doubted, but that the sable hordes in the West Indies will like to follow good exnmple, whenever they shall have it in their power to do so.

Now, with St. Domingo as mn example before them, how long will it be before they try to rnise themselves into independent stntes: And if they should suceed in crushing us in these our last remaining tenements, I would bet ten to one thint none of the new govermunents will put on mourning for our departure out of the new world. We must well remember, that our own government was taxed with injustice nud oppression by the United Stntes during their grent struggle; and the British press for years past lus, and is still tecming with every kind of nbuse und unbecoming satire against Spuin and Portugal for their conduct towards the now revolted colonies.

Frnnee also comes in for her share of oblocpuy. Now, this being the ense, will not America nt linge wish most devoutly for the day to come when Europe shall have no more dominion over her? Will she not say to us, our new forms of govermment are very different from your old ones. We will trade with you, but we shall nlways be 2 \& 2 
very suspicious of you as long ns you retuin punsersion of the West Indies, which are, us we miny nuy, clone to our door-steads. You must be very eautious loow you interfere with our polities; for, if we find you meddling with them, and by that means canse us to come to longgel-. heads, we shall be obliged to send you bucks to yenur own homes, three or four thousand miles nerons the Atluntic ; and then, with that great ditch betwixt us, Wo muly hope we shall be good friends. He who consts his cye onl the East Indies, will there sce quite a ditferent stute of thingrs.

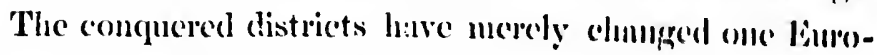
pean master for another; and I beliere tluere is no instance of any portion of the lanst Inelien therwing oft the yoke of the Europeans and estnblishing 1 goreremunent of their own.

Ye who are rersed in polities, and study the rise and fall of empires, and know what is good fol civilizenl mum, and what is bad for him, or in othere words whint will make him happy and what will make him minemble-tell us how comes it that burope has lost mlunest lier lust acre in the boundless expanse of territeny which slac not lately posscessed in the west, and still contrives to hold her vast property in the exterusive rexions of the east?

But whither an 1 going? I find myself onI || IICW mud dangerons path. Pardon, gentle render', this sudden deviation Methinks I lean thee snying to mer,- 
" 'Trmite quo tendis, majoraque viribus andes."

I grant that I have erred, but $I$ will do so no more. In Jotrney. general 1 avoid polities; they are too heavy for me, and I. an aware that they have caused the fall of many a strong and able man; they require the shoulders of Atlas to support their weight.

When 1 was in the rocky mountains of Maconshia, in Cocks of the the month of June, 1812, I saw four young Cocks of the Rock. Rock in an Indian's hut; they latd been taken out of the nest that week. They were of a uniform clirty brown colour, and by the position of the young feathers upon the head, you might see thitt there would be a crest there when the bird anriced at maturity. By seeing young ones in the month of Junc; I immediately eoncluded that the old Cock of the Rock wonld be in fine plumage fiom the end of November to the begimning of May; and that the naturalist, who was in quest of specimens for his musemu, onght to arrange his plans in such a mamer as to be able to get into Macoushia during these months. However, I find now, thitt no exact period can be fixed; for, in December, 18:2, an Indian, in the river 1)emeram, gave me a young Cock of the Rock not a month old, and it hatd just been brought from the Macoushi country. By having a young specimen at this time of the year, it puts it out of one's power to saly at what precise time the old birds are in full plumage. I took it on board a ship with me for England, but it was so very susecptible of cold 
Fovrta JOUKNEY.

Indian rubber.

An Indiun trick. that it shivered and died, three days after we had passed Antigua.

If ever there should be a great demand for large supplies of gum elastic, commonly called Indian rubber, it may be procured in abundance far away in the wilds of Demerara and Essequibo

Some years ago, when I was in the Macoushi country, there was a capital trick played upon me about Indian rubber. It is almost too good to be left ont of these wanderings, and it shows that the wild and medueated Indian is not without abilities. Weary and sick, and feeble through loss of blood, I arrived at some Indian huts, which were abont two hours distant from the place where the gum elastic trees grew. After a day and a night's rest I went to them, and with my own hands made a fine ball of pure Indian rubber; it hardened immediately as it became exposed to the air, and its elasticity was almost incredible.

While procuring it, exposure to the rain, which fell in torrents, brouglit on a return of inflammation in the stomach, and I was obliged to have recourse again to the lancet, and to use it with an unsparing hand. I wanted another ball, hut was not in a state the next morning to proceed to the trees. A fine interesting young Indian, observing my eagerness to have it, tendered his serviees, and asked two handsfill of fish-hooks for his trouble.

Off he went, and to my great surprise returned in a 
very short time. Bearing in mind the trouble and time it had cost me to make a ball, I could account for this Indian's expedition, in no other way, except, that being an inhabitant of the forest, he knew how to go about his work in a much shorter way than I did. His ball, to be sure, had very little elasticity in it. I tried it repeatedly, but it never rebounded a yard high. The young Indian watched me with great gravity, and when I made him understand that $I$ expected the ball would dance better, he called amother Indian, who knew a little English, to assure me that I might be quite easy on that score. The young rogue, in order to render me a complete dupe, brought the new moon to his aid. He gave me to understand that the ball was like the little moon, which he pointed to, and by the time it grew big and old, the ball would bounce beautifully. This satisfied me, and I gave him the fish-hooks, which he received without the least change of countenance.

I bounced the ball repeatedly for two months after, but I found that it still remained in its infancy. At last I suspected that the savage (to use a vulgar phrase) had come Yorkshire over me; and so I determined to find out how he had managed to take me in. I cut the ball in two, and then saw what a taught trick he had played me. It seems he had chewed some leaves into a lump, the size of a walnut, and then dipped them in the liquid gunelastic. It immediately received a coat about as thick 
Focrti Jovixey.

as a sixpence. He then had rolled some more leaves round it, and gave it another coat. He scems to have continued this proeess, till he made the ball considerably larger than the one $I$ had procured; and in order to put his rognery out of all chance of detection, he made the last and outer coat thicker than a dollar. This Indian wonld, no doubt, have thriven well in some of our great towns.

Returns home to England.

Finding that the rainy season was coming on, I left the wilds of Demerara and Essequibo with regret, towards the close of December, 1824; and reached once more the shores of England, after a long and unpleasant passage. of thy attention to the instructions which are to be found at the end of this book. Twenty years have now rolled away, since I first began to examine the specimens of zoology in our museums. $A$ s the system of preparation is founded in error, nothing but deformity, distortion, and disproportion, will be the result of the best intentions, and utmost exertions of the workman. Canova's cducation, taste, and genius enabled him to present to the workd, statues so correct and beantiful, that they are worthy of universal admiration. Had a common stonecutter tried his hand upon the block, out of which these statues were seulptured, what a lamentable want of symmetry and fine countenance there would have been. 
Now when we reflect that the preserved specimens in our museums, and private collections, are always done upon a wrong principle, and generally by low and illiterate people, whose daily bread depends upon the shortness of time in which they can get through their work; and whose opposition to the truc way of preparing specimens, can only be surpassed by their obstinacy in adhering to the old method; can we any longer wonder at their want of success? or hope to see a single specimen produced that will be worth looking at? With this I conclude, hoping that thou hast received some information, and occasionally had a smile upon thy countenance, while persusing these "Wanderings ;" and begging, at the same time, to add, that,

Well I know thy penetration,

Many a stain and blot will see,

In the languid long narration, Of my sylvan errantry.

For the pen, too oft was weary,

In the wandering writer's hand, As he roved through deep and dreary

Forests, in a distant land.

Show thy mercy, gentle render,

Let him not entreat in vain;

It will be his strength's best feeder,

Should he ever go again. 
306

Foonst

JounNEx.
WANDERINGS IN SOUTH AMERICA.

And who knows, how soon complaining, Of a cold and wifeless home,

He may leave it, and again in

Equatorial regions roam.

c. W. 
ov

\section{PRESERVING BIRDS}

FOR

\section{CABINETS OF NATURAL HISTORY.}

Were you to pay as much attention to birds, as the Preservina sculptor does to the human frame, you would immediately Birps. see, on entering a museum, that the specimens are not well done.

This remark will not be thought severe, when you reflect that,-that which once was a bird, has probably been stretched, stuffed, stiffened, and wired by the hand of a common clown. Consider, likewise, low the plumage must have been disordered, by too much stretching or drying, and perliaps sullied, or at least deranged, by the pressure of a coarse and heavy hand,-plumage which, ere life had fled from within it, was accustomed to be touched by nothing rougher than the dew of heaven, and the pure and gentle breatl of air.

In dissecting, three things are necessary to ensure Dissecting. success ; viz. a penknife, a laand not coarse or clumsy, and practice. The first will furnish you with the means; the second will enable you to dissect; and the third 2 R 2 
Pazarning cause you to dissect well. These may be called the mere mechanical requisites.

Stuffing. In stufting, you require cotton, a needle and thread, a little stick, the size of a common knitting-needle, glass eyes, a solution of corrosive sublimate, and any kind of a common temporary box to hold the specimen. These also may go uncler the same denomination as the former. But, if you wish to excel in the art, if you wish to be in ornithology, what Angelo was in sculpture, you must apply to profound study, and your own genius to assist you. And these may be ealled the scientific repuisites.

Requisite to huse thorough knowledge of Ornithio logical Anatomy.

You must have a complete knowledge of ornithologieal anatomy. You must pay close attention to the form and attitude of the bird, and linow exactly the proportion each curve, or extension, or contraction, or expansion of any particular part bears to the rest of the body. In a word, you must possess Promethean boldness, and bring down fire, and animation as it were, into your preserved specimen.

Examine Repair to the haunts of birds, on plains and mountains, the economy of the orders forests, swamps, and lakes, and give up your time to of bircls. examine the economy of the different orders of birds.

Then you will place your eagle, in attitude commanding, the same as Nelson stood in, in the day of battle, on the Victory's quarter-deck. Your pie will seem crafty, and just ready to take flight, as though fearful of being surprised in some mischievous plunder. Your 
sparrow will retain its wonted pertness, by meims of Prearaviwa placing his tail a little elemeded, and giving a moderate BiRD. areh to the neck. Your vu.urre will show his sluggish habits, by having his body nearly parallel to the enrtlı; his wings somewhat drooping, and their extremities under the tail, instead of above it,-expressive of ignoble indolence.

Your dove will be in artless, fearless innocence; looking mildly at you, with its neck, not too much, stretched, as if uneasy in its situation; or drawn too close into the shoulders, like one wishing to avoid a discovery; but in moderate, perpendicular length, supporting the head horizontally, which will set off the breast to the best advantage. And the breast ought to be conspicuous, and have this attention paid to it; for when a young lady is sweet and gentle in her manners; kind and affinble to those around her; when her eyes stand in tears of pity for the woes of others, and she puts a small portion of what Providence has blessed her with into the hand of imploring poverty and hunger, then we say, she has the breast of a turtle dove.

You will observe how beautifully the feathers of a bird The fenare arranged ; one falling over the other in nicest order; and that, where this chamming hamony is interrupted, the defect, though not noticed by an ordinary spectator, will appear immediately to the eye of a naturalist. Thus, a bird not wounded, and in perfeet feather, must be 
Pumoziviso procured if possible ; for the loss of feathers can seldom Bross. be made good; and where the deficiency is great, all the skill of the artist will avail him little in his attempt to conceal the defect; because, in order to hide it, he must contract the skin, bring down the upper feathers, and shove in the lower ones, which would throw all the surrounding parts into contorsion.

You will also observe that the whole of the skin does not produce feathers, and that it is very tender where the feathers do not grow. The bare parts are admirably formed for expansion about the throat and stomaeh ; and they fit into the different eavities of the body at the wings, shoulders, rump, and thighs, with wonderful exactness; so that, in stufting the bird, if you make an even rotund surface of the skin, where these cavities existed, in lieu of re-forming them, all symmetry, order, and proportion, are lost for ever.

You must lay it down as an absolute rule, thant the bird is to be entirely skimed, utherwise you can never suceeed in forming a true and pleasing specimen.

You will allow this to be just, after reflecting a moment on the nature of the fleshy parts and tendons, which are often left in : 1st, they require to be wellsensoned with aromatic spiccs; 2dly, they must be put into the oven to dry; 3dly, the lient of the fire and the natural tendeney all cured flesh has to shrink, and become hard, render the specimen withered, distorted, and too small; 
4thly, the inside then becomes like a latm,

any other Passenvene dried ment. Ere long, the insects claim it, their $0, a$; Bass. the feathers begin to drop off, and you have the hideous spectacle of death in ragged plumage.

Wire is of no manner of use, but, on the contrary, a great nuisance; for where it is introduced, a disagreeable stiffness and derangement of symmetry follow.

The head and neck can be placed in any attitude, the body supported, the wings closed, extended or elevated, the tail depressed, raised or expanded, the thighs set horizontal or oblique, without any aid from wire. Cotton will effect all this.

A very small proportion of the scull bone, say, from the forepart of the cyes to the bill, is to be left in; though even this is not absolutely necessary. Part of the wing-bones, the jaw-bones, and half of the thigh-bones, remain. Every thing else, flesh, fat, eyes, bones, brains, and tendons, are all to be taken away.

While dissecting, it will be of use to keep in mind, - General That, in taking off the skin from the body, by means directions. of your fingers and little knife, you must try to shove it, in lieu of pulling it, lest you stretch it.

That, you must press as lightly as possible on the bird, and every now and then take a view of it, to see that the feathers, \&c. are all right.

That, when you come to the head, you must take care that the body of the skin rests on your knee; for if you 
Panaknviva allow it to dungle from your hand, its own weight will Bimss. stretch it too much.

Thut, throughout the whole operntion, as fast as you detach the skin from the body, you must put cotton immedintely betwixt the borly and it; and this will effectually prevent uny fint, blood, or moisture from coming in contnet with the plimnge. Here it may be observed that, on the belly you find an inner skin, which keeps the bowels in their place. By a nice operation with the knife, you can ent through the outer skin, and leave the inner slin whole. Attention to this will render your work very clem ; so that, with a little care in other purts, you may skin a bird without even soiling your finger ends.

As you can seldom get n bird without shooting it, a line or two on this hend will be necessary. If the bird be still alive, press it hard with your finger and thumb, just behind the wings, and it will soon expire. Carry it by the legs, and then the body being reversed, the blood cannot escape down the plumage through the shot holes. As blood will often have issued out before you have laid hold of the bird, find out the shot holes, by dividing the fenthers with your fingers, and blowing on them, and then, with your penknife, or the leaf of a tree, carefully remove the clotted blood, and put a little cotton on the liole. If, after all, the plumnge has not escaped the marks of blood; or if it has imbibed slime from the ground, wash 
the part in wuter, without soap, and keep g(-ntly agitating l'ursknviso the ferithers, with your fingers, till they nre quite diry. Were Bindw. you to wash them, und leave them to dry by themselves, they would liave a very mean and shrivelled appearunce.

In the act of skinning a bird, you snust either have it Act of shinupon a table, or upon your knee. Probubly, you will bird. prefer your knee; becuuse, when you cross one knee over the other, and linve the bird upon the uppermost, you can raise it to your "ye, or lower it, at plensure, by menus of the foot on the ground, and then your kne will ulwnys move in unison with your body, by which much stoopis will be aroided nud lassitude prevented.

With these precentionury hints in mind, we $w i$ : proceed to dissect a bird. Suppose we talie The little birds will thank us, with a song for his death, for he has oppressed them sorely; and in size he is just the thing. His skin is also pretty tough, and the feathers udlice to it.

We will put close by us a little bottle of the solution of corrosive sublimate in alcohol; also a stick like a common knitting needle, and a handful or two of eotton. Now fill the month and nostrils of the bird with cotton, nud place it upon your knec on its back, with its licad pointing to your left shoulder. 'Take hold of the knife with your two first fingers and thumb, the edge upwards. You must not kecp the point of the knife perpendicular to the body of the bird; beciuse, were you to hold it so, you 
Preservisg would eut the inner skin of the helly, nud thus let the BIRUS. bowels ont. To avoid this, let your knife be purnllel to the body, and then you will divide the outer skin with great ease.

Begin on the belly below the brenst-lome, and cut down the middle, quite to the vent. 'I'his done, put the bird in any convenient position, and Nepurnte the skin from the body, till you get at the middlle joint of the thigh. Cut it through, and do wothing more there at present, execpt introducing cotton all the why on that side, from the vent to the breast-bone. Do exuctly the same on the opposite side.

Now place the bird perpendieular, its brenst resting on your knee, with its back towirds you. Sopurnte the skin from the body on each side at the vent, und never mind at present the part from the vent to the root of the tail. Bend the tail gently down to the buck, und while your finger and thumb are keeping down the detuehed purts of the skin on each side of the vent, cut quite nerons, and deep, till you see the back-bone, near the oil glumd nt the root of the tail. Sever the back-bone ut the joint, and then you have all the root of the tnil, together with the oil-gland, dissected from the bolly. Apply plenty of cotton.

After this, seize the end of the bnck-bone with your finger and thumb: and now you cmu leold up the bird clear of your knee, and turn it round and round, as 
occasion requires. While you are holding it thus, con- Preservisa trive, with the help of your other hand and knife, by Birds. cutting and shoving, to get the skin pushed up till you come to where the wing joins on to the body.

Forget not to apply cotton; cut this joint through ; do the same at the other wing, add cotton, and gently push the skin over the head; cut out the roots of the ears, which lic very deep in the liead, and continue skimuing till you reach the middle of the eye; cut the wintitating membrane quite through, otherwise you would tear tre orbit of the eye; and after this, nothing difficult intervenes to prevent your arriving at the root of the bill.

When this is effected, ent away the body, leaving a little bit of skull, just as much as will reach to the forepart of the eye; clean well the jaw-bones, fasten a little cotton at the end of your stick, dip it into the solution, and touch the skull and corresponding part of the skin, as you camnot well get to these places afterwards. From the time of pushing the skin over the head you are supposed to have had the bird resting upon your knee; kecp it there still, and with great caution and tenderness return the head through the inverted skin, and when you see the beak appearing, pull it very gently till the head comes out umruftled and unstained.

You may now take the cotton out of the mouth; cut away all the remaining flesh at the palate, and whatever may have remained at the under jaw. 
Presunving

Here is now before you the skin, without loss of any BiRDE. fenthers, and all the flesh, fat, and uncleaned bones out of it, except the middle joint of the wings, one bone of the thighs, and the fleshy root of the tail. The extreme point of the wing is very small, and has no flesh on it, comparatively speaking, so that it requires no attention, except tonching it with the solution from the outside. Take all the flesh from the remaining joint of the wing, and tic a thread about four inches long to the end of it ; touch all with the solution, and put the wing bone back into its place. In baring this bone you must by no means pull the skin; you would tear it to pieces beyond all doubt, for the ends of the long feathers are attached to the bone itself; you must push off the skin with your thumb-nail and forefinger. Now skin the thigh quite to the knee; cut away all flesh and tendons, and leave the bone; form an artifieial thigh round it with cotton; apply the solution, and draw back the skin over the artificial thigh : the same to the other thigh.

Lastly, proceed to the tail; talie out the inside of the oil-gland, remove all the remaining flesh from the root, till you see the ends of the tail feathers; give it the solution, and replace it. Now take out all the cotton which you have been putting into the body from time to time to preserve the feathers from grease and stains. Place the bird upon your knee on its back; tie together the twe threads which you had fastened to the end of the 
wing joints, leaving exactly the same space betwixt them Preservive as your knowledge in anatomy informs you existed there Birds. when the bird was entire; hold the skin open with your finger and thumb, and apply the solution to every part of the inside. Neglect the hiad and neek at present ; they are to receive it afterwards.

Fill the body moderately with cotton, lest the feathers on the belly should be injured whilst you are about the following operation. You must recollect that half of the thigh, or in other words, one joint of the thigh bone, has been cut away. Now, as this bone never moved perpendicular to the body, but on the contrary in an oblique direction, of course, as soon as it is cut off, the renaining part of the thigh and leg, having nothing now to support them obliquely, must naturally fall to their perpendicular. Hence the reason why the legs appear considerably too long. To correct this, take your needle and thread, fasten the end round the bone inside, and then push the needle through the skin just opposite to it. Look on the outside, and after finding the needle amongst the feathers, tack "1) the thigh under the wing with several strong stitches. This will shorten the thigh, and rencler it quite capable of supporting the weight of the body without the help of wire. This done, take out every bit of cotton, except the artificial thighs, and adjust the wing bones (which are connected by the thread) in the most even manner possible, so that one joint does not 
Presenvisa appear to lie lower than the other; for unless they are Buns.

quite equal, the wings themselves will be unequa, when you come to put them in their proper attitude. Here then rests the shell of the poor hawk, ready to receive, from your skill and judgment, the size, the shape, the features and expression it had, ere deatl, and your dissecting hand, brought it to its present still and formless state. The cold hand of death stamps deep its maik upon the prostrate victim. When the heart ecases to beat, and the blood no longer courses through the veins, the features collapse, and the whole frame seems to shrink within itsclf. If then you have formed your idea of the real appearunce of the bird from a dend specimen, you will be in error. With this in mind, and at the same time forming your specinen a tritle larger than life, to make up for what it will lose in drying, you will reproduce a bird that will please you.

It is now time to introduce the cotton for an urtificial bodly, by metuss of the little stick like a knitting needle; and without any other aid or substance than that of this little stick and cotton, your own genius must produce those swellings and eavities, that just proportion, that elegance and harmony of the whole, so much admired in animated nature, so little attended to in preserved speeimens. After you have introduced the cotton, sew up the orifice you originally made in the belly, beginning ut the vent. And from time to time, till you amive at the last 
stitel, keep adding a little cotton, in order that there may Preservivo be no deficiency there. Lastly, dip your stick into the BIRDS. solution, and put it down the throat three or four times, in order that every part may receive it.

When the head and neck are filled with cotton quite to your liking, close the bill as in nature. A little bit of bees' wax, at the point of it, will keep the mandibles in their proper place. A needle nust be stuck inte the lower mandible perpendicularly. You will shortly see the use of it. Bring also the feet together by a pin, and then run a thread through the knees, by which you may draw them to each other, as near as you judge proper. Nothing now remains to be added but the eyes. Witl your little stick make a hollow in the cotton within the orbit, and introduce the glass eyes tlurough the orbit. Adjust the orbit to them, as in nature, and that require no other fastener.

Your close inspection of the eyes of animals, will already have informed you, that the orbit is capable of receiving a much larger body than that part of the eye which appears within it when in life. So that, were you to proportion your eye to the size the orbit is capable of receiving, it would be far too large. Inattention to this, has eaused the eyes of every specimen, in the best cabinets of natural history, to be out of all proportion. To prevent this, eontract the orbit, by means of a very small delicate needle and thread, at that part of it farthest from 
Praserving the beak. This may be done with such nicety, that the BiRDs. stitch cammot be observed ; and thus you have the artificial eye in true proportion.

After this, tonch the bill, orbits, feet, and former oilgland at the root of the tail, with the solution, and then you have given to the hawk every thing necessary, exeept attitude, and a proper degree of elasticity, two qualities very essential.

Procure any common ordinary box, fill one end of it, about three-fourths up to the top, with cotton, forming a sloping plane. Make a moderate hollow in it to receive the bird. Now take the hawk in your hands, and, after putting the wings in order, place it in the cotton, with its legs in a sitting posture. The head will fall down. Never mind. Get a cork, and run three pins into the end, just like a three-legged stool. Place it under the bird's bill, and run the needle, which you formerly fixed there, into the head of the cork. This will support the bird's hend admirably. If you wish to lengthen the neck, raise the cork, by putting more cotton under it. If the head is to be brought forward, bring the cork nearer to the end of the box. If it requires to be set backwards on the shoulders, move back the cork.

As in drying, the back part of the neck will shrink more than the forepart, and thus throw the beak higher than you wish it to be, putting you in mind of a stargazing horse, prevent this fault, by tying a thread to the 
beak, and fastening it to the end of the box with a pin or Presenving needle. If you choose to elevate the wings, do so, and BIRDS. support them with cotton; and should you wish to have them particularly high, apply a little stick under each wing, and fasten the end of them to the side of the box with a little bees' wax.

If you would have the tail expanded, reverse the order of the feathers, beginning from the two middle ones. When dry, replace them in their true order, and the tail will preserve for ever the expansion you have given it. Is the crest to be erect? move the feathers in a contrary direction to that in which they lie, for a day or two, and it will never fall down after.

Place the box any where in your room, out of the influence of the sum, wind, and fire ; for the specimen must dry very slowly, if you wish to reproduce every feature. On this account, the solution of corrosive sublimate is uncommonly serviceable; for at the same time that it totally prevents putrefaction, it renders the skin moist and flexible for many days. While the bircl is drying, take it out, and replace it in its position once every day. Then, if you see that any part begins to shrink into clisproportion, you can easily remedy it.

The small covert feathers of the wings are apt to rise a little, because the skin will come in contact with the bone which remains in the wing. Pull gently the part that rises, with your finger and thumb, for a day or two. 
Parsenviva Press the feathers down. The skin will adhere no more Binds. to the bone, and they will cense to rise.

Every now and then tonch and retouch all the different parts of the features, in order to render them distinet and visible, correcting at the same time any harslness, or unnatural risings, or sinkings, flatness, or rotundity. This is putting the last finishing hand to it.

In three or four days the feet lose their natural elasticity, and the knees begin to stiffen. When you observe this, it is time to give the legs any angle you wish, and arrange the toes for a stancling position, or curve them to your finger. If you wish to set the bird on a branch, bore a little hole under each foot, a little way up the leg; and having fixed two proportionnl spikes on the branch, you can, in a moment, transfer the bird from your finger to it, and from it to your finger, at pleasure.

When the bird is quite dry, pull the thread out of the knees, take away the needle, \&c., from under the bill, and all is done. In lien of being stiff with wires, the cotton will have given a considerable elasticity to every part of your bird ; so that, when perching on your finger, if you press it down with the other hand, it will rise again. You need not fear that your hawk will alter, or its colours fade. The alcohol has introduced the sublimate into every part and pore of the skin, quite to the roots of the feathers. Its use is twofold. 1st. It has totally prevented all tendency to putrefaction; and thus a sound 

skin has attached itself to the roots of the feathers. You Pagkrnuisac may take hold of a single one, and from it suspend five times the weight of the bird. You may jerk it; it will still adhere to the skin, and, after repeated trials, often break short. 2dly. As no part of the skin has eseaped receiving particles of sublimate contained in the alcohol, there is not a spot exposed to the depredation of insects ; for they will never venture to attack any substance which has received corrosive sublimate.

You are aware that corrosive sublimate is the most fatal poison to insects that is known. It is antiputreseent ; so is alcohol; and they are both colourless, of course they camnot leave a stain behind them. The spirit penetrates the pores of the skin with wonderful velocity, deposits invisible particles of the sublimate, and llies off. The sublimate will not injure the skin, and nothing ean detach it from the parts where the alcohol has left it.*

Furs of animals, immersed in this solution, will retain their pristine brightness and durability in any climate.

Take the finest curled feather from a lady's head, dip it in the solution, and shake it gently till it be dry; you will find, that the spirit will fly off in a few minutes, not a curl

* All the fenthers require to be touched with the solution, in order that they may be preserved from the depredation of the moth. The surest way of proceeding is, to immerse the birl in the solution of corrosire sublimate, and then dry it before you begin to disseet it. 

l'anesnuwa in the feather will be injured, and the sublimate will pre-
Braps. serve it from the depredation of the insect.

Perhaps it may be satisfactory to add here, thut, some years ago, I did a bird upon this plun in Demerara. It remained there two years. It was then conveyed to England, where it stuid five months, and returned to Demerara. After being four years more there, it was conveyed back again through the West Indies to England, where it has now been near five years, unfuded and unchanged.

On reflecting that this bird has been twice in the temperate and torrid zone, and remained some years in the hot and humid climate of Demerara, only six degrees from the line, and where almost every thing becomes a prey to the insect, and that it is still as sound and bright as when it was first done, it will not be thought extravagant to surmise, that this specimen will retnin its pristine form and colours for years after the hand that stuffed it has mouldered into dust.

I huve shown this art to the naturalists in Brazil, Cayenne, Demerara, Oroonoque, and Rome, and to the royal cabinets of Turin and Florence. A severe accident prevented me from communicating it to the cabinet of Puris, aceording to my promise. A word or two more, and then we will conclude.

A little time and experience will enable you to produce a finished specimen. "Mox similis volucri, mox vera 
volucris." If your early performance should not corres- Pansanvixa pond with your expectations, do not?lyt that east you down. You cannot become an adept all at once. The poor hawk itself, which you have just been dissecting, waited to be fledged, before it durst rise on expanded pinion; and had parental aid, and frecuent praetice, ere it could soar with safety and ease beyond the sight of man.

Little more remains to be added, except that what has been penned down with regard to birds, may be applied, in some measure, to serpents, insects, and four-footed animals.

Should you find these instruetions too tedious, let the wish to give you every information plead in their defence. They might have been shorter; but Horace says, by labouring to be brief yon beeone obseure.

If, by their meaus, you should be enabled to procure specimens from forcign parts in better preservation than usual, so that the naturalist may have it in his power to give a more perfect description of them than has hitherto been the case; should they cause any unknown species to be brought into public view, and thus add a little more to the page of natural history, it will please me much. But should they, unfortunately, tend to cause a wauton expense of life ; should they tempt you to shoot the pretty songster warbling near your door, or destroy the mother, 
Preservivg as she is sitting on the nest to warm her little ones; or
Birds. Binds. kill the futher, as he is bringing a mouthful of food for their support;-Oh, then !-deep indeed will be the regret that I ever wrote them.

Adieu,

Charles Waterton. 


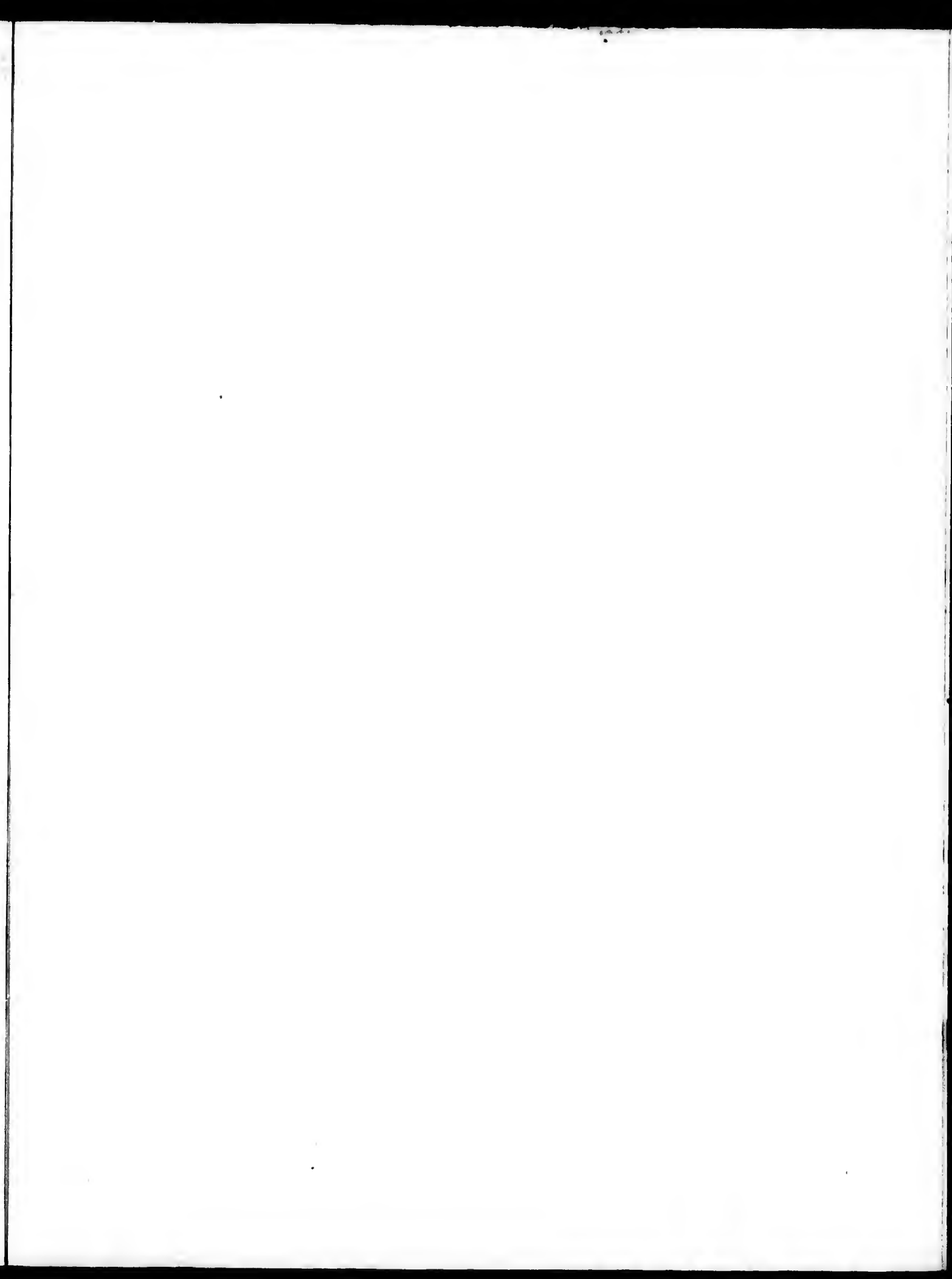




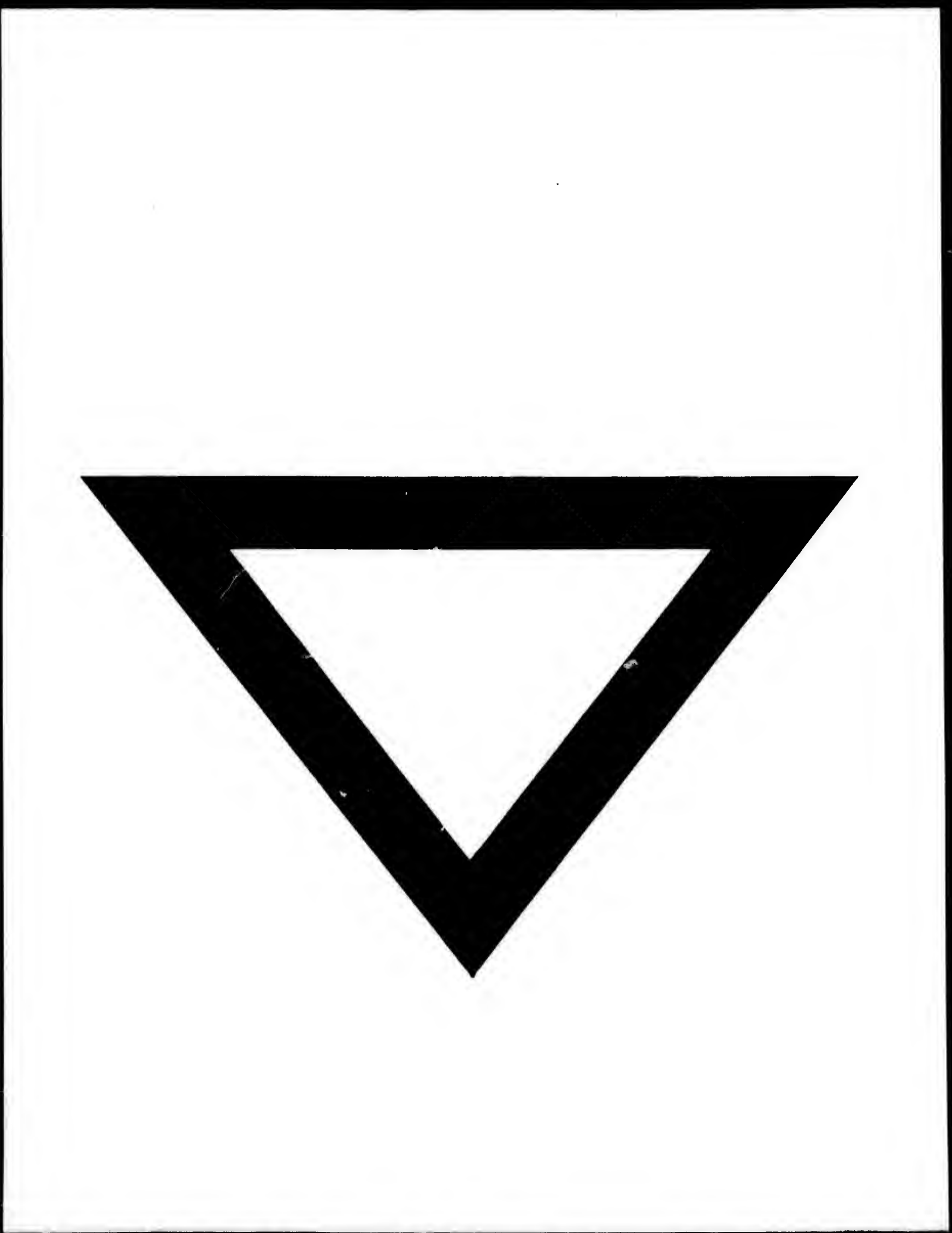

